\title{
Catalyst-Free Synthesis of Borylated Lactones from Esters via Electrophilic Oxyboration
}

\author{
Darius J. Faizi, Adena Issaian, Ashlee J. Davis, and Suzanne A. Blum* \\ Department of Chemistry, University of California, Irvine, California 92697-2025 \\ Email: blums@uci.edu
}

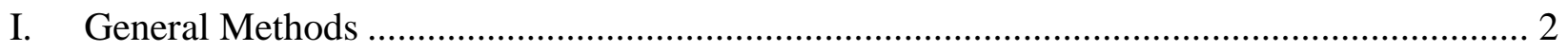

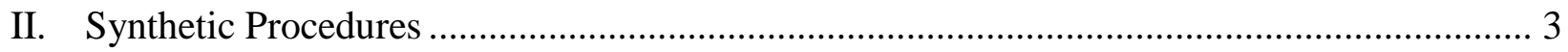

A. Preparation of Ester Substrates 1a-1p .................................................................. 3

B. Boron Electrophile Screen ………………………...................................................... 11

C. Reaction Condition Optimization...............................................................................12

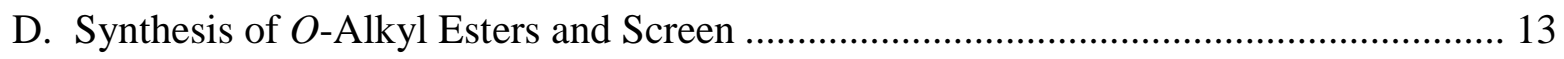

E. Synthesis and Isolation of Carboxyboration Products 3a-3p ....................................... 15

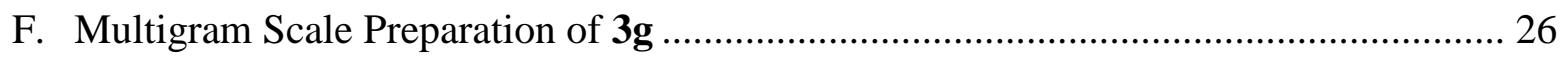

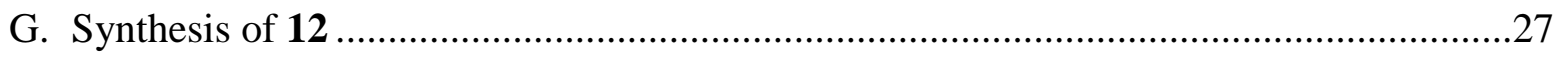

H. Suzuki Cross-Coupling of $\mathbf{3 g}$ to Generate 13 ................................................................

I. Synthesis of Borylated Isoxazole Product 15 ……..................................................... 28

J. Procedure for ${ }^{1} \mathrm{H}$ NMR observation of the rate of demethylation of methyl 2-

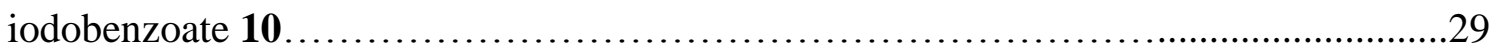

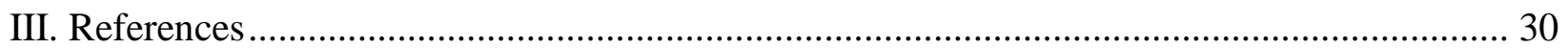

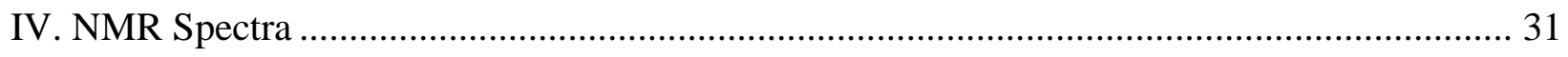




\section{General Methods}

All chemicals were used as received from commercial sources unless otherwise noted. Triethylamine, acetonitrile, toluene, tetrahydrofuran, and dichloromethane were purified by passage through an alumina column under argon pressure on a push-still solvent system. Toluene- $d_{8}$ was dried over $\mathrm{CaH}_{2}$, degassed using three freeze-pump-thaw cycles, and vacuum transferred prior to use. All manipulations were conducted using standard Schlenk techniques unless otherwise specified. Analytical thin layer chromatography (TLC) was performed using Merck $F_{250}$ plates. Plates were visualized under UV irradiation $(254 \mathrm{~nm})$ and/or using a basic aqueous solution of potassium permanganate. Flash chromatography was conducted using a Teledyne Isco Combiflash ${ }^{\circledR}$ Rf 200 Automated Flash Chromatography System, and Teledyne Isco Redisep ${ }^{\circledR} 35-70 \mu \mathrm{m}$ silica gel. All proton and carbon nuclear magnetic resonance $\left({ }^{1} \mathrm{H}\right.$ and ${ }^{13} \mathrm{C}$ NMR) spectra were recorded on a Bruker DRX-400 spectrometer, Bruker DRX-500 spectrometer outfitted with a cryoprobe, or a Bruker AVANCE-600 spectrometer. All boron nuclear magnetic resonance $\left({ }^{11} \mathrm{~B}\right.$ NMR) spectra were recorded on a Bruker AVANCE-600 spectrometer. All fluorine nuclear magnetic resonance $\left({ }^{19} \mathrm{~F}\right.$ NMR) spectra were recorded on a Bruker DRX-400. All chemical shifts $(\delta)$ are reported in parts per million $(\mathrm{ppm})$ downfield of tetramethylsilane, and referenced to the residual protiated solvent peak $\left(\delta=7.26 \mathrm{ppm}\right.$ for $\mathrm{CDCl}_{3}$, $\delta=2.08 \mathrm{ppm}$ for $d_{8}$-toluene, $\delta=2.05 \mathrm{ppm}$ for $d_{6}$-acetone, or $\delta=1.94 \mathrm{ppm}$ for $\mathrm{CD}_{3} \mathrm{CN}$ in ${ }^{1} \mathrm{H}$ NMR spectroscopy experiments; $\delta=77.2 \mathrm{ppm}$ for $\mathrm{CDCl}_{3}, \delta=29.8 \mathrm{ppm}$ for $d_{6}$-acetone, $\delta=20.4$ ppm for $d_{8}$-toluene, or $\delta=1.34 \mathrm{ppm}$ for $\mathrm{CD}_{3} \mathrm{CN}$ in ${ }^{13} \mathrm{C}$ NMR spectroscopy experiments). ${ }^{11} \mathrm{~B}$ and ${ }^{19} \mathrm{~F}$ NMR spectroscopy experiments are referenced to the absolute frequency of $0 \mathrm{ppm}$ in the ${ }^{1} \mathrm{H}$ dimension according to the Xi scale. High-resolution mass spectrometry data were obtained at the University of California, Irvine. 


\section{Synthetic Procedures}

\section{A. Preparation of Esters 1a-1p}<smiles>COC(=O)c1ccccc1I</smiles>

10

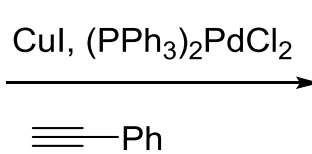

$\equiv \mathrm{Ph}$

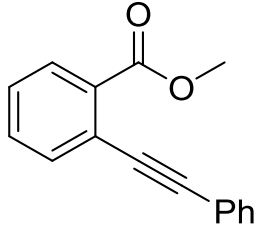

$1 \mathrm{a}$

Methyl 2-(phenylethynyl)benzoate (1a). A flask was charged with compound 10 (3.0 mL, 20. mmol, 1.0 equiv), $\left(\mathrm{PPh}_{3}\right)_{2} \mathrm{PdCl}_{2}$ ( $0.28 \mathrm{~g}, 0.40 \mathrm{mmol}, 0.020$ equiv), and $\mathrm{CuI}(0.15 \mathrm{~g}, 0.80 \mathrm{mmol}$, 0.040 equiv). The flask was then evacuated and refilled with $\mathrm{N}_{2}$ three times before $40 \mathrm{~mL}$ of acetonitrile and $\mathrm{Et}_{3} \mathrm{~N}(22 \mathrm{~mL}, 160 \mathrm{mmol}, 8.0$ equiv) were added. Phenylacetylene $(2.4 \mathrm{~mL}, 22$ mmol, 1.1 equiv) was then syringed into the reaction mixture which stirred for $18 \mathrm{~h}$ under dynamic $\mathrm{N}_{2}$. At this time, analysis by TLC (5\% EtOAc/hexanes) indicated full consumption of starting material. The reaction mixture was diluted with $200 \mathrm{~mL}$ EtOAc and washed with $\mathrm{NH}_{4} \mathrm{Cl}$ $(1 \times 45 \mathrm{~mL})$, water $(1 \times 45 \mathrm{~mL})$, brine $(1 \times 45 \mathrm{~mL})$, dried over $\mathrm{Na}_{2} \mathrm{SO}_{4}$, filtered, and concentrated in vacuo. The resulting oily residue was purified by column chromatography using an elution gradient from $100 \%$ hexanes to $5 \% \mathrm{EtOAc/hexanes.} \mathrm{Product-containing} \mathrm{fractions} \mathrm{were}$ combined and concentrated in vacuo, and volatiles were removed at c.a. 10 mTorr for $18 \mathrm{~h}$ to afford $1 \mathrm{a}$ as a light yellow oil $\left(4.2 \mathrm{~g}, 88 \%\right.$ yield). ${ }^{1} \mathrm{H} \mathrm{NMR}\left(\mathrm{CDCl}_{3}, 600 \mathrm{MHz}\right): \delta 7.98$ (d, $J=7.6$ $\mathrm{Hz}, 1 \mathrm{H}), 7.65(\mathrm{~d}, J=7.3 \mathrm{~Hz}, 1 \mathrm{H}), 7.59-7.57(\mathrm{~m}, 2 \mathrm{H}), 7.59-7.57(\mathrm{~m}, 1 \mathrm{H}), 7.40-7.35(\mathrm{~m}, 4 \mathrm{H}), 3.97$ $(\mathrm{s}, 3 \mathrm{H})$. This spectrum is in agreement with previously reported spectral data. ${ }^{1}$<smiles>COC(=O)c1ccccc1I</smiles>

10
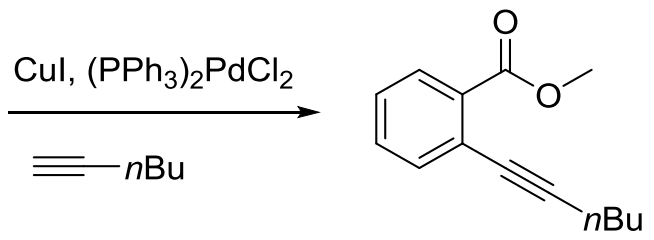

$1 b$

Methyl 2-(hex-1-yn-1-yl)benzoate (1b). A flask was charged with compound $\mathbf{1 0}(0.73 \mathrm{~mL}, 5.0$ mmol, 1.0 equiv), $\left(\mathrm{PPh}_{3}\right)_{2} \mathrm{PdCl}_{2}(0.070 \mathrm{~g}, 0.10 \mathrm{mmol}, 0.020$ equiv), and $\mathrm{CuI}(0.038 \mathrm{~g}, 0.20 \mathrm{mmol}$, 0.040 equiv). The flask was then evacuated and refilled with $\mathrm{N}_{2}$ three times before $10 \mathrm{~mL}$ of acetonitrile and $\mathrm{Et}_{3} \mathrm{~N}(5.6 \mathrm{~mL}, 40 . \mathrm{mmol}, 8.0$ equiv) were added. 1 -Hexyne $(0.63 \mathrm{~mL}, 5.5 \mathrm{mmol}$, 1.1 equiv) was then syringed into the reaction mixture, which then stirred for $18 \mathrm{~h}$ under dynamic $\mathrm{N}_{2}$. At this time, analysis by TLC (10\% EtOAc/hexanes) indicated full consumption of starting material. The reaction mixture was diluted with $100 \mathrm{~mL}$ EtOAc and washed with $\mathrm{NH}_{4} \mathrm{Cl}(1 \times 25$ $\mathrm{mL})$, water $(1 \times 25 \mathrm{~mL})$, brine $(1 \times 25 \mathrm{~mL})$, dried over $\mathrm{Na}_{2} \mathrm{SO}_{4}$, filtered, and concentrated in vacuo. The resulting oily residue was purified by column chromatography using an elution gradient from $100 \%$ hexanes to $10 \%$ EtOAc/hexanes. Product-containing fractions were combined and concentrated in vacuo, and volatiles were removed at c.a. $10 \mathrm{mTorr}$ for $18 \mathrm{~h}$ to afford $\mathbf{1 b}$ as a light yellow oil $\left(0.80 \mathrm{~g}, 74 \%\right.$ yield). ${ }^{1} \mathrm{H} \mathrm{NMR}\left(\mathrm{CDCl}_{3}, 600 \mathrm{MHz}\right): \delta 7.88(\mathrm{~d} J=7.9$ $\mathrm{Hz}, 1 \mathrm{H}), 7.51(\mathrm{~d}, J=7.8 \mathrm{~Hz}, 1 \mathrm{H}), 7.41(\mathrm{td}, J=7.6 \mathrm{~Hz}, 1 \mathrm{H}), 7.30(\mathrm{t}, J=7.6 \mathrm{~Hz}, 1 \mathrm{H}), 3.91(\mathrm{~s}, 3 \mathrm{H})$, 
$2.48(\mathrm{t}, J=7.1 \mathrm{~Hz}, 2 \mathrm{H}), 1.64-1.60(\mathrm{~m}, 2 \mathrm{H}), 1.54-1.48(\mathrm{~m}, 2 \mathrm{H}), 0.96(\mathrm{t}, J=7.3 \mathrm{~Hz}, 3 \mathrm{H})$. This spectrum is in agreement with previously reported spectral data. ${ }^{2}$

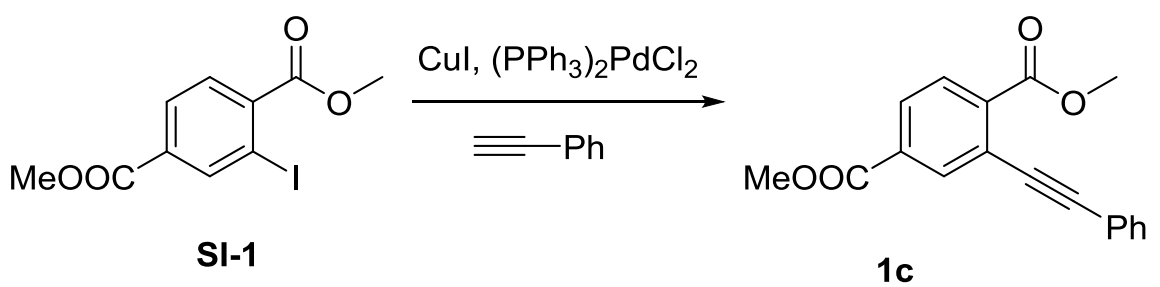

Methyl 4-acetoxy-2-(phenylethynyl)benzoate (1c). A flask was charged with $\left(\mathrm{PPh}_{3}\right)_{2} \mathrm{PdCl}_{2}$ ( $0.022 \mathrm{~g}, 0.030 \mathrm{mmol}, 0.020$ equiv), and $\mathrm{CuI}(0.011 \mathrm{~g}, 0.060 \mathrm{mmol}, 0.040$ equiv). The flask was then evacuated and refilled with $\mathrm{N}_{2}$ three times before $4 \mathrm{~mL}$ of $\mathrm{Et}_{3} \mathrm{~N}$ were added. The reaction mixture was then sparged for 5 minutes before compound SI-1 ( $0.50 \mathrm{~g}, 1.6 \mathrm{mmol}, 1.0$ equiv) was added. Phenylacetylene $(0.21 \mathrm{~mL}, 1.9 \mathrm{mmol}, 1.2$ equiv) was then added via syringe, and the reaction mixture was heated to $55{ }^{\circ} \mathrm{C}$ in an oil bath and stirred for $16 \mathrm{~h}$ under dynamic $\mathrm{N}_{2}$. At this time, analysis by TLC (20\% EtOAc/hexanes) indicated full consumption of starting material. The reaction mixture was diluted with $100 \mathrm{~mL}$ DCM and washed with water $(1 \times 25 \mathrm{~mL})$, brine $(1 \times 25 \mathrm{~mL})$, dried over $\mathrm{Na}_{2} \mathrm{SO}_{4}$, filtered, and concentrated in vacuo. The resulting oily residue was purified by column chromatography using an elution gradient from $100 \%$ hexanes to $20 \%$ EtOAc/hexanes. Product-containing fractions were combined and concentrated in vacuo, and volatiles were removed at c.a. 10 mTorr for $18 \mathrm{~h}$ to afford 1c as a yellow solid $(0.44 \mathrm{~g}, 95 \%$ yield). ${ }^{1} \mathrm{H} \mathrm{NMR}\left(\mathrm{CDCl}_{3}, 600 \mathrm{MHz}\right): \delta 8.26(\mathrm{~s}, 1 \mathrm{H}), 8.00-7.96(\mathrm{~m}, 2 \mathrm{H}), 7.57-7.56(\mathrm{~m}, 2 \mathrm{H}), 7.35-$ $7.34(\mathrm{~m}, 3 \mathrm{H}), 3.96(\mathrm{~s}, 3 \mathrm{H}), 3.92(\mathrm{~s}, 3 \mathrm{H})$. This spectrum is in agreement with previously reported spectral data. $^{2}$

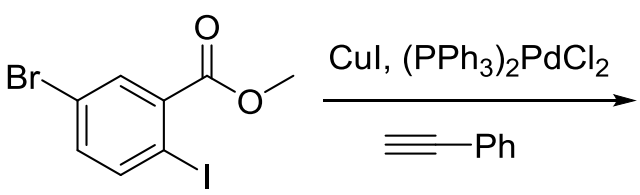

SI-2

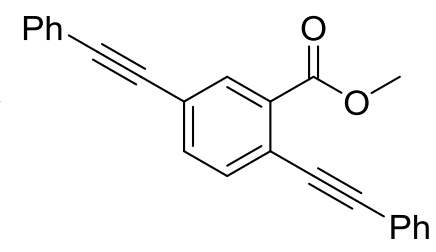

$1 d$

Methyl 2,5-bis(phenylethynyl)benzoate (1d) A flask was charged with $\left(\mathrm{PPh}_{3}\right)_{2} \mathrm{PdCl}_{2}(0.017 \mathrm{~g}$, $0.24 \mathrm{mmol}, 0.040$ equiv), and $\mathrm{CuI}(0.016 \mathrm{~g}, 0.12 \mathrm{mmol}, 0.020$ equiv). The flask was then evacuated and refilled with $\mathrm{N}_{2}$ three times before $4 \mathrm{~mL}$ of $\mathrm{Et}_{3} \mathrm{~N}$ were added. The reaction mixture was then sparged for $5 \mathrm{~min}$ before SI-2 (2.00 g, $5.87 \mathrm{mmol}, 1.00$ equiv) was added. Phenylacetylene $(0.70 \mathrm{~mL}, 6.5 \mathrm{mmol}, 1.1$ equiv) was then added via syringe, and the reaction mixture was heated to $55{ }^{\circ} \mathrm{C}$ in an oil bath and stirred for $16 \mathrm{~h}$ under dynamic $\mathrm{N}_{2}$. At this time, analysis by TLC (5\% EtOAc/hexanes) indicated full consumption of starting material. The reaction mixture was diluted with $100 \mathrm{~mL} \mathrm{DCM}$ and washed with water $(1 \times 25 \mathrm{~mL})$, brine $(1 \times$ $25 \mathrm{~mL}$ ), dried over $\mathrm{Na}_{2} \mathrm{SO}_{4}$, filtered, and concentrated in vacuo. The resulting oily residue was purified by column chromatography using an elution gradient from 100\% hexanes to 5\% EtOAc/hexanes. Product-containing fractions were combined and concentrated in vacuo, and volatiles were removed at c.a. 10 mTorr for $18 \mathrm{~h}$ to afford the minor product $\mathbf{1 d}$ as a white solid 
(0.17 g, $11 \%$ yield). ${ }^{1} \mathrm{H}$ NMR $\left(\mathrm{CDCl}_{3}, 600 \mathrm{MHz}\right): \delta 8.15(\mathrm{~s}, 1 \mathrm{H}), 7.60-7.54(\mathrm{~m}, 4 \mathrm{H}), 7.38-7.36$ $(\mathrm{m}, 6 \mathrm{H}), 4.0(\mathrm{~s}, 3 \mathrm{H})$. This spectrum is in agreement with previously reported spectral data. ${ }^{3}$

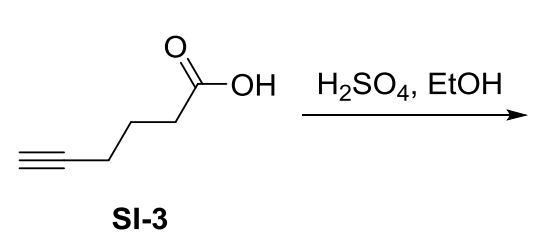

SI-3

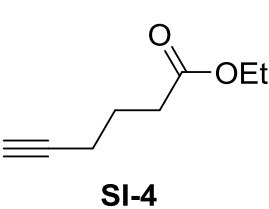

SI-4

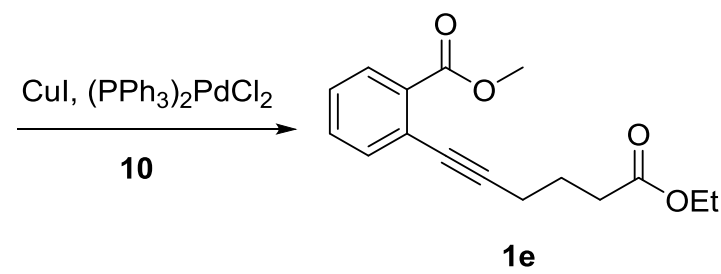

1e

Ethyl hex-5-ynoate (SI-4) was prepared according to a literature procedure ${ }^{4}$ in $87 \%$ yield. ${ }^{1} \mathrm{H}$ NMR $\left(\mathrm{CDCl}_{3}, 600 \mathrm{MHz}\right) \delta 4.14(\mathrm{q}, J=7.1 \mathrm{~Hz}, 2 \mathrm{H}), 2.44(\mathrm{t}, J=7.4 \mathrm{~Hz}, 2 \mathrm{H}), 2.27(\mathrm{dt}, J=7.0$, $2.6 \mathrm{~Hz}, 2 \mathrm{H}$ ), 1.97 (t, $J=2.6 \mathrm{~Hz}, 1 \mathrm{H}), 1.85$ (quin, $J=7.2 \mathrm{~Hz}, 1 \mathrm{H}), 1.26(\mathrm{t}, J=7.2 \mathrm{~Hz}, 3 \mathrm{H}$ ). This spectrum is in agreement with previously reported spectral data.

Methyl 2-(6-ethoxy-6-oxohex-1-yn-1-yl)benzoate (1e). A flask was charged with compound 10 ( $0.50 \mathrm{~g}, 1.8 \mathrm{mmol}, 1.0$ equiv), $\left(\mathrm{PPh}_{3}\right)_{2} \mathrm{PdCl}_{2}(0.038 \mathrm{~g}, 0.054 \mathrm{mmol}, 0.030$ equiv), and $\mathrm{CuI}(0.031$ $\mathrm{g}, 0.16 \mathrm{mmol}, 0.090$ equiv). The flask was then evacuated and refilled with $\mathrm{N}_{2}$ three times before $4 \mathrm{~mL}$ of acetonitrile and $\mathrm{Et}_{3} \mathrm{~N}(0.25 \mathrm{~mL}, 1.8 \mathrm{mmol}, 8.0$ equiv) were added. Compound SI-4 (0.38 $\mathrm{g}, 2.7 \mathrm{mmol}, 1.5$ equiv) was then syringed into the reaction mixture which stirred for $18 \mathrm{~h}$ under dynamic $\mathrm{N}_{2}$. At this time, analysis by TLC (10\% EtOAc/hexanes) indicated full consumption of starting material. The reaction mixture was diluted with $125 \mathrm{~mL}$ EtOAc and washed with $\mathrm{NH}_{4} \mathrm{Cl}$ $(1 \times 45 \mathrm{~mL})$, water $(1 \times 45 \mathrm{~mL})$, brine $(1 \times 45 \mathrm{~mL})$, dried over $\mathrm{Na}_{2} \mathrm{SO}_{4}$, filtered, and concentrated in vacuo. The resulting oily residue was purified by column chromatography using an elution gradient from $100 \%$ hexanes to $10 \%$ EtOAc/hexanes. Product-containing fractions were combined and concentrated in vacuo, and volatiles were removed at c.a. $10 \mathrm{mTorr}$ for $18 \mathrm{~h}$ to afford $1 \mathrm{e}$ as a light yellow oil $(0.42 \mathrm{~g}, 80 \%$ yield $)$.

${ }^{1} \mathrm{H}$ NMR $\left(\mathrm{CDCl}_{3}, 600 \mathrm{MHz}\right): \delta 7.88(\mathrm{~d}, J=7.8 \mathrm{~Hz}, 1 \mathrm{H}), 7.50(\mathrm{~d}, J=7.6 \mathrm{~Hz}, 1 \mathrm{H}), 7.42(\mathrm{t}, J=7.3$ $\mathrm{Hz}, 1 \mathrm{H}), 7.31(\mathrm{t}, J=7.3 \mathrm{~Hz}, 1 \mathrm{H}), 4.13(\mathrm{q}, J=7.2 \mathrm{~Hz}, 2 \mathrm{H}), 3.91(\mathrm{~s}, 3 \mathrm{H}), 2.56-2.52(\mathrm{~m}, 4 \mathrm{H}), 1.95$ (quin, $J=7.2 \mathrm{~Hz}, 2 \mathrm{H}), 1.25(\mathrm{t}, J=7.1 \mathrm{~Hz}, 3 \mathrm{H})$.

${ }^{13} \mathrm{C}$ NMR $\left(\mathrm{CDCl}_{3}, 125 \mathrm{MHz}\right): \delta 173.3,166.9,134.3,132.0,131.6,130.2,127.4,124.2,94.4$, 80.1, 60.4, 52.2, 33.2, 23.9, 23.5, 18.7, 14.3 .

HRMS (ESI+): Calculated for $\mathrm{C}_{16} \mathrm{H}_{18} \mathrm{O}_{4} \mathrm{Na}\left([\mathrm{M}+\mathrm{Na}]^{+}\right), 297.1103$; found 297.1096.<smiles>COC(=O)c1ccccc1I</smiles>

10

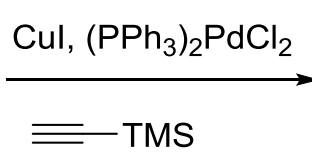

$\equiv$ TMS<smiles>COC(=O)c1ccccc1C#CC#N</smiles>

SI-5

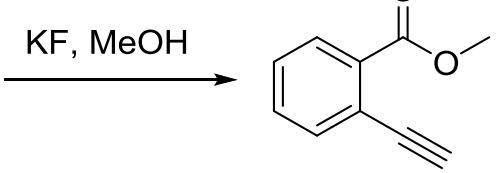

$1 \mathbf{f}$

Methyl 2-((trimethylsilyl)ethynyl)benzoate (SI-5). A flask was charged with compound $\mathbf{1 0}$ (5.2 $\mathrm{mL}, 38 \mathrm{mmol}, 1.0$ equiv), $\left(\mathrm{PPh}_{3}\right)_{2} \mathrm{PdCl}_{2}(0.53 \mathrm{~g}, 1.5 \mathrm{mmol}, 0.020$ equiv), and $\mathrm{CuI}(0.29 \mathrm{~g}$, $1.5 \mathrm{mmol}, 0.040$ equiv). The flask was then evacuated and refilled with $\mathrm{N}_{2}$ three times before 76 $\mathrm{mL}$ of acetonitrile and $\mathrm{Et}_{3} \mathrm{~N}$ ( $40 \mathrm{~mL}, 300 \mathrm{mmol}, 8$ equiv) were added. Trimethylsilyl acetylene 
(5.9 mL, $42 \mathrm{mmol}, 1.1$ equiv) was then syringed into the reaction mixture which stirred for $18 \mathrm{~h}$ under dynamic $\mathrm{N}_{2}$. At this time, analysis by TLC (5\% EtOAc/hexanes) indicated full consumption of starting material. The reaction mixture was diluted with $300 \mathrm{~mL} \mathrm{Et}_{2} \mathrm{O}$ and washed with $\mathrm{NH}_{4} \mathrm{Cl}(1 \times 50 \mathrm{~mL})$, water $(1 \times 50 \mathrm{~mL})$, brine $(1 \times 50 \mathrm{~mL})$, dried over $\mathrm{Na}_{2} \mathrm{SO}_{4}$, filtered, and concentrated in vacuo. The resulting oily residue was purified by column chromatography using an elution gradient from $100 \%$ hexanes to 5\% EtOAc/hexanes. Productcontaining fractions were combined and concentrated in vacuo, and volatiles were removed at c.a. $10 \mathrm{mTorr}$ for $18 \mathrm{~h}$ to afford SI-5 as a yellow oil (7.0 g, 79\% yield). ${ }^{1} \mathrm{H} \mathrm{NMR}\left(\mathrm{CDCl}_{3}, 600\right.$ MHz): $\delta 7.90(\operatorname{app~d}, J=7.6 \mathrm{~Hz}, 1 \mathrm{H}), 7.58(\operatorname{app~d}, J=7.5 \mathrm{~Hz}, 1 \mathrm{H}), 7.44(\mathrm{td}, J=7.6,0.8 \mathrm{~Hz}$, $1 \mathrm{H}), 7.36(\operatorname{app} \mathrm{t}, J=7.6 \mathrm{~Hz}, 1 \mathrm{H}), 3.92(\mathrm{~s}, 3 \mathrm{H}), 0.27(\mathrm{~s}, 9 \mathrm{H})$. This spectrum is in agreement with previously reported spectral data. ${ }^{5}$

Methyl 2-ethynylbenzoate (1f). A flask was charged with compound SI-5 (2.9 g, 13 mmol, 1.0 equiv), $63 \mathrm{~mL}$ methanol, and potassium fluoride ( $2.6 \mathrm{~g}, 44 \mathrm{mmol}, 3.5$ equiv). The flask was then sealed with a ground glass stopper and heated to $40{ }^{\circ} \mathrm{C}$ while stirring for $3 \mathrm{~h}$. At this time, analysis by TLC (10\% EtOAc/hexanes) indicated full consumption of starting material. The reaction mixture was diluted with $200 \mathrm{~mL} \mathrm{Et}_{2} \mathrm{O}$ and washed with water $(4 \times 50 \mathrm{~mL})$, brine $(1 \times$ $50 \mathrm{~mL}$ ), dried over $\mathrm{Na}_{2} \mathrm{SO}_{4}$, filtered, and concentrated in vacuo at $\sim 10$ Torr and $25^{\circ} \mathrm{C}$ [warning: product is volatile], yielding $\mathbf{1}$ as a dark yellow/red liquid $\left(1.7 \mathrm{~g}, 84 \%\right.$ yield). ${ }^{1} \mathrm{H} \mathrm{NMR}\left(\mathrm{CDCl}_{3}\right.$, $600 \mathrm{MHz}): \delta 7.94(\mathrm{~d}, J=7.8 \mathrm{~Hz}, 1 \mathrm{H}), 7.62(\mathrm{~d}, J=7.7 \mathrm{~Hz}, 1 \mathrm{H}), 7.47(\mathrm{t}, J=7.6 \mathrm{~Hz}, 1 \mathrm{H}), 7.40(\mathrm{t}, J$ $=7.6 \mathrm{~Hz}, 1 \mathrm{H}), 3.93(\mathrm{~s}, 3 \mathrm{H}), 3.40(\mathrm{~s}, 1 \mathrm{H})$. This spectrum is in agreement with previously reported spectral data. ${ }^{6}$

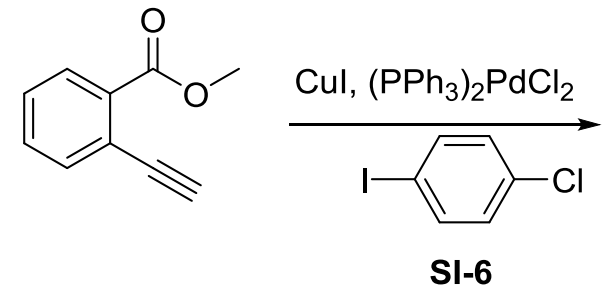

$1 f$

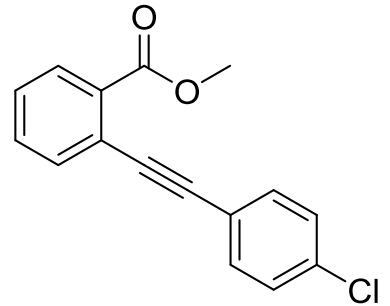

$1 \mathrm{~g}$

Methyl 2-((4-chlorophenyl)ethynyl)benzoate (1g). A flask was charged with compound SI-6 (0.36 g, $1.5 \mathrm{mmol}, 1.0$ equiv), $\left(\mathrm{PPh}_{3}\right)_{2} \mathrm{PdCl}_{2}(0.021 \mathrm{~g}, 0.030 \mathrm{mmol}, 0.020$ equiv), and $\mathrm{CuI}$ ( 0.012 $\mathrm{g}, 0.060 \mathrm{mmol}, 0.040$ equiv). The flask was then evacuated and refilled with $\mathrm{N}_{2}$ three times before $3 \mathrm{~mL}$ of acetonitrile and $\mathrm{Et}_{3} \mathrm{~N}(1.7 \mathrm{~mL}, 12 \mathrm{mmol}, 8.0$ equiv) were added. Compound $\mathbf{1 f}$ $(0.27 \mathrm{~g}, 1.7 \mathrm{mmol}, 1.1$ equiv) was then syringed into the reaction mixture which stirred for $18 \mathrm{~h}$ under dynamic $\mathrm{N}_{2}$. At this time, analysis by TLC (10\% EtOAc/hexanes) indicated full consumption of starting material. The reaction mixture was diluted with $150 \mathrm{~mL} \mathrm{Et}_{2} \mathrm{O}$ and washed with $\mathrm{NH}_{4} \mathrm{Cl}(1 \times 40 \mathrm{~mL})$, water $(1 \times 40 \mathrm{~mL})$, brine $(1 \times 40 \mathrm{~mL})$, dried over $\mathrm{Na}_{2} \mathrm{SO}_{4}$, filtered, and concentrated in vacuo. The resulting oily residue was purified by column chromatography using an elution gradient from $100 \%$ hexanes to $10 \%$ EtOAc/hexanes. Productcontaining fractions were combined and concentrated in vacuo, and volatiles were removed at c.a. $10 \mathrm{mTorr}$ for $18 \mathrm{~h}$ to afford $\mathbf{1 g}$ as a light yellow liquid that solidified upon standing at room temperature (0.34 g, 84\% yield). ${ }^{1} \mathrm{H}$ NMR $\left(\mathrm{CDCl}_{3}, 500 \mathrm{MHz}\right): \delta 7.99(\mathrm{dd}, J=7.9,1.0 \mathrm{~Hz}, 1 \mathrm{H})$, 
$7.64(\mathrm{dd}, J=7.7,0.9 \mathrm{~Hz}, 1 \mathrm{H}), 7.52-7.49(\mathrm{~m}, 3 \mathrm{H}), 7.40(\mathrm{td}, J=7.7,1.3 \mathrm{~Hz}, 1 \mathrm{H}), 7.35-7.33(\mathrm{~m}$, $2 \mathrm{H}), 3.96(\mathrm{~s}, 3 \mathrm{H})$. This spectrum is in agreement with previously reported spectral data. ${ }^{7}$

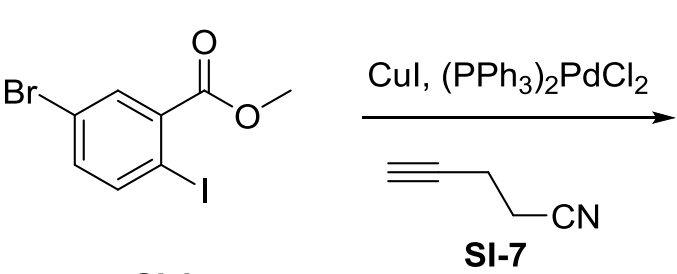

SI-2

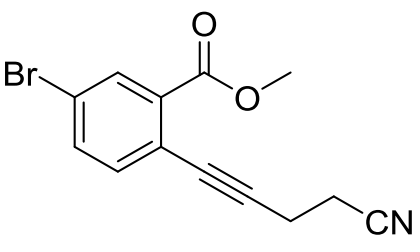

$1 \mathrm{~h}$

Methyl 5-bromo-2-(4-cyanobut-1-yn-1-yl)benzoate (1h). A flask was charged with compound SI-2 (0.34 g, $1.0 \mathrm{mmol}, 1.0$ equiv), $\left(\mathrm{PPh}_{3}\right)_{2} \mathrm{PdCl}_{2}(0.014 \mathrm{~g}, 0.020 \mathrm{mmol}, 0.020$ equiv), and $\mathrm{CuI}$ (0.008 g, $0.04 \mathrm{mmol}, 0.04$ equiv). The flask was then evacuated and refilled with $\mathrm{N}_{2}$ three times before $2 \mathrm{~mL}$ of acetonitrile and $\mathrm{Et}_{3} \mathrm{~N}$ ( $1.1 \mathrm{~mL}, 8.0 \mathrm{mmol}, 8.0$ equiv) were added. Compound SI-7 $(0.10 \mathrm{~mL}, 1.1 \mathrm{mmol}, 1.1$ equiv) was then syringed into the reaction mixture which stirred for 18 $\mathrm{h}$ under dynamic $\mathrm{N}_{2}$. At this time, analysis by TLC (20\% EtOAc/hexanes) indicated full consumption of starting material. The reaction mixture was diluted with $150 \mathrm{~mL}$ EtOAc and washed with $\mathrm{NH}_{4} \mathrm{Cl}(1 \times 25 \mathrm{~mL})$, water $(1 \times 25 \mathrm{~mL})$, brine $(1 \times 25 \mathrm{~mL})$, dried over $\mathrm{Na}_{2} \mathrm{SO}_{4}$, filtered, and concentrated in vacuo. The resulting oily residue was purified by column chromatography using an elution gradient from $100 \%$ hexanes to $20 \%$ EtOAc/hexanes. Productcontaining fractions were combined and concentrated in vacuo, and volatiles were removed at c.a. $10 \mathrm{mTorr}$ for $18 \mathrm{~h}$ to afford $\mathbf{1 h}$ as a light yellow solid $(0.25 \mathrm{~g}, 86 \%$ yield $)$.

${ }^{1} \mathrm{H}$ NMR $\left(\mathrm{CDCl}_{3}, 500 \mathrm{MHz}\right): \delta 8.06(\mathrm{~s}, 1 \mathrm{H}), 7.57(\mathrm{~d}, J=8.3 \mathrm{~Hz}, 1 \mathrm{H}), 7.40(\mathrm{~d}, J=8.3 \mathrm{~Hz}, 1 \mathrm{H})$, $3.92(\mathrm{~s}, 3 \mathrm{H}), 2.84(\mathrm{t}, J=7.2 \mathrm{~Hz}, 2 \mathrm{H}), 2.69(\mathrm{t}, J=7.2 \mathrm{~Hz}, 2 \mathrm{H})$.

${ }^{13} \mathrm{C} \mathrm{NMR}\left(\mathrm{CDCl}_{3}, 125 \mathrm{MHz}\right): \delta 165.2,135.7,134.9,133.41,133.38,122.3,122.0,118.3,91.7$, 81.0, 52.6, 17.5, 17.2.

HRMS (CI+): Calculated for $\mathrm{C}_{13} \mathrm{H}_{14} \mathrm{BrN}_{2} \mathrm{O}_{2}\left(\left[\mathrm{M}+\mathrm{NH}_{4}\right]^{+}\right)$, 309.0239; found 309.0230.<smiles>COC(=O)c1ccccc1I</smiles>

10

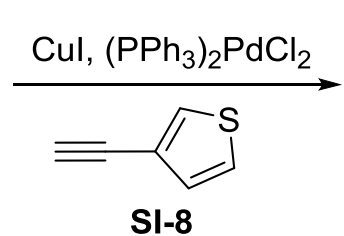

SI-8

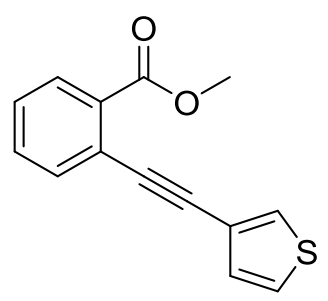

$1 \mathbf{i}$

Methyl 2-(thiophen-3-ylethynyl)benzoate (1i). A flask was charged with compound $10(0.22$ $\mathrm{mL}, 1.5 \mathrm{mmol}, 1.0$ equiv), $\left(\mathrm{PPh}_{3}\right)_{2} \mathrm{PdCl}_{2}(0.021 \mathrm{~g}, 0.030 \mathrm{mmol}, 0.020$ equiv), and $\mathrm{CuI}(0.011 \mathrm{~g}$, $0.060 \mathrm{mmol}, 0.040$ equiv). The flask was then evacuated and refilled with $\mathrm{N}_{2}$ three times before $3 \mathrm{~mL}$ of acetonitrile and $\mathrm{Et}_{3} \mathrm{~N}(1.7 \mathrm{~mL}, 12 \mathrm{mmol}, 8.0$ equiv) were added. Compound SI-8 (0.17 $\mathrm{mL}, 1.7 \mathrm{mmol}, 1.1$ equiv) was then syringed into the reaction mixture, which was then stirred for $18 \mathrm{~h}$ under dynamic $\mathrm{N}_{2}$. At this time, analysis by TLC (20\% EtOAc/hexanes) indicated full consumption of starting material. The reaction mixture was diluted with $150 \mathrm{~mL}$ EtOAc and 
washed with $\mathrm{NH}_{4} \mathrm{Cl}(1 \times 25 \mathrm{~mL})$, water $(1 \times 25 \mathrm{~mL})$, brine $(1 \times 25 \mathrm{~mL})$, dried over $\mathrm{Na}_{2} \mathrm{SO}_{4}$, filtered, and concentrated in vacuo. The resulting oily residue was purified by column chromatography using an elution gradient from $100 \%$ hexanes to $20 \%$ EtOAc/hexanes. Productcontaining fractions were combined and concentrated in vacuo, and volatiles were removed at c.a. $10 \mathrm{mTorr}$ for $18 \mathrm{~h}$ to afford $\mathbf{1 i}$ as a light yellow solid $(0.37 \mathrm{~g}, 78 \%$ yield $)$.

${ }^{1} \mathrm{H}$ NMR $\left(\mathrm{CDCl}_{3}, 600 \mathrm{MHz}\right): \delta 7.95(\mathrm{~d}, J=7.8 \mathrm{~Hz}, 1 \mathrm{H}), 7.61(\mathrm{~d}, J=7.6 \mathrm{~Hz}, 1 \mathrm{H}), 7.58-7.56(\mathrm{~m}$, $1 \mathrm{H}), 7.45(\mathrm{td}, J=7.6,1.3 \mathrm{~Hz}, 1 \mathrm{H}), 7.34(\mathrm{td}, J=7.6,1.3 \mathrm{~Hz}, 1 \mathrm{H}), 7.29$ (dd, $J=4.9,3.0 \mathrm{~Hz}, 1 \mathrm{H})$, 7.23 (app. d, $J=5.0 \mathrm{~Hz}, 1 \mathrm{H}), 3.93$ (s, 3H).

${ }^{13} \mathrm{C} \mathrm{NMR}\left(\mathrm{CDCl}_{3}, 125 \mathrm{MHz}\right): \delta 166.7,134.0,131.8,131.7,130.5,130.0,129.2,127.9,125.5$, $123.8,122.5,89.7,87.9,52.2$.

HRMS (CI+): Calculated for $\mathrm{C}_{14} \mathrm{H}_{10} \mathrm{SO}_{2}\left([\mathrm{M}]^{+}\right), 242.0401$; found 242.0390.<smiles>COC(=O)c1ccccc1I</smiles>

10

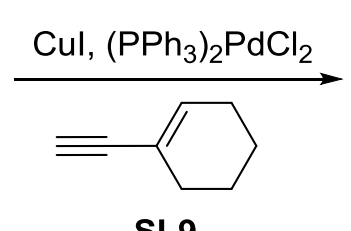

SI-9

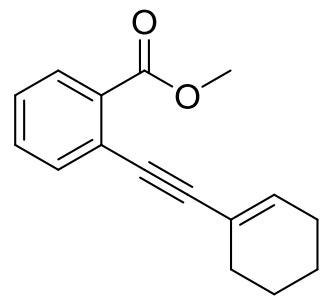

1j

methyl 2-(cyclohex-1-en-1-ylethynyl)benzoate (1j). A flask was charged with compound 10 (0.22 mL, $1.5 \mathrm{mmol}, 1.0$ equiv), $\left(\mathrm{PPh}_{3}\right)_{2} \mathrm{PdCl}_{2}(0.021 \mathrm{~g}, 0.030 \mathrm{mmol}, 0.020$ equiv), and $\mathrm{CuI}$ $\left(0.011 \mathrm{~g}, 0.060 \mathrm{mmol}, 0.040\right.$ equiv). The flask was then evacuated and refilled with $\mathrm{N}_{2}$ three times before $3 \mathrm{~mL}$ of acetonitrile and $\mathrm{Et}_{3} \mathrm{~N}(1.7 \mathrm{~mL}, 12 \mathrm{mmol}, 8.0$ equiv) were added. Compound SI-9 $(0.20 \mathrm{~mL}, 1.7 \mathrm{mmol}, 1.1$ equiv) was then syringed into the reaction mixture which stirred for $18 \mathrm{~h}$ under dynamic $\mathrm{N}_{2}$. At this time, analysis by TLC (10\% EtOAc/hexanes) indicated full consumption of starting material. The reaction mixture was diluted with $150 \mathrm{~mL} \mathrm{Et}{ }_{2} \mathrm{O}$ and washed with $\mathrm{NH}_{4} \mathrm{Cl}(1 \times 25 \mathrm{~mL})$, water $(1 \times 25 \mathrm{~mL})$, brine $(1 \times 25 \mathrm{~mL})$, dried over $\mathrm{Na}_{2} \mathrm{SO}_{4}$, filtered, and concentrated in vacuo. The resulting oily residue was purified by column chromatography using an elution gradient from 100\% hexanes to 5\% EtOAc/hexanes. Productcontaining fractions were combined and concentrated in vacuo, and volatiles were removed at c.a. $10 \mathrm{mTorr}$ for $18 \mathrm{~h}$ to afford $\mathbf{1 j}$ as a yellow oil $(0.35 \mathrm{~g}, 96 \%$ yield $) .{ }^{1} \mathrm{H}$ NMR $\left(\mathrm{CDCl}_{3}, 600\right.$ MHz): $\delta 7.92(\mathrm{dd}, J=7.9,1.1 \mathrm{~Hz}, 1 \mathrm{H}), 7.52(\mathrm{dd}, J=7.7,1.0 \mathrm{~Hz}, 1 \mathrm{H}), 7.43(\mathrm{td}, J=7.6,1.3 \mathrm{~Hz}$, $1 \mathrm{H}), 7.31(\mathrm{td}, J=7.7,1.2 \mathrm{~Hz}, 1 \mathrm{H}), 6.28-6.26(\mathrm{~m}, 1 \mathrm{H}), 3.92(\mathrm{~s}, 3 \mathrm{H}), 2.28-2.25(\mathrm{~m}, 2 \mathrm{H}), 2.18-$ $2.14(\mathrm{~m}, 2 \mathrm{H}), 1.71-1.67(\mathrm{~m}, 2 \mathrm{H}), 1.64-1.61(\mathrm{~m}, 2 \mathrm{H})$. This spectrum is in agreement with previously reported spectral data. ${ }^{8}$
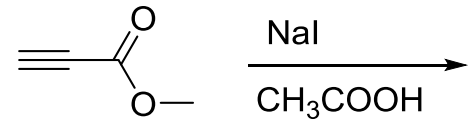

SI-10

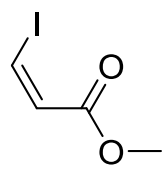

SI-11

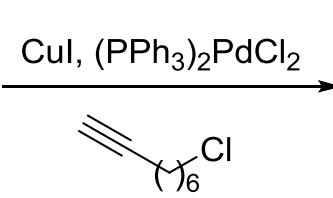

SI-12

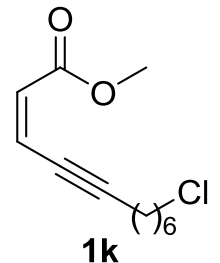

$1 \mathrm{k}$ 
Methyl (Z)-3-iodoacrylate (SI-11) was prepared according to a literature procedure ${ }^{9}$ in $75 \%$ yield. ${ }^{1} \mathrm{H}$ NMR $\left(\mathrm{CDCl}_{3}, 600 \mathrm{MHz}\right): \delta 7.47(\mathrm{~d}, J=8.9 \mathrm{~Hz}, 1 \mathrm{H}), 6.91(\mathrm{~d}, J=9.0 \mathrm{~Hz}, 1 \mathrm{H}), 3.79(\mathrm{~s}$, $3 \mathrm{H})$. This spectrum is in agreement with previously reported spectral data.

Methyl (Z)-11-chloroundec-2-en-4-ynoate (1k). This procedure was performed in a $\mathrm{N}_{2}$-filled glove box. A $20 \mathrm{~mL}$ vial was charged with compound SI-11 (0.42 g, $2.0 \mathrm{mmol}, 1.0$ equiv), $\left(\mathrm{PPh}_{3}\right)_{2} \mathrm{PdCl}_{2}$ ( $0.105 \mathrm{mg}, 0.150 \mathrm{mmol}, 0.0750$ equiv), $\mathrm{CuI}$ (0.014 g, $0.074 \mathrm{mmol}, 0.037$ equiv), and a stir bar. $5 \mathrm{~mL}$ of $\mathrm{Et}_{3} \mathrm{~N}$ were added. Compound $\mathbf{S I - 1 2}(0.37 \mathrm{~mL}, 2.4 \mathrm{mmol}, 1.2$ equiv) was then syringed into the reaction mixture, which was then heated to $50{ }^{\circ} \mathrm{C}$ and stirred for $18 \mathrm{~h}$. At this time, analysis by TLC ( $10 \%$ EtOAc/hexanes) indicated full consumption of starting material. The reaction mixture was diluted with $150 \mathrm{~mL}$ EtOAc and washed with $\mathrm{NH}_{4} \mathrm{Cl}(1 \times 25 \mathrm{~mL})$, water $(1 \times 25 \mathrm{~mL})$, brine $(1 \times 25 \mathrm{~mL})$, dried over $\mathrm{Na}_{2} \mathrm{SO}_{4}$, filtered, and concentrated in vacuo. The resulting oily residue was purified by column chromatography using an elution gradient from $100 \%$ hexanes to $10 \%$ EtOAc/hexanes. Product-containing fractions were combined and concentrated in vacuo, and volatiles were removed at c.a. 10 mTorr for $18 \mathrm{~h}$ to afford $\mathbf{1 k}$ as a viscous yellow oil ( $0.19 \mathrm{~g}, 41 \%$ yield).

${ }^{1} \mathrm{H} \mathrm{NMR}\left(\mathrm{CDCl}_{3}, 600 \mathrm{MHz}\right): \delta 6.15(\mathrm{dt}, J=11.3,2.3,2.3 \mathrm{~Hz}, 1 \mathrm{H}), 6.05(\mathrm{~d}, J=11.4 \mathrm{~Hz}, 1 \mathrm{H})$, $3.75(\mathrm{~s}, 3 \mathrm{H}), 3.55(\mathrm{t}, J=6.7,2 \mathrm{H}), 2.47(\mathrm{td}, J=7.0,7.0,2.1 \mathrm{~Hz}, 2 \mathrm{H}), 1.80(\mathrm{t}, J=6.8 \mathrm{~Hz}, 2 \mathrm{H})$, $1.61(\mathrm{~m}, 2 \mathrm{H}), 1.47(\mathrm{~m}, 4 \mathrm{H})$.

${ }^{13} \mathrm{C} \mathrm{NMR}\left(\mathrm{CDCl}_{3}, 125 \mathrm{MHz}\right): \delta 165.4,127.2,124.4,104.2,77.9,51.5,45.2,32.6,28.3,28.2$, 26.5, 20.1.

HRMS (CI+): Calculated for $\mathrm{C}_{12} \mathrm{H}_{18} \mathrm{ClO}_{2}\left([\mathrm{M}+\mathrm{H}]^{+}\right), 229.0995$; found 229.0990 .
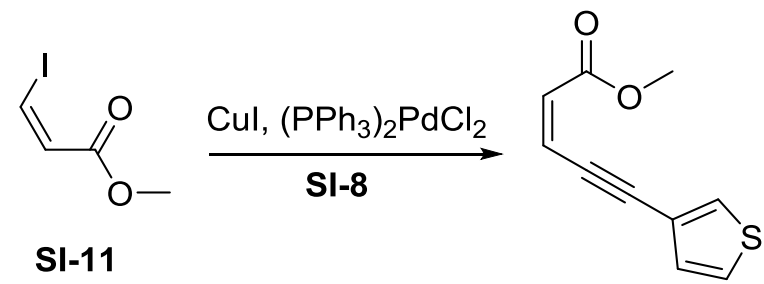

SI-11

$1 \mathrm{~m}$

Methyl (Z)-5-(thiophen-3-yl)pent-2-en-4-ynoate (1m). A flask was charged with compound SI-11 ( $0.500 \mathrm{~g}, 2.35 \mathrm{mmol}, 1.00$ equiv), $\left(\mathrm{PPh}_{3}\right)_{2} \mathrm{PdCl}_{2}$ (0.124 $\mathrm{mg}, 0.176 \mathrm{mmol}, 0.0750$ equiv), $\mathrm{CuI}(0.017 \mathrm{~g}, 0.087 \mathrm{mmol}, 0.037$ equiv), and a stir bar. The flask was then evacuated and refilled with $\mathrm{N}_{2}$ three times before $5.3 \mathrm{~mL}$ of $\mathrm{Et}_{3} \mathrm{~N}$ was added. Compound $\mathbf{S I - 8}(0.28 \mathrm{~mL}, 2.8 \mathrm{mmol}, 1.2$ equiv) was then syringed into the reaction mixture, which was then heated to $50{ }^{\circ} \mathrm{C}$ and stirred for $18 \mathrm{~h}$. At this time, analysis by TLC (10\% EtOAc/hexanes) indicated full consumption of starting material. The reaction mixture was diluted with $150 \mathrm{~mL} \mathrm{Et}_{2} \mathrm{O}$ and washed with $\mathrm{NH}_{4} \mathrm{Cl}(1$ $\times 25 \mathrm{~mL})$, water $(1 \times 25 \mathrm{~mL})$, brine $(1 \times 25 \mathrm{~mL})$, dried over $\mathrm{Na}_{2} \mathrm{SO}_{4}$, filtered, and concentrated in vacuo. The resulting oily residue was purified by column chromatography using an elution gradient from $100 \%$ hexanes to $10 \%$ EtOAc/hexanes. Product-containing fractions were combined and concentrated in vacuo, and volatiles were removed at c.a. 10 mTorr for $18 \mathrm{~h}$ to afford $1 \mathbf{m}$ as a viscous light yellow oil ( $0.22 \mathrm{~g}, 48 \%$ yield). 
${ }^{1} \mathrm{H}$ NMR $\left(\mathrm{CDCl}_{3}, 600 \mathrm{MHz}\right): \delta 7.59(\mathrm{~d}, J=2.9 \mathrm{~Hz}, 1 \mathrm{H}), 7.28(\mathrm{dd}, J=4.9,3.1 \mathrm{~Hz}, 1 \mathrm{H}), 7.18(\mathrm{~d}, J$ $=5.0 \mathrm{~Hz}, 1 \mathrm{H}), 6.34(\mathrm{~d}, J=11.5 \mathrm{~Hz}, 1 \mathrm{H}), 6.12(\mathrm{~d}, J=11.5 \mathrm{~Hz}, 1 \mathrm{H}), 3.78(\mathrm{~s}, 3 \mathrm{H})$.

${ }^{13} \mathrm{C} \mathrm{NMR}\left(\mathrm{CDCl}_{3}, 125 \mathrm{MHz}\right): \delta 165.3,130.7,130.0,127.5,125.7,123.3,121.8,96.8,86.3,51.6$. HRMS (CI+): Calculated for $\mathrm{C}_{10} \mathrm{H}_{8} \mathrm{SO}_{2}\left([\mathrm{M}]^{+}\right), 192.0245$; found 192.0240.

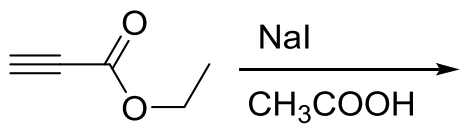

SI-13

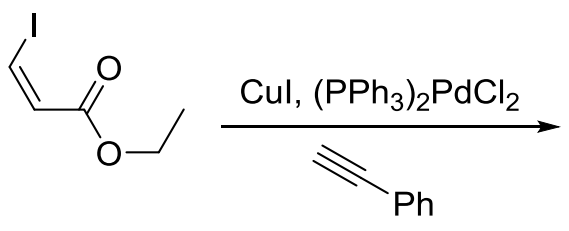

SI-14

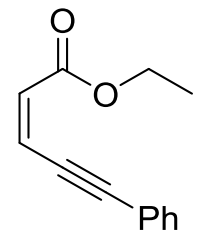

1n

Ethyl (Z)-3-iodoacrylate (SI-14) was prepared according to a literature procedure ${ }^{10}$ in $67 \%$ yield. ${ }^{1} \mathrm{H} \mathrm{NMR}\left(\mathrm{CDCl}_{3}, 600 \mathrm{MHz}\right): \delta 7.43(\mathrm{~d}, J=8.9 \mathrm{~Hz}, 1 \mathrm{H}), 6.89(\mathrm{~d}, J=8.9 \mathrm{~Hz}, 1 \mathrm{H}), 4.25$ (q, $J=7.1 \mathrm{~Hz}, 2 \mathrm{H}), 1.32(\mathrm{t}, J=7.1 \mathrm{~Hz}, 3 \mathrm{H})$. This spectrum is in agreement with previously reported spectral data.

Ethyl (Z)-5-phenylpent-2-en-4-ynoate (1n). A flask was charged with compound SI-14 (0.50 g, $2.2 \mathrm{mmol}, 1.0$ equiv), $\left(\mathrm{PPh}_{3}\right)_{2} \mathrm{PdCl}_{2}(0.12 \mathrm{~g}, 0.17 \mathrm{mmol}, 0.080$ equiv), and $\mathrm{CuI}(0.015 \mathrm{~g}, 0.081$ mmol, 0.040 equiv). The flask was then evacuated and refilled with $\mathrm{N}_{2}$ three times before $5 \mathrm{~mL}$ of $\mathrm{Et}_{3} \mathrm{~N}$ was added. Phenylacetylene $(0.29 \mathrm{~mL}, 2.6 \mathrm{mmol}, 1.2$ equiv) was then syringed into the reaction mixture, which was then heated to $50{ }^{\circ} \mathrm{C}$ and stirred for $18 \mathrm{~h}$ under dynamic $\mathrm{N}_{2}$. At this time, analysis by TLC (10\% EtOAc/hexanes) indicated full consumption of starting material. The reaction mixture was diluted with $150 \mathrm{~mL} \mathrm{Et}_{2} \mathrm{O}$ and washed with $\mathrm{NH}_{4} \mathrm{Cl}(1 \times 25 \mathrm{~mL})$, water $(1 \times 25 \mathrm{~mL})$, brine $(1 \times 25 \mathrm{~mL})$, dried over $\mathrm{Na}_{2} \mathrm{SO}_{4}$, filtered, and concentrated in vacuo. The resulting oily residue was purified by column chromatography using an elution gradient from $100 \%$ hexanes to $10 \%$ EtOAc/hexanes. Product-containing fractions were combined and concentrated in vacuo, and volatiles were removed at c.a. 10 mTorr for $18 \mathrm{~h}$ to afford $\mathbf{1 n}$ as a viscous light yellow oil $\left(0.28 \mathrm{~g}, 63 \%\right.$ yield). ${ }^{1} \mathrm{H} \mathrm{NMR}\left(\mathrm{CDCl}_{3}, 600 \mathrm{MHz}\right): \delta 7.53$ (dd, $J=7.4,2.1$ $\mathrm{Hz}, 1 \mathrm{H}), 7.36-7.33(\mathrm{~m}, 3 \mathrm{H}), 4.27(\mathrm{q}, J=7.1 \mathrm{~Hz}, 2 \mathrm{H}), 1.34(\mathrm{t}, J=7.1 \mathrm{~Hz}, 3 \mathrm{H})$. This spectrum is in agreement with previously reported spectral data. ${ }^{2}$

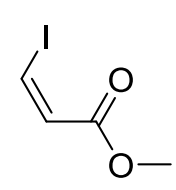

SI-11

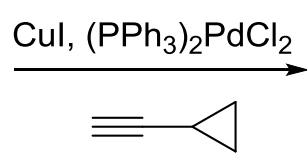

SI-15

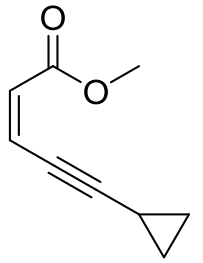

$1 p$

Methyl (Z)-5-cyclopropylpent-2-en-4-ynoate (1p). This procedure was performed in a $\mathrm{N}_{2^{-}}$ filled glove box. A $20 \mathrm{~mL}$ vial was charged with compound SI-11 (0.424 g, $2.00 \mathrm{mmol}, 1.00$ equiv), $\left(\mathrm{PPh}_{3}\right)_{2} \mathrm{PdCl}_{2}$ (0.112 g, $0.160 \mathrm{mmol}, 0.0750$ equiv), $\mathrm{CuI}(0.015 \mathrm{~g}, 0.080 \mathrm{mmol}, 0.037$ equiv), and a stir bar. $5 \mathrm{~mL}$ of $\mathrm{Et}_{3} \mathrm{~N}$ was added. Compound SI-15 (0.20 mL, $2.4 \mathrm{mmol}, 1.2$ equiv) was then syringed into the reaction mixture, which was then heated to $50{ }^{\circ} \mathrm{C}$ and stirred for $18 \mathrm{~h}$. At this time, analysis by TLC $(10 \%$ EtOAc/hexanes) indicated full consumption of starting 
material. The reaction mixture was diluted with $150 \mathrm{~mL} \mathrm{Et}_{2} \mathrm{O}$ and washed with $\mathrm{NH}_{4} \mathrm{Cl}(1 \times 25$ $\mathrm{mL})$, water $(1 \times 25 \mathrm{~mL})$, brine $(1 \times 25 \mathrm{~mL})$, dried over $\mathrm{Na}_{2} \mathrm{SO}_{4}$, filtered, and concentrated in vacuo. The resulting oily residue was purified by column chromatography using an elution gradient from $100 \%$ hexanes to $10 \%$ EtOAc/hexanes. Product-containing fractions were combined and concentrated in vacuo [NOTE: product may be volatile] to afford $115 \mathrm{mg}$ of $\mathbf{1 p}$ as a yellow liquid in $\sim 91 \%$ purity.

${ }^{1} \mathrm{H} \mathrm{NMR}\left(\mathrm{CDCl}_{3}, 600 \mathrm{MHz}\right): \delta 6.11(\mathrm{dd}, J=11.4,2.4 \mathrm{~Hz}, 1 \mathrm{H}), 6.01(\mathrm{~d}, J=11.3 \mathrm{~Hz}, 1 \mathrm{H}), 3.74$ (s, 3H), 1.49 (ddt, 7.9, 5.3, 2.8, 2.8 Hz, 1H), 0.92 (m, 2H), 0.86 (m, 2H).

${ }^{13} \mathrm{C} \mathrm{NMR}\left(\mathrm{CDCl}_{3}, 125 \mathrm{MHz}\right): \delta 165.5,126.7,124.5,108.3,73.6,51.5,9.7,1.1$.

HRMS (CI+): Calculated for $\mathrm{C}_{9} \mathrm{H}_{10} \mathrm{O}_{2}\left([\mathrm{M}]^{+}\right), 150.0681$; found 150.0677 .

\section{B. Boron Electrophile Screen}

Table S1 (Table 1 in Manuscript). Boron Reagent Variation

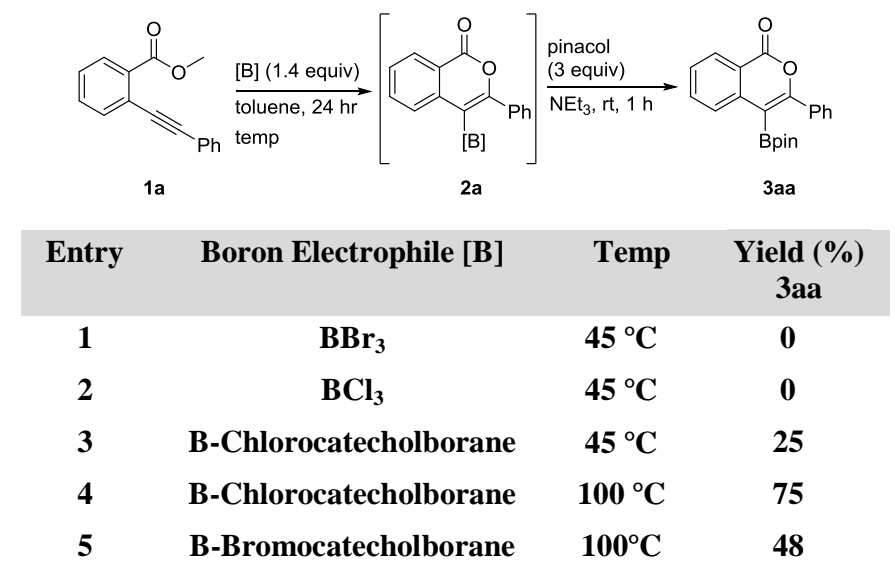

\section{General Procedure: Entries 1 and 2}

This screen was carried out in a nitrogen-filled glove box. A $4 \mathrm{~mL}$ vial was charged with 1a $(0.118 \mathrm{~g}, 0.500 \mathrm{mmol}, 1.00$ equiv) and $0.5 \mathrm{~mL}$ toluene. $0.6 \mathrm{~mL}$ (1.2 equiv) of a $1 \mathrm{M}$ solution of either $\mathrm{BBr}_{3}$ or $\mathrm{BCl}_{3}$ was then added to the vial, and the vial was sealed and heated to $45^{\circ} \mathrm{C}$ for 24 h. At this time, the reaction mixture was cooled down to room temperature. In a separate vial, pinacol (0.18 g, $1.5 \mathrm{mmol}, 3.0$ equiv) was dissolved in $\mathrm{Et}_{3} \mathrm{~N}$ (1.0 mL, $7.5 \mathrm{mmol}, 15$ equiv). This solution was then added to the reaction mixture. The resulting solution was then stirred for $1 \mathrm{~h}$ at room temperature. The solution was then concentrated in vacuo. Analysis of the resulting residue via ${ }^{1} \mathrm{H}$ NMR spectroscopy $\left(\mathrm{CDCl}_{3}, 600 \mathrm{MHz}\right)$ and ${ }^{11} \mathrm{~B} \mathrm{NMR}$ Spectroscopy $\left(\mathrm{CDCl}_{3}, 126 \mathrm{MHz}\right)$ confirmed that the desired product 3aa was not produced.

\section{General Procedure: Entries 3-5}

This screen was carried out in a nitrogen-filled glove box. A $4 \mathrm{~mL}$ vial was charged with 1a $(0.118 \mathrm{~g}, \quad 0.500 \mathrm{mmol}, 1.00$ equiv) and $0.5 \mathrm{~mL}$ toluene. In a separate vial, $B$ chlorocatecholborane $(0.70 \mathrm{mmol}, 1.4$ equiv) or $B$-bromocatecholborane $(0.70 \mathrm{mmol}, 1.4 \mathrm{equiv})$ was added. The initial reaction vial was then transferred to the boron-containing vial via pipette, 
and this vial was sealed and heated to the specified temperature for $24 \mathrm{~h}$. At this time, the reaction mixture was cooled down to room temperature. In a separate vial, pinacol $(0.18 \mathrm{~g}, 1.5$ mmol, 3.0 equiv) was dissolved in $\mathrm{Et}_{3} \mathrm{~N}$ (1.0 mL, $7.5 \mathrm{mmol}, 15$ equiv). This solution was then added to the reaction mixture. The resulting solution was then stirred for $1 \mathrm{~h}$ at room temperature. The solution was then concentrated in vacuo. The resulting oily residue was purified by column chromatography using an elution gradient from $100 \%$ hexanes to $15 \%$ EtOAc/hexanes. Product-containing fractions were combined and concentrated in vacuo, and volatiles were removed at c.a. 10 mTorr for $18 \mathrm{~h}$ to afford 3aa as a light yellow oil, which solidified upon standing. The ${ }^{1} \mathrm{H}$ NMR spectrum for each entry was then compared to the authentic sample (see section D, product 3aa) to establish identity.

\section{Reaction Condition Optimization}

Table S2. Optimization of the Oxyboration Reaction

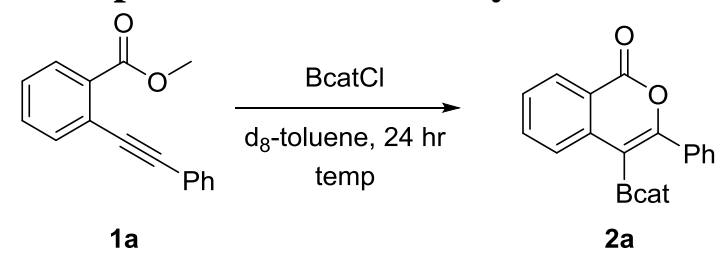

\begin{tabular}{|cccc|}
\hline Entry & Equivalents of BcatCl & Temp & $2 \mathrm{2a:1a}$ \\
\hline 1 & 1.0 equiv & $100^{\circ} \mathrm{C}$ & $76: 24$ \\
2 & 1.2 equiv & $100^{\circ} \mathrm{C}$ & $81: 19$ \\
3 & 1.3 equiv & $100^{\circ} \mathrm{C}$ & $87: 13$ \\
4 & 1.4 equiv & $100^{\circ} \mathrm{C}$ & $95: 5$ \\
5 & 1.4 equiv & $75^{\circ} \mathrm{C}$ & $86: 14$ \\
6 & 1.4 equiv & $45^{\circ} \mathrm{C}$ & $40: 60$
\end{tabular}

Reaction condition screening reactions were set up in a $\mathrm{N}_{2}$-filled glovebox. 1a (118 mg, 0.500 mmol, 1.00 equiv) was dissolved in anhydrous $\mathrm{d}_{8}$-toluene $(0.50 \mathrm{~mL})$ and added to a dram vial containing $B$-chlorocatecholborane in the below amounts (1.00-1.40 equiv). After mixing thoroughly, the reaction mixture was transferred to a J. Young NMR tube, removed from the glovebox, and heated in a preheated oil bath for $24 \mathrm{~h}$. The progress of the reaction was then monitored by ${ }^{1} \mathrm{H}$ and ${ }^{11} \mathrm{~B}$ NMR spectroscopy, with characteristic product $(\mathbf{2 a})$ peaks at $\delta=8.26$ ppm in the ${ }^{1} \mathrm{H}$ NMR spectrum, and $\delta \sim 32.1 \mathrm{ppm}$ in the ${ }^{11} \mathrm{~B}$ NMR spectrum in $d_{8}$-toluene.

Note: the optimized concentration was $1.0 \mathrm{M}$ was the best; when higher concentrations were tested, solubility issues were encountered. 


\section{Synthesis of $O$-Alkyl Esters and Screen}<smiles>C#Cc1ccccc1-c1ccccc1</smiles>

SI-16<smiles>CCOC(=O)c1ccccc1C#Cc1ccccc1</smiles>

$1 \mathbf{q}$

Ethyl 2-(phenylethynyl)benzoate (1q). A flask was charged with compound SI-16 (0.96 g, 3.5 mmol, 1.0 equiv), $\left(\mathrm{PPh}_{3}\right)_{2} \mathrm{PdCl}_{2}(0.049 \mathrm{~g}, 0.070 \mathrm{mmol}, 0.020$ equiv), and $\mathrm{CuI}(0.027 \mathrm{~g}, 0.14$ mmol, 0.040 equiv). The flask was then evacuated and refilled with $\mathrm{N}_{2}$ three times before $7 \mathrm{~mL}$ of acetonitrile and $\mathrm{Et}_{3} \mathrm{~N}(3.8 \mathrm{~mL}, 28 \mathrm{mmol}, 8.0$ equiv) were added. Phenylacetylene $(0.42 \mathrm{~mL}$, $3.8 \mathrm{mmol}, 1.1$ equiv) was then syringed into the reaction mixture which stirred for $18 \mathrm{~h}$ under dynamic $\mathrm{N}_{2}$. At this time, analysis by TLC (10\% EtOAc/hexanes) indicated full consumption of starting material. The reaction mixture was diluted with $200 \mathrm{~mL}$ EtOAc and washed with $\mathrm{NH}_{4} \mathrm{Cl}$ $(1 \times 25 \mathrm{~mL})$, water $(1 \times 25 \mathrm{~mL})$, brine $(1 \times 25 \mathrm{~mL})$, dried over $\mathrm{Na}_{2} \mathrm{SO}_{4}$, filtered, and concentrated in vacuo. The resulting oily residue was purified by column chromatography using an elution gradient from $100 \%$ hexanes to $5 \%$ EtOAc/hexanes. Product-containing fractions were combined and concentrated in vacuo, and volatiles were removed at c.a. 10 mTorr for 18 h to afford 1q as a light yellow oil $(0.68 \mathrm{~g}, 78 \%$ yield $) .{ }^{1} \mathrm{H} \mathrm{NMR}\left(\mathrm{CDCl}_{3}, 600 \mathrm{MHz}\right): \delta 7.99(\mathrm{dd}, J=$ 7.9, $0.8 \mathrm{~Hz}, 1 \mathrm{H}), 7.65(\mathrm{dd}, J=7.7,0.6 \mathrm{~Hz}, 1 \mathrm{H}), 7.60-7.58(\mathrm{~m}, 2 \mathrm{H}), 7.47$ (app t, $J=7.6 \mathrm{~Hz}, 1 \mathrm{H})$, 7.38-7.34 (m, 4H), $4.44(\mathrm{q}, J=7.2 \mathrm{~Hz}, 2 \mathrm{H}), 1.41(\mathrm{t}, J=7.2 \mathrm{~Hz}, 3 \mathrm{H})$. This spectrum is in agreement with previously reported spectral data. ${ }^{12}$<smiles>O=C(O)c1ccccc1I</smiles>

SI-17<smiles>CC(C)OC(=O)c1ccccc1I</smiles>

SI-18

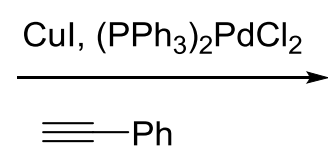

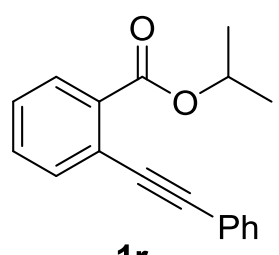

$1 \mathrm{r}$

Isopropyl 2-iodobenzoate (SI-18) was prepared according to a literature procedure ${ }^{13}$ in $56 \%$ yield. ${ }^{1} \mathrm{H} \mathrm{NMR}\left(\mathrm{CDCl}_{3}, 500 \mathrm{MHz}\right): \delta 7.90(\mathrm{dd}, J=7.9,1.0 \mathrm{~Hz}, 1 \mathrm{H}), 7.68(\mathrm{dd}, J=7.7,1.7 \mathrm{~Hz}$, $1 \mathrm{H}), 7.37(\mathrm{td}, J=7.7,1.0 \mathrm{~Hz}, 1 \mathrm{H}), 7.10(\mathrm{td}, J=7.9,1.7 \mathrm{~Hz}, 1 \mathrm{H}), 5.24$ (hept, $J=6.2 \mathrm{~Hz}, 1 \mathrm{H})$, $1.39(\mathrm{~d}, J=6.2 \mathrm{~Hz}, 6 \mathrm{H})$. This spectrum is in agreement with previously reported spectral data. ${ }^{13}$

Isopropyl 2-(phenylethynyl)benzoate (1r). A flask was charged with compound SI-18 $(0.50 \mathrm{~g}$, $1.7 \mathrm{mmol}, 1.0$ equiv), $\left(\mathrm{PPh}_{3}\right)_{2} \mathrm{PdCl}_{2}(0.024 \mathrm{~g}, 0.034 \mathrm{mmol}, 0.020$ equiv), and $\mathrm{CuI}(0.013 \mathrm{~g}, 0.070$ mmol, 0.040 equiv). The flask was then evacuated and refilled with $\mathrm{N}_{2}$ three times before $4 \mathrm{~mL}$ of acetonitrile and $\mathrm{Et}_{3} \mathrm{~N}$ (1.9 mL, $14 \mathrm{mmol}, 8.0$ equiv) were added. Phenylacetylene $(0.21 \mathrm{~mL}$, $1.9 \mathrm{mmol}, 1.1$ equiv) was then syringed into the reaction mixture which stirred for $18 \mathrm{~h}$ under dynamic $\mathrm{N}_{2}$. At this time, analysis by TLC (15\% EtOAc/hexanes) indicated full consumption of starting material. The reaction mixture was diluted with $200 \mathrm{~mL}$ EtOAc and washed with $\mathrm{NH}_{4} \mathrm{Cl}$ $(1 \times 25 \mathrm{~mL})$, water $(1 \times 25 \mathrm{~mL})$, brine $(1 \times 25 \mathrm{~mL})$, dried over $\mathrm{Na}_{2} \mathrm{SO}_{4}$, filtered, and 
concentrated in vacuo. The resulting oily residue was purified by column chromatography using an elution gradient from $100 \%$ hexanes to $5 \%$ EtOAc/hexanes. Product-containing fractions were combined and concentrated in vacuo, and volatiles were removed at c.a. 10 mTorr for $18 \mathrm{~h}$ to afford $1 \mathbf{r}$ as a light yellow oil $(0.39 \mathrm{~g}, 85 \%$ yield $) .{ }^{1} \mathrm{H} \mathrm{NMR}\left(\mathrm{CDCl}_{3}, 600 \mathrm{MHz}\right): \delta 7.95(\mathrm{dt}, J=$ 7.9, $1.0 \mathrm{~Hz}, 1 \mathrm{H}), 7.65-7.63(\mathrm{~m}, 1 \mathrm{H}), 7.58-7.56(\mathrm{~m}, 2 \mathrm{H}), 7.50(\mathrm{td}, J=7.6,1.4 \mathrm{~Hz}, 1 \mathrm{H}), 7.39-7.34$ $(\mathrm{m}, 4 \mathrm{H}), 5.30$ (hept, $J=6.2 \mathrm{~Hz}, 1 \mathrm{H}), 1.38(\mathrm{~d}, J=6.2 \mathrm{~Hz}, 6 \mathrm{H})$. This spectrum is in agreement with previously reported spectral data. ${ }^{14}$<smiles>O=C(Cl)c1ccccc1I</smiles>

SI-19<smiles>CC(C)(C)OC(=O)c1ccc(C(F)(F)F)cc1I</smiles>

SI-20

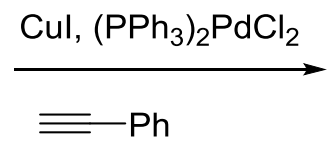

$\overline{\bar{~}} \mathrm{Ph}$

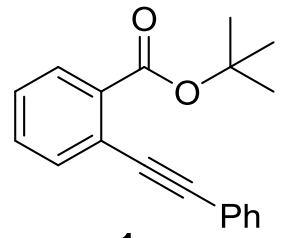

$1 \mathrm{~s}$

tert-Butyl 2-iodobenzoate (SI-20) was prepared according to a literature procedure in $75 \%$ yield. ${ }^{1} \mathrm{H} \mathrm{NMR}\left(\mathrm{CDCl}_{3}, 600 \mathrm{MHz}\right): \delta 7.94(\mathrm{dd}, J=7.9,1.0 \mathrm{~Hz}, 1 \mathrm{H}), 7.68(\mathrm{dd}, J=7.7,1.7 \mathrm{~Hz}$, $1 \mathrm{H}), 7.37(\mathrm{td}, J=7.7,1.0 \mathrm{~Hz}, 1 \mathrm{H}), 7.10(\mathrm{td}, J=7.9,1.7 \mathrm{~Hz}, 1 \mathrm{H}), 1.6(\mathrm{~s}, 29 \mathrm{H})$. This spectrum is in agreement with previously reported spectral data. ${ }^{13}$

tert-Butyl 2-(phenylethynyl)benzoate (1s). A flask was charged with compound SI-20 (0.49 g, $1.6 \mathrm{mmol}, 1.0$ equiv), $\left(\mathrm{PPh}_{3}\right)_{2} \mathrm{PdCl}_{2}(0.022 \mathrm{~g}, 0.032 \mathrm{mmol}, 0.020$ equiv), and $\mathrm{CuI}(0.012 \mathrm{~g}, 0.064$ mmol, 0.040 equiv). The flask was then evacuated and refilled with $\mathrm{N}_{2}$ three times before $3 \mathrm{~mL}$ of acetonitrile and $\mathrm{Et}_{3} \mathrm{~N}(1.8 \mathrm{~mL}, 13 \mathrm{mmol}, 8.0$ equiv) were added. Phenylacetylene $(0.20 \mathrm{~mL}$, $1.8 \mathrm{mmol}, 1.1$ equiv) was then syringed into the reaction mixture which stirred for $18 \mathrm{~h}$ under dynamic $\mathrm{N}_{2}$. At this time, analysis by TLC (10\% EtOAc/hexanes) indicated full consumption of starting material. The reaction mixture was diluted with $200 \mathrm{~mL} \mathrm{EtOAc}$ and washed with $\mathrm{NH}_{4} \mathrm{Cl}$ $(1 \times 25 \mathrm{~mL})$, water $(1 \times 25 \mathrm{~mL})$, brine $(1 \times 25 \mathrm{~mL})$, dried over $\mathrm{Na}_{2} \mathrm{SO}_{4}$, filtered, and concentrated in vacuo. The resulting oily residue was purified by column chromatography using an elution gradient from $100 \%$ hexanes to $5 \%$ EtOAc/hexanes. Product-containing fractions were combined and concentrated in vacuo, and volatiles were removed at c.a. 10 mTorr for $18 \mathrm{~h}$ to afford $1 \mathrm{~s}$ as a light yellow oil $(0.40 \mathrm{~g}, 90 \%$ yield $) .{ }^{1} \mathrm{H}$ NMR $\left(\mathrm{CDCl}_{3}, 600 \mathrm{MHz}\right): \delta 7.86(\mathrm{dd}, J=$ $7.9,0.8 \mathrm{~Hz}, 1 \mathrm{H}), 7.56(\mathrm{dd}, J=7.7,0.8 \mathrm{~Hz}, 1 \mathrm{H}), 7.51$ (dd, $J=8.1,1.9 \mathrm{~Hz}, 2 \mathrm{H}), 7.39$ (td, $J=7.7$, $1.3 \mathrm{~Hz}, 1 \mathrm{H}), 7.32-7.28(\mathrm{~m}, 4 \mathrm{H}), 1.56(\mathrm{~s}, 9 \mathrm{H})$. This spectrum is in agreement with previously reported spectral data. ${ }^{2}$ 
Table S3 (Table 3 in Manuscript). Mechanistic Insight from $O$-Alkyl Group Variance of the Oxyboration Reaction

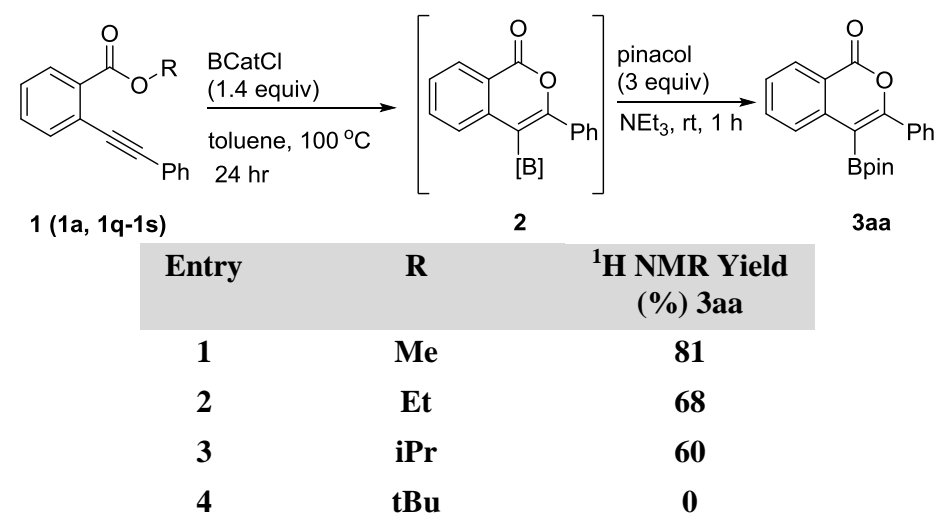

\section{General Procedure}

This screen was carried out in a nitrogen-filled glove box. A $4 \mathrm{~mL}$ vial was charged with the desired $O$-alkyl ester (1a, 1q-1s) $(0.50 \mathrm{mmol}, 1.0$ equiv) and $0.5 \mathrm{~mL}$ toluene. In a separate vial, $B$-chlorocatecholborane $(0.70 \mathrm{mmol}, 1.4$ equiv $)$ was added. The solution in the initial reaction vial was then transferred to the boron-containing vial via pipette, and this vial was sealed and heated to $100{ }^{\circ} \mathrm{C}$ for $24 \mathrm{~h}$. At this time, the reaction mixture was cooled to room temperature. In a separate vial, pinacol (0.18 g, $1.5 \mathrm{mmol}, 3.0$ equiv) was dissolved in $\mathrm{Et}_{3} \mathrm{~N}$ (1.0 mL, $7.5 \mathrm{mmol}, 15$ equiv). This solution was then added to the reaction mixture via pipette. The resulting solution was then stirred for $1 \mathrm{~h}$ at room temperature and then concentrated in vacuo. An ${ }^{1} \mathrm{H}$ NMR spectrum was then taken of each crude mixture in $\mathrm{CDCl}_{3}$; mesitylene $(50 . \mu \mathrm{L}, 0.36 \mathrm{mmol}, 0.72$ equiv) was added to the sample via gas tight syringe to determine the yield of the desired borylated isocoumarin 3aa. In entry $4(\mathrm{R}=t \mathrm{Bu})$, the mesitylene was compared to characteristic peaks of the benzoic acid derivative of 1a from an authentic sample synthesized using a known procedure. $^{15}$

\section{Procedure to Monitor the Formation of Isobutylene from Entry 4}

A $4 \mathrm{~mL}$ vial was charged with compound $1 \mathrm{~s}(0.10 \mathrm{~g}, 0.37 \mathrm{mmol}, 1.0$ equiv $), 1,3,5-$ triisopropylbenzene ( $30 \mu \mathrm{L}, 0.12 \mathrm{mmol}, 0.24$ equiv), and $0.4 \mathrm{~mL} d_{8}$-toluene. In a separate vial, $B$-chlorocatecholborane $(0.080 \mathrm{~g}, 0.52 \mathrm{mmol}, 1.4$ equiv) was added. The solution in the initial reaction vial was then transferred to the boron-containing vial via pipette, and then this mixture was transferred to a J-young tube via pipette. The tube was heated to $100{ }^{\circ} \mathrm{C}$. ${ }^{1} \mathrm{H} \mathrm{NMR}$ spectra were taken at $t=3 \mathrm{~h}$ and $24 \mathrm{~h}$ to monitor isobutylene formation, as well as to confirm that catecholboronic ester $2 \mathrm{~s}$ did not form.

\section{E. Synthesis and Isolation of Carboxyboration Products 3aa-3p}

\section{General Remarks}

For synthetic ease, these reactions were carried out in a nitrogen-filled glovebox unless specified otherwise. $B$-Chlorocatecholborane is water-reactive and should be stored cool $\left(0{ }^{\circ} \mathrm{C}\right.$ or lower $)$ in a desiccator or glovebox when not in use. The ipso $\mathrm{C}-\mathrm{B}$ bond is not detected by ${ }^{13} \mathrm{C}$ NMR spectroscopy. 


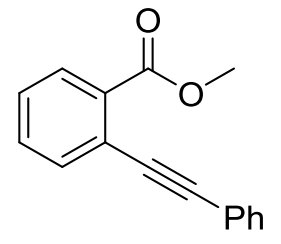

$1 \mathrm{a}$

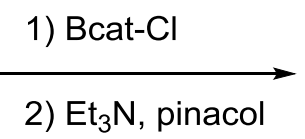

2) $\mathrm{Et}_{3} \mathrm{~N}$, pinacol<smiles>O=c1oc(-c2ccccc2)c(-c2ccccc2)c2ccccc12</smiles>

3aa

3-phenyl-4-(4,4,5,5-tetramethyl-1,3,2-dioxaborolan-2-yl)-1H-isochromen-1-one (3aa). A vial was charged with $1 \mathrm{a}(0.118 \mathrm{~g}, 0.500 \mathrm{mmol}, 1.00$ equiv) and $0.5 \mathrm{~mL}$ toluene. A separate vial equipped with a stir bar was charged with $B$-chlorocatecholborane $(0.108 \mathrm{~g}, 0.700 \mathrm{mmol}, 1.40$ equiv). The resulting homogenous solution from the first vial was then added dropwise over c.a. 2 min to the boron-containing vial, which stirred for $24 \mathrm{~h}$ at $100{ }^{\circ} \mathrm{C}$. At this time, the reaction mixture was cooled to room temperature and then diluted with $0.5 \mathrm{~mL}$ toluene. A separate vial was then charged with pinacol $\left(0.177 \mathrm{~g}, 1.50 \mathrm{mmol}, 3.00\right.$ equiv) and $\mathrm{Et}_{3} \mathrm{~N}$ (1.0 mL, $7.5 \mathrm{mmol}, 15$ equiv). The reaction mixture was added dropwise over c.a. 2 min to this vial, and the resulting mixture stirred for $1 \mathrm{~h}$ at room temperature. The solution was concentrated in vacuo and the resulting residue was purified by column chromatography using an elution gradient from 100\% hexanes to $15 \%$ EtOAc/hexanes. Product-containing fractions were combined and concentrated in vacuo, and volatiles were removed at c.a. $10 \mathrm{mTorr}$ for $18 \mathrm{~h}$ to afford 3aa as a yellow oil $(0.13$ $\mathrm{g}, 75 \%$ yield).

${ }^{1} \mathrm{H}$ NMR (toluene- $\left.d_{8}, 600 \mathrm{MHz}\right): \delta 8.32($ app dd, $J=7.9,1.0 \mathrm{~Hz}, 1 \mathrm{H}), 7.92($ app dd, $J=7.9,0.4$ $\mathrm{Hz}, 1 \mathrm{H}), 7.52-7.50$ (m, 2H), 7.27 (ddd, $J=15.3,6.5,1.5 \mathrm{~Hz}, 1 \mathrm{H}), 7.12-6.99$ (m, 4H), 0.99 (s, $12 \mathrm{H})$.

${ }^{13} \mathrm{C}$ NMR (toluene- $\left.d_{8}, 125 \mathrm{MHz}\right): \delta 161.4,160.9,129.1,128.7,128.1,128.1,127.8,125.3,124.9$, 84.0, 24.7, 20.7, 20.6, 20.3, 20.1.

${ }^{11} \mathrm{~B}$ NMR (toluene- $\left.d_{8}, 193 \mathrm{MHz}\right): \delta 31.5$.

HRMS (ESI+): Calculated for $\mathrm{C}_{21} \mathrm{H}_{21} \mathrm{BO}_{4} \mathrm{Na}\left([\mathrm{M}+\mathrm{Na}]^{+}\right), 371.1435$; found 371.1434.<smiles>COC(=O)c1ccccc1C#Cc1ccccc1</smiles>

$1 \mathrm{a}$

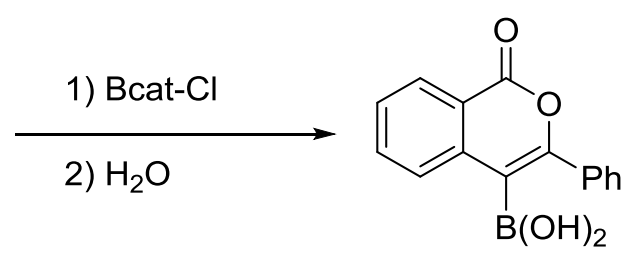

$3 a b$

(1-oxo-3-phenyl-1H-isochromen-4-yl)Boronic acid (3ab). A vial was charged with 1 a $(0.118$ $\mathrm{g}, 0.500 \mathrm{mmol}, 1.00$ equiv) and $0.5 \mathrm{~mL}$ toluene. A separate vial equipped with a stir bar was charged with $B$-chlorocatecholborane $(0.108 \mathrm{~g}, 0.700 \mathrm{mmol}, 1.40$ equiv). The resulting homogenous solution from the first vial was then added dropwise over c.a. 2 min to the boroncontaining vial, which stirred for $24 \mathrm{~h}$ at $100{ }^{\circ} \mathrm{C}$. At this time, the reaction mixture was cooled to room temperature and transferred to a vial containing $1 \mathrm{~mL}$ of water, and the resulting mixture was stirred vigorously for $18 \mathrm{~h}$ at room temperature. The solution was then filtered through a medium porosity fritted funnel. The solid was then rinsed with cold $\left(\sim 0{ }^{\circ} \mathrm{C}\right)$ water $(3 \times 3 \mathrm{~mL})$. 
The solid was dried in vacuo c.a. 10 mTorr for $18 \mathrm{~h}$ to afford $\mathbf{3 a b}$ as a light purple solid $(0.088 \mathrm{~g}$, $66 \%$ yield).

${ }^{1} \mathrm{H}$ NMR $\left(\mathrm{CD}_{3} \mathrm{CN}, 600 \mathrm{MHz}\right): \delta 8.27(\mathrm{dd}, J=7.9,0.9 \mathrm{~Hz}, 1 \mathrm{H}), 7.81(\mathrm{ddd}, J=15.2,7.2,1.4 \mathrm{~Hz}$, $1 \mathrm{H}), 7.76-7.75(\mathrm{~m}, 2 \mathrm{H}), 7.65(\operatorname{app~d}, J=7.7 \mathrm{~Hz}, 1 \mathrm{H}),(\mathrm{ddd}, J=15.2,7.9,0.5 \mathrm{~Hz}, 1 \mathrm{H}), 7.53-7.49$ $(\mathrm{m}, 3 \mathrm{H}), 6.51(\mathrm{~s}, 2 \mathrm{H})$.

${ }^{13} \mathrm{C}$ NMR $\left(\mathrm{CD}_{3} \mathrm{CN}, 125 \mathrm{MHz}\right): \delta 162.2,155.2,139.4,135.0,134.9,129.9,129.1,128.7,128.2$, 127.5, 127.0, 121.0.

${ }^{11} \mathrm{~B}$ NMR $\left(\mathrm{CD}_{3} \mathrm{CN}, 193 \mathrm{MHz}\right): \delta 30.0$.

HRMS (ESI-): Calculated for $\mathrm{C}_{15} \mathrm{H}_{11} \mathrm{BO}_{4} \mathrm{Cl}([\mathrm{M}+\mathrm{Cl}]$ ) $)$, 301.0442; found 301.0441 .<smiles>COC(=O)c1ccccc1C#Cc1ccccc1</smiles>

$1 \mathrm{a}$
1) Bcat-Cl

2) $\mathrm{KHF}_{2}, \mathrm{H}_{2} \mathrm{O}$<smiles>O=c1oc(-c2ccccc2)c(Br)c2ccccc12</smiles>

3ac

3-Phenyl-4-(trifluoro- $\lambda^{4}$-boranyl)-1H-isochromen-1-one, potassium salt (3ac). A vial was charged with $1 \mathrm{a}(0.118 \mathrm{~g}, 0.500 \mathrm{mmol}, 1.00$ equiv) and $0.5 \mathrm{~mL}$ toluene. A separate vial equipped with a stir bar was charged with $B$-chlorocatecholborane $(0.108 \mathrm{~g}, 0.700 \mathrm{mmol}, 1.40$ equiv). The resulting homogenous solution from the first vial was then added dropwise over c.a. 2 min to the boron-containing vial, which stirred for $24 \mathrm{~h}$ at $100{ }^{\circ} \mathrm{C}$. At this time, the reaction mixture was cooled to room temperature and then concentrated in vacuo. The residue was then dissolved in 1 $\mathrm{mL}$ of acetone and then transferred via pipette to another flask containing a solution of $\mathrm{KHF}_{2}$ $\left(0.137 \mathrm{~g}, 1.80 \mathrm{mmol}, 3.50\right.$ equiv) in $1.5 \mathrm{~mL}$ of $\mathrm{H}_{2} \mathrm{O}$. The resulting mixture was stirred for $1 \mathrm{~h}$ then concentrated in vacuo at c.a. 10 mTorr for $1 \mathrm{~h}$. The product was then filtered through a medium porosity fritted funnel. The solid was then rinsed with cold $\left(\sim 0{ }^{\circ} \mathrm{C}\right)$ water $(3 \times 3 \mathrm{~mL})$ and ether $(3$ x $3 \mathrm{~mL}$ ). The solid was dried in vacuo c.a. 10 mTorr for $18 \mathrm{~h}$ to afford 3ac as a white solid (0.103 g, 63\% yield).

${ }^{1} \mathrm{H}$ NMR $\left(\left(\mathrm{CD}_{3}\right)_{2} \mathrm{CO}, 600 \mathrm{MHz}\right): \delta 8.37(\mathrm{~d}, J=8.1 \mathrm{~Hz}, 1 \mathrm{H}), 8.16(\mathrm{~d}, J=7.7 \mathrm{~Hz}, 1 \mathrm{H}), 7.68(\mathrm{~d}, J=$ $6.4 \mathrm{~Hz}, 2 \mathrm{H}), 7.64(\mathrm{t}, J=7.7 \mathrm{~Hz}, 1 \mathrm{H}), 7.40(\mathrm{t}, J=7.4 \mathrm{~Hz}, 1 \mathrm{H}), 7.31-7.30(\mathrm{~m}, 3 \mathrm{H})$.

${ }^{13} \mathrm{C}$ NMR $\left(\left(\mathrm{CD}_{3}\right)_{2} \mathrm{CO}, 600 \mathrm{MHz}\right): \delta 168.5,160.0,148.8,143.2,138.2,138.1,135.4,135.3,135.2$, $132.9,131.9,131.2,126.3$.

${ }^{11} \mathrm{~B}$ NMR $\left(\left(\mathrm{CD}_{3}\right)_{2} \mathrm{CO}, 193 \mathrm{MHz}\right): \delta 2.9$.

${ }^{19} \mathrm{~F}$ NMR $\left(\left(\mathrm{CD}_{3}\right)_{2} \mathrm{CO}, 376 \mathrm{MHz}\right): \delta$-131.6.

HRMS (ESI-): Calculated for $\mathrm{C}_{15} \mathrm{H}_{9} \mathrm{BF}_{3} \mathrm{O}_{2}$ ([M-K] $]^{-}$), 289.0651; found 289.0640.<smiles>CCCCC#Cc1ccccc1C(=O)OC</smiles>

$1 b$
1) Bcat-Cl

2) $\mathrm{Et}_{3} \mathrm{~N}$, pinacol<smiles>CCCCc1oc(=O)c2ccccc2c1Cc1ccccc1</smiles> 
3-butyl-4-(4,4,5,5-tetramethyl-1,3,2-dioxaborolan-2-yl)-1H-isochromen-1-one (3b). A vial was charged with $\mathbf{1 b}(0.108 \mathrm{~g}, 0.500 \mathrm{mmol}, 1.00$ equiv $)$ and $0.5 \mathrm{~mL}$ toluene. A separate vial equipped with a stir bar was charged with $B$-chlorocatecholborane $(0.108 \mathrm{~g}, 0.700 \mathrm{mmol}, 1.40$ equiv). The resulting homogenous solution from the first vial was then added dropwise over c.a. 2 min to the boron-containing vial, which stirred for $24 \mathrm{~h}$ at $100{ }^{\circ} \mathrm{C}$. At this time, the reaction mixture was cooled to room temperature and then diluted with $0.5 \mathrm{~mL}$ toluene. A separate vial was then charged with pinacol $\left(0.177 \mathrm{~g}, 1.50 \mathrm{mmol}, 3.00\right.$ equiv) and $\mathrm{Et}_{3} \mathrm{~N}$ (1.0 mL, $7.5 \mathrm{mmol}, 15$ equiv). The reaction mixture was added dropwise over c.a. 2 min to this vial, and the resulting mixture stirred for $1 \mathrm{~h}$ at room temperature. The solution was concentrated in vacuo and the resulting residue was purified by column chromatography using an elution gradient from 100\% hexanes to $15 \%$ EtOAc/hexanes. Product-containing fractions were combined and concentrated in vacuo, and volatiles were removed at c.a. $10 \mathrm{mTorr}$ for $18 \mathrm{~h}$ to afford $\mathbf{3 b}$ as a yellow oil (0.16 g, $97 \%$ yield).

${ }^{1} \mathrm{H}$ NMR $\left(\mathrm{CDCl}_{3}, 600 \mathrm{MHz}\right): \delta 8.24(\mathrm{~d}, J=9.5 \mathrm{~Hz}, 1 \mathrm{H}), 8.04(\mathrm{~d}, J=9.9 \mathrm{~Hz}, 1 \mathrm{H}), 7.65(\mathrm{td}, J=$ $9.5,1.5 \mathrm{~Hz}, 1 \mathrm{H}), 7.42-7.38(\mathrm{~m}, 1 \mathrm{H}), 2.80(\mathrm{t}, J=9.3 \mathrm{~Hz}, 2 \mathrm{H}), 1.72-1.66(\mathrm{~m}, 2 \mathrm{H}), 1.39-1.38(\mathrm{~m}$, $14 \mathrm{H}), 0.92(\mathrm{t}, J=8.9 \mathrm{~Hz}, 3 \mathrm{H})$.

${ }^{13} \mathrm{C} \mathrm{NMR}\left(\mathrm{CDCl}_{3}, 125 \mathrm{MHz}\right): \delta 166.6,162.9,139.8,134.7,129.2,127.2,126.6,119.9,84.0$, $33.7,30.9,24.9,22.5,13.9$.

${ }^{11} \mathrm{~B}$ NMR $\left(\mathrm{CDCl}_{3}, 193 \mathrm{MHz}\right): \delta 31.6$.

HRMS (ESI+): Calculated for $\mathrm{C}_{19} \mathrm{H}_{25} \mathrm{BO}_{4} \mathrm{~K}\left([\mathrm{M}+\mathrm{K}]^{+}\right)$, 367.1487; found 367.1481.

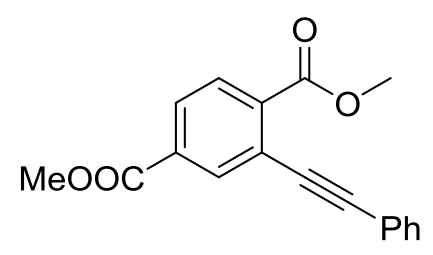

1c
1) Bcat-Cl

2) $\mathrm{Et}_{3} \mathrm{~N}$, pinacol<smiles>COC(=O)c1ccc2c(=O)oc(-c3ccccc3)c([SeH])c2c1</smiles>

$3 c$

Methyl 1-oxo-3-phenyl-4-(4,4,5,5-tetramethyl-1,3,2-dioxaborolan-2-yl)-1H-isochromene-6carboxylate (3c). A vial was charged with 1c $(0.147 \mathrm{~g}, 0.500 \mathrm{mmol}, 1.00$ equiv) and $0.5 \mathrm{~mL}$ toluene. A separate vial equipped with a stir bar was charged with $B$-chlorocatecholborane $(0.108 \mathrm{~g}, 0.700 \mathrm{mmol}, 1.40$ equiv). The resulting homogenous solution from the first vial was then added dropwise over c.a. 2 min to the boron-containing vial, which stirred for $24 \mathrm{~h}$ at 100 ${ }^{\circ} \mathrm{C}$. At this time, the reaction mixture was cooled to room temperature and then diluted with 0.5 $\mathrm{mL}$ toluene. A separate vial was then charged with pinacol $(0.177 \mathrm{~g}, 1.50 \mathrm{mmol}, 3.00 \mathrm{equiv})$ and $\mathrm{Et}_{3} \mathrm{~N}$ (1.0 mL, $7.5 \mathrm{mmol}, 15$ equiv). The reaction mixture was added dropwise over c.a. 2 min to this vial, and the resulting mixture stirred for $1 \mathrm{~h}$ at room temperature. The solution was concentrated in vacuo and the resulting residue was purified by column chromatography using an elution gradient from $100 \%$ hexanes to $20 \%$ EtOAc/hexanes. Product-containing fractions were combined and concentrated in vacuo, and volatiles were removed at c.a. 10 mTorr for $18 \mathrm{~h}$ to afford 3c as a yellow solid ( $0.13 \mathrm{~g}, 65 \%$ yield).

${ }^{1} \mathrm{H}$ NMR $\left(\mathrm{CDCl}_{3}, 600 \mathrm{MHz}\right): \delta 8.60(\mathrm{~d}, J=1.1 \mathrm{~Hz}, 1 \mathrm{H}), 8.40(\mathrm{~d}, J=8.2 \mathrm{~Hz}, 1 \mathrm{H}), 8.10(\mathrm{dd}, J=$ 8.2, $1.5 \mathrm{~Hz}, 1 \mathrm{H}), 7.71-7.70(\mathrm{~m}, 2 \mathrm{H}), 7.49-7.43(\mathrm{~m}, 3 \mathrm{H}), 3.99$ (s, 3H), 1.35 (s, 12H). 
${ }^{13} \mathrm{C} \mathrm{NMR}\left(\mathrm{CDCl}_{3}, 125 \mathrm{MHz}\right): \delta 166.0,161.8,160.3,139.7,135.4,134.2,130.4,129.9,128.8$, $128.4,128.3,128.1,123.1,84.8,52.7,24.8$.

${ }^{11} \mathrm{~B}$ NMR $\left(\mathrm{CDCl}_{3}, 193 \mathrm{MHz}\right): \delta 31.7$.

HRMS (ESI+): Calculated for $\mathrm{C}_{23} \mathrm{H}_{23} \mathrm{BO}_{6} \mathrm{Na}\left([\mathrm{M}+\mathrm{Na}]^{+}\right), 429.1490$; found 429.1499 .

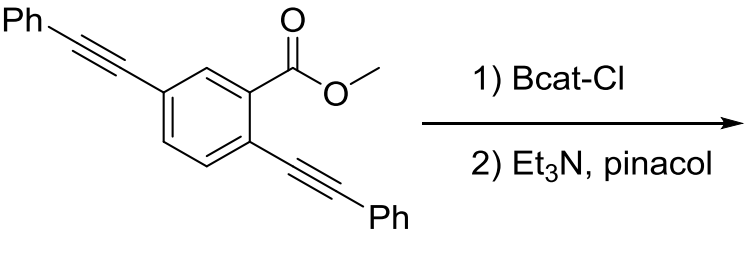

$1 d$<smiles>O=c1oc(-c2ccccc2)c(-c2ccccc2)c2ccc(C#Cc3ccccc3)cc12</smiles>

3d

3-phenyl-7-(phenylethynyl)-4-(4,4,5,5-tetramethyl-1,3,2-dioxaborolan-2-yl)-1H-

isochromen-1-one (3d). A vial was charged with $1 \mathbf{d}(0.168 \mathrm{~g}, 0.500 \mathrm{mmol}, 1.00$ equiv) and 0.5 $\mathrm{mL}$ toluene. A separate vial equipped with a stir bar was charged with $B$-chlorocatecholborane ( $0.108 \mathrm{~g}, 0.700 \mathrm{mmol}, 1.40$ equiv). The resulting homogenous solution from the first vial was then added dropwise over c.a. 2 min to the boron-containing vial, which stirred for $24 \mathrm{~h}$ at 100 ${ }^{\circ} \mathrm{C}$. At this time, the reaction mixture was cooled to room temperature and then diluted with 0.5 $\mathrm{mL}$ toluene. A separate vial was then charged with pinacol $(0.177 \mathrm{~g}, 1.50 \mathrm{mmol}, 3.00$ equiv) and $\mathrm{Et}_{3} \mathrm{~N}$ (1.0 mL, $7.5 \mathrm{mmol}, 15$ equiv). The reaction mixture was added dropwise over c.a. 2 min to this vial, and the resulting mixture stirred for $1 \mathrm{~h}$ at room temperature. The solution was concentrated in vacuo and the resulting residue was purified by column chromatography using an elution gradient from $100 \%$ hexanes to $15 \%$ EtOAc/hexanes. Product-containing fractions were combined and concentrated in vacuo, and volatiles were removed at c.a. $10 \mathrm{mTorr}$ for $18 \mathrm{~h}$ to afford $\mathbf{3 d}$ as a yellow solid $(0.15 \mathrm{~g}, 66 \%$ yield $)$.

${ }^{1} \mathrm{H} \mathrm{NMR}\left(\mathrm{CDCl}_{3}, 600 \mathrm{MHz}\right): \delta 8.50(\mathrm{~s}, 1 \mathrm{H}), 7.85-7.81(\mathrm{~m}, 2 \mathrm{H}), 7.68(\operatorname{app} \mathrm{d}, J=7.5 \mathrm{~Hz}, 2 \mathrm{H})$, 7.56-7.54 (m, 2H), 7.47-7.45 (m, 1H), 7.43-7.41 (m, 2H), 7.38-7.35 (m, 3H), $1.29(\mathrm{~s}, 12 \mathrm{H})$.

${ }^{13} \mathrm{C} \mathrm{NMR}\left(\mathrm{CDCl}_{3}, 125 \mathrm{MHz}\right): \delta 161.7,160.5,139.2,137.3,134.5,132.7,131.8 .9,130.3,128.9$, $128.8,128.5,128.2,126.6,123.1,122.8,120.3,91.5,88.3,84.6,24.9$.

${ }^{11} \mathrm{~B}$ NMR $\left(\mathrm{CDCl}_{3}, 193 \mathrm{MHz}\right): \delta 31.3$.

HRMS (ESI+): Calculated for $\mathrm{C}_{29} \mathrm{H}_{25} \mathrm{BO}_{4} \mathrm{Na}\left([\mathrm{M}+\mathrm{Na}]^{+}\right), 471.1749$; found 471.1759.

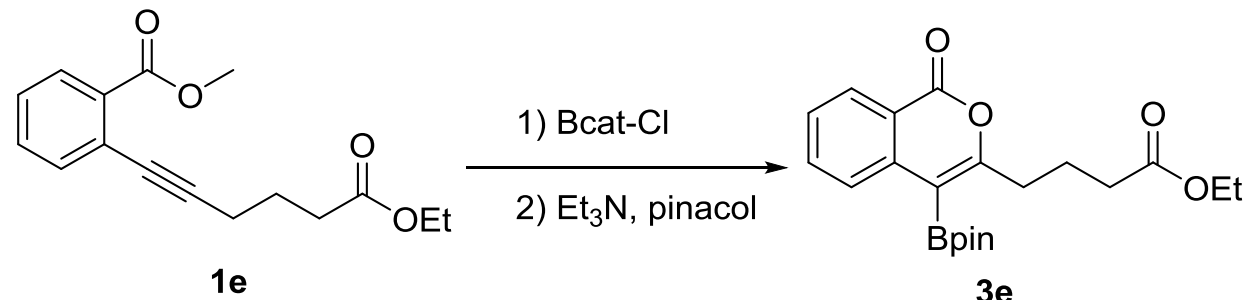

Ethyl 4-(1-oxo-4-(4,4,5,5-tetramethyl-1,3,2-dioxaborolan-2-yl)-1H-isochromen-3yl)butanoate (3e). A vial was charged with $1 \mathrm{e}(0.064 \mathrm{~g}, 0.23 \mathrm{mmol}, 1.0$ equiv) and $0.23 \mathrm{~mL}$ toluene. A separate vial equipped with a stir bar was charged with $B$-chlorocatecholborane 
( $0.050 \mathrm{~g}, 0.33 \mathrm{mmol}, 1.4$ equiv). The resulting homogenous solution from the first vial was then added dropwise over c.a. 2 min to the boron-containing vial, which stirred for $24 \mathrm{~h}$ at $100{ }^{\circ} \mathrm{C}$. At this time, the reaction mixture was cooled to room temperature and then diluted with $0.23 \mathrm{~mL}$ toluene. A separate vial was then charged with pinacol $\left(0.083 \mathrm{~g}, 0.70 \mathrm{mmol}, 3.0\right.$ equiv) and $\mathrm{Et}_{3} \mathrm{~N}$ $(0.50 \mathrm{~mL}, 3.8 \mathrm{mmol}, 15$ equiv). The reaction mixture was added dropwise over c.a. $2 \mathrm{~min}$ to this vial, and the resulting mixture stirred for $1 \mathrm{~h}$ at room temperature. The solution was concentrated in vacuo and the resulting residue was purified by column chromatography using an elution gradient from $100 \%$ hexanes to $20 \%$ EtOAc/hexanes. Product-containing fractions were combined and concentrated in vacuo, and volatiles were removed at c.a. $10 \mathrm{mTorr}$ for $18 \mathrm{~h}$ to afford $3 \mathbf{e}$ as a yellow solid $(0.050 \mathrm{~g}, 55 \%$ yield $)$.

${ }^{1} \mathrm{H} \mathrm{NMR}\left(\mathrm{CDCl}_{3}, 600 \mathrm{MHz}\right): \delta 8.25(\operatorname{app~d}, J=8.0 \mathrm{~Hz}, 1 \mathrm{H}), 8.08(\operatorname{app~d}, J=8.2 \mathrm{~Hz}, 1 \mathrm{H}), 7.66$ (ddd, $J=11.8,5.9,1.1 \mathrm{~Hz}, 1 \mathrm{H}), 7.42($ app t $, J=7.6 \mathrm{~Hz}, 1 \mathrm{H}), 4.09$ (q, $J=7.1 \mathrm{~Hz}, 2 \mathrm{H}), 2.87$ (t, $J$ $=7.4 \mathrm{~Hz}, 2 \mathrm{H}), 2.36(\mathrm{t}, J=7.6 \mathrm{~Hz}, 2 \mathrm{H}), 2.05(\mathrm{tt}, J=14.8,7.5 \mathrm{~Hz}, 2 \mathrm{H}), 1.38(\mathrm{~s}, 12 \mathrm{H}), 1.22(\mathrm{t}, J=$ $7.1 \mathrm{~Hz}, 3 \mathrm{H})$.

${ }^{13} \mathrm{C} \mathrm{NMR}\left(\mathrm{CDCl}_{3}, 125 \mathrm{MHz}\right): \delta 173.1,165.2,162.7,139.5,134.7,129.3,127.5,126.8,120.0$, 84.2, 60.4, 33.6, 33.1, 24.9, 23.7, 14.3.

${ }^{11} \mathrm{~B}$ NMR $\left(\mathrm{CDCl}_{3}, 193 \mathrm{MHz}\right): \delta 31.3$.

HRMS (ESI): Calculated for $\mathrm{C}_{21} \mathrm{H}_{27} \mathrm{BO}_{6} \mathrm{Na}\left([\mathrm{M}+\mathrm{Na}]^{+}\right), 409.1802$; found 409.1808 .<smiles>C#Cc1ccccc1C(=O)OC</smiles>

(E)-((3-oxoisobenzofuran-1(3H)-ylidene)methyl)boronic acid (3f). A vial was charged with 1f $(0.080 \mathrm{~g}, 0.50 \mathrm{mmol}, 1.0$ equiv) and $0.5 \mathrm{~mL}$ toluene. A separate vial equipped with a stir bar was charged with $B$-chlorocatecholborane $(0.108 \mathrm{~g}, 0.700 \mathrm{mmol}, 1.40$ equiv). The resulting homogenous solution from the first vial was then added dropwise over c.a. 2 min to the boroncontaining vial, which stirred for $20 \mathrm{~h}$ at $100{ }^{\circ} \mathrm{C}$. At this time, the reaction mixture was cooled to room temperature and then transferred to a vial containing $10 \mathrm{~mL}$ of water, and the resulting mixture stirred vigorously for $3 \mathrm{~h}$ at room temperature. The solution was then filtered through a medium porosity fritted funnel. The solid was then rinsed with cold $\left(\sim 0{ }^{\circ} \mathrm{C}\right)$ water $(3 \times 3 \mathrm{~mL})$. The solid was then dried in vacuo c.a. 10 mTorr for $18 \mathrm{~h}$ to afford $\mathbf{3 f}$ as a white solid $(0.058 \mathrm{~g}$, $61 \%$ yield).

${ }^{1} \mathrm{H}$ NMR $\left(\mathrm{CD}_{3} \mathrm{CN}, 600 \mathrm{MHz}\right): \delta 8.60(\mathrm{~d}, J=9.6 \mathrm{~Hz}, 1 \mathrm{H}), 7.87(\mathrm{~d}, J=9.2 \mathrm{~Hz}, 1 \mathrm{H}), 7.79$ (app t, $J$ $=9.2 \mathrm{~Hz}, 1 \mathrm{H}), 7.65(\operatorname{app~t}, J=9.0 \mathrm{~Hz}, 1 \mathrm{H}), 6.34(\mathrm{~s}, 2 \mathrm{H}), 5.48(\mathrm{~s}, 1 \mathrm{H})$.

${ }^{13} \mathrm{C} \mathrm{NMR}\left(\mathrm{CDCl}_{3}, 125 \mathrm{MHz}\right): \delta 167.5,157.2,139.3,135.6,131.8,127.5,125.99,125.4,118.3$.

${ }^{11} \mathrm{~B}$ NMR $\left(\mathrm{CD}_{3} \mathrm{CN}, 193 \mathrm{MHz}\right): \delta 28.1$.

HRMS (ESI-): Calculated for $\mathrm{C}_{9} \mathrm{H}_{7} \mathrm{BO}_{4} \mathrm{Cl}\left([\mathrm{M}+\mathrm{Cl}]^{-}\right), 225.0128$; found 225.0121 . 
HMQC was used to confirm the formation of the 5-exo-dig product. Because ipso B-C resonances are not detected in ${ }^{13} \mathrm{C}$ NMR, the resonance at $\delta=5.48 \mathrm{ppm}$ in the HMQC must be attached to an ipso B-C bond because no ${ }^{13} \mathrm{C}$ NMR signal correlates.

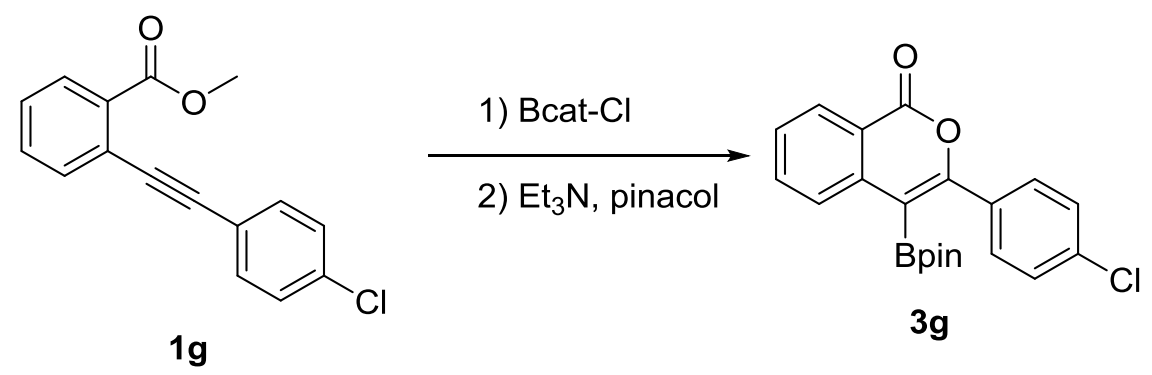

3-(4-chlorophenyl)-4-(4,4,5,5-tetramethyl-1,3,2-dioxaborolan-2-yl)-1H-isochromen-1-one (3g). A vial was charged with $1 \mathrm{~g}(0.135 \mathrm{~g}, 0.500 \mathrm{mmol}, 1.00$ equiv) and $0.5 \mathrm{~mL}$ toluene. A separate vial equipped with a stir bar was charged with $B$-chlorocatecholborane $(0.108 \mathrm{~g}, 0.700$ mmol, 1.40 equiv). The resulting homogenous solution from the first vial was then added dropwise over c.a. 2 min to the boron-containing vial, which stirred for $24 \mathrm{~h}$ at $100{ }^{\circ} \mathrm{C}$. At this time, the reaction mixture was cooled to room temperature and then diluted with $0.5 \mathrm{~mL}$ toluene. A separate vial was then charged with pinacol $\left(0.177 \mathrm{~g}, 1.50 \mathrm{mmol}, 3.00\right.$ equiv) and $\mathrm{Et}_{3} \mathrm{~N}(1.0$ $\mathrm{mL}, 7.5 \mathrm{mmol}, 15$ equiv). The reaction mixture was added dropwise over c.a. 2 min to this vial, and the resulting mixture stirred for $1 \mathrm{~h}$ at room temperature. The solution was concentrated in vacuo and the resulting residue was purified by column chromatography using an elution gradient from $100 \%$ hexanes to $20 \%$ EtOAc/hexanes. Product-containing fractions were combined and concentrated in vacuo, and volatiles were removed at c.a. 10 mTorr for $18 \mathrm{~h}$ to afford $3 \mathrm{~g}$ as a white solid $(0.11 \mathrm{~g}, 60 \%$ yield).

${ }^{1} \mathrm{H} \mathrm{NMR}\left(\mathrm{CDCl}_{3}, 600 \mathrm{MHz}\right): \delta 8.34(\mathrm{~d}, J=7.9 \mathrm{~Hz}, 1 \mathrm{H}), 7.87(\mathrm{~d}, J=7.8 \mathrm{~Hz}, 1 \mathrm{H}), 7.73(\operatorname{app~t}, J=$ $7.7 \mathrm{~Hz}, 1 \mathrm{H}), 7.64-7.62(\mathrm{~m}, 2 \mathrm{H}), 7.52(\operatorname{app~t}, J=7.7 \mathrm{~Hz}, 1 \mathrm{H}), 7.41-7.39(\mathrm{~m}, 2 \mathrm{H}), 1.31(\mathrm{~s}, 12 \mathrm{H})$.

${ }^{13} \mathrm{C} \mathrm{NMR}\left(\mathrm{CDCl}_{3}, 125 \mathrm{MHz}\right): \delta 162.3,158.8,139.5,136.3,135.0,133.2,130.4,129.8,128.5$, 128.3, 126.6, 120.3, 84.7, 25.0.

${ }^{11} \mathrm{~B}$ NMR $\left(\mathrm{CDCl}_{3}, 193 \mathrm{MHz}\right): \delta 31.4$.

HRMS (ESI+): Calculated for $\mathrm{C}_{21} \mathrm{H}_{20} \mathrm{BClO}_{4} \mathrm{Na}\left([\mathrm{M}+\mathrm{Na}]^{+}\right), 405.1045$; found 405.1048 .

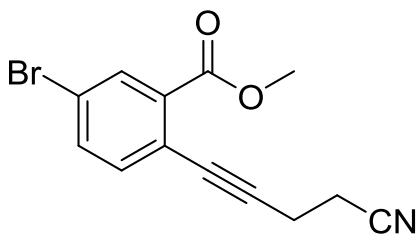

$1 \mathrm{~h}$<smiles>N#CCCc1oc(=O)c2cc(Br)ccc2c1[B]c1ccccc1</smiles>

$3 \mathbf{h}$

3-(7-bromo-1-oxo-4-(4,4,5,5-tetramethyl-1,3,2-dioxaborolan-2-yl)-1H-isochromen-3-

yl)propanenitrile (3h). A vial was charged with $\mathbf{1 h}(0.146 \mathrm{~g}, 0.500 \mathrm{mmol}, 1.00$ equiv) and 0.5 $\mathrm{mL}$ toluene. A separate vial equipped with a stir bar was charged with $B$-chlorocatecholborane (0.108 g, $0.700 \mathrm{mmol}, 1.40$ equiv). The resulting homogenous solution from the first vial was 
then added dropwise over c.a. 2 min to the boron-containing vial, which stirred for $24 \mathrm{~h}$ at 100 ${ }^{\circ} \mathrm{C}$. At this time, the reaction mixture was cooled to room temperature and then diluted with 0.5 $\mathrm{mL}$ toluene. A separate vial was then charged with pinacol $(0.177 \mathrm{~g}, 1.50 \mathrm{mmol}, 3.00$ equiv $)$ and $\mathrm{Et}_{3} \mathrm{~N}$ (1.0 mL, $7.5 \mathrm{mmol}, 15$ equiv). The reaction mixture was added dropwise over c.a. 2 min to this vial, and the resulting mixture stirred for $1 \mathrm{~h}$ at room temperature. The solution was concentrated in vacuo and the resulting residue was purified by column chromatography using an elution gradient from $100 \%$ hexanes to $25 \%$ EtOAc/hexanes. Product-containing fractions were combined and concentrated in vacuo, and volatiles were removed at c.a. 10 mTorr for $18 \mathrm{~h}$ to afford $\mathbf{3 h}$ as a white solid $(0.079 \mathrm{~g}, 39 \%$ yield $)$.

${ }^{1} \mathrm{H} \mathrm{NMR}\left(\mathrm{CDCl}_{3}, 600 \mathrm{MHz}\right): \delta 8.37(\mathrm{~d}, J=2.2 \mathrm{~Hz}, 1 \mathrm{H}), 8.18(\mathrm{~d}, J=8.7 \mathrm{~Hz}, 1 \mathrm{H}), 7.78(\mathrm{dd}, J=$ 8.7, $2.2 \mathrm{~Hz}, 1 \mathrm{H}), 3.26(\mathrm{t}, J=7.4 \mathrm{~Hz}, 2 \mathrm{H}), 2.76(\mathrm{t}, J=7.4 \mathrm{~Hz}, 2 \mathrm{H}), 1.40(\mathrm{~s}, 12 \mathrm{H})$.

${ }^{13} \mathrm{C} \mathrm{NMR}\left(\mathrm{CDCl}_{3}, 125 \mathrm{MHz}\right): \delta 162.3,160.7,138.1,137.7,131.8,129.4,121.8,121.8,118.3$, 84.6, 29.7, 25.0, 16.2.

${ }^{11} \mathrm{~B}$ NMR $\left(\mathrm{CDCl}_{3}, 193 \mathrm{MHz}\right): \delta 30.6$.

HRMS (ESI+): Calculated for $\mathrm{C}_{18} \mathrm{H}_{19} \mathrm{BBrNO}_{4} \mathrm{Na}\left([\mathrm{M}+\mathrm{Na}]^{+}\right), 426.0492$; found 426.0486.

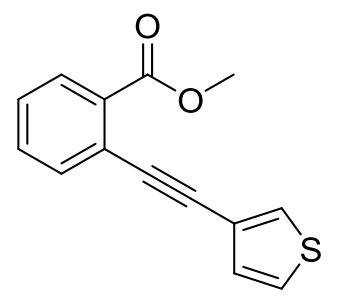

$1 \mathrm{i}$

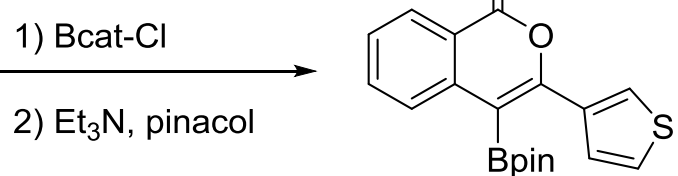

$3 \mathbf{i}$

4-(4,4,5,5-tetramethyl-1,3,2-dioxaborolan-2-yl)-3-(thiophen-3-yl)-1H-isochromen-1-one (3i). A vial was charged with $1 \mathbf{i}(0.177 \mathrm{~g}, 0.500 \mathrm{mmol}, 1.00$ equiv) and $0.5 \mathrm{~mL}$ toluene. A separate vial equipped with a stir bar was charged with $B$-chlorocatecholborane $(0.108 \mathrm{~g}, 0.700 \mathrm{mmol}$, 1.40 equiv). The resulting homogenous solution from the first vial was then added dropwise over c.a. $2 \mathrm{~min}$ to the boron-containing vial, which stirred for $24 \mathrm{~h}$ at $100{ }^{\circ} \mathrm{C}$. At this time, the reaction mixture was cooled to room temperature and then diluted with $0.5 \mathrm{~mL}$ toluene. A separate vial was then charged with pinacol ( $0.177 \mathrm{~g}, 1.50 \mathrm{mmol}, 3.00$ equiv) and $\mathrm{Et}_{3} \mathrm{~N}$ (1.0 mL, $7.5 \mathrm{mmol}, 15$ equiv). The reaction mixture was added dropwise over c.a. 2 min to this vial, and the resulting mixture stirred for $1 \mathrm{~h}$ at room temperature. The solution was concentrated in vacuo and the resulting residue was purified by column chromatography using an elution gradient from 100\% hexanes to $20 \%$ EtOAc/hexanes. Product-containing fractions were combined and concentrated in vacuo, and volatiles were removed at c.a. $10 \mathrm{mTorr}$ for $18 \mathrm{~h}$ to afford $\mathbf{3 i}$ as a white solid $(0.13$ g, $71 \%$ yield).

${ }^{1} \mathrm{H} \mathrm{NMR}\left(\mathrm{CDCl}_{3}, 600 \mathrm{MHz}\right): \delta 8.31(\operatorname{app~d}, J=7.9 \mathrm{~Hz}, 1 \mathrm{H}), 7.78-7.76(\mathrm{~m}, 1 \mathrm{H}), 7.74(\mathrm{dd}, J=$ 8.0, 0.3 Hz, 1H), 7.69 (ddd, $J=7.6,7.6,1.3 \mathrm{~Hz}, 1 \mathrm{H}), 7.46$ (ddd, $J=7.6,7.6,1.1 \mathrm{~Hz}, 1 \mathrm{H}), 7.43$ $7.42(\mathrm{~m}, 1 \mathrm{H}), 7.35-7.33(\mathrm{~m}, 1 \mathrm{H}), 1.34(\mathrm{~s}, 12 \mathrm{H})$.

${ }^{13} \mathrm{C} \mathrm{NMR}\left(\mathrm{CDCl}_{3}, 125 \mathrm{MHz}\right): \delta 162.3,154.5,139.6,135.9,134.8,129.7,127.9,127.7,127.2$, $126.4,125.8,120.2,84.7,25.1$.

${ }^{11} \mathrm{~B}$ NMR $\left(\mathrm{CDCl}_{3}, 193 \mathrm{MHz}\right): \delta 31.8$. 
HRMS (ESI+): Calculated for $\mathrm{C}_{21} \mathrm{H}_{19} \mathrm{BO}_{4} \mathrm{SNa}\left([\mathrm{M}+\mathrm{Na}]^{+}\right)$, 377.0999; found 377.0995.

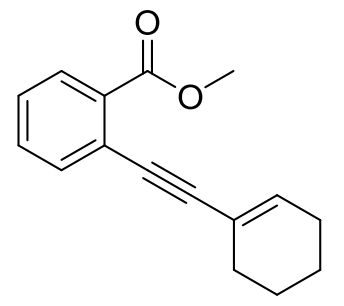

$1 \mathrm{j}$

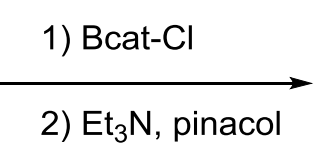

2) $\mathrm{Et}_{3} \mathrm{~N}$, pinacol

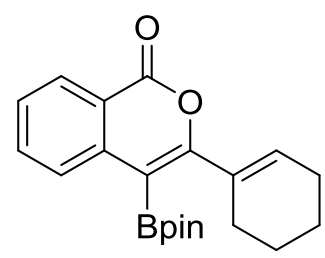

3j

3-(cyclohex-1-en-1-yl)-4-(4,4,5,5-tetramethyl-1,3,2-dioxaborolan-2-yl)-1H-isochromen-1one (3j). A vial was charged with $\mathbf{1 j}(0.120 \mathrm{~g}, 0.500 \mathrm{mmol}, 1.00$ equiv) and $0.5 \mathrm{~mL}$ toluene. A separate vial equipped with a stir bar was charged with $B$-chlorocatecholborane $(0.108 \mathrm{~g}, 0.700$ mmol, 1.40 equiv). The resulting homogenous solution from the first vial was then added dropwise over c.a. 2 min to the boron-containing vial, which stirred for $24 \mathrm{~h}$ at $100{ }^{\circ} \mathrm{C}$. At this time, the reaction mixture was cooled to room temperature and then diluted with $0.5 \mathrm{~mL}$ toluene. A separate vial was then charged with pinacol $\left(0.177 \mathrm{~g}, 1.50 \mathrm{mmol}, 3.00\right.$ equiv) and $\mathrm{Et}_{3} \mathrm{~N}$ (1.0 $\mathrm{mL}, 7.5 \mathrm{mmol}, 15$ equiv). The reaction mixture was added dropwise over c.a. $2 \mathrm{~min}$ to this vial, and the resulting mixture stirred for $1 \mathrm{~h}$ at room temperature. The solution was concentrated in vacuo and the resulting residue was purified by column chromatography using an elution gradient from $100 \%$ hexanes to $20 \%$ EtOAc/hexanes. Product-containing fractions were combined and concentrated in vacuo, and volatiles were removed at c.a. 10 mTorr for $18 \mathrm{~h}$ to afford 3j as a yellow oil (0.14 g, 77\% yield).

${ }^{1} \mathrm{H} \mathrm{NMR}\left(\mathrm{CDCl}_{3}, 600 \mathrm{MHz}\right): \delta 8.25(\operatorname{app~d}, J=7.8 \mathrm{~Hz}, 1 \mathrm{H}), 7.72(\operatorname{app~d}, J=8.0 \mathrm{~Hz}, 1 \mathrm{H}), 7.64$ $($ app td, $J=7.6,1.2 \mathrm{~Hz}, 1 \mathrm{H}), 7.41(\mathrm{app} t \mathrm{t}, J=7.6,1.0 \mathrm{~Hz}, 1 \mathrm{H}), 2.41-2.39(\mathrm{~m}, 2 \mathrm{H}), 7.43-7.42(\mathrm{~m}$, 2H), 2.14-2.12 (m, 2H), 1.74-1.70 (m, 2H), 1.65-1.61 (m, 2H), 1.35 (s, 12H).

${ }^{13} \mathrm{C} \mathrm{NMR}\left(\mathrm{CDCl}_{3}, 125 \mathrm{MHz}\right): \delta 163.0,162.7,139.8,134.6,134.6,132.0,129.5,127.5,126.2$, $120.2,84.2,26.3,25.5,25.0,22.2,21.7$.

${ }^{11} \mathrm{~B} \mathrm{NMR}\left(\mathrm{CDCl}_{3}, 193 \mathrm{MHz}\right): \delta 31.3$.

HRMS (ESI+): Calculated for $\mathrm{C}_{21} \mathrm{H}_{25} \mathrm{BO}_{4} \mathrm{Na}\left([\mathrm{M}+\mathrm{Na}]^{+}\right), 375.1747$; found 375.1744.<smiles>COC(=O)/C=C\C#CCl</smiles>

$1 \mathbf{k}$

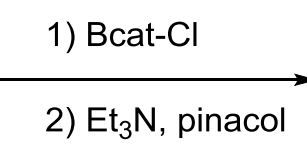<smiles>O=c1ccc(Br)c([18O]Cl)o1</smiles>

3k

6-(6-chlorohexyl)-5-(4,4,5,5-tetramethyl-1,3,2-dioxaborolan-2-yl)-2H-pyran-2-one (3k). A vial was charged with $1 \mathbf{k}(0.179 \mathrm{~g}, 0.780 \mathrm{mmol}, 1.00 \mathrm{equiv})$ and $0.8 \mathrm{~mL}$ toluene. A separate vial equipped with a stir bar was charged with $B$-chlorocatecholborane $(0.170 \mathrm{~g}, 1.10 \mathrm{mmol}, 1.40$ equiv). The resulting homogenous solution from the first vial was then added dropwise over c.a. 2 min to the boron-containing vial, which stirred for $24 \mathrm{~h}$ at $100{ }^{\circ} \mathrm{C}$. At this time, the reaction mixture was cooled to room temperature and then diluted with $0.8 \mathrm{~mL}$ toluene. A separate vial 
was then charged with pinacol (0.272 g, $2.30 \mathrm{mmol}, 3.00$ equiv) and $\mathrm{Et}_{3} \mathrm{~N}$ (1.6 mL, $12 \mathrm{mmol}, 15$ equiv). This mixture was added to the reaction mixture dropwise over c.a. 2 min to this vial, and the resulting mixture stirred for $1 \mathrm{~h}$ at room temperature. The solution was concentrated in vacuo and the resulting residue was purified by column chromatography using an elution gradient from $100 \%$ hexanes to $15 \%$ EtOAc/hexanes. Product-containing fractions were combined and concentrated in vacuo, and volatiles were removed at c.a. 10 mTorr for $18 \mathrm{~h}$ to afford $\mathbf{3 k}$ as a yellow oil that solidified upon standing ( $0.11 \mathrm{~g}, 41 \%$ yield $)$.

${ }^{1} \mathrm{H}$ NMR $\left(\mathrm{CDCl}_{3}, 600 \mathrm{MHz}\right): \delta 7.51(\mathrm{~d}, J=9.4 \mathrm{~Hz}, 1 \mathrm{H}), 6.07(\mathrm{~d}, J=9.4 \mathrm{~Hz}, 1 \mathrm{H}), 3.48(\mathrm{t}, J=6.7$ $\mathrm{Hz}, 2 \mathrm{H}), 2.78(\mathrm{t}, J=7.6 \mathrm{~Hz}, 2 \mathrm{H}), 1.72(\mathrm{M}, 2 \mathrm{H}), 1.64$ (quin, $J=7.6,2 \mathrm{H}), 1.42(\mathrm{t}, J=7.8 \mathrm{~Hz}, 2 \mathrm{H})$, 1.32 (quin, $J=7.5 \mathrm{~Hz}, 2 \mathrm{H}), 1.26(\mathrm{~S}, 12 \mathrm{H})$.

${ }^{13} \mathrm{C} \mathrm{NMR}\left(\mathrm{CDCl}_{3}, 125 \mathrm{MHz}\right): \delta$ 163.0, 162.7, 139.8, 134.6, 134.6, 132.0, 129.5, 127.5, 126.2, $120.2,84.2,26.3,25.5,25.0,22.2,21.7$.

${ }^{11} \mathrm{~B}$ NMR $\left(\mathrm{CDCl}_{3}, 193 \mathrm{MHz}\right): \delta 30.2$.

HRMS (ESI+): Calculated for $\mathrm{C}_{17} \mathrm{H}_{26} \mathrm{ClBO}_{4}\left([\mathrm{M}]^{+}\right)$, 340.1616; found 340.1609.

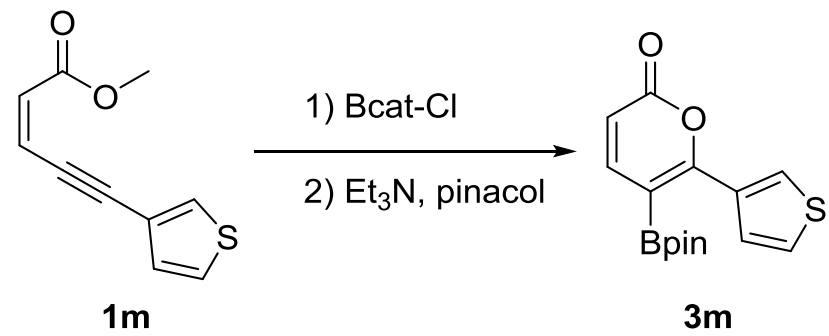

5-(4,4,5,5-tetramethyl-1,3,2-dioxaborolan-2-yl)-6-(thiophen-3-yl)-2H-pyran-2-one (3m). A vial was charged with $1 \mathrm{~m}(0.096 \mathrm{~g}, 0.50 \mathrm{mmol}, 1.0$ equiv) and $0.5 \mathrm{~mL}$ toluene. A separate vial equipped with a stir bar was charged with $B$-chlorocatecholborane $(0.108 \mathrm{~g}, 0.500 \mathrm{mmol}, 1.40$ equiv). The resulting homogenous solution from the first vial was then added dropwise over c.a. $2 \mathrm{~min}$ to the boron-containing vial, which stirred for $21 \mathrm{~h}$ at $100{ }^{\circ} \mathrm{C}$. At this time, the reaction mixture was cooled to room temperature and then diluted with $0.5 \mathrm{~mL}$ toluene. A separate vial was then charged with pinacol $\left(0.177 \mathrm{~g}, 1.50 \mathrm{mmol}, 3.00\right.$ equiv) and $\mathrm{Et}_{3} \mathrm{~N}$ (1.0 mL, $7.5 \mathrm{mmol}, 15$ equiv). This mixture was added to the reaction mixture dropwise over c.a. 2 min to this vial, and the resulting mixture stirred for $1 \mathrm{~h}$ at room temperature. The solution was concentrated in vacuo and the resulting residue was purified by column chromatography using an elution gradient from $100 \%$ hexanes to $20 \%$ EtOAc/hexanes. Product-containing fractions were combined and concentrated in vacuo, and volatiles were removed at c.a. 10 mTorr for $18 \mathrm{~h}$ to afford $\mathbf{3 m}$ as a yellow oil that solidified upon standing $(0.090 \mathrm{~g}, 59 \%$ yield $)$.

${ }^{1} \mathrm{H}$ NMR $\left(\mathrm{CDCl}_{3}, 600 \mathrm{MHz}\right): \delta 8.07(\mathrm{~d}, J=2.1 \mathrm{~Hz}, 1 \mathrm{H}), 7.66(\mathrm{~d}, J=9.4 \mathrm{~Hz}, 1 \mathrm{H}), 7.56(\mathrm{~d}, J=$ $5.0 \mathrm{~Hz}, 1 \mathrm{H}), 7.28$ (dd, $J=5.1,3.0 \mathrm{~Hz}, 1 \mathrm{H}), 6.20(\mathrm{~d}, J=9.4 \mathrm{~Hz}, 1 \mathrm{H}), 1.29(\mathrm{~s}, 12 \mathrm{H})$.

${ }^{13} \mathrm{C} \mathrm{NMR}\left(\mathrm{CDCl}_{3}, 125 \mathrm{MHz}\right): \delta 164.1,161.7,149.6,134.6,129.6,128.1,125.1,112.6,84.6$, 24.8 .

${ }^{11} \mathrm{~B}$ NMR $\left(\mathrm{CDCl}_{3}, 193 \mathrm{MHz}\right): \delta 30.3$.

HRMS (ESI+): Calculated for $\mathrm{C}_{15} \mathrm{H}_{17} \mathrm{BO}_{4} \mathrm{SNa}\left([\mathrm{M}+\mathrm{Na}]^{+}\right), 327.0841$; found 327.0834 . 


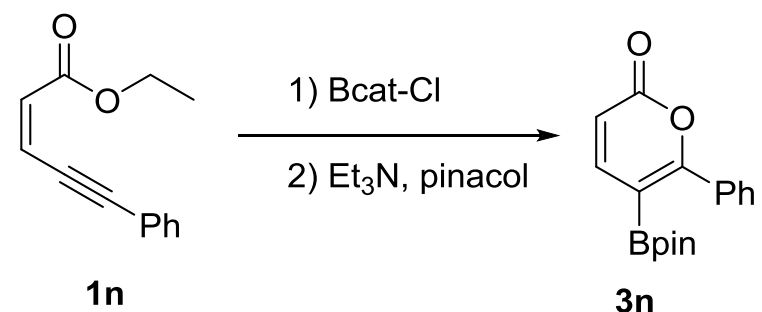

6-phenyl-5-(4,4,5,5-tetramethyl-1,3,2-dioxaborolan-2-yl)-2H-pyran-2-one (3n). A vial was charged with $1 \mathrm{n}(0.070 \mathrm{~g}, 0.35 \mathrm{mmol}, 1.0$ equiv $)$ and $0.4 \mathrm{~mL}$ of toluene. A separate vial equipped with a stir bar was charged with $B$-chlorocatecholborane $(0.075 \mathrm{~g}, 0.49 \mathrm{mmol}, 1.4$ equiv). The resulting homogenous solution from the first vial was then added dropwise over c.a. 2 min to the boron-containing vial, which stirred for $24 \mathrm{~h}$ at $100{ }^{\circ} \mathrm{C}$. At this time, the reaction mixture was cooled to room temperature and then diluted with $0.4 \mathrm{~mL}$ toluene. A separate vial was then charged with pinacol (0.124 g, $1.05 \mathrm{mmol}, 3.00$ equiv) and $\mathrm{Et}_{3} \mathrm{~N}$ (0.70 mL, $5.3 \mathrm{mmol}, 15$ equiv). This mixture was added to the reaction mixture dropwise over c.a. 2 min to this vial, and the resulting mixture stirred for $1 \mathrm{~h}$ at room temperature. The solution was concentrated in vacuo and the resulting residue was purified by column chromatography using an elution gradient from $100 \%$ hexanes to $25 \%$ EtOAc/hexanes. Product-containing fractions were combined and concentrated in vacuo, and volatiles were removed at c.a. 10 mTorr for $18 \mathrm{~h}$ to afford $\mathbf{3 n}$ as a yellow crystalline solid $(0.049 \mathrm{~g}, 47 \%$ yield $)$.

${ }^{1} \mathrm{H} \mathrm{NMR}\left(\mathrm{CDCl}_{3}, 600 \mathrm{MHz}\right): \delta 7.65-7.63(\mathrm{~m}, 3 \mathrm{H}), 7.47(\operatorname{app~t}, J=7.4 \mathrm{~Hz}, 1 \mathrm{H}), 7.39(\operatorname{app~t}, J=$ $7.7 \mathrm{~Hz}, 2 \mathrm{H}), 6.27$ (d, $J=9.3 \mathrm{~Hz}, 1 \mathrm{H}), 1.25$ (s, 12H).

${ }^{13} \mathrm{C} \mathrm{NMR}\left(\mathrm{CDCl}_{3}, 125 \mathrm{MHz}\right): \delta 169.6,162.1,148.9,133.3,131.0,129.5,127.9,113.0,84.5$, 24.7.

${ }^{11} \mathrm{~B} \mathrm{NMR}\left(\mathrm{CDCl}_{3}, 193 \mathrm{MHz}\right): \delta 30.8$.

HRMS (ESI+): Calculated for $\mathrm{C}_{17} \mathrm{H}_{19} \mathrm{BO}_{4} \mathrm{Na}\left([\mathrm{M}+\mathrm{Na}]^{+}\right), 321.1277$; found 321.1283.

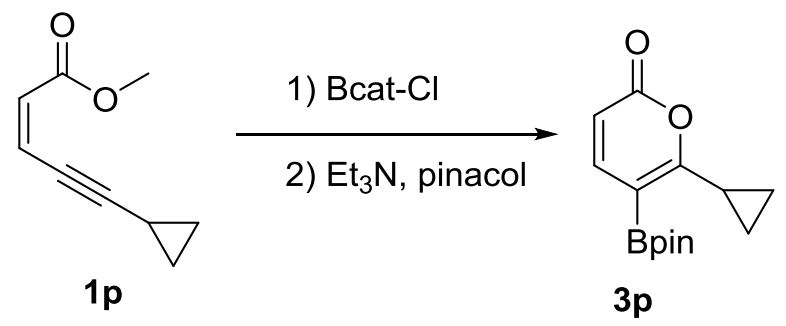

6-cyclopropyl-5-(4,4,5,5-tetramethyl-1,3,2-dioxaborolan-2-yl)-2H-pyran-2-one (3p). A vial was charged with 1p $(0.100 \mathrm{~g}, 0.670 \mathrm{mmol}, 1.00$ equiv $)$ and $0.7 \mathrm{~mL}$ toluene. A separate vial equipped with a stir bar was charged with $B$-chlorocatecholborane $(0.144 \mathrm{~g}, 0.930 \mathrm{mmol}, 1.40$ equiv). The resulting homogenous solution from the first vial was then added dropwise over c.a. $2 \mathrm{~min}$ to the boron-containing vial, which stirred for $24 \mathrm{~h}$ at $100{ }^{\circ} \mathrm{C}$. At this time, the reaction mixture was cooled to room temperature and then diluted with $0.7 \mathrm{~mL}$ toluene. A separate vial was then charged with pinacol $\left(0.237 \mathrm{~g}, 2.01 \mathrm{mmol}, 3.00\right.$ equiv) and $\mathrm{Et}_{3} \mathrm{~N}$ (1.4 mL, 10. mmol, 15 equiv). This mixture was added to the reaction mixture dropwise over c.a. 2 min to this vial, and the resulting mixture stirred for $1 \mathrm{~h}$ at room temperature. The solution was concentrated in vacuo 
and the resulting residue was purified by column chromatography using an elution gradient from $100 \%$ hexanes to $15 \%$ EtOAc/hexanes. Product-containing fractions were combined and concentrated in vacuo, and volatiles were removed at c.a. 10 mTorr for $18 \mathrm{~h}$ to afford $\mathbf{3 p}$ as a yellow solid ( $0.098 \mathrm{~g}, 56 \%$ yield).

${ }^{1} \mathrm{H} \mathrm{NMR}\left(\mathrm{CDCl}_{3}, 600 \mathrm{MHz}\right): \delta 7.52(\mathrm{~d}, J=9.2 \mathrm{~Hz}, 1 \mathrm{H}), 6.00(\mathrm{~d}, J=9.4 \mathrm{~Hz}, 1 \mathrm{H}), 2.73(\mathrm{~m}, 1 \mathrm{H})$, $1.28(\mathrm{~s}, 12 \mathrm{H}), 1.21(\mathrm{~m}, 2 \mathrm{H}), 0.99(\mathrm{~m}, 2 \mathrm{H})$.

${ }^{13} \mathrm{C} \mathrm{NMR}\left(\mathrm{CDCl}_{3}, 125 \mathrm{MHz}\right): \delta 176.3,162.1,149.3,110.4,84.1,24.9,13.9,10.2$.

${ }^{11} \mathrm{~B}$ NMR $\left(\mathrm{CDCl}_{3}, 193 \mathrm{MHz}\right): \delta 30.9$.

HRMS (CI) Calculated for $\mathrm{C}_{14} \mathrm{H}_{19} \mathrm{BO}_{4}\left([\mathrm{M}]^{+}\right), 262.1379$; found 262.1368 .

\section{F. Multigram Scale Preparation of 3g}

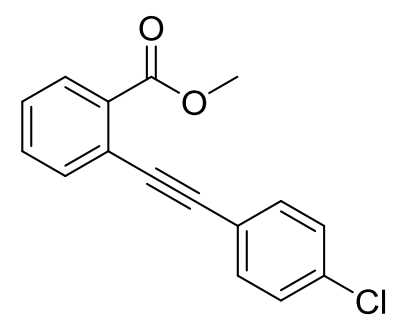

$1 \mathrm{~g}$

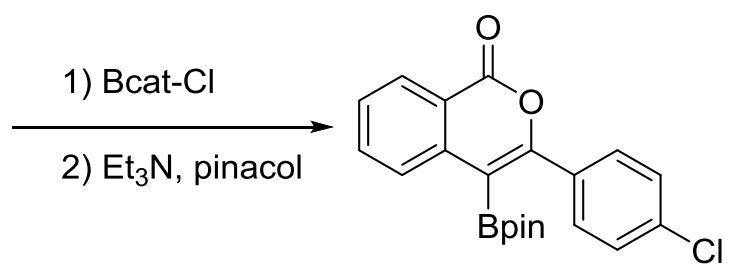

$3 \mathbf{g}$

In a nitrogen-filled glove box, a Schlenk bomb was charged with a solution of $1 \mathrm{~g}(2.50 \mathrm{~g}, 9.23$ mmol, 1.00 equiv) in $4.6 \mathrm{~mL}$ toluene via pipette. A solution of $B$-chlorocatecholborane $(1.99 \mathrm{~g}$, 12.9 mmol, 1.40 equiv) in $4.6 \mathrm{~mL}$ toluene was then added via pipette. The Schlenk bomb was then sealed, brought outside of the glove box, and cooled to $-78{ }^{\circ} \mathrm{C}$ using an isopropanol/dry ice bath. The headspace in the Schlenk bomb was then removed under reduced pressure (c.a. 10 mTorr for $10 \mathrm{sec}$ ) before resealing. The solution was then stirred under static vacuum for $24 \mathrm{~h}$ at $100{ }^{\circ} \mathrm{C}$ in an oil bath. At this time, the reaction mixture was cooled to room temperature and returned to the glove box. A solution of pinacol $\left(3.27 \mathrm{~g}, 27.7 \mathrm{mmol}, 3.00\right.$ equiv) and $\mathrm{Et}_{3} \mathrm{~N}$ (19.2 $\mathrm{mL}, 139 \mathrm{mmol}, 15.0$ equiv) was then added to the reaction mixture over $5 \mathrm{~min}$ and the resulting solution was stirred for $1.5 \mathrm{~h}$ at room temperature. The contents of the Schlenk bomb were then filtered over a bed of celite and rinsed with toluene $(3 \times 20 \mathrm{~mL})$, and the filtrate was concentrated in vacuo. The resulting residue was purified by column chromatography using an elution gradient from $100 \%$ hexanes to $15 \%$ EtOAc/hexanes. Product-containing fractions were combined and concentrated in vacuo, and volatiles were removed at c.a. $10 \mathrm{mTorr}$ for $18 \mathrm{~h}$ to afford $\mathbf{3 g}$ as an off-white solid $(2.5 \mathrm{~g}, 71 \%$ yield). Spectral data were identical to those previously obtained for this compound (see page S20). 


\section{G. Synthesis of 12}

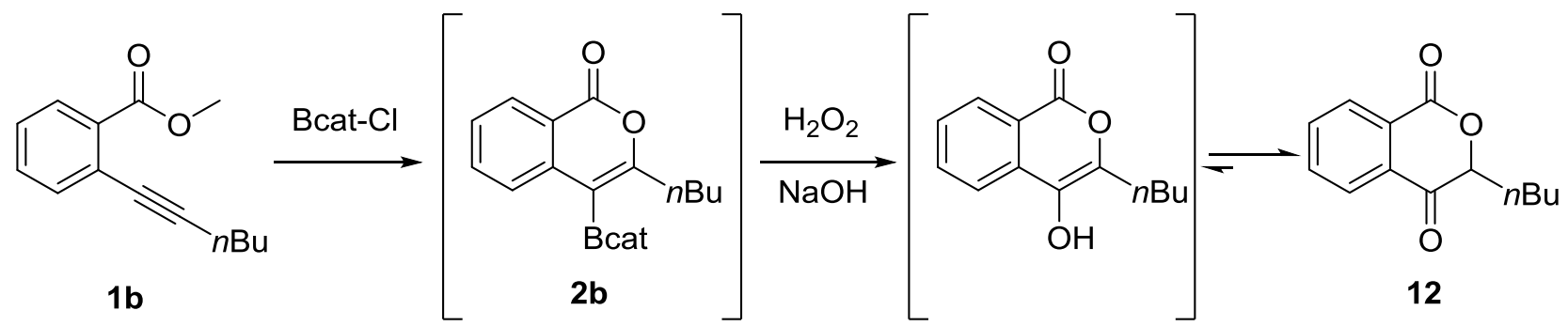

3-butylisochromane-1,4-dione (4). The initial oxyboration step was performed in a $\mathrm{N}_{2}$-filled glove box. A vial was charged with $\mathbf{1 b}(0.108 \mathrm{~g}, 0.500 \mathrm{mmol}, 1.00$ equiv $)$ and $0.5 \mathrm{~mL}$ toluene. A separate vial equipped with a stir bar was charged with $B$-chlorocatecholborane $(0.108 \mathrm{~g}, 0.700$ mmol, 1.40 equiv). The resulting homogenous solution from the first vial was then added dropwise over c.a. 2 min to the boron-containing vial, which stirred for $24 \mathrm{~h}$ at $100{ }^{\circ} \mathrm{C}$. The reaction mixture was then cooled to room temperature and taken out of the glovebox before 1 $\mathrm{mL}$ of methanol, $\mathrm{NaOH}\left(0.30 \mathrm{~mL}\right.$ of a $3.0 \mathrm{M}$ solution, $0.80 \mathrm{mmol}, 1.6$ equiv) and $\mathrm{H}_{2} \mathrm{O}_{2}(82 \mu \mathrm{L}$ of a $30 \mathrm{wt} \%$ solution, $0.80 \mathrm{mmol}, 1.6$ equiv) were added. The reaction mixture was stirred for $2 \mathrm{~h}$, then diluted with $100 \mathrm{~mL}$ EtOAc and washed with $\mathrm{NH}_{4} \mathrm{Cl}(1 \times 20 \mathrm{~mL})$, water $(1 \times 20 \mathrm{~mL})$, brine $(1 \times 20 \mathrm{~mL})$, dried over $\mathrm{Na}_{2} \mathrm{SO}_{4}$, filtered, and concentrated in vacuo. The residue was purified by column chromatography using an elution gradient from $100 \%$ hexanes to $30 \% \mathrm{EtOAc} /$ hexanes. Product-containing fractions were combined and concentrated in vacuo, and volatiles were removed at c.a. 10 mTorr for $18 \mathrm{~h}$ to afford $\mathbf{1 2}$ as a yellow oil. $(0.12 \mathrm{~g}, 56 \%$ yield $)$.

${ }^{1} \mathrm{H}$ NMR $\left(\mathrm{CDCl}_{3}, 600 \mathrm{MHz}\right): \delta 8.27(\mathrm{~m}, 1 \mathrm{H}), 8.06(\mathrm{dd}, J=7.6,1.0 \mathrm{~Hz}, 1 \mathrm{H}), 7.87-7.81(\mathrm{~m}, 2 \mathrm{H})$, 5.09 (dd, $J=7.5 .4 .7 \mathrm{~Hz}, 1 \mathrm{H}), 2.06-1.99(\mathrm{~m}, 2 \mathrm{H}), 1.49-1.44(\mathrm{~m}, 2 \mathrm{H}), 1.39-1.30(\mathrm{~m}, 2 \mathrm{H}), 0.89$ (t, $J=7.3 \mathrm{~Hz}, 3 \mathrm{H})$.

${ }^{13} \mathrm{C} \mathrm{NMR}\left(\mathrm{CDCl}_{3}, 125 \mathrm{MHz}\right): \delta 192.7,162.0,135.7,134.7,131.6,130.7,128.3,126.0,84.6$, 33.8, 26.7, 22.4, 13.9 .

HRMS (ESI+): Calculated for $\mathrm{C}_{13} \mathrm{H}_{18} \mathrm{NO}_{3}\left(\left[\mathrm{M}+\mathrm{NH}_{4}\right]^{+}\right), 236.1287$; found 236.1281 .

\section{H. Suzuki Cross-Coupling of 3g to Generate 13}<smiles>O=c1oc(-c2ccc(Cl)cc2)c(Cc2ccccc2)c2ccccc12</smiles>

$3 g$

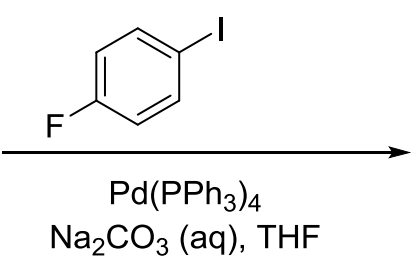

$\mathrm{Na}_{2} \mathrm{CO}_{3}(\mathrm{aq})$, THF<smiles>O=c1oc(-c2ccc(Cl)cc2)c(-c2ccc(F)cc2)c2ccccc12</smiles>

13

3-(4-chlorophenyl)-4-(4-fluorophenyl)-1H-isochromen-1-one (13). This procedure was performed in a $\mathrm{N}_{2}$-filled glove box. A $20 \mathrm{~mL}$ vial was charged with $\mathrm{Pd}\left(\mathrm{PPh}_{3}\right)_{4}(21 \mathrm{mg}, 0.020$ mmol, 0.030 equiv), THF ( $4.0 \mathrm{~mL}), 4$-fluoroiodobenzene $(69 \mu \mathrm{L}, 0.60 \mathrm{mmol}, 1.0$ equiv), $\mathbf{3 g}$ $(0.229 \mathrm{~g}, 0.599 \mathrm{mmol}, 2.00$ equiv), sodium carbonate (1.2 $\mathrm{mL}$ of a $2.0 \mathrm{M}$ aqueous solution, 2.3 
mmol), and a stir bar. The vial was then quickly sealed and brought out of the glove box. The vial was then heated to $75{ }^{\circ} \mathrm{C}$ for $17 \mathrm{~h}$. At this time, TLC (80:20 hex:EtOAc) indicated complete consumption of starting material. The reaction mixture was cooled to room temperature, then diluted with $100 \mathrm{~mL}$ EtOAc and washed with water $(2 \times 20 \mathrm{~mL})$, brine $(1 \times 20 \mathrm{~mL})$, dried over $\mathrm{Na}_{2} \mathrm{SO}_{4}$, filtered, and concentrated in vacuo. The residue was purified by column chromatography using an elution gradient from $100 \%$ hexanes to $20 \%$ EtOAc/hexanes. Productcontaining fractions were combined and concentrated in vacuo, and volatiles were removed at c.a. $10 \mathrm{mTorr}$ for $18 \mathrm{~h}$ to afford 13 as a yellow solid $(0.12 \mathrm{~g}, 58 \%$ yield $)$.

${ }^{1} \mathrm{H} \mathrm{NMR}\left(\mathrm{CDCl}_{3}, 600 \mathrm{MHz}\right): \delta 8.43(\mathrm{~d}, J=7.8 \mathrm{~Hz}, 1 \mathrm{H}), 7.70(\mathrm{t}, J=7.6 \mathrm{~Hz}, 1 \mathrm{H}), 7.58(\mathrm{t}, J=7.5$ $\mathrm{Hz}, 1 \mathrm{H}), 7.29-7.16(\mathrm{~m}, 9 \mathrm{H})$.

${ }^{13} \mathrm{C} \mathrm{NMR}\left(\mathrm{CDCl}_{3}, 125 \mathrm{MHz}\right): \delta 163.7,162.0,161.8,150.2,138.6,135.3,135.0,133.0,132.97$, $130.6,129.9,128.6,128.4,125.3,120.6,116.7,116.5$.

HRMS (ESI+): Calculated for $\mathrm{C}_{21} \mathrm{H}_{12} \mathrm{ClFO}_{2} \mathrm{Na}\left([\mathrm{M}+\mathrm{Na}]^{+}\right), 373.0407$; found 373.0414.

\section{Synthesis of Borylated Isoxazole Product 15}

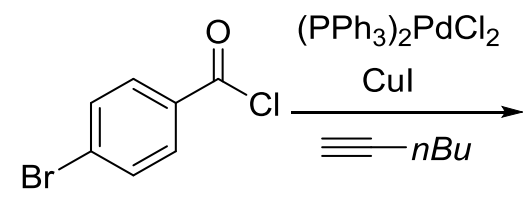

SI-21

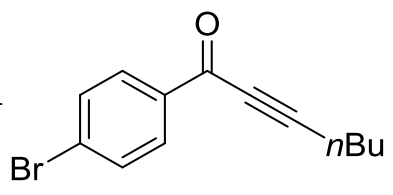

SI-22

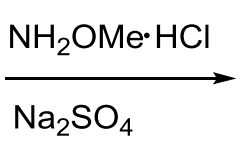

$\mathrm{Br}^{2}$

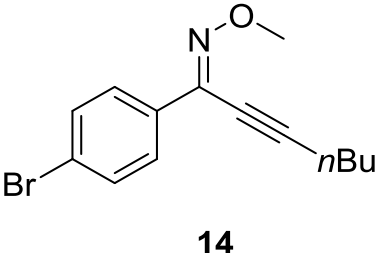

1-(4-bromophenyl)hept-2-yn-1-one (SI-22) was prepared according to a literature procedure ${ }^{16}$ in $86 \%$ yield. ${ }^{1} \mathrm{H} \mathrm{NMR}\left(\mathrm{CDCl}_{3}, 600 \mathrm{MHz}\right): \delta 7.99(\mathrm{~d}, J=8.5 \mathrm{~Hz}, 2 \mathrm{H}), 7.62(\mathrm{~d}, J=8.5 \mathrm{~Hz}, 2 \mathrm{H})$, $2.50(\mathrm{t}, J=7.1 \mathrm{~Hz}, 2 \mathrm{H}$ ), 1.66 (quin, $J=7.3 \mathrm{~Hz}, 2 \mathrm{H}$ ), 1.50 (sxt, $J=7.4 \mathrm{~Hz}, 2 \mathrm{H}$ ), $0.97(\mathrm{t}, J=7.3$ $\mathrm{Hz}, 3 \mathrm{H})$. This spectrum is in agreement with previously reported spectral data. ${ }^{17}$

(Z)-1-(4-bromophenyl)hept-2-yn-1-one $O$-methyl oxime (14) was prepared according to a modified literature procedure. ${ }^{18}$ A round-bottom flask was charged with $\mathrm{H}_{2} \mathrm{NOMe} \cdot \mathrm{HCl}(0.38 \mathrm{~g}$, $4.5 \mathrm{mmol}, 2.0$ equiv), $\mathrm{Na}_{2} \mathrm{SO}_{4}(0.64 \mathrm{~g}, 4.5 \mathrm{mmol}, 2.0$ equiv), and a stir bar. The solids were suspended in $8 \mathrm{~mL}$ of $\mathrm{MeOH}$. Pyridine $(0.68 \mathrm{~mL}, 8.4 \mathrm{mmol}, 3.7$ equiv) and then ketone SI-23 ( $0.60 \mathrm{~g}, 2.3 \mathrm{mmol}, 1.0$ equiv) were consecutively added. The reaction was stirred at $25{ }^{\circ} \mathrm{C}$ for 23 $\mathrm{h}$ without special precautions for oxygen or moisture. The reaction was then quenched with 30 $\mathrm{mL}$ DI water and extracted with EtOAc $(3 \times 60 \mathrm{~mL})$. The combined organic layers were washed with brine $(30 \mathrm{~mL})$, dried over $\mathrm{Na}_{2} \mathrm{SO}_{4}$, filtered, and concentrated in vacuo. The residue was purified by column chromatography using an elution gradient from $100 \%$ hexanes to $40 \%$ DCM/hexanes. Product-containing fractions were combined and concentrated in vacuo to afford 14 as light yellow oil ( $0.27 \mathrm{~g}, 41 \%$ isolated yield $)$.

${ }^{1} \mathrm{H} \mathrm{NMR}\left(\mathrm{CDCl}_{3}, 600 \mathrm{MHz}\right): \delta 7.70(\mathrm{~d}, J=8.5 \mathrm{~Hz}, 2 \mathrm{H}), 7.49(\mathrm{~d}, J=8.5 \mathrm{~Hz}, 2 \mathrm{H}), 4.07(\mathrm{~s}, 3 \mathrm{H})$, $2.54(\mathrm{t}, J=7.2 \mathrm{~Hz}, 2 \mathrm{H}), 1.65$ (quin, $J=7.3 \mathrm{~Hz}, 2 \mathrm{H}), 1.51-1.47(\mathrm{~m}, 2 \mathrm{H}), 0.96(\mathrm{t}, J=7.3 \mathrm{~Hz}, 3 \mathrm{H})$.

${ }^{13} \mathrm{C} \mathrm{NMR}\left(\mathrm{CDCl}_{3}, 125 \mathrm{MHz}\right): \delta 139.4,133.0,131.6,128.1,123.9,104.6,71.2,63.2,30.5,22.2$, 19.6, 13.7 .

HRMS (ESI+): Calculated for $\mathrm{C}_{14} \mathrm{H}_{17} \mathrm{NBrO}\left([\mathrm{M}+\mathrm{H}]^{+}\right)$, 294.0493; found 294.0493. 
<smiles>CCCCC#C/C(=N\OC)c1ccc(Br)cc1</smiles>

14

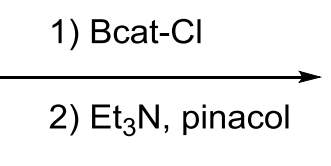

$\mathrm{Br}$<smiles>CCCc1onc(-c2ccc(Br)cc2)c1Cc1ccccc1</smiles>

15

3-(4-bromophenyl)-5-butyl-4-(4,4,5,5-tetramethyl-1,3,2-dioxaborolan-2-yl)isoxazole (15). A vial was charged with $14\left(0.147 \mathrm{~g}, 0.500 \mathrm{mmol}, 1.00\right.$ equiv) and $0.5 \mathrm{~mL} d_{8}$-toluene [Note: the deuterated toluene was used to monitor this unoptimized reaction by ${ }^{1} \mathrm{H}$ and ${ }^{11} \mathrm{~B}$ NMR spectroscopy]. A separate vial was charged with $B$-chlorocatecholborane $(0.108 \mathrm{~g}, 0.700 \mathrm{mmol}$, 1.40 equiv). The resulting homogenous solution from the first vial was then added dropwise over c.a. 2 min to the boron-containing vial, which was then transferred to a J-Young tube via pipette. The tube was then heated to $100{ }^{\circ} \mathrm{C}$ for $48 \mathrm{~h}$, and subsequently to $110{ }^{\circ} \mathrm{C}$ for $48 \mathrm{~h}$. A separate vial was then charged with pinacol $\left(0.177 \mathrm{~g}, 1.50 \mathrm{mmol}, 3.00\right.$ equiv) and $\mathrm{Et}_{3} \mathrm{~N}$ (1.0 mL, $7.5 \mathrm{mmol}, 15$ equiv). The reaction mixture was added dropwise over c.a. 2 min to this vial, and the resulting mixture stirred for $1 \mathrm{~h}$ at room temperature. The solution was concentrated in vacuo and purified by column chromatography using an elution gradient from $100 \%$ hexanes to $40 \%$ DCM/hexanes. Product-containing fractions were combined and concentrated in vacuo, and volatiles were removed at c.a. $10 \mathrm{mTorr}$ for $18 \mathrm{~h}$ to afford 15 as an off-white solid (0.072 $\mathrm{g}, 35 \%$ yield).

${ }^{1} \mathrm{H}$ NMR $\left(\mathrm{CDCl}_{3}, 600 \mathrm{MHz}\right): \delta 7.72(\mathrm{~d}, J=8.4 \mathrm{~Hz}, 2 \mathrm{H}), 7.53(\mathrm{~d}, J=8.4 \mathrm{~Hz}, 2 \mathrm{H}), 3.01(\mathrm{t}, J=$ $7.6 \mathrm{~Hz}, 2 \mathrm{H}$ ), 1.71 (quin, $J=7.5 \mathrm{~Hz}, 2 \mathrm{H}), 1.41-1.37(\mathrm{~m}, 2 \mathrm{H}), 1.29(\mathrm{~s}, 12 \mathrm{H}), 0.94$ (t, $J=7.4 \mathrm{~Hz}$, $3 \mathrm{H})$.

${ }^{13} \mathrm{C} \mathrm{NMR}\left(\mathrm{CDCl}_{3}, 125 \mathrm{MHz}\right): \delta 183.3,165.2,131.3,130.7,129.2,123.8,83.8,30.6,27.0,24.8$, 22.3, 13.8 .

${ }^{11} \mathrm{~B}$ NMR $\left(\mathrm{CDCl}_{3}, 193 \mathrm{MHz}\right): \delta 29.9$.

HRMS (ESI+): Calculated for $\mathrm{C}_{19} \mathrm{H}_{25} \mathrm{NBBrO}_{3}\left([\mathrm{M}]^{+}\right)$, 405.1115 ; found 405.1107 .

J. Procedure for ${ }^{1} \mathbf{H}$ NMR observation of the rate of demethylation of methyl 2iodobenzoate 10<smiles>CCOC(=O)c1ccccc1I</smiles>

This procedure was performed in a $\mathrm{N}_{2}$-filled glove box. A $4 \mathrm{~mL}$ vial was charged with $B$ chlorocatecholborane $(0.108 \mathrm{~g}, 0.700 \mathrm{mmol}, 1.40 \mathrm{equiv})$ and $0.5 \mathrm{~mL}$ of $d_{8}$-toluene. To this vial was sequentially added $10(75 \mu \mathrm{L}, 0.50 \mathrm{mmol}, 1.0$ equiv $)$ and 1,3,5-triisopropylbenzene $(40 . \mu \mathrm{L}$, $0.17 \mathrm{mmol}, 0.33$ equiv) via syringe. The contents of this vial were then transferred to a J-young tube, which was sealed, and then removed from the glove box. Single scan ${ }^{1} \mathrm{H}$ and ${ }^{11} \mathrm{~B}$ NMR spectra were taken at time points $t=0 \mathrm{~h}, 18 \mathrm{~h}$, and $24 \mathrm{~h}$. The resonances corresponding to 10 
were compared to the internal standard to determine the percent of $\mathbf{1 0}$ remaining at $t=24 \mathrm{~h}$ (>95\% 10 remaining at $24 \mathrm{~h}$ ).

\section{References}

1. Shi, C.; Zhang, Q.; Wang, K. K. J. Org. Chem. 1999, 64, 925-932.

2. Yao, T.; Larock, R. C. J. Org. Chem. 2003, 68, 5936-5942.

3. Drox, A. S.; Neidlein, U.; Anderson, S.; Seiler, P.; Dierderich, F. Helv. Chim. Act. 2001, 81, 2243-2289.

4. Duclos, S.; Stoeckli-Evans, H.; Ward, T. R. Helv. Chim. Act. 2001, 84, 3148-3161.

5. Saurabh, M.; Waldo, J. P.; Larock, R. C. J. Org. Chem. 2009, 74, 1141-1147.

6. Marchal, E.; Uriac, P.; Legouin, B.; Toupet, L.; van de Weghe, P. Tetrahedron 2007, 63, 9979-9990.

7. Hellal, M.; Bourguignon, J.-J.; Bihel, F. J.-J. Tetrahedron Lett. 2008, 49, 62-65.

8. Zhang, Q.; Shi, C.; Zhang, H.; Wang, K. K. J. Org. Chem. 2000, 65, 7977-7983.

9. Spino, C.; Rezaei, H.; Dupont-Gaudet, K.; Belanger, F. J. Am. Chem. Soc. 2004, 126, 99269927.

10. Paterson, I.; Paquet, T. Org. Lett. 2010, 12, 2158-2161.

11. Bates, C. G.; Pranorm, S.; Venkataraman, D. Org. Lett. 2004, 6, 1441-1444.

12. Tovar, J. D.; Swager, T. M. J. Org. Chem. 1999, 64, 6499-6504.

13. Zhdankin, V. V.; Koposov, A. Y.; Litinov, D. N.; Ferguson, M. J.; McDonald, R.; Luu, T.;

Tykwinski, R. R. J. Org. Chem. 2005, 70, 6484-6491.

14. Kusama, H.; Funami, H.; Takaya, J.; Iasawa, N. Org. Lett. 2004, 6, 605-608.

15. Park, J. H.; Bhilare, S. V.; Youn, S. W. Org. Lett. 2011, 13, 2228-2231.

16. Karpov, A. S.; Müller, T. J. J. Org. Lett. 2003, 5, 3451-3454.

17. Natte, K.; Chen, J.; Neumann, H.; Beller, M.; Wu, X-F. Org. Biomol. Chem. 2014, 12, 55905593.

18. Jeong, Y.; Kim, B-I.; Lee, J. K.; Ryu, J-S. J. Org. Chem. 2014, 79, 6444-6455.

\section{NMR Spectra}




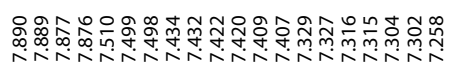

NiñNNANNANNANAN

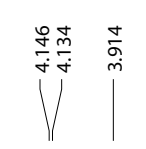

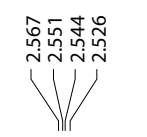

$V^{\substack{9.20 \\ 0.20}}$
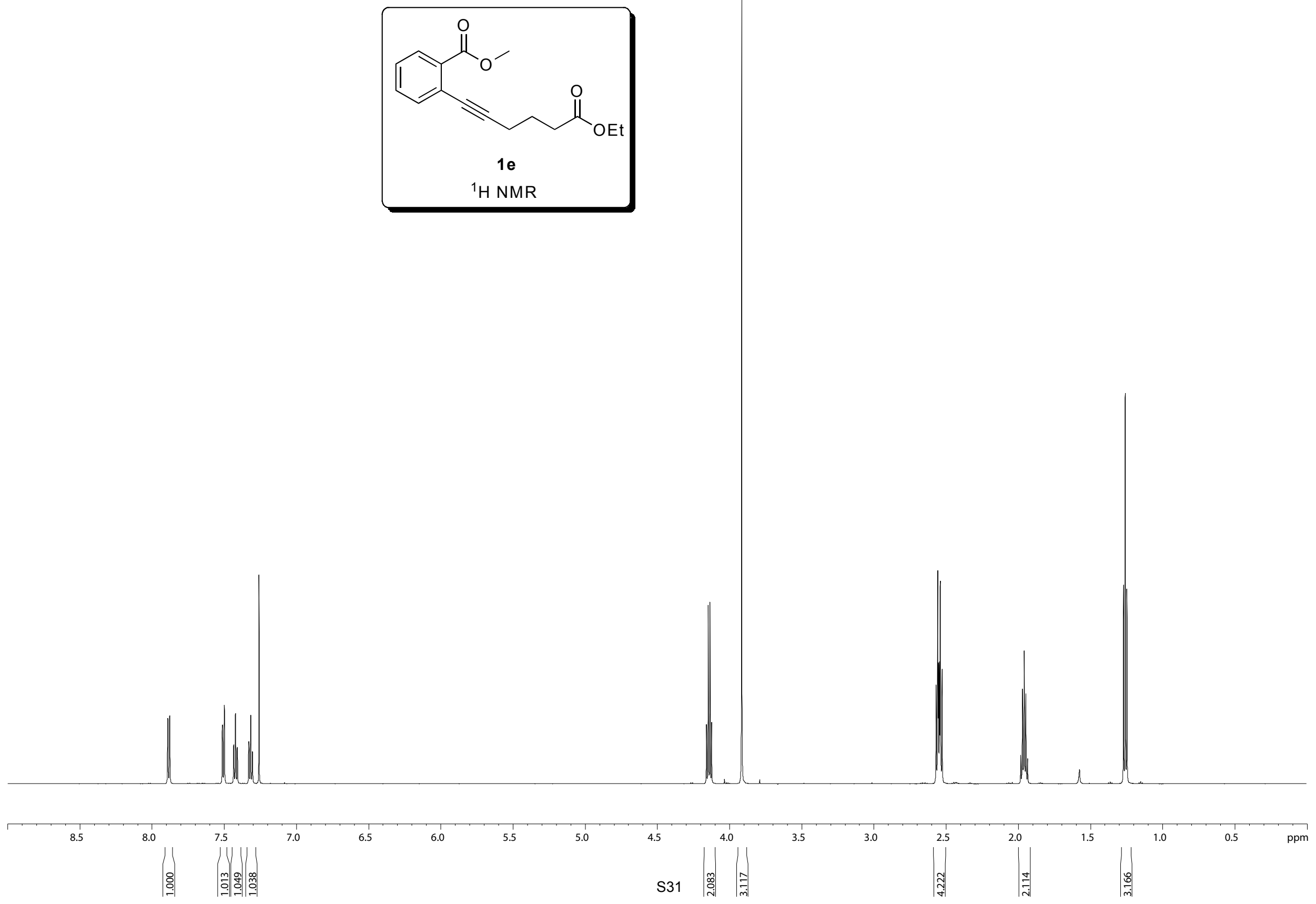


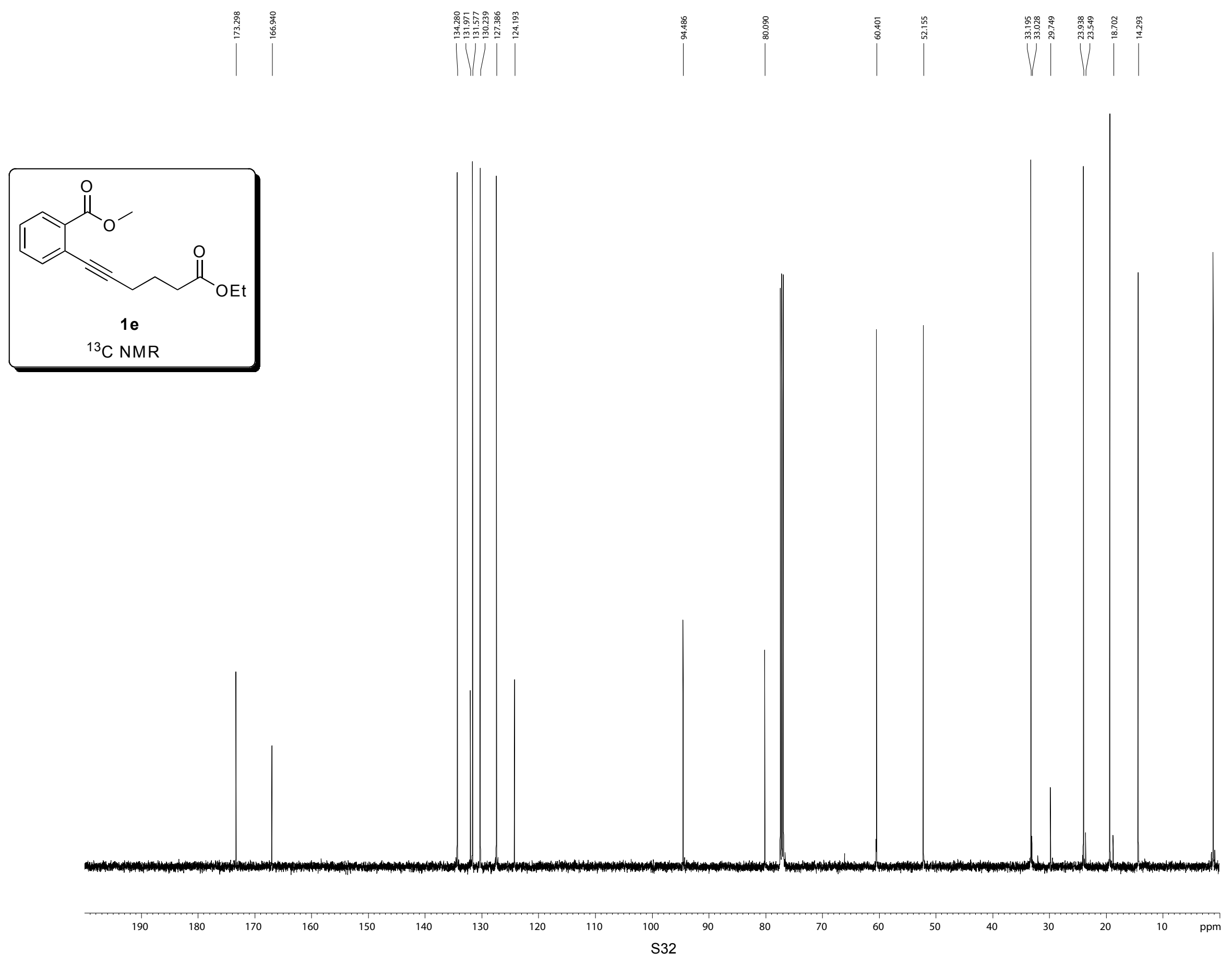




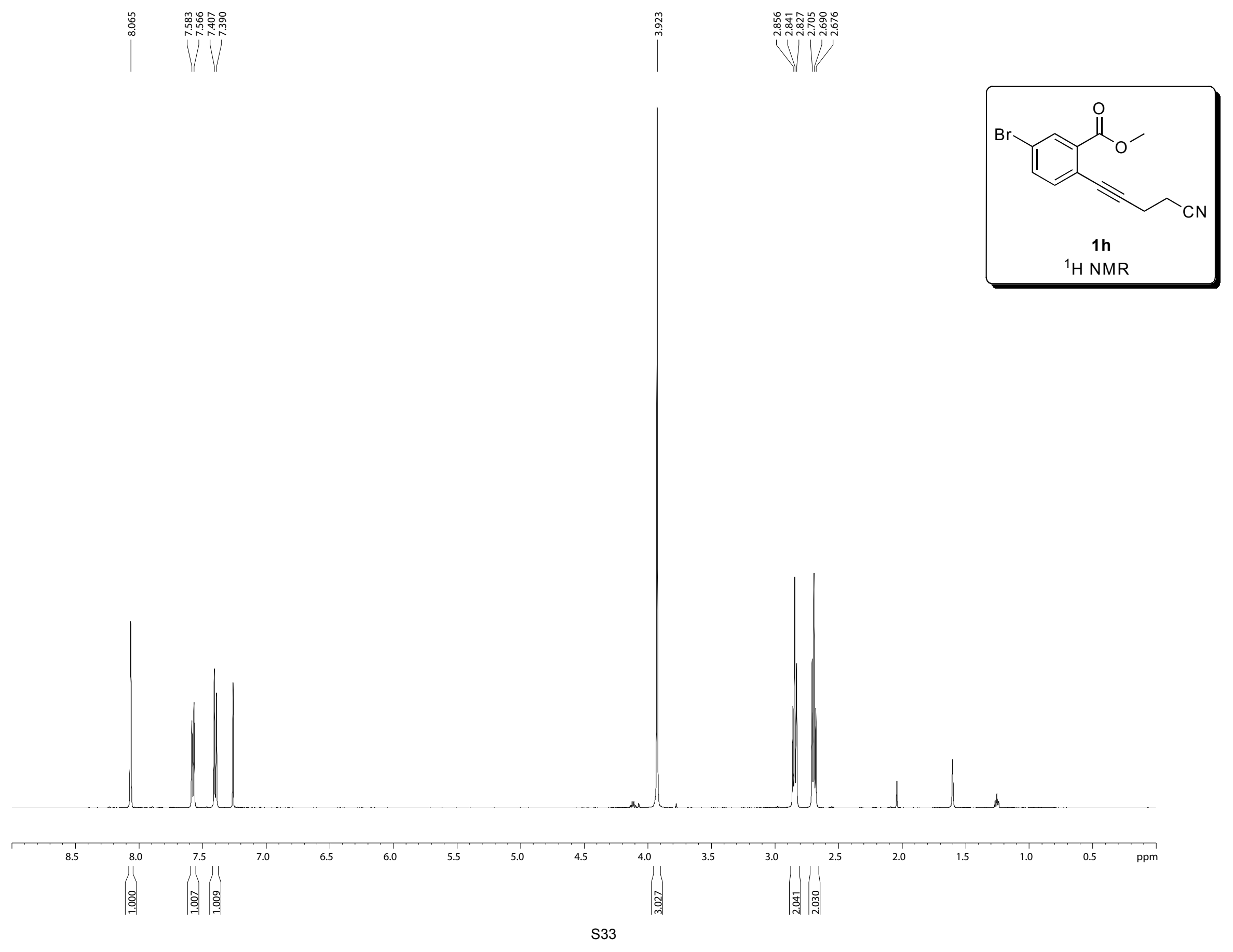



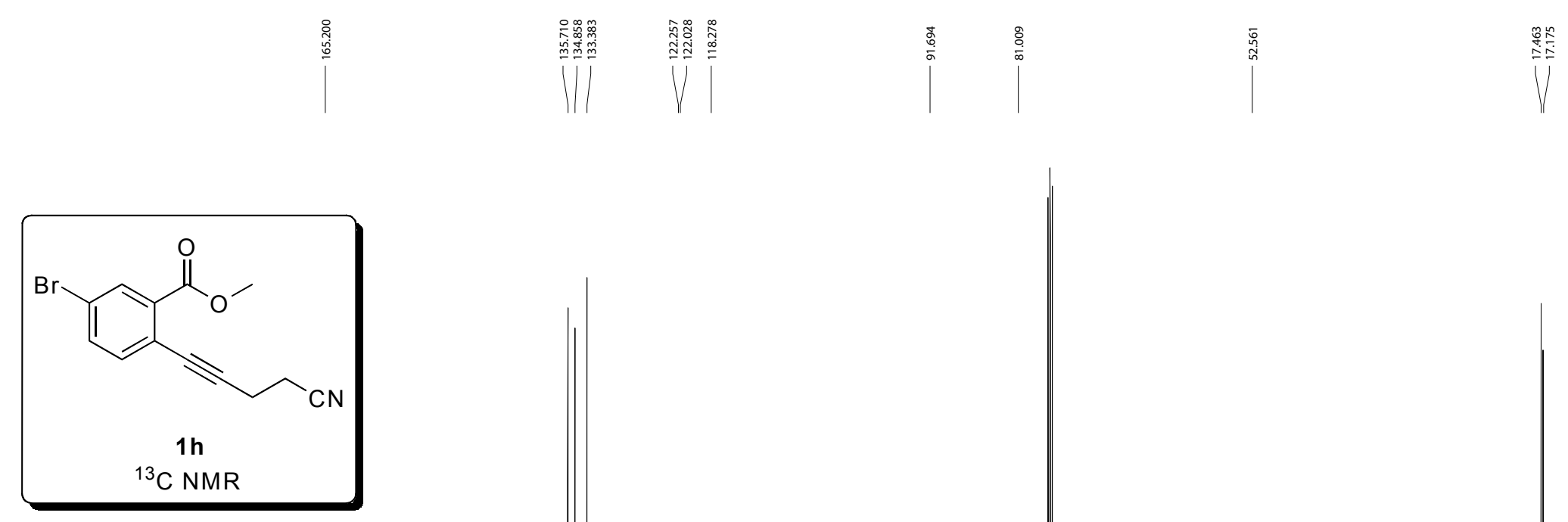

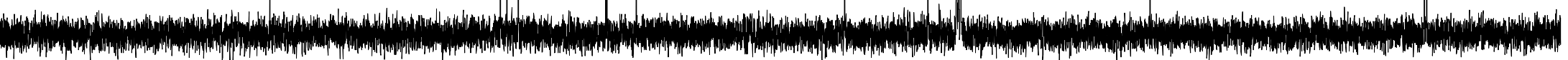
180 170 160 150 140 120 100 S34 


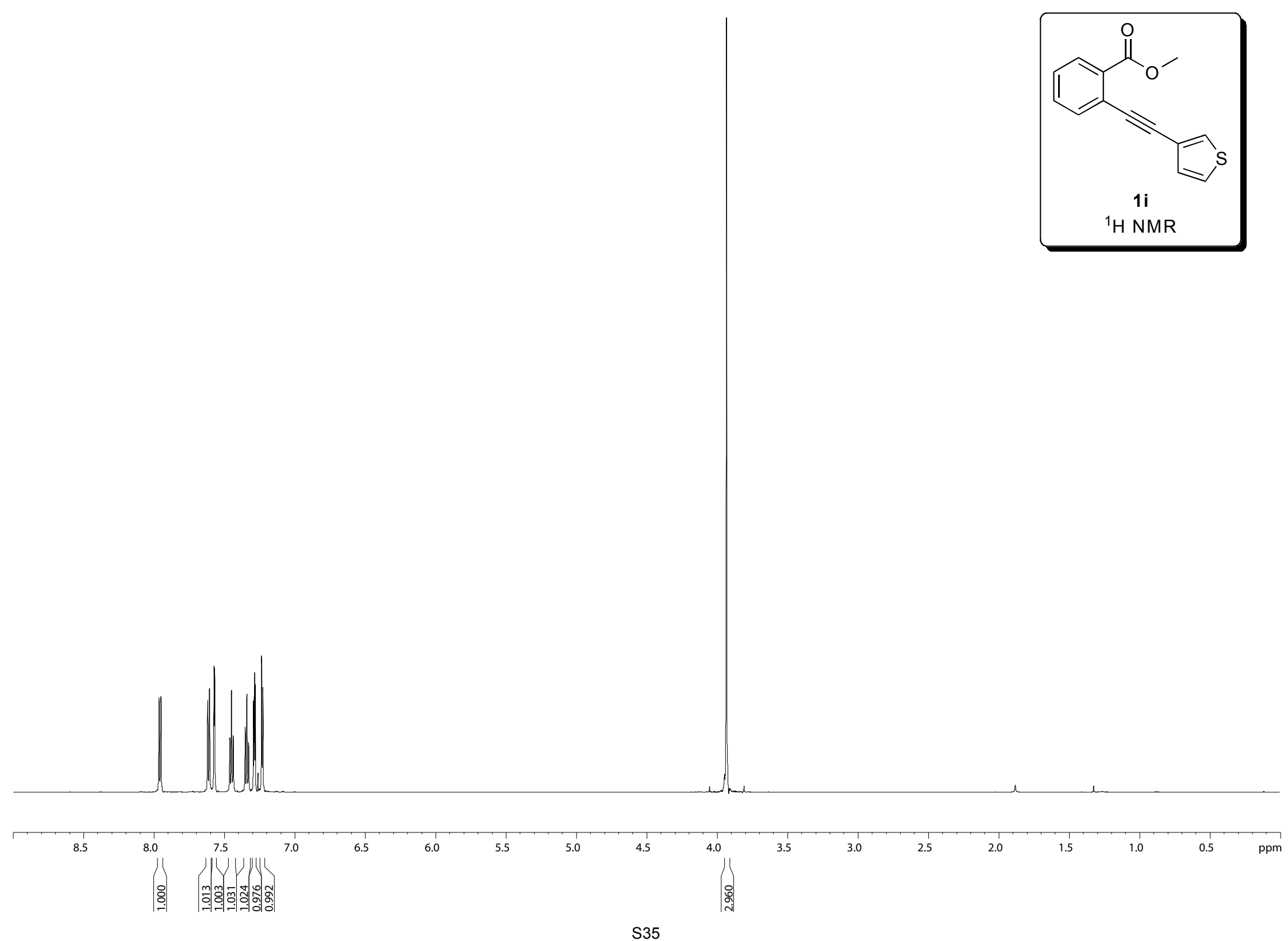




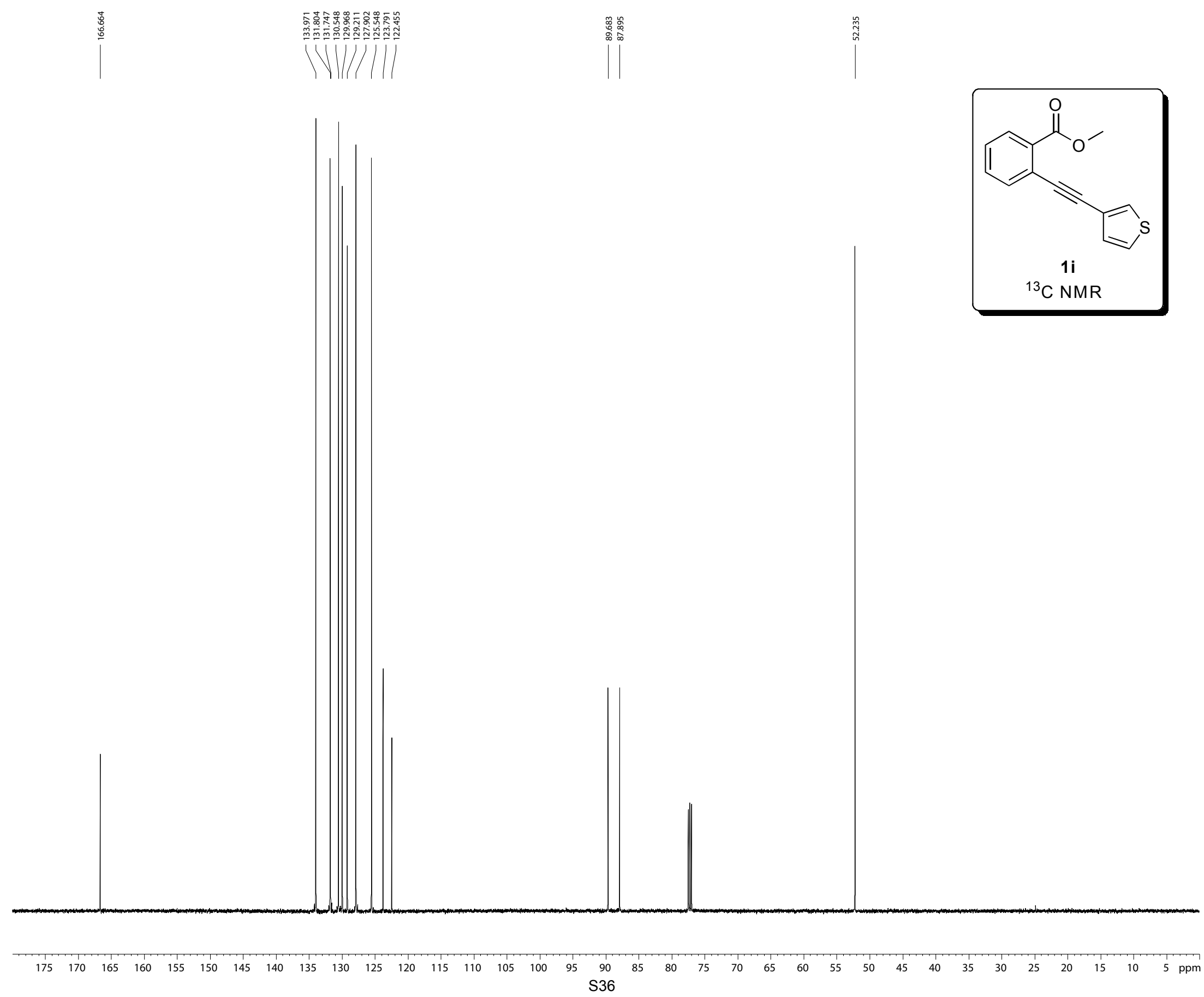




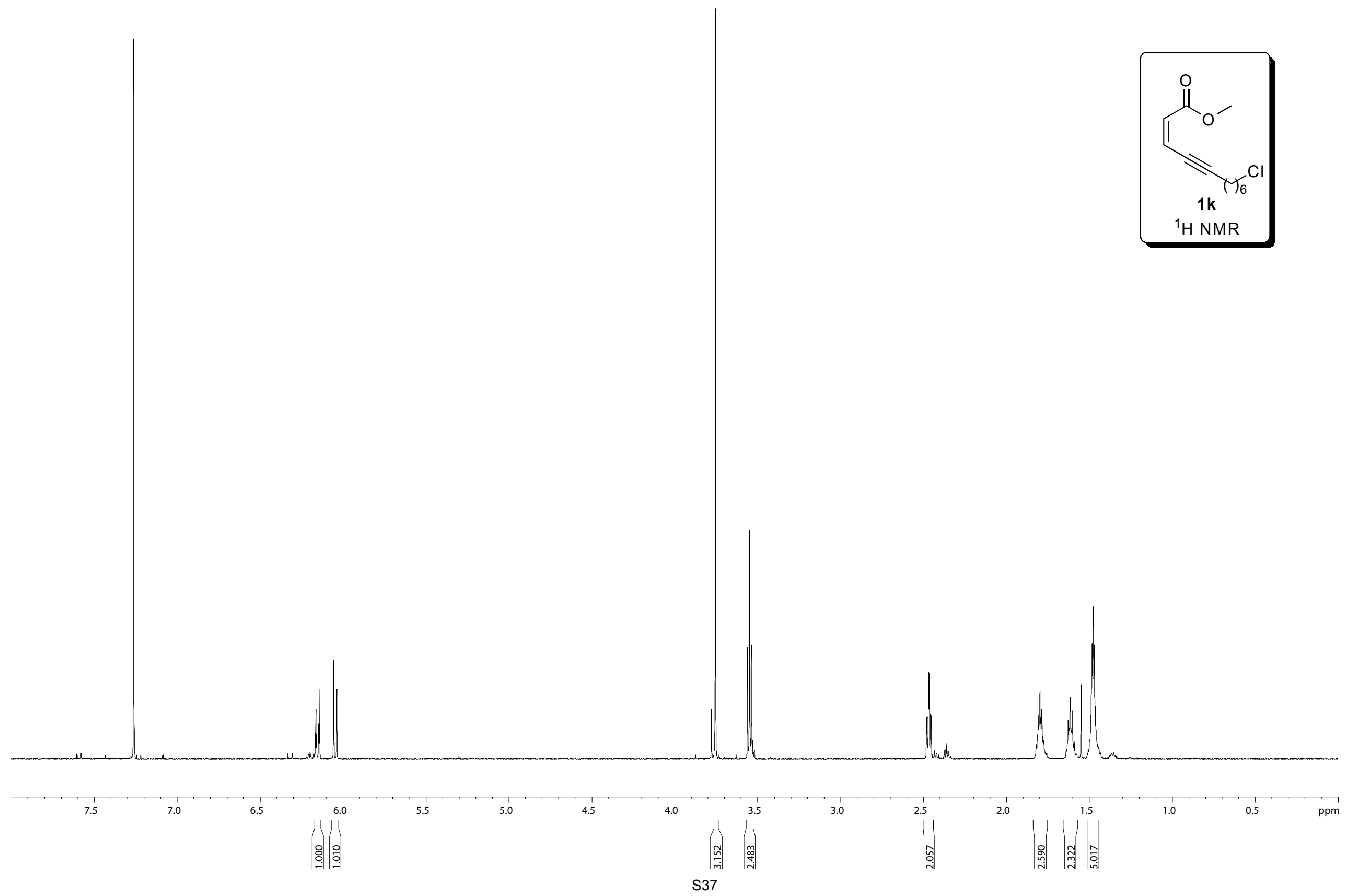




$\mid$
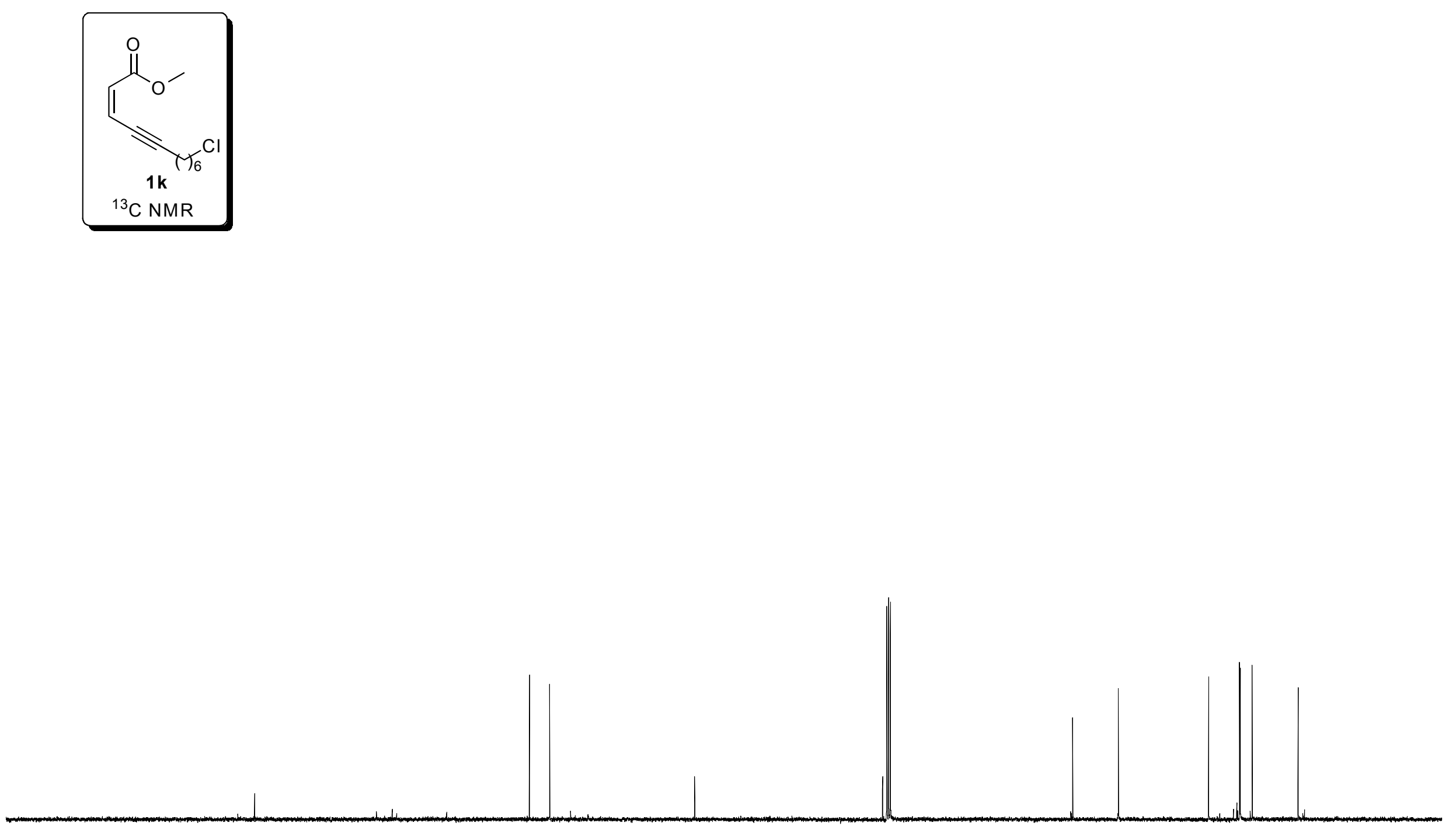

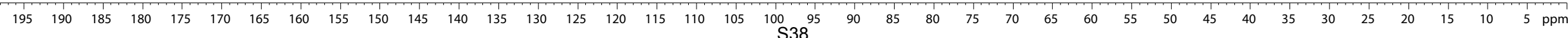




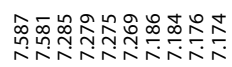

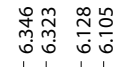

ivilij

11

$\left.\right|^{\stackrel{0}{\infty}}$

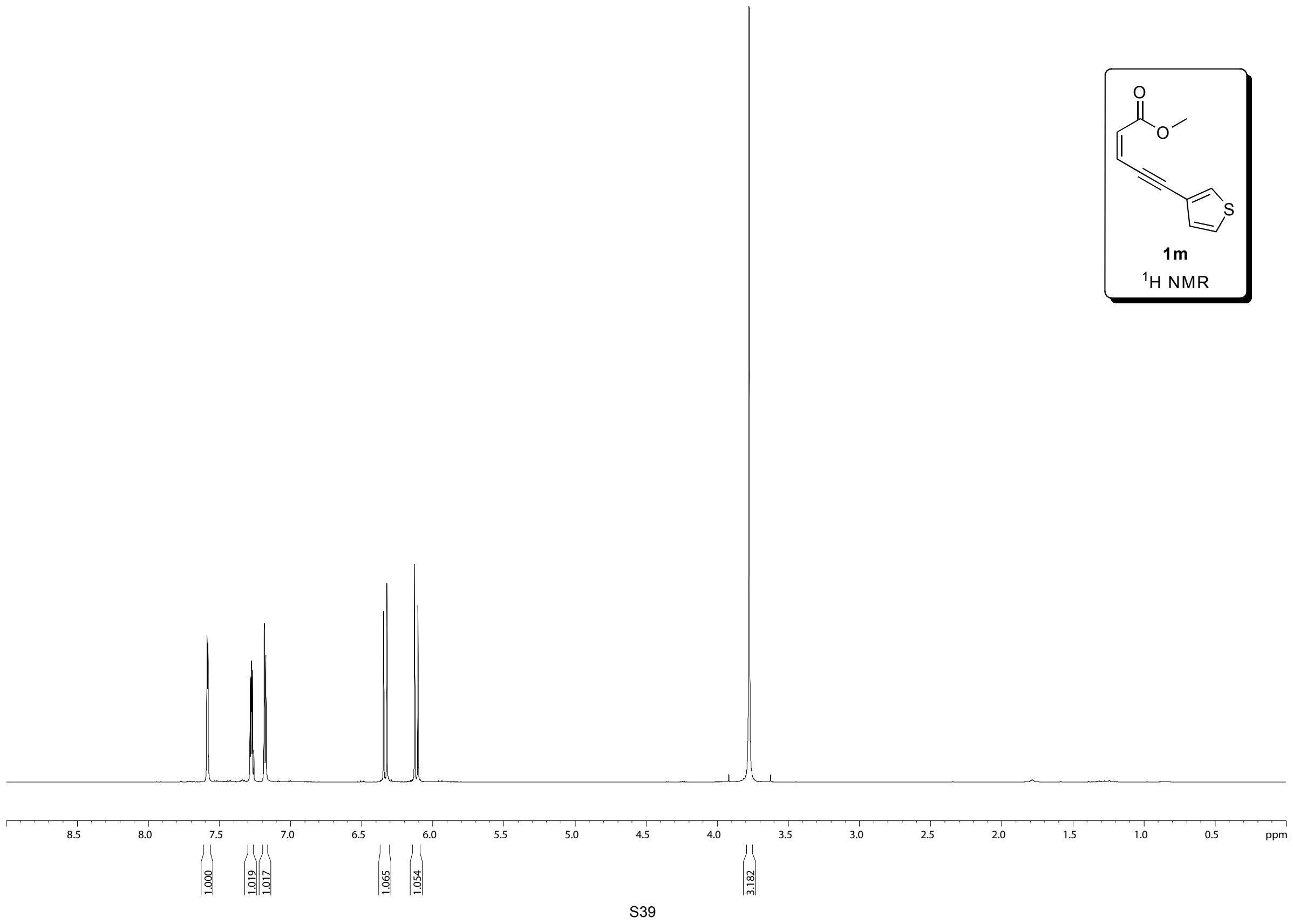




$\mid$
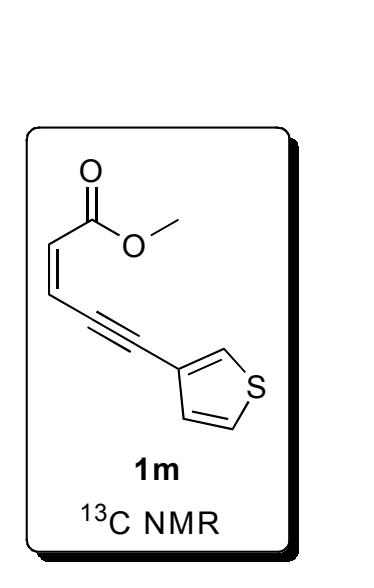


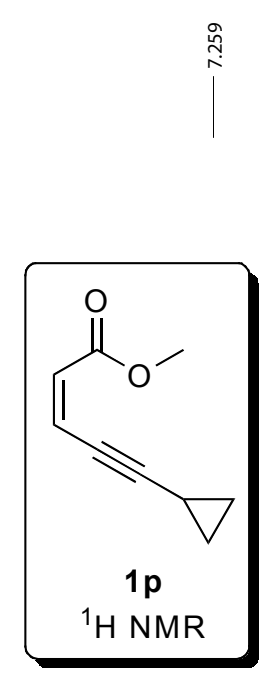

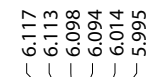

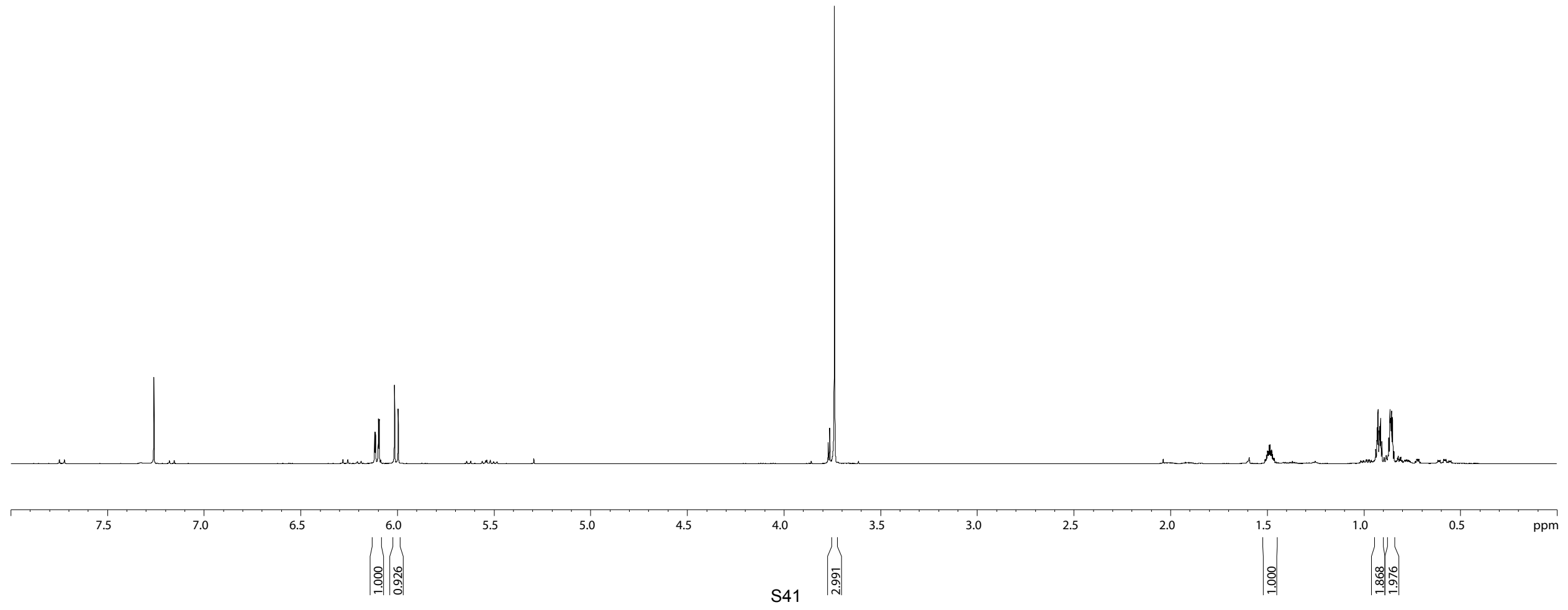



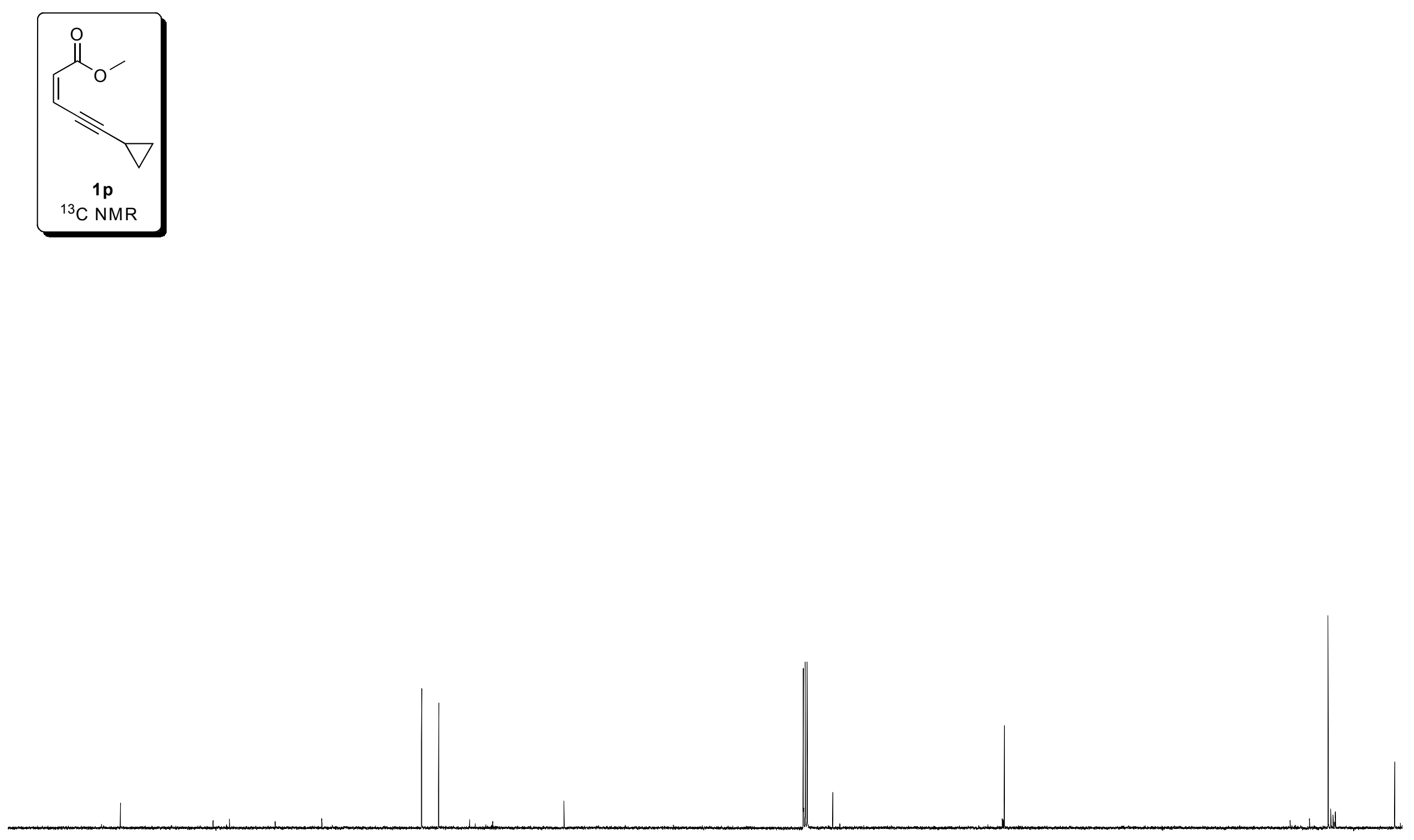


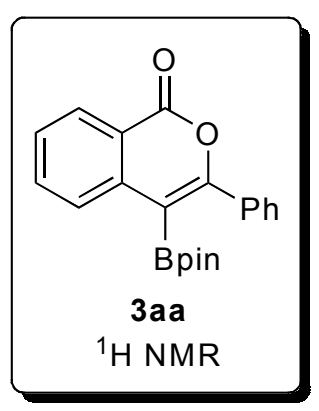

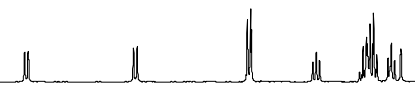
1

4.0

3.5

3.0

2.5 $\stackrel{m}{2.0}$

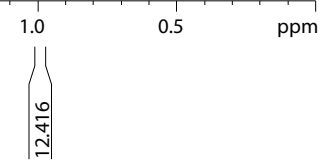


V

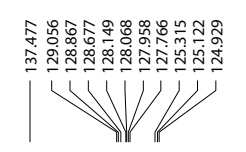

离

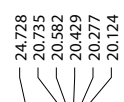
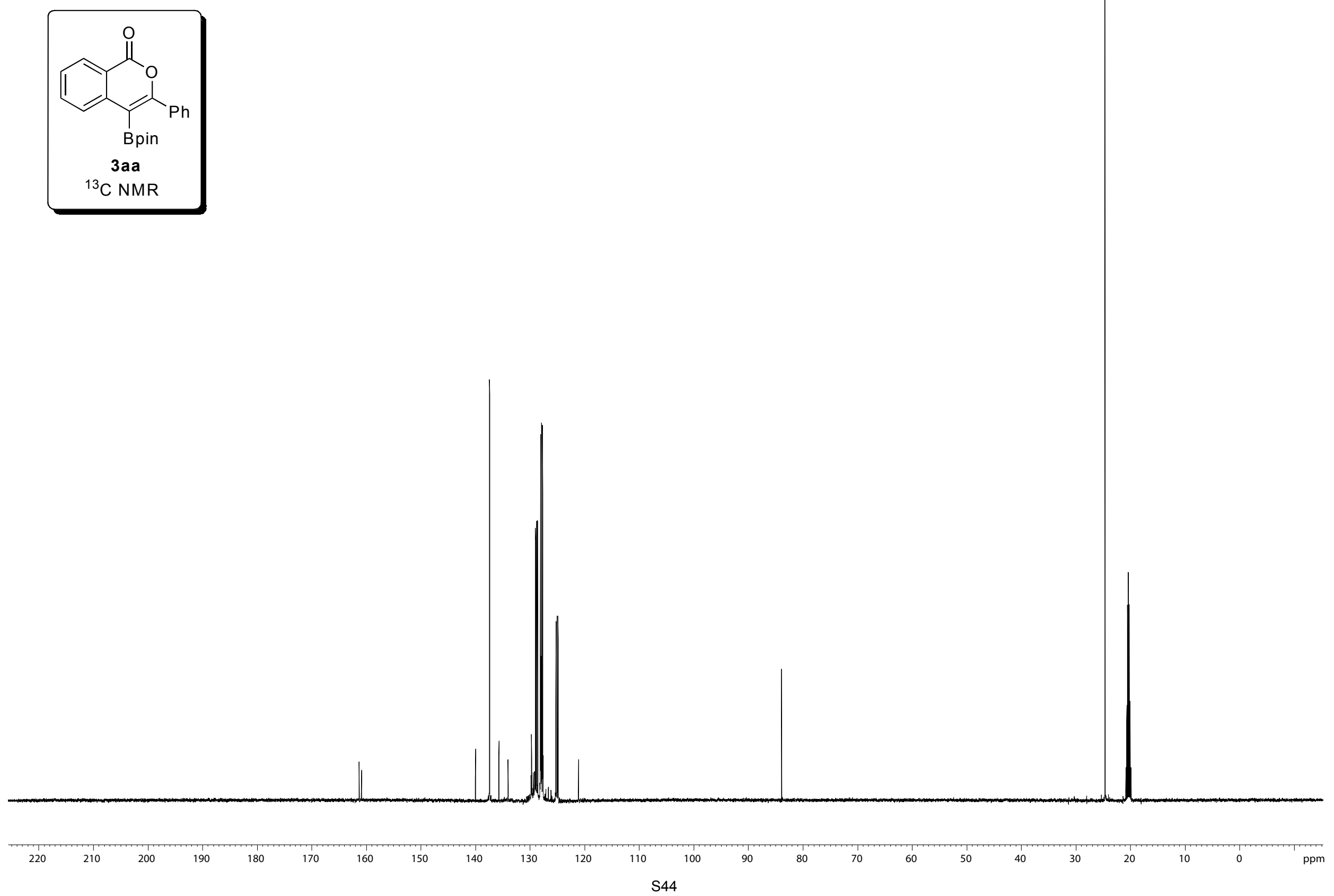


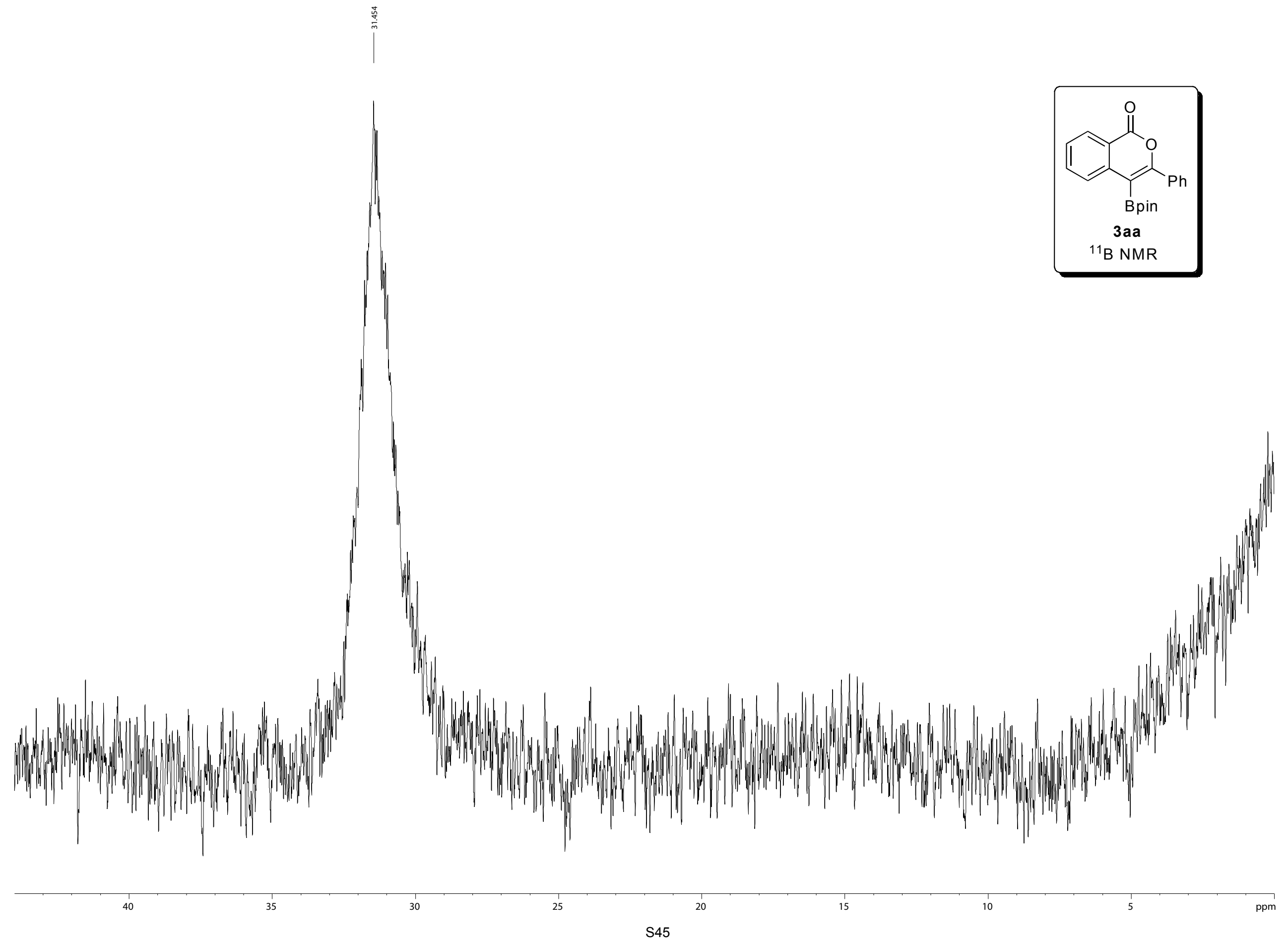



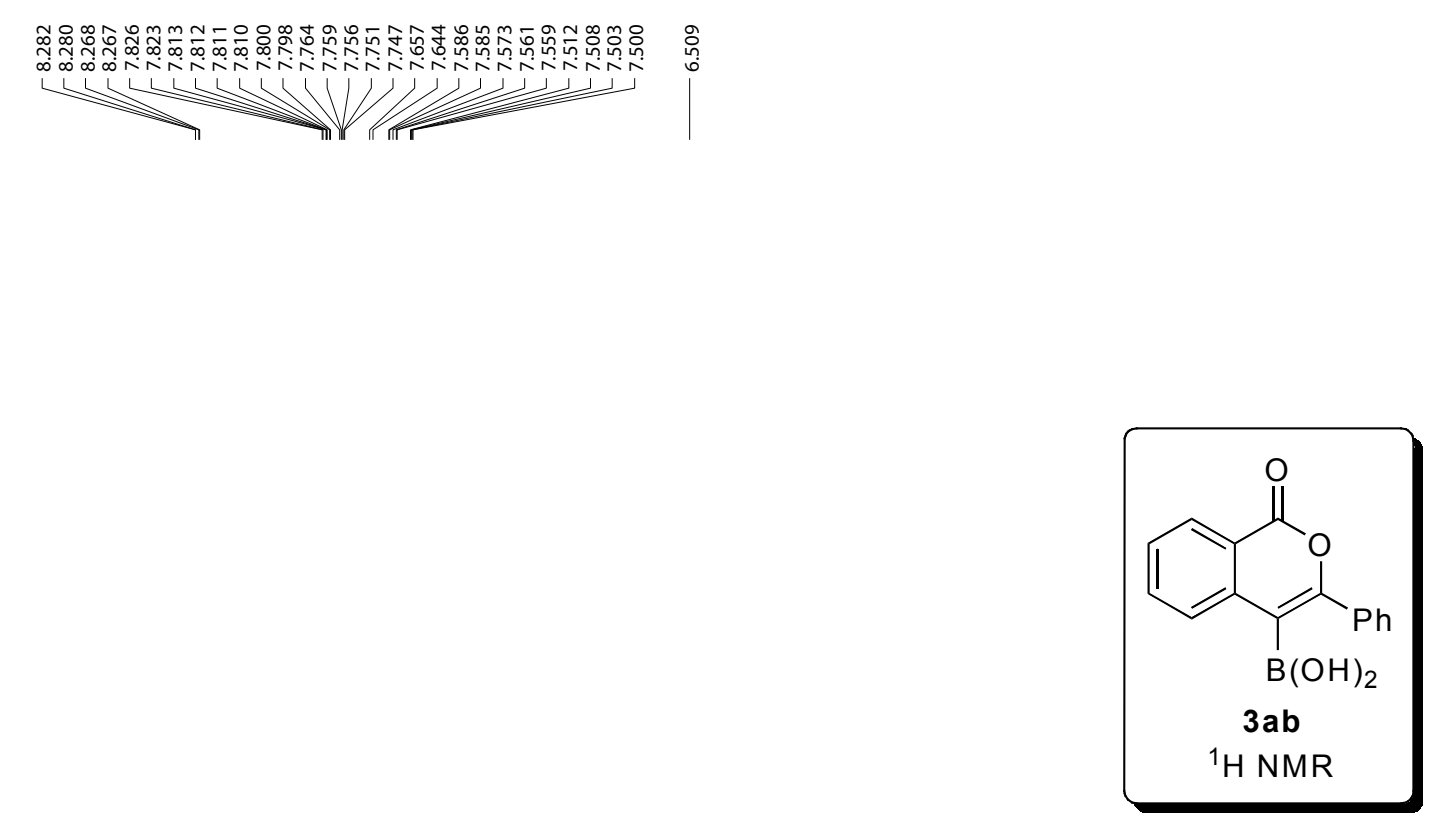


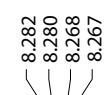

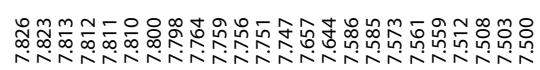

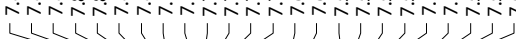

suY WH II VIIII)
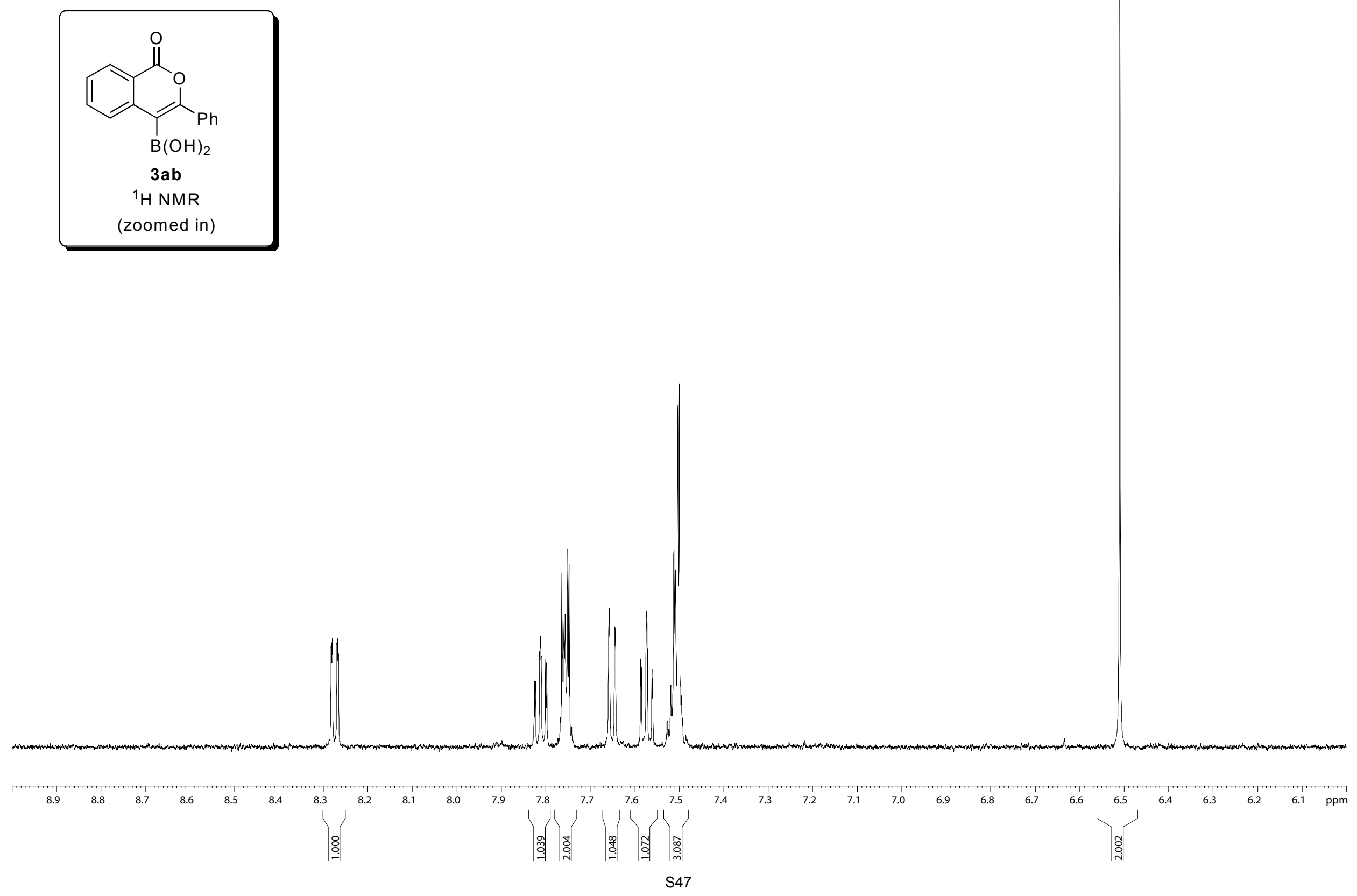


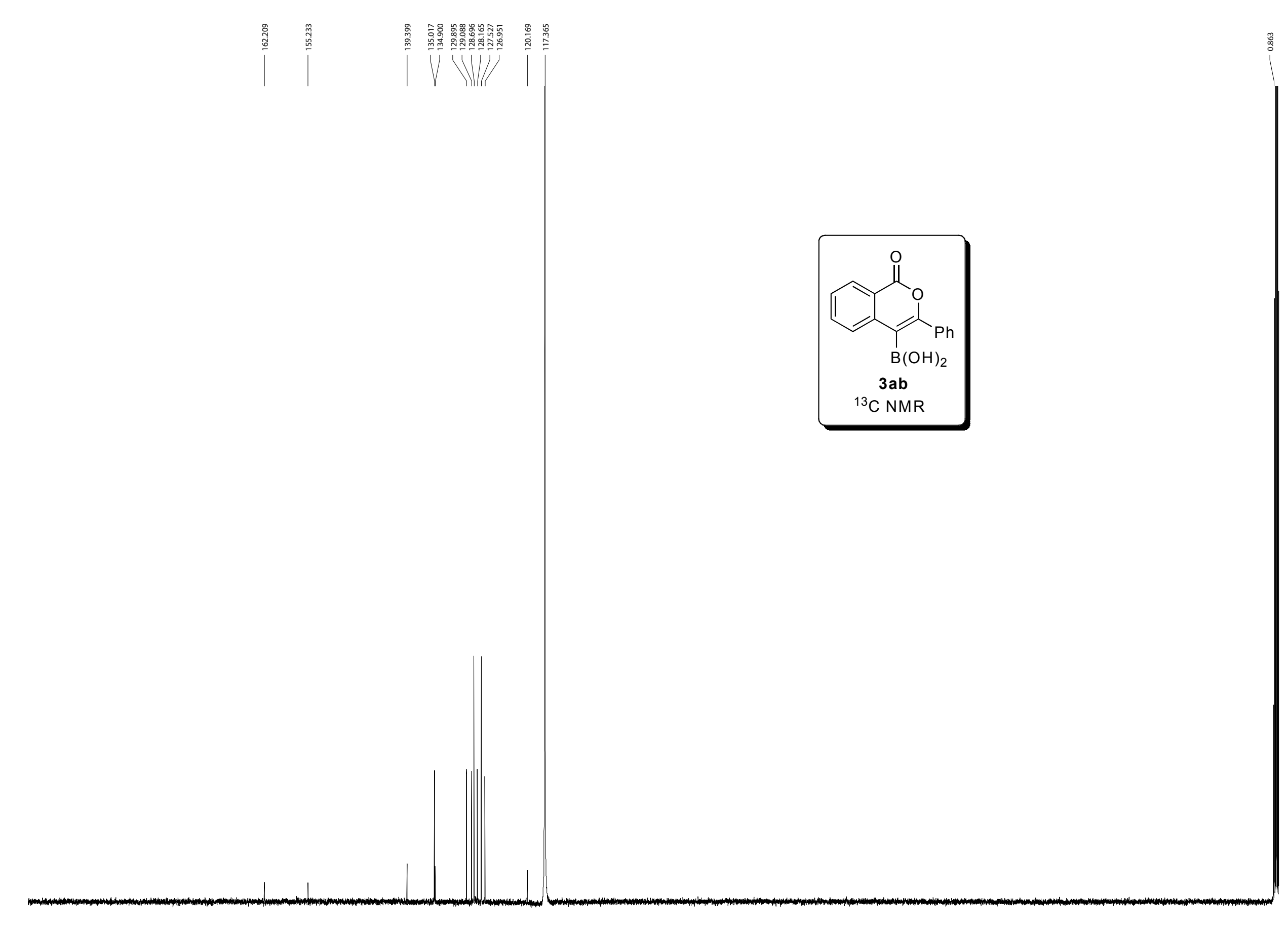



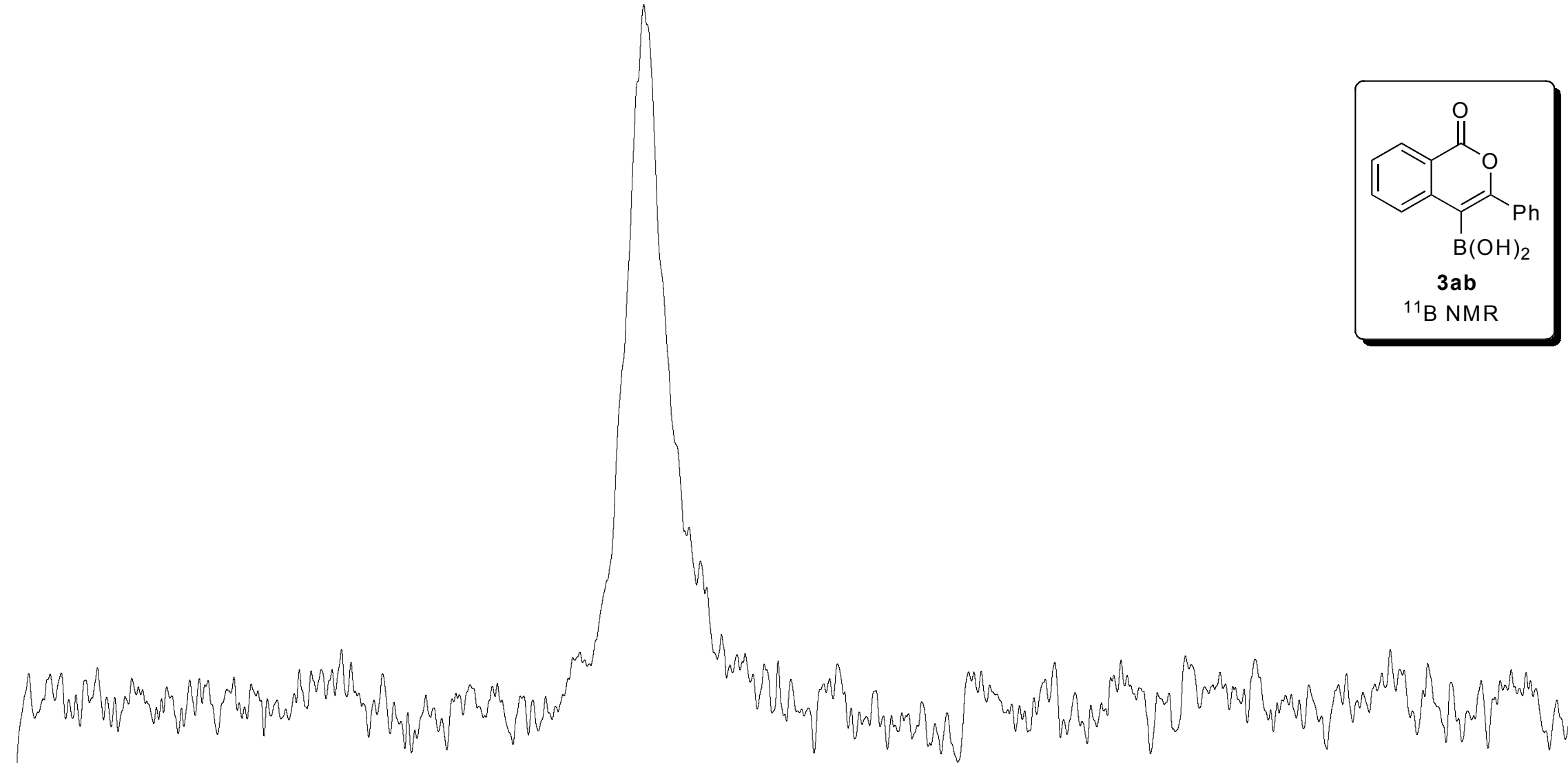

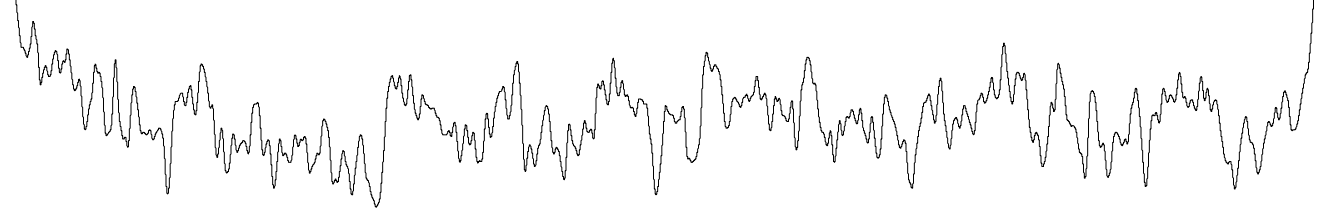



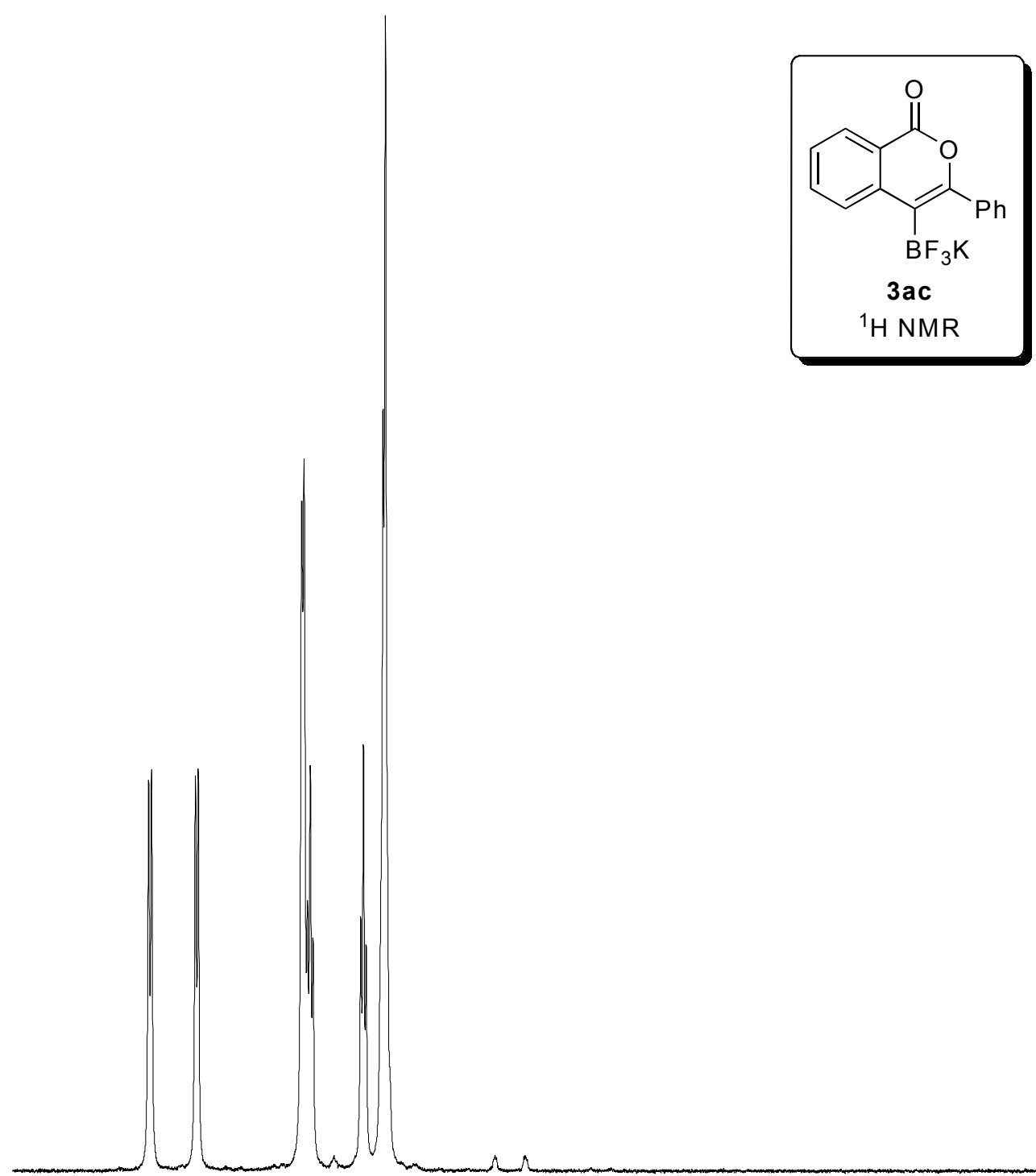

8.5 |ำ: 6.5 6.0 5.0 4.5 3.5 3.0 2.5 2.0 


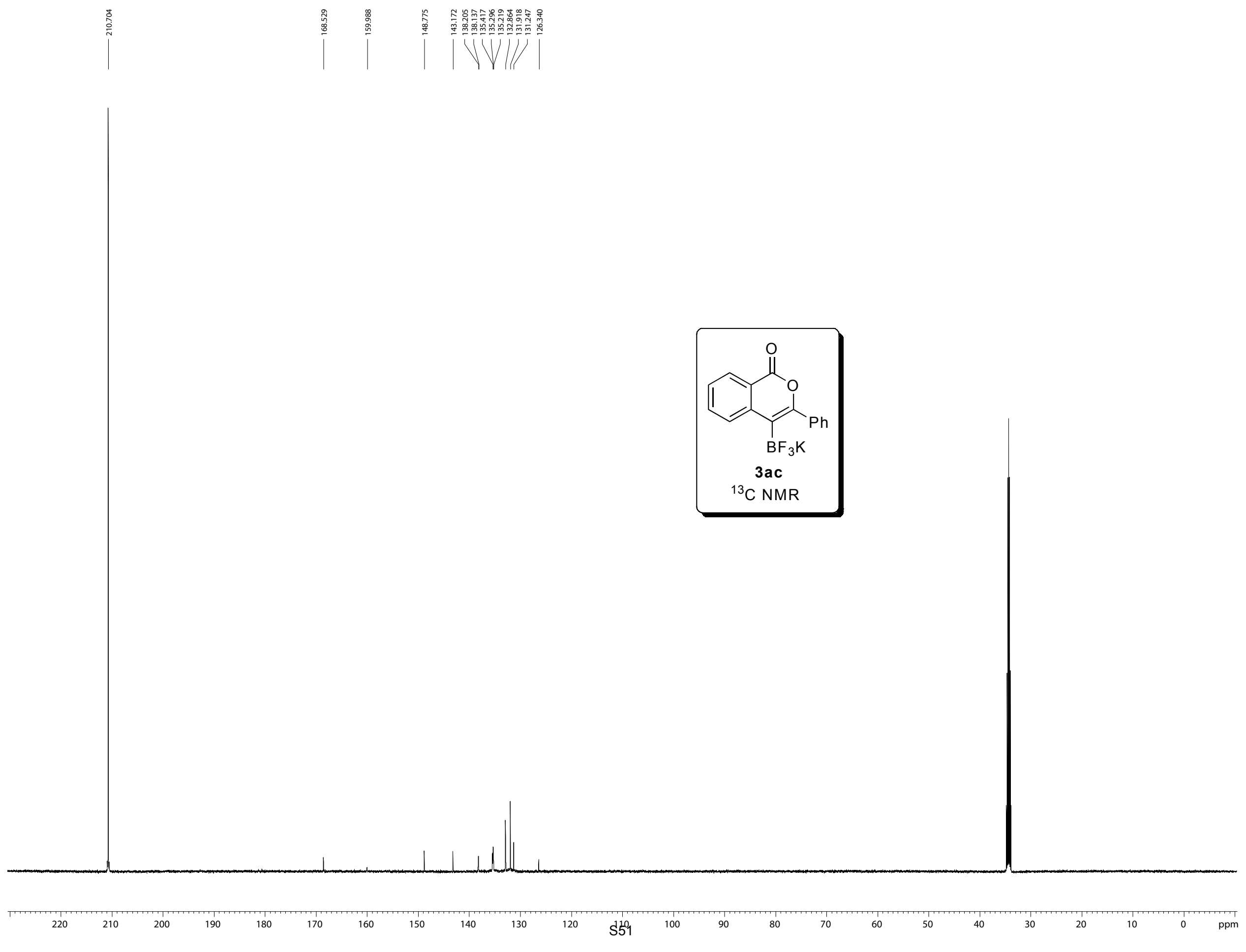




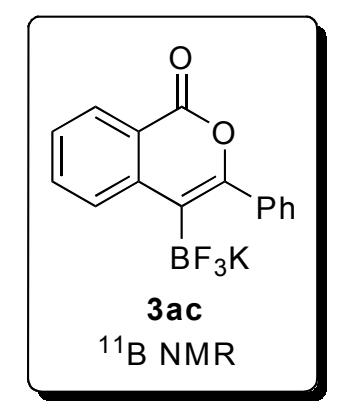




图




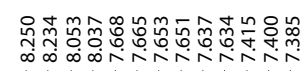

V WW V

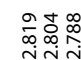

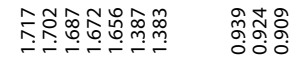

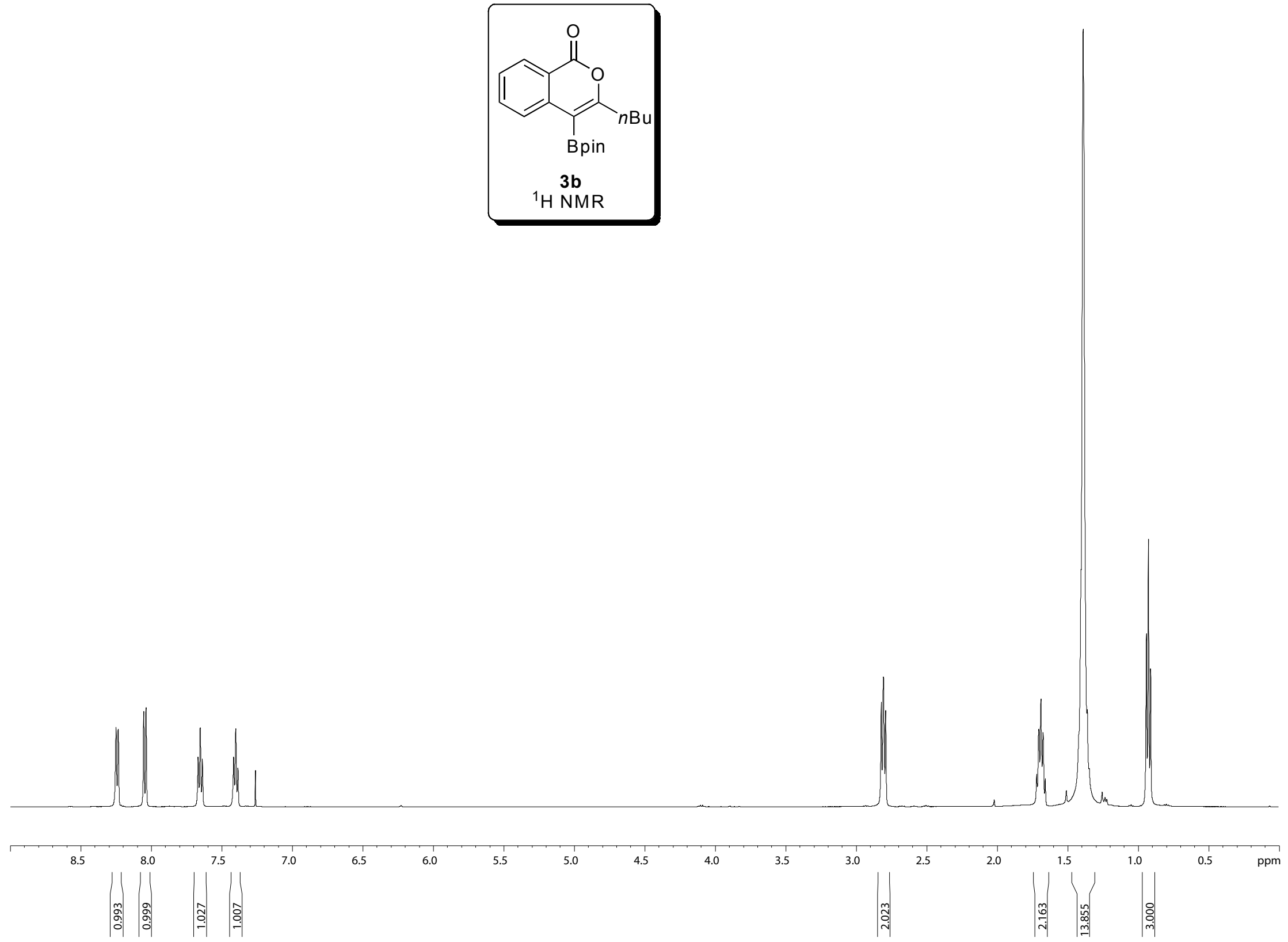

V

WV

VI 


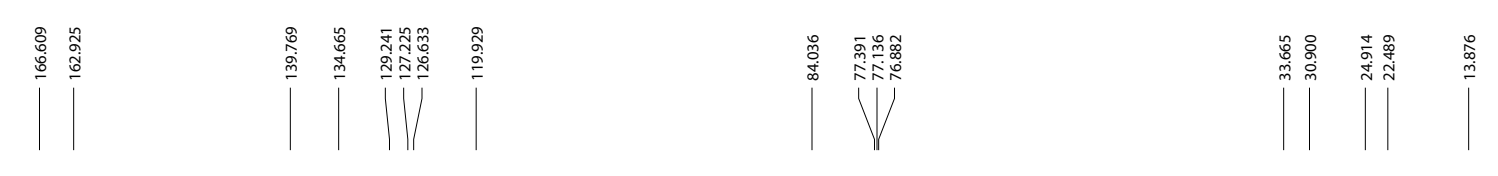
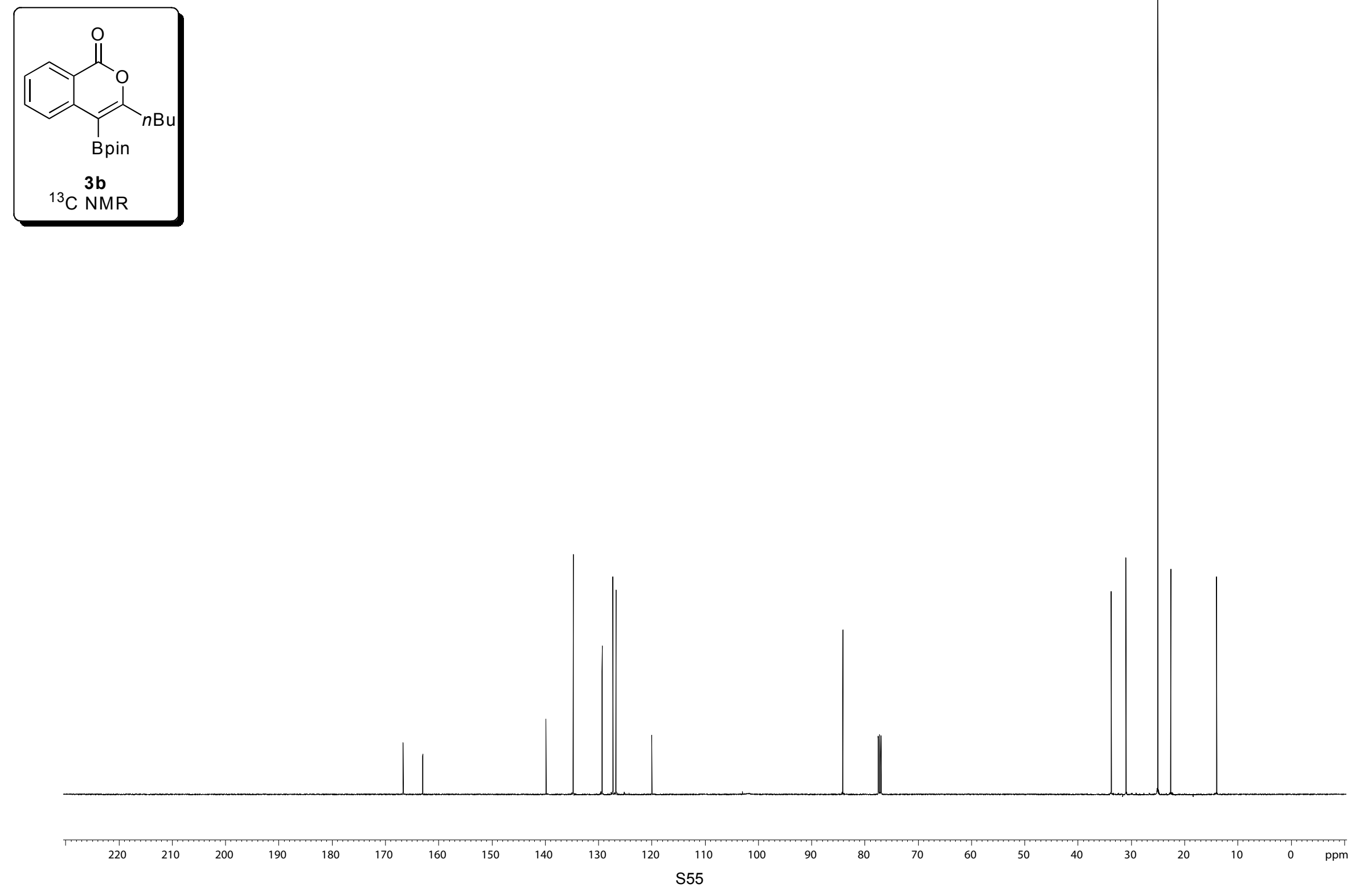


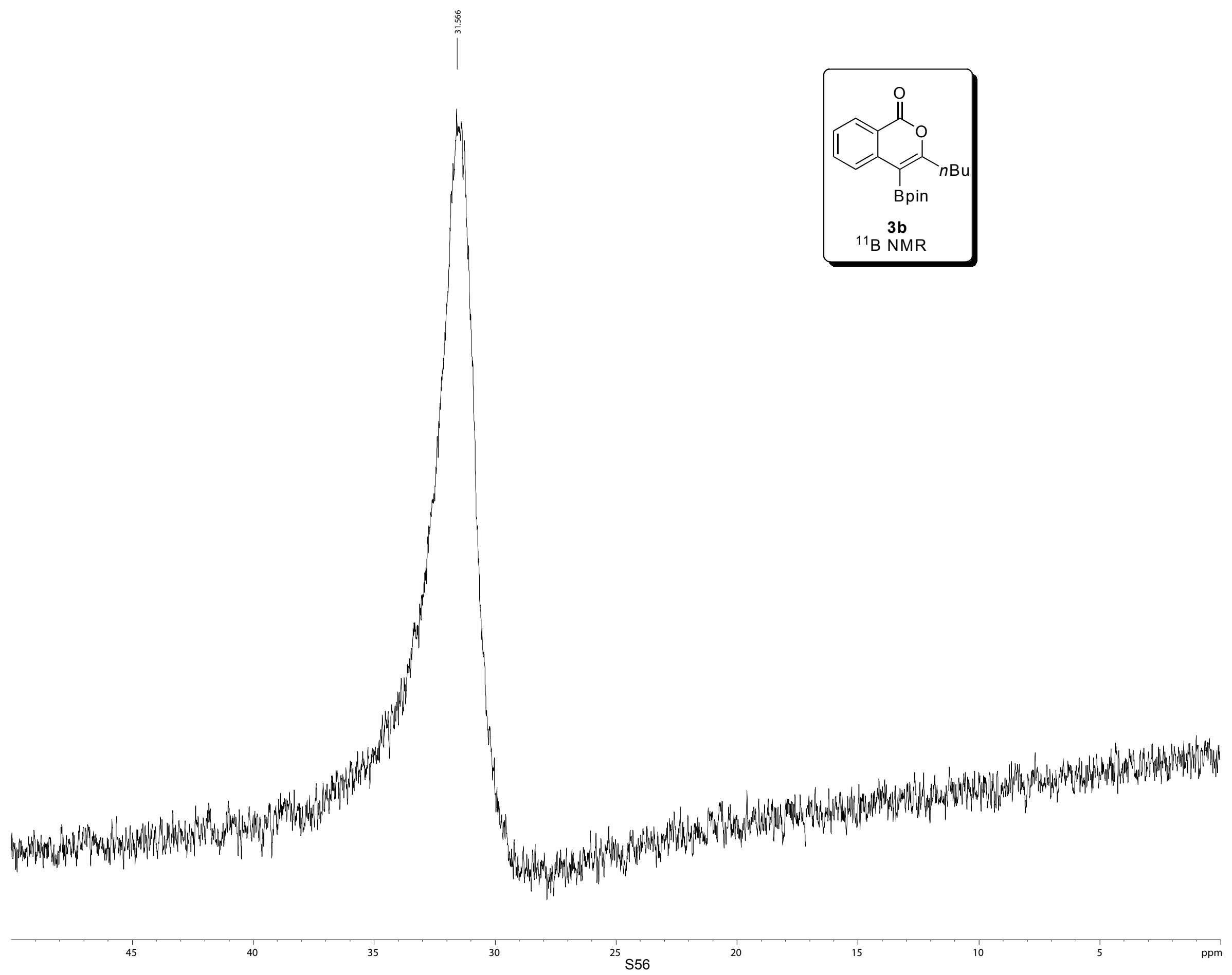




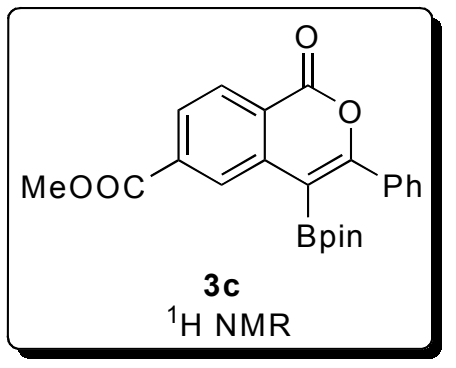

${ }^{1} \mathrm{H}$ NMR

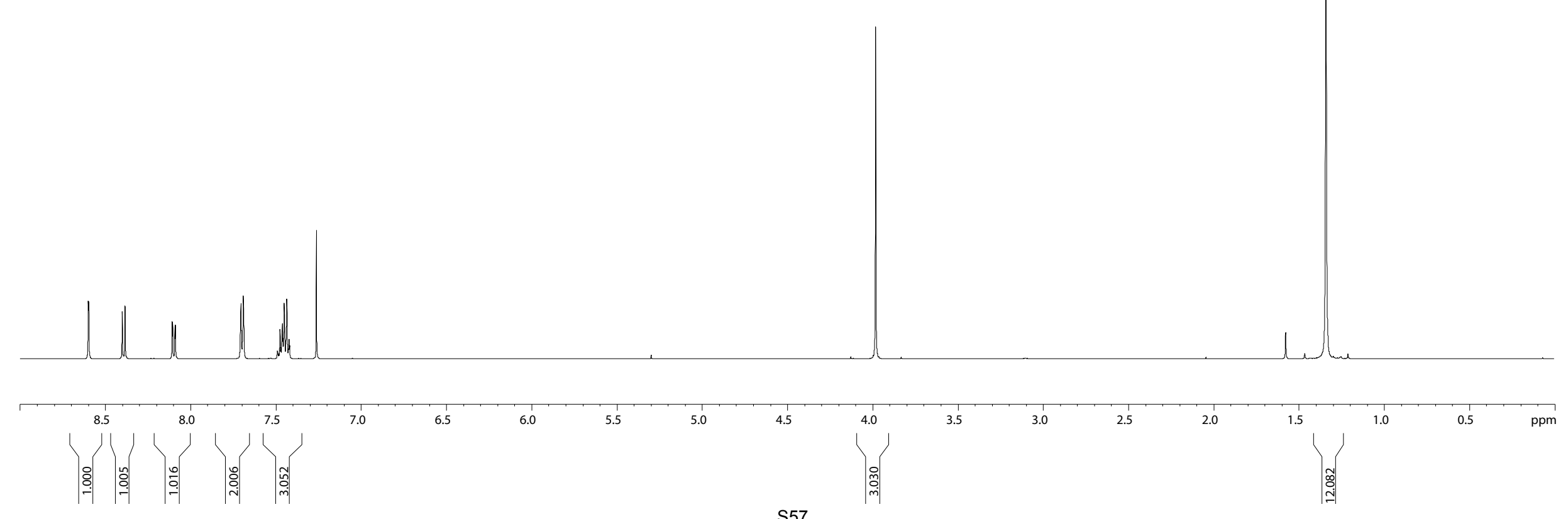



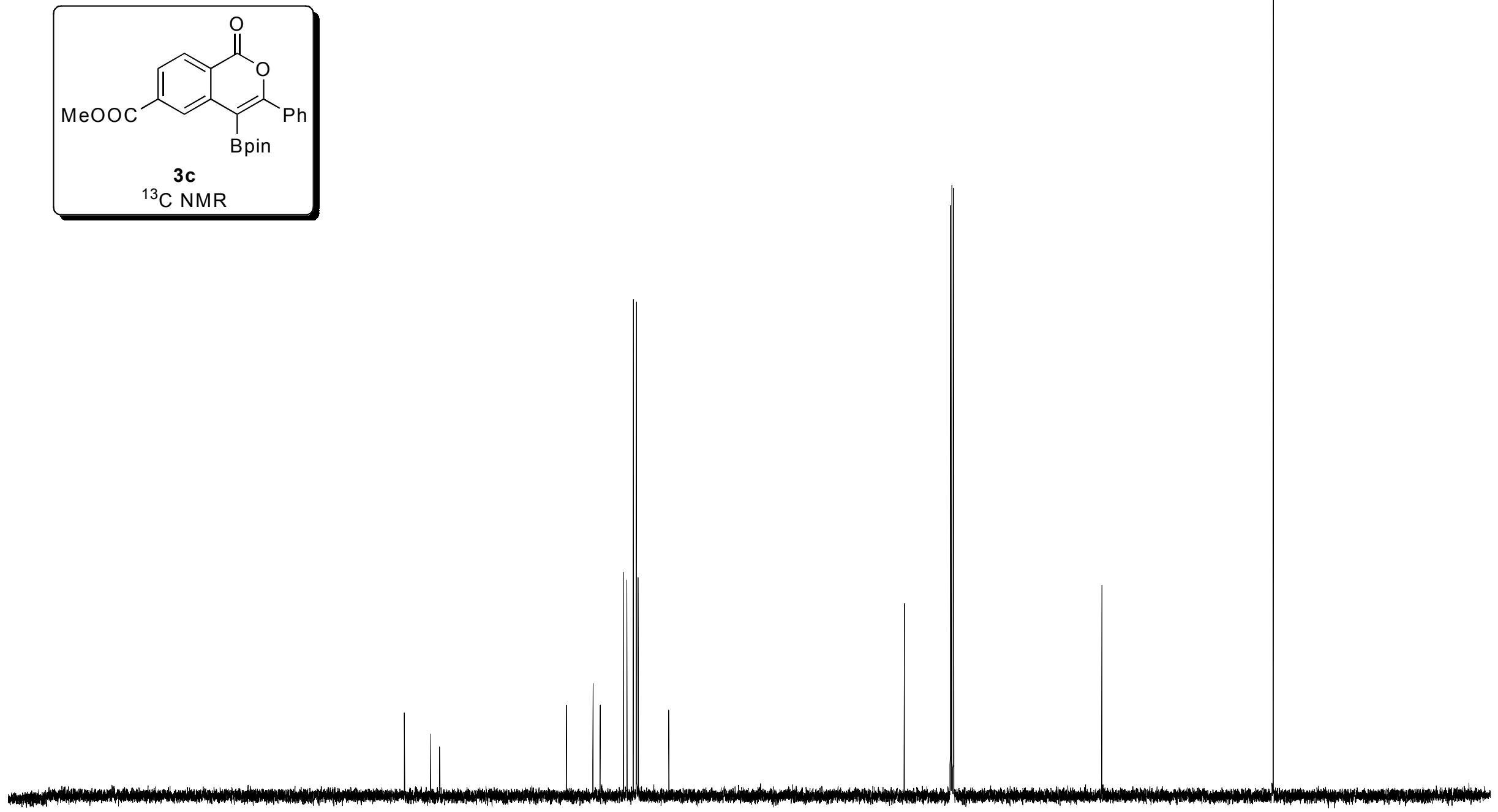

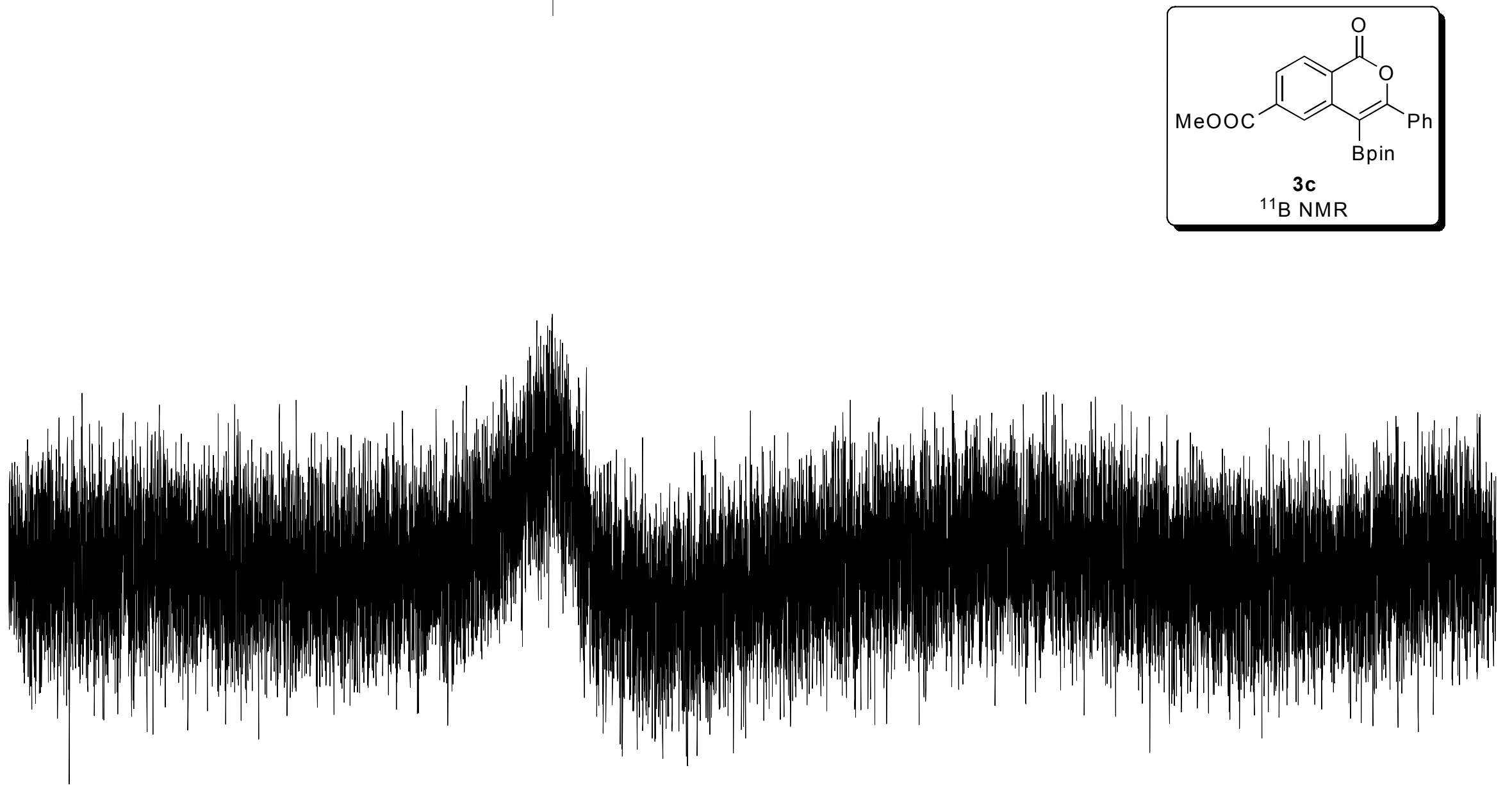


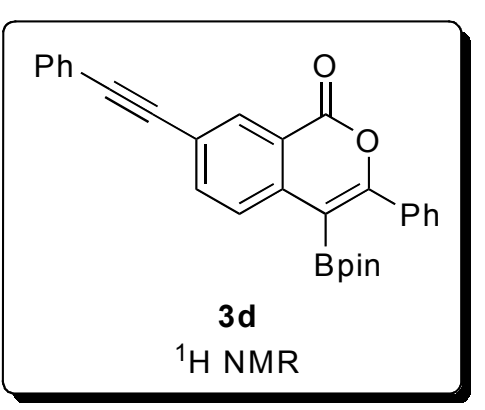

${ }^{1} \mathrm{H}$ NMR

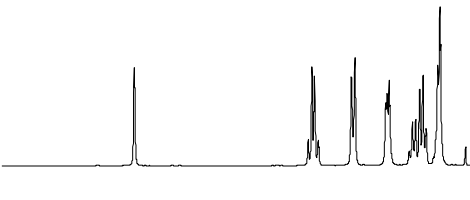

$8.5 \quad 8.0$ | 6.5 6.0
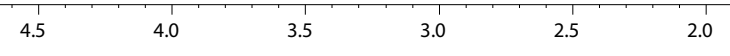
1.5

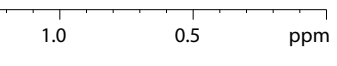



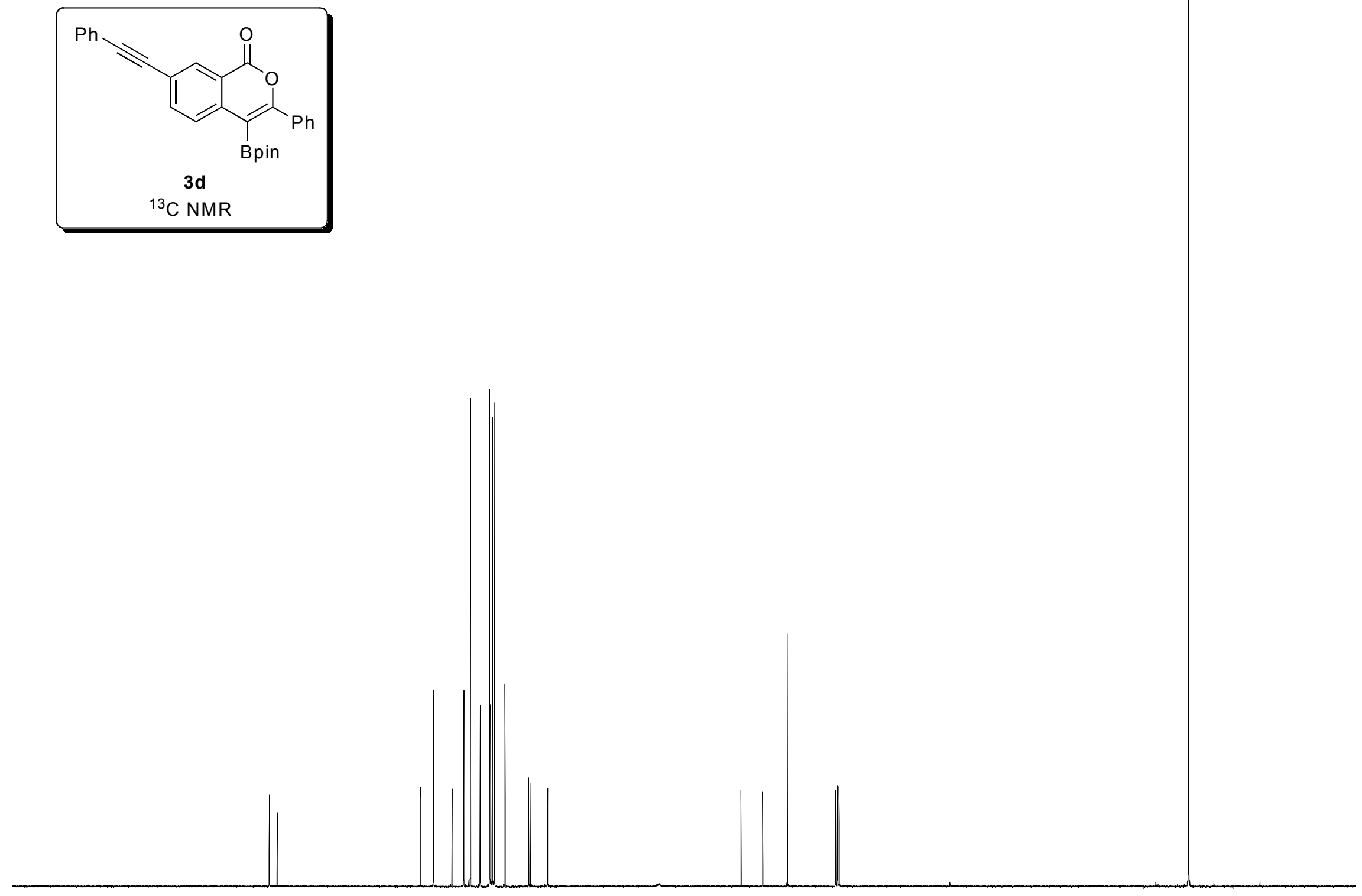

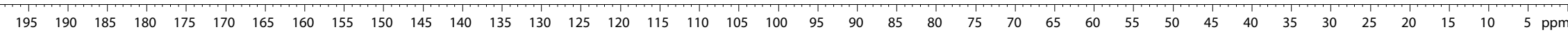



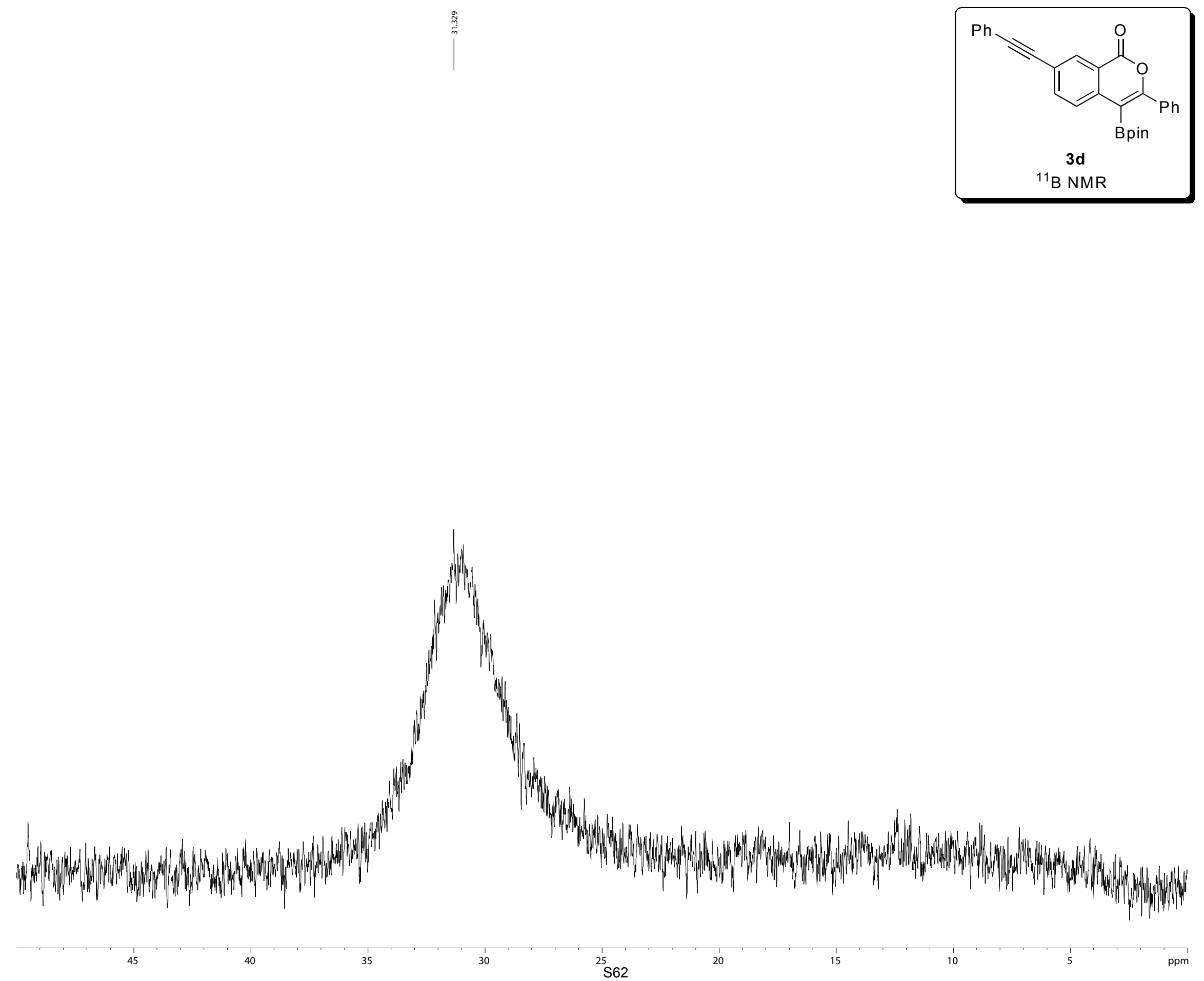


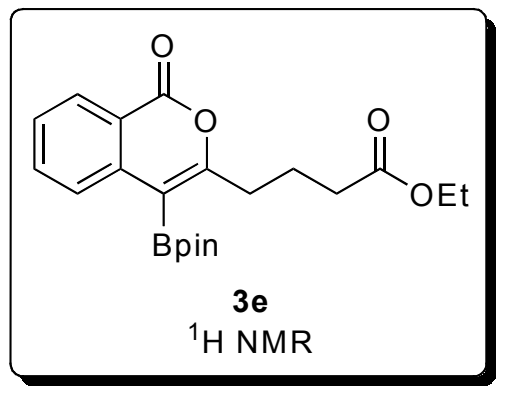

U山 

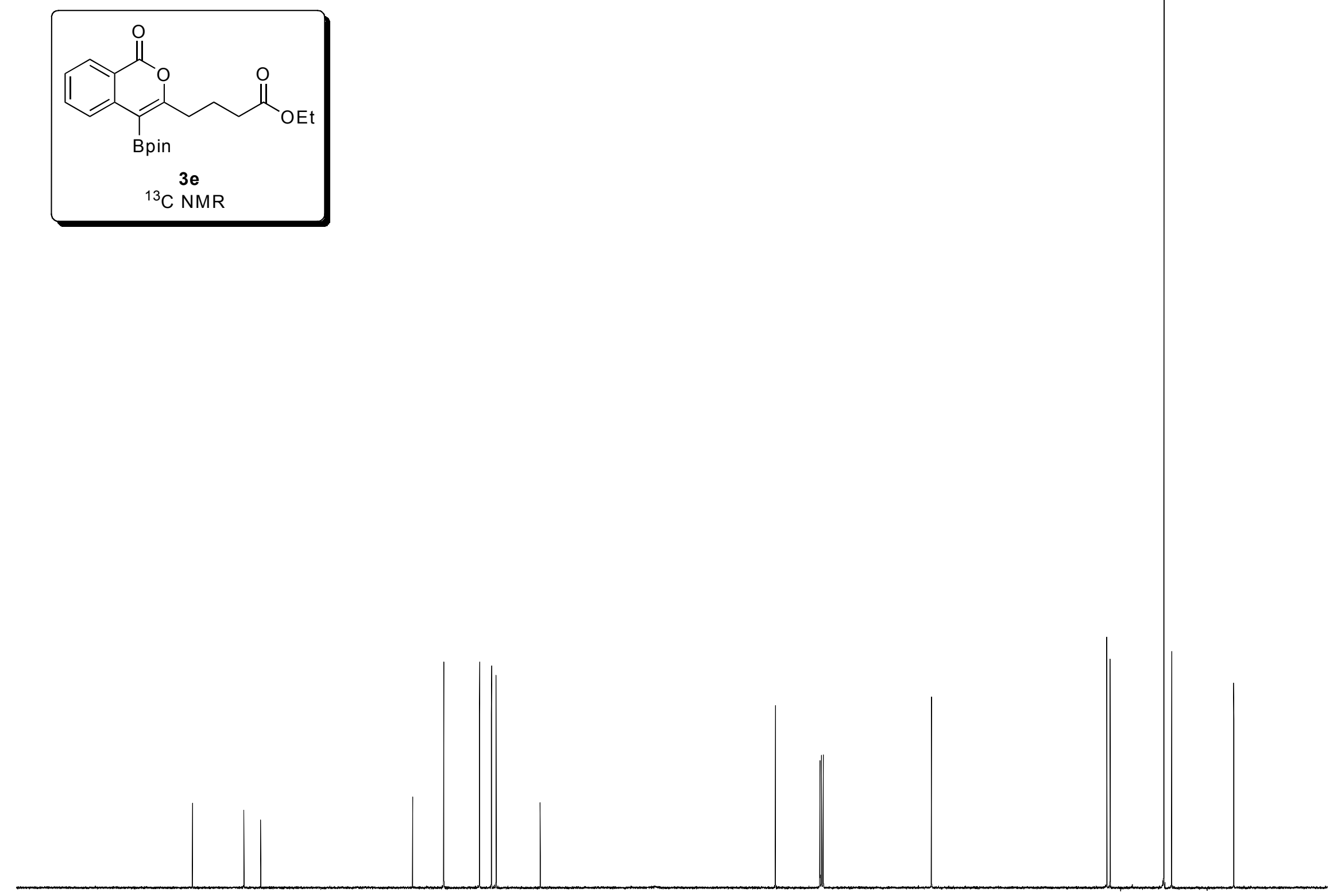

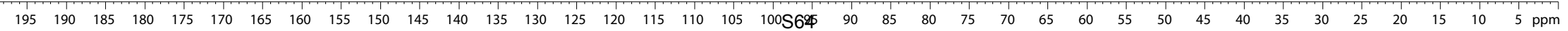



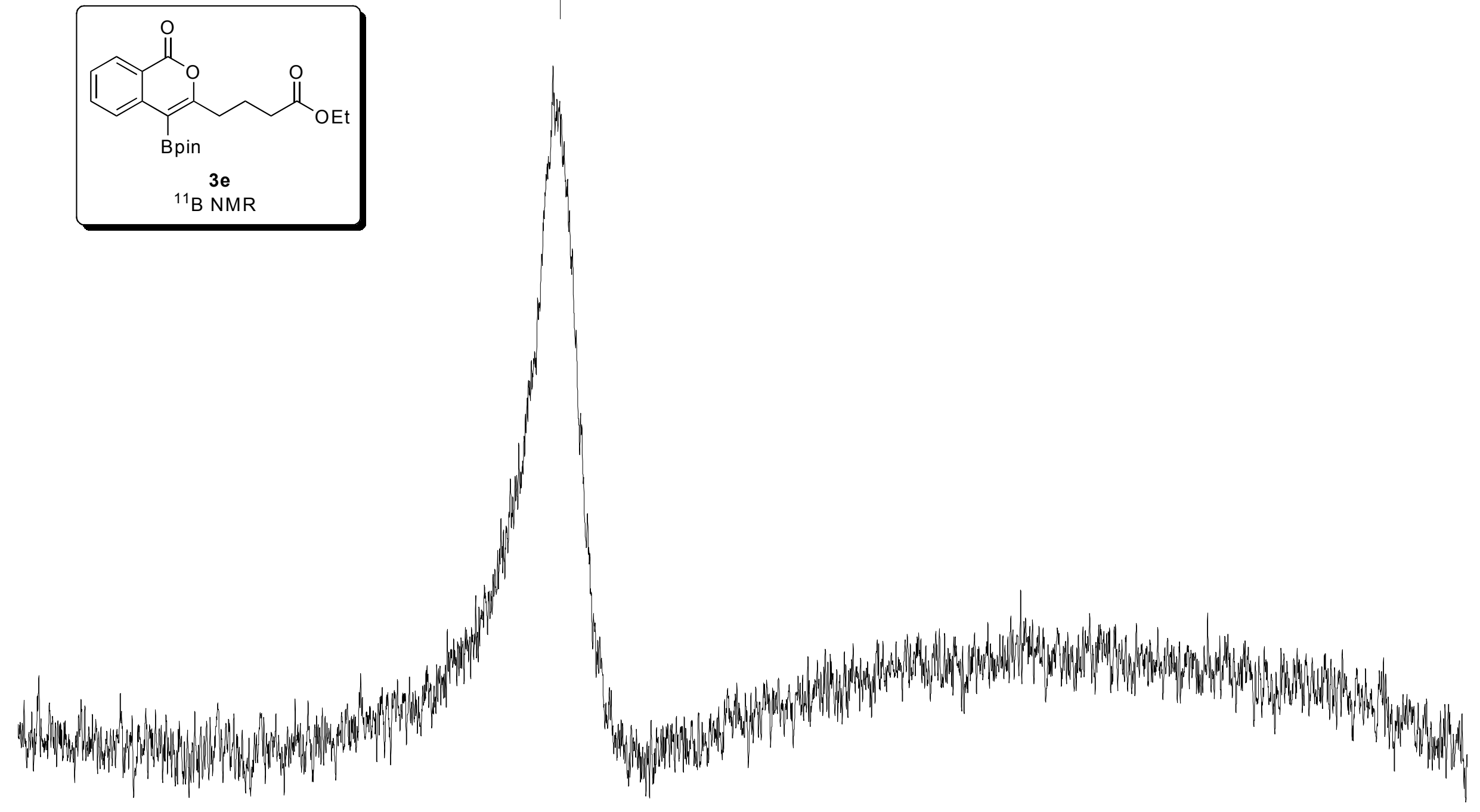
$\left.\right|^{\text {on }}$

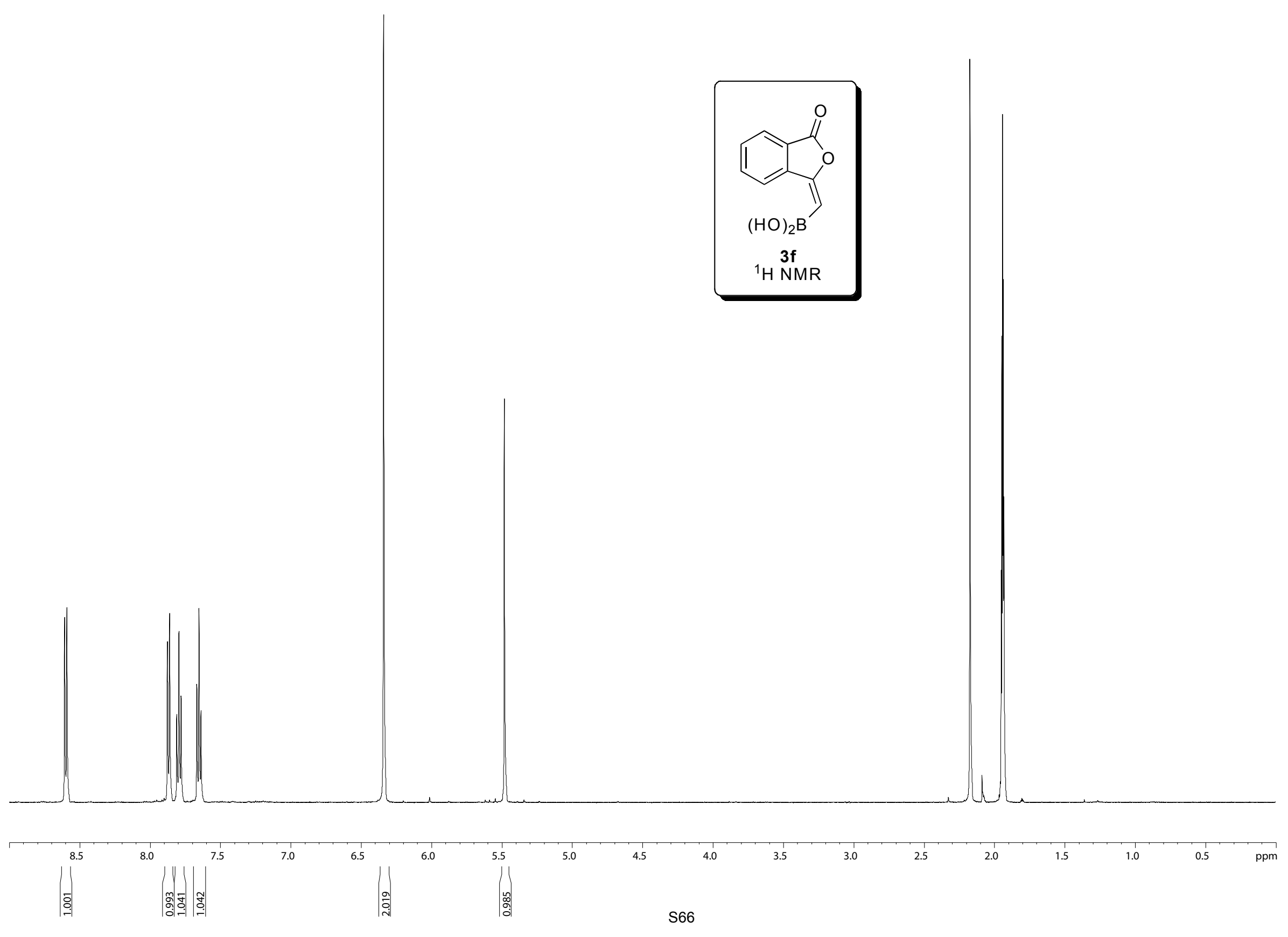




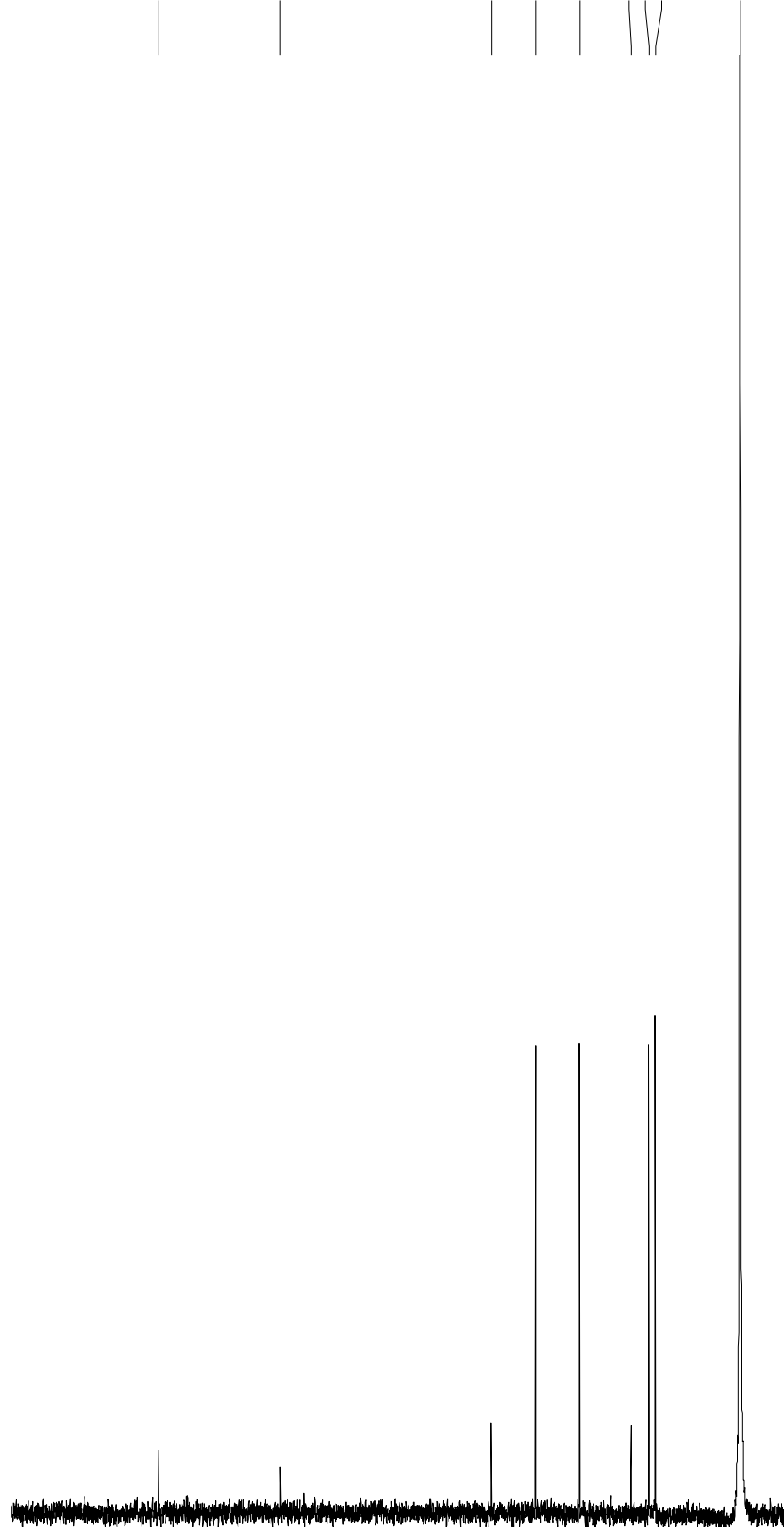



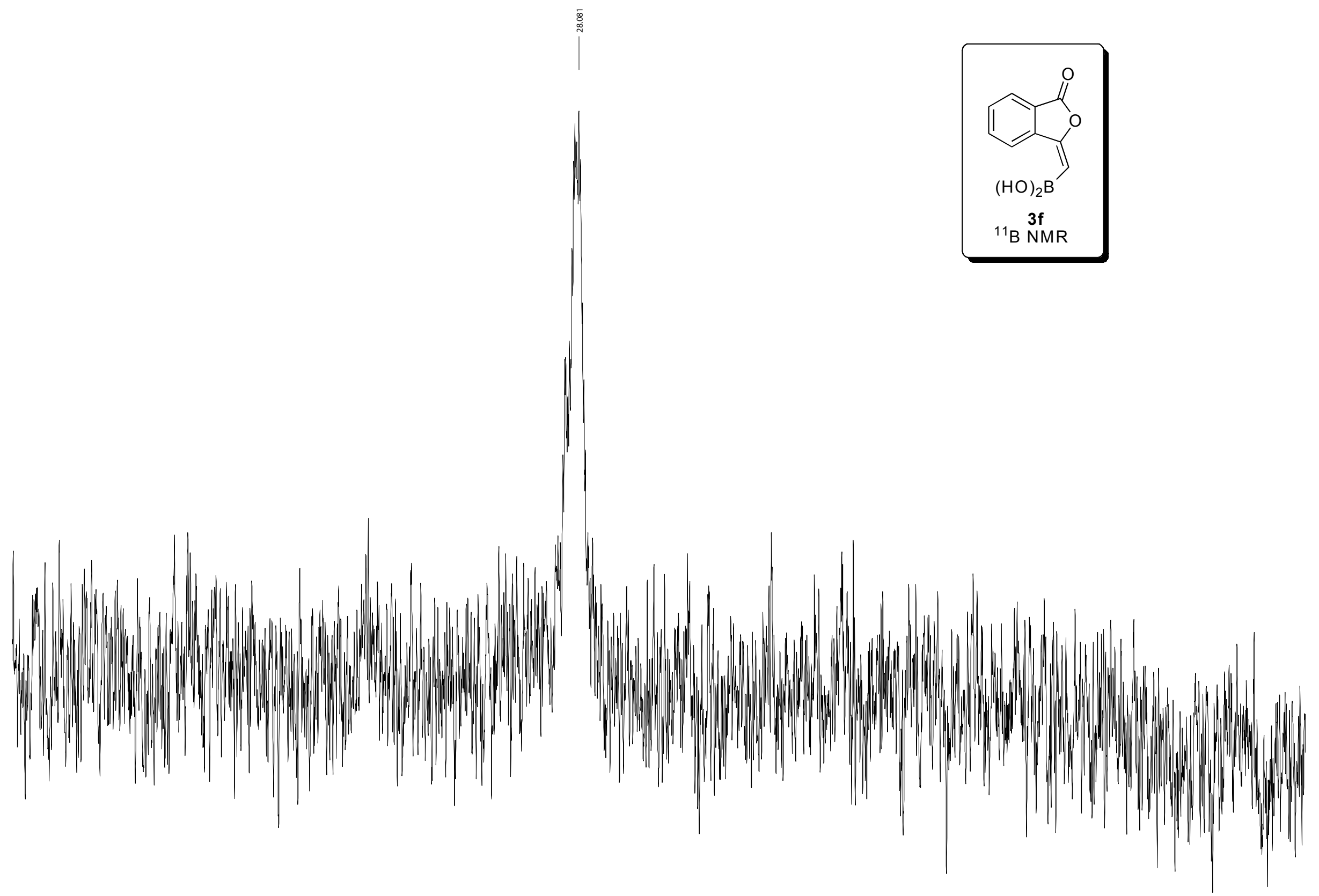


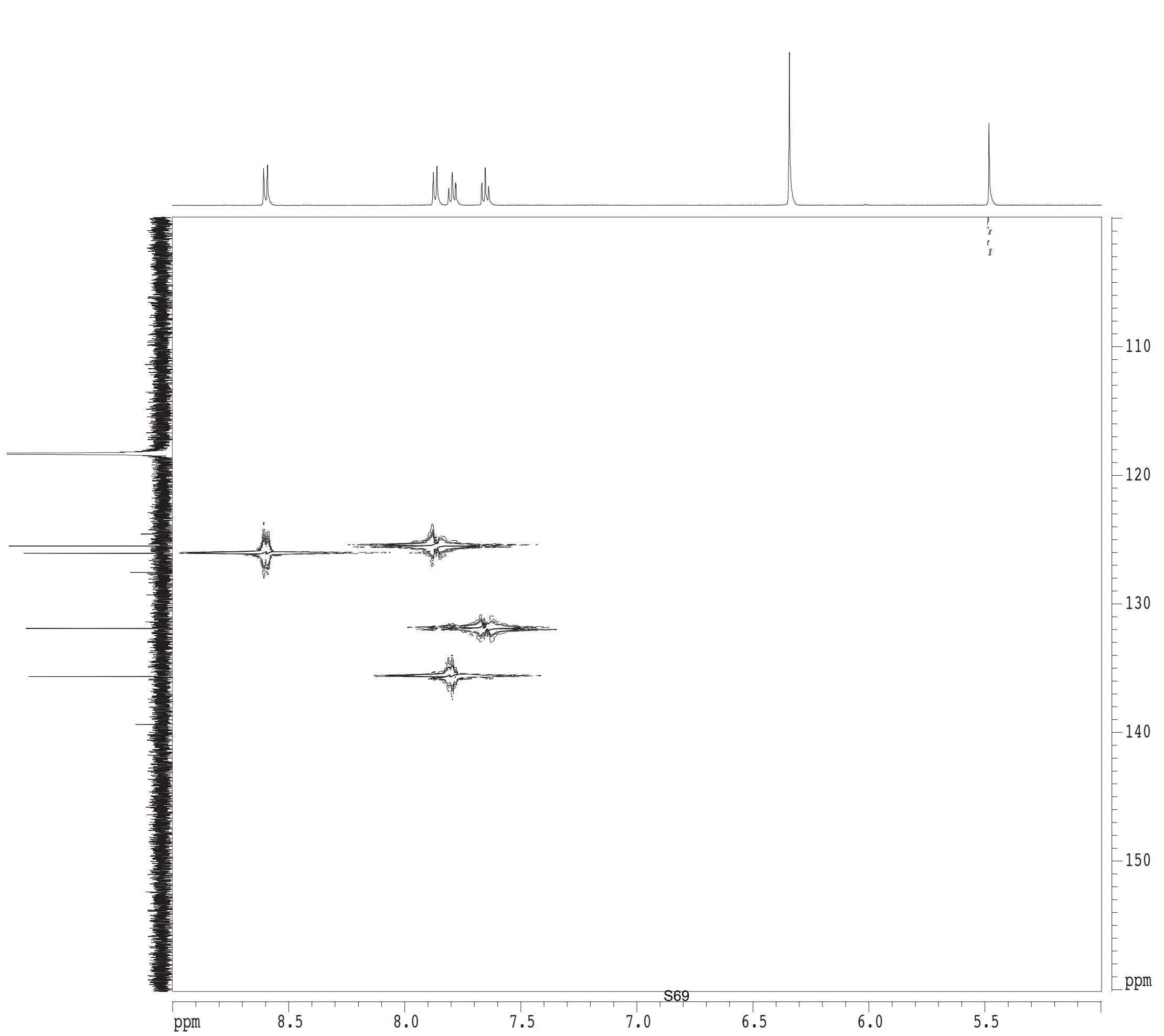




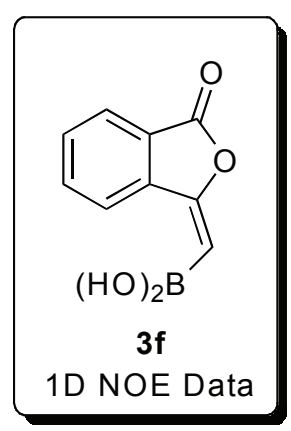



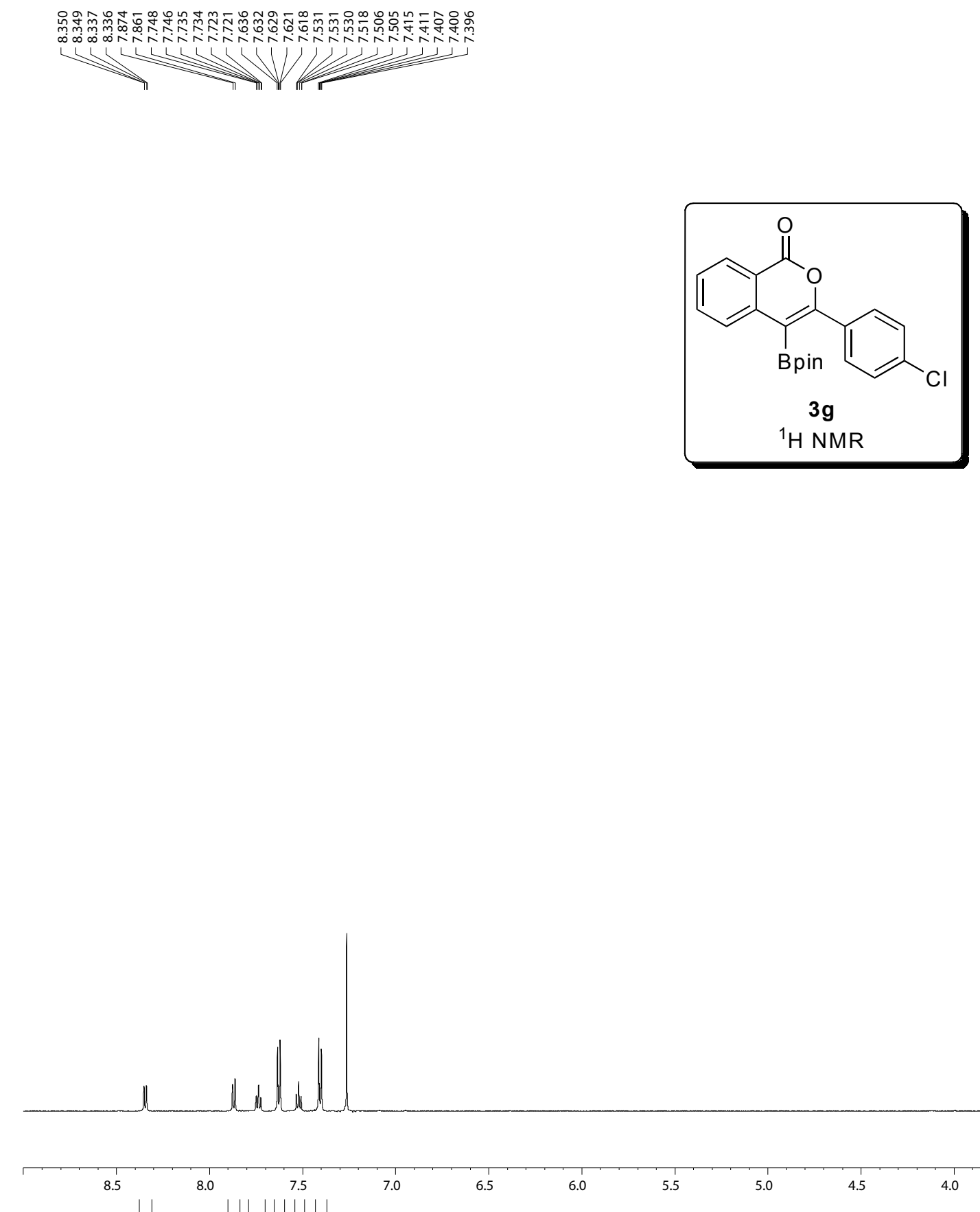

6.5
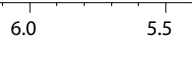

5.0

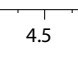

4.0
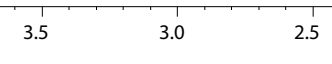

2.0 1.5 

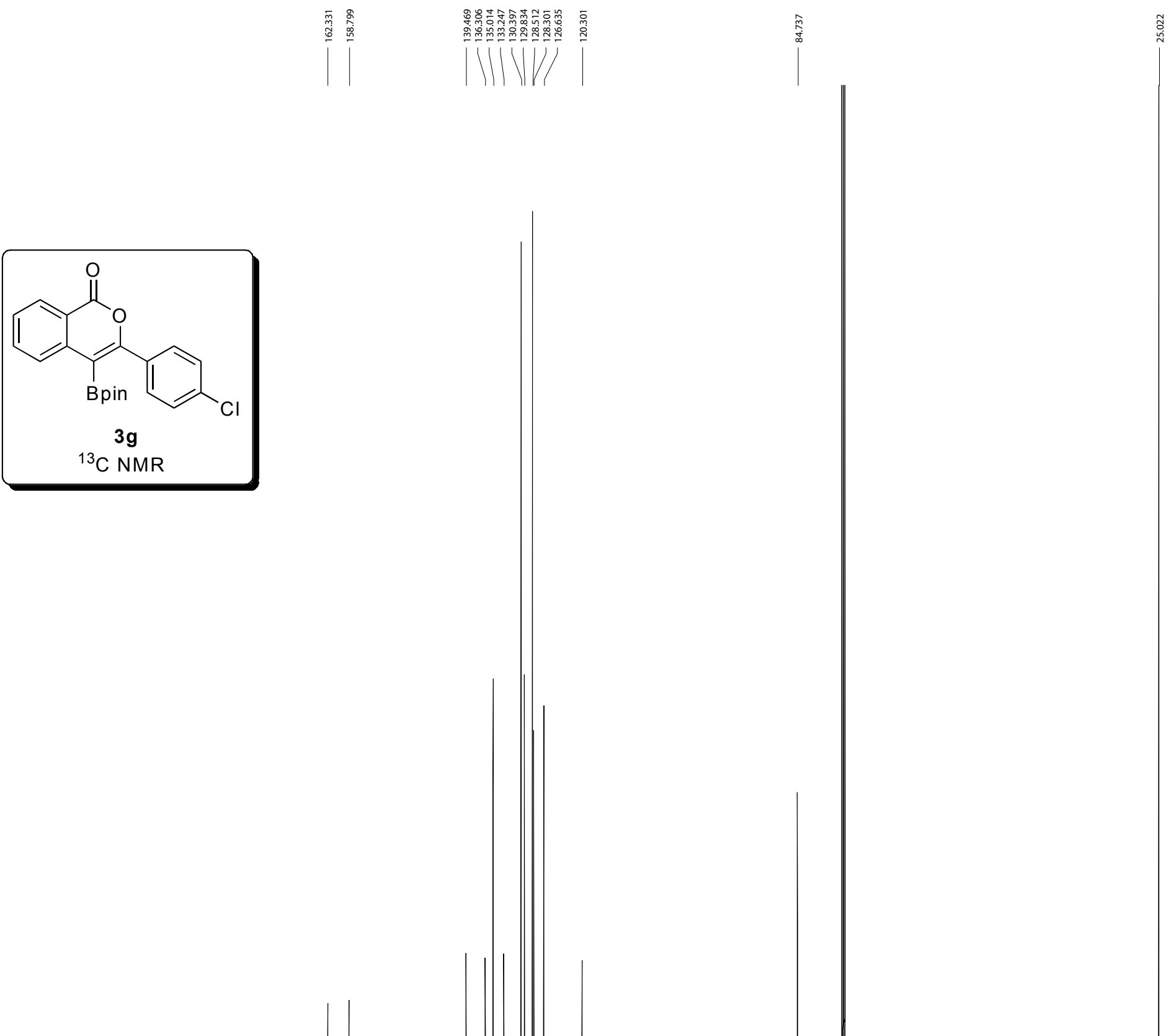

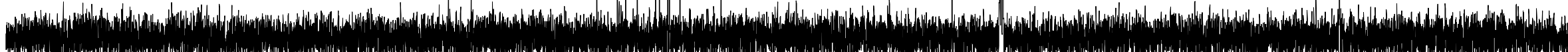

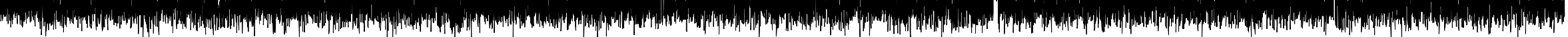



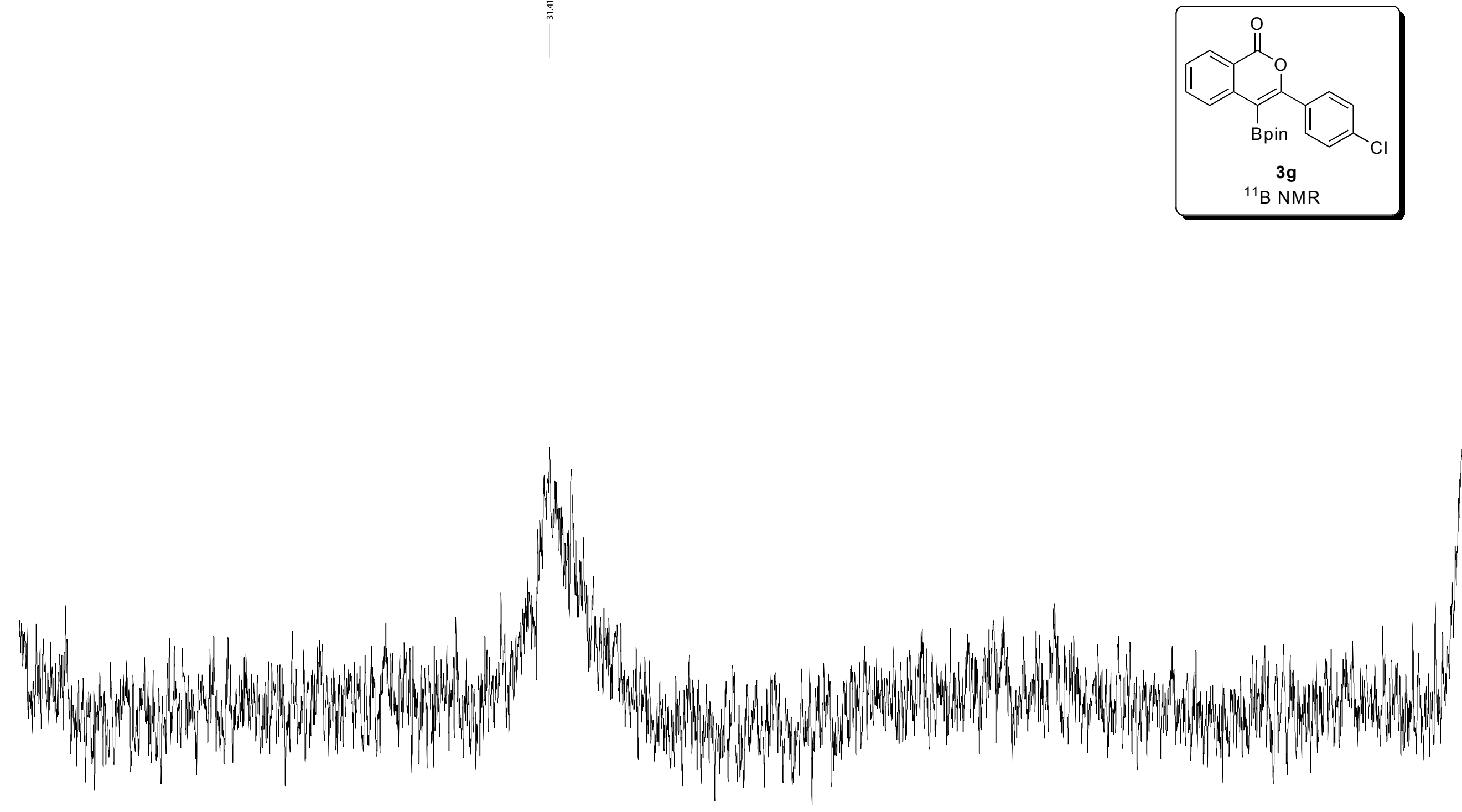

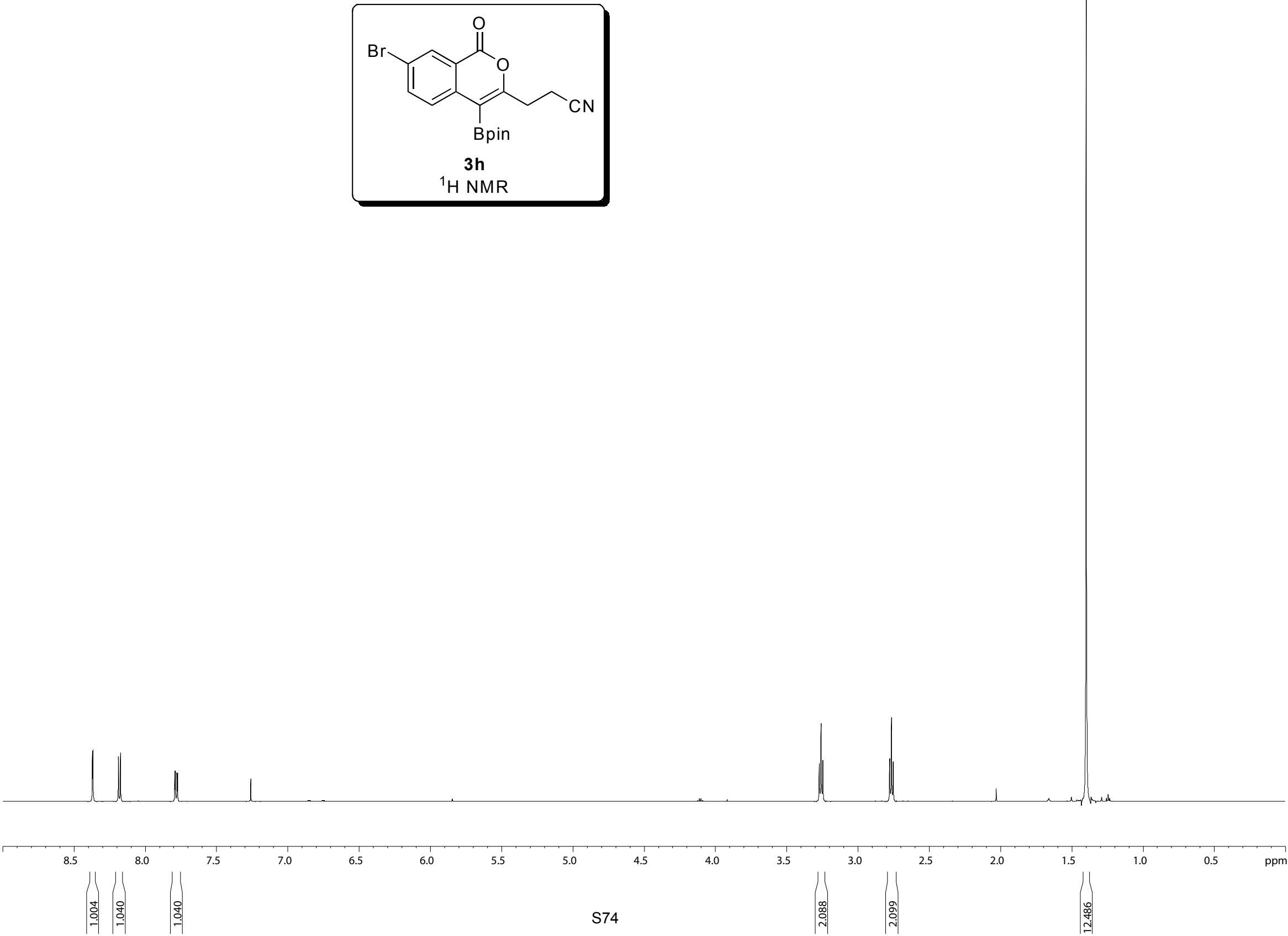


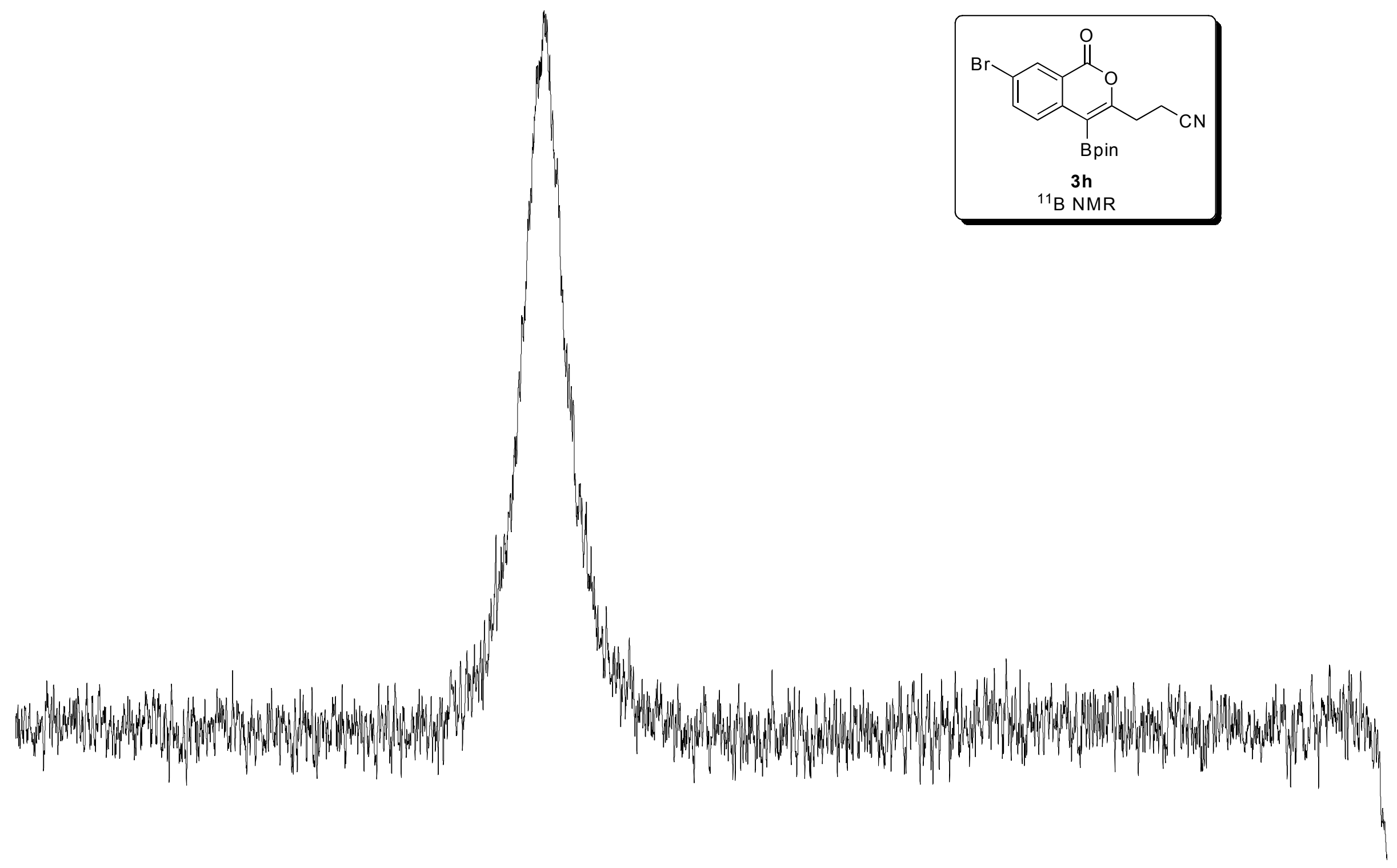



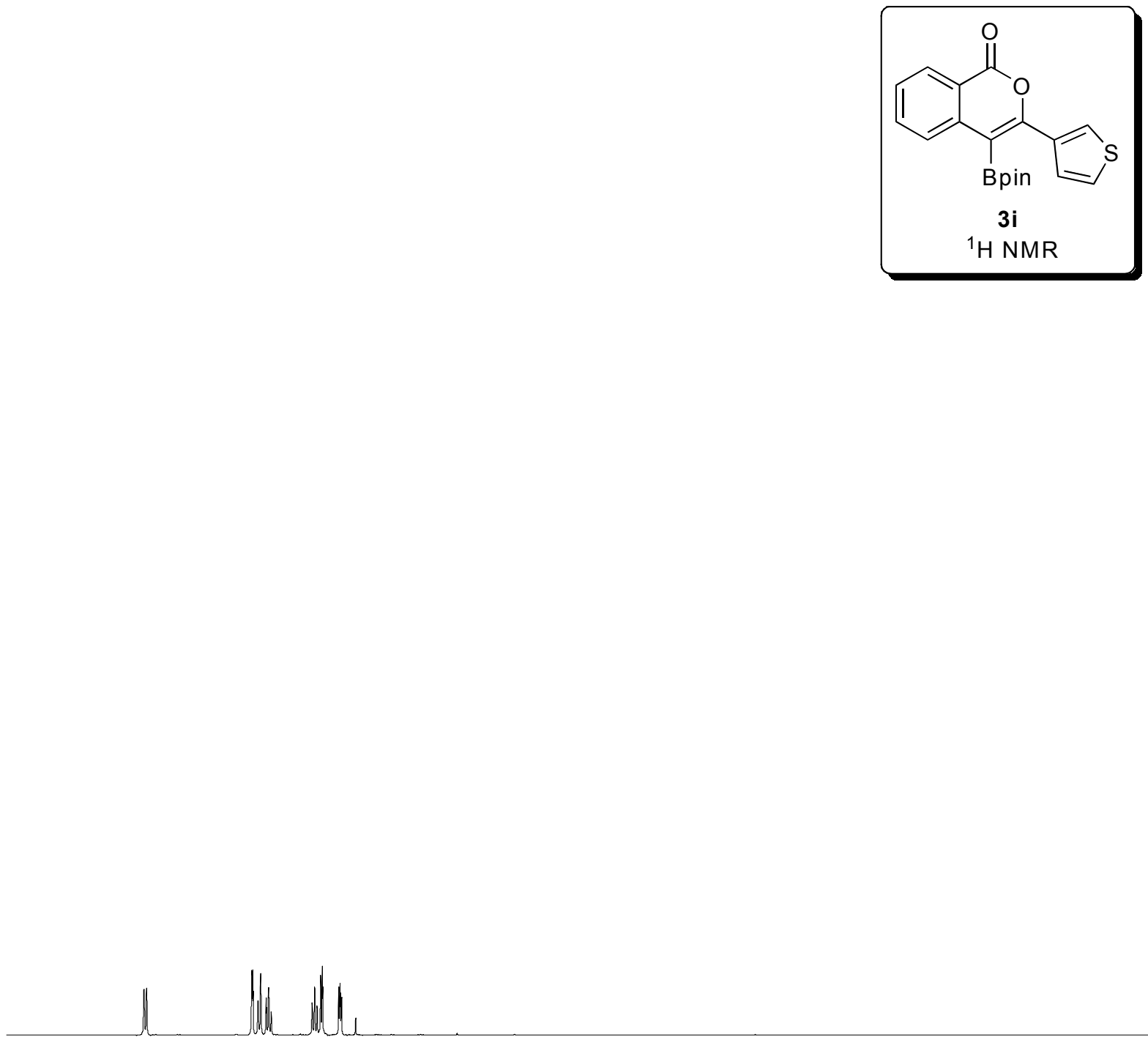
7.5 ) วิ
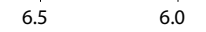

5.5

5.0

4.5 

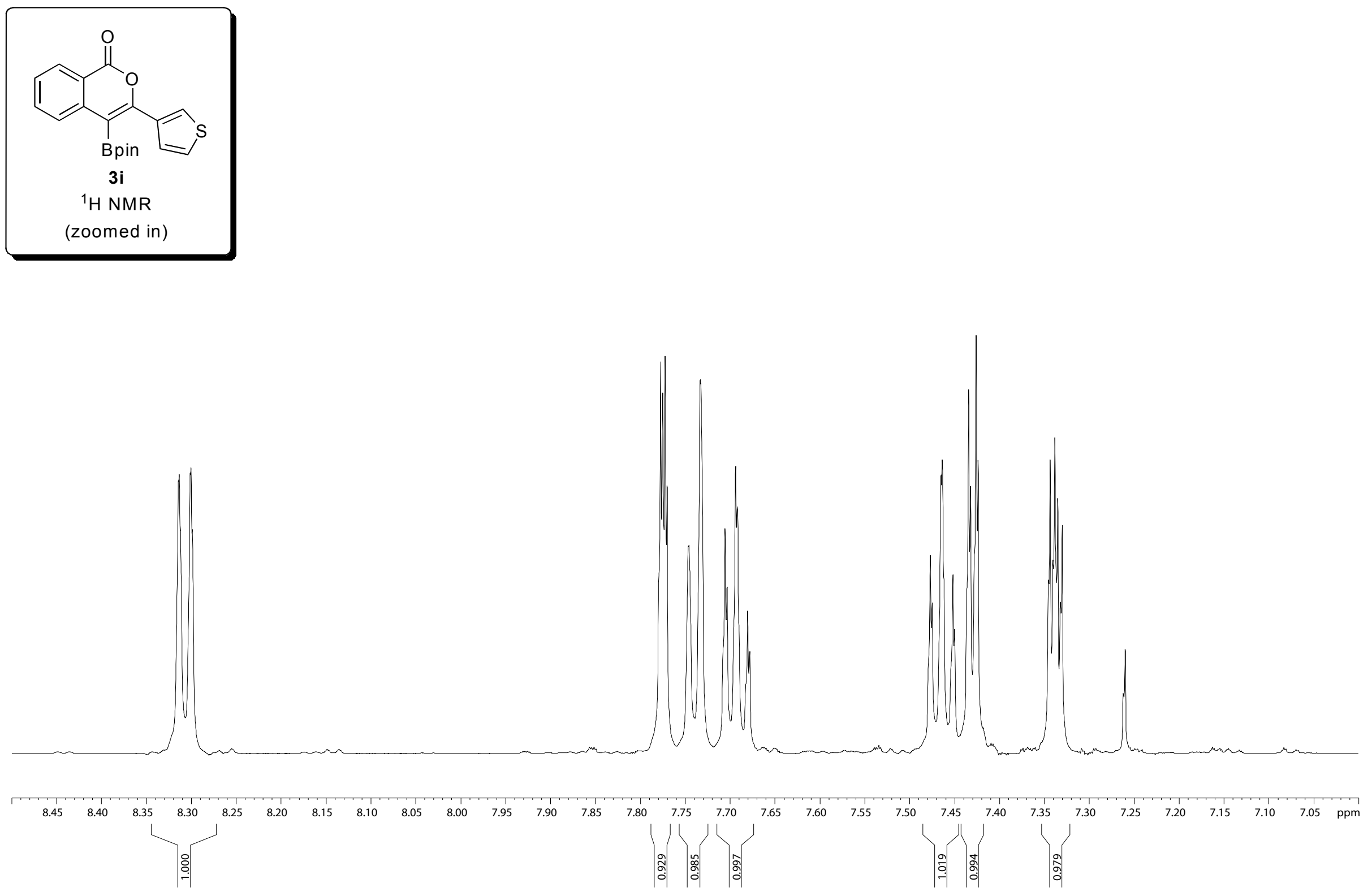

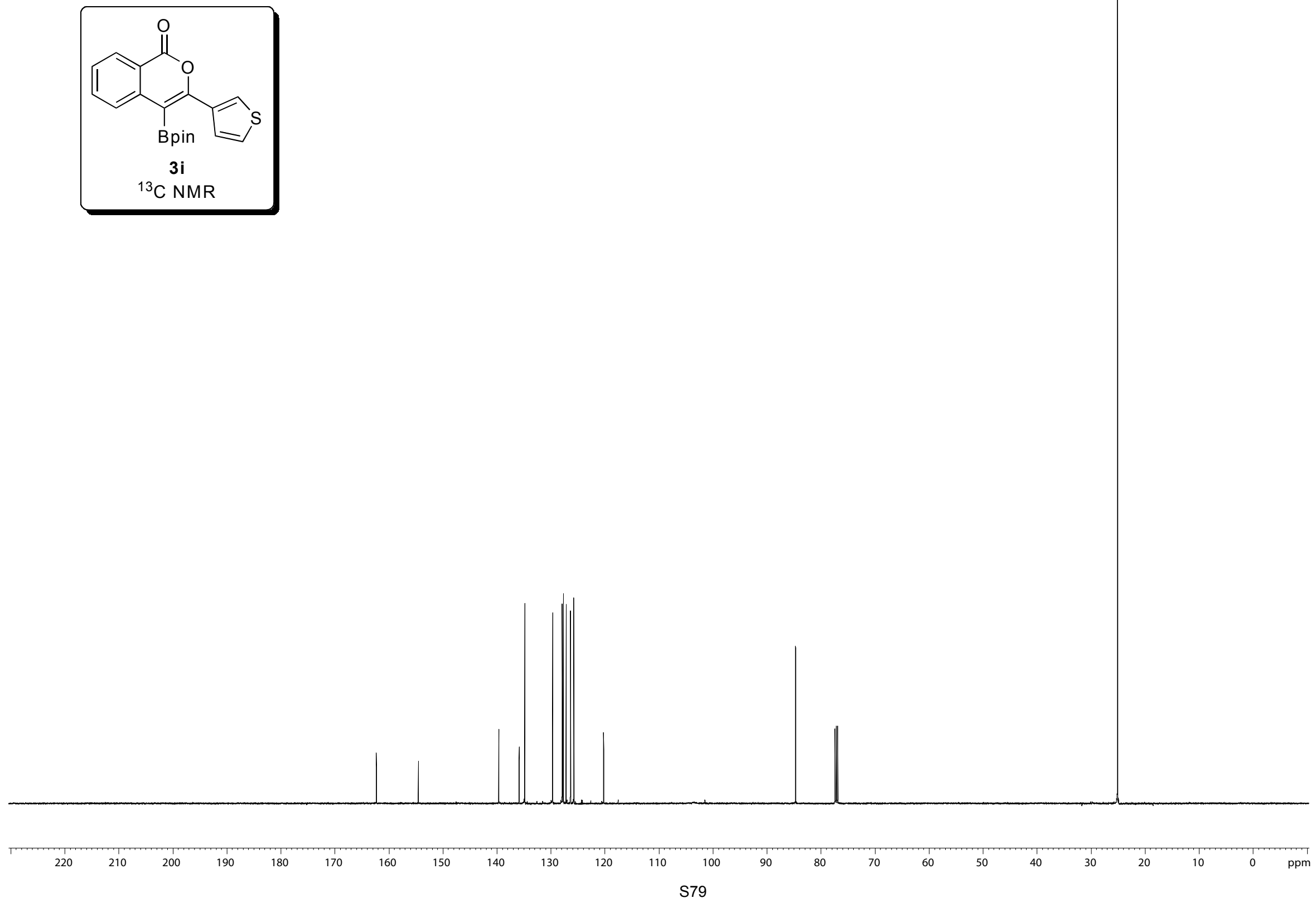


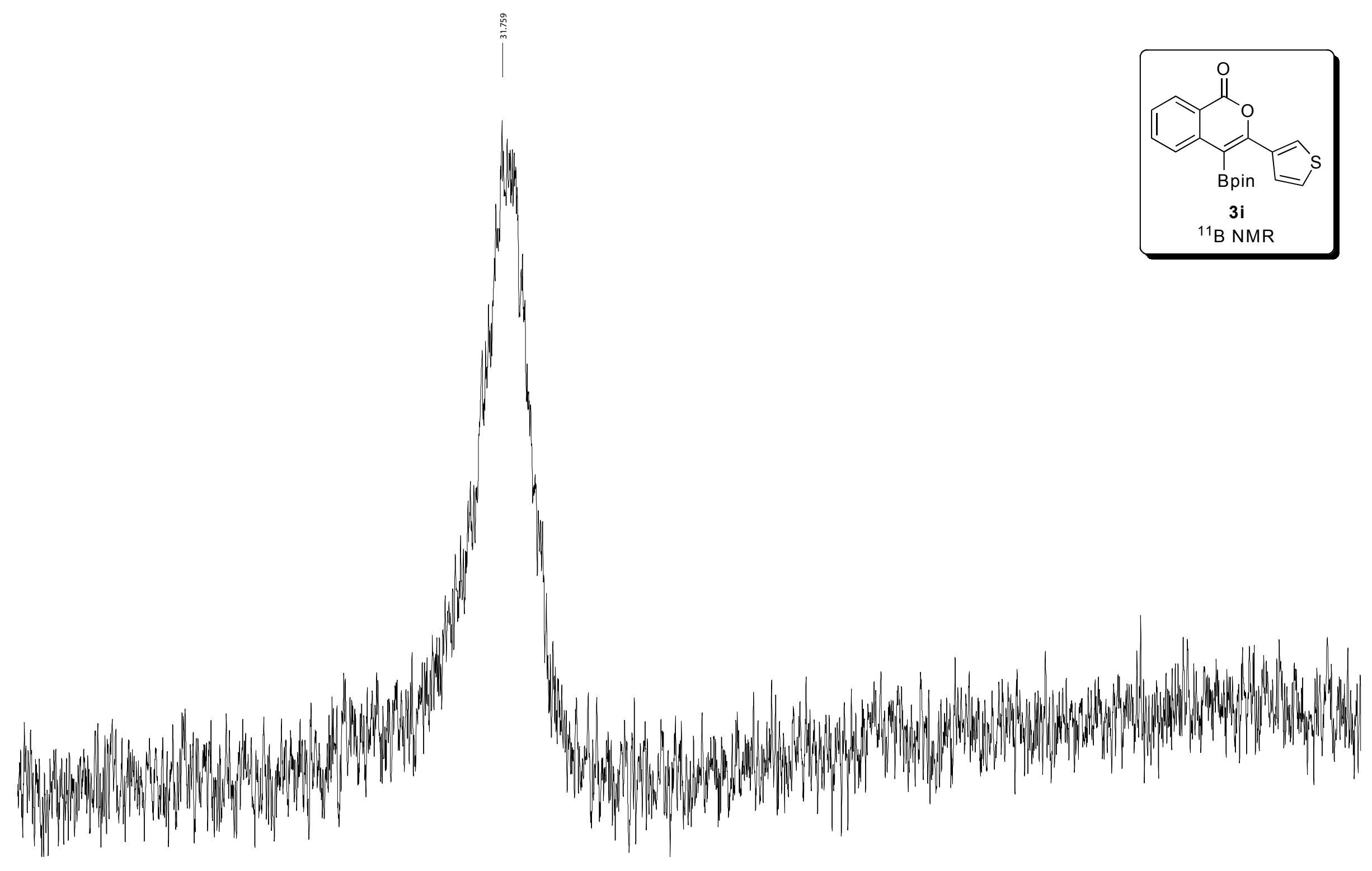



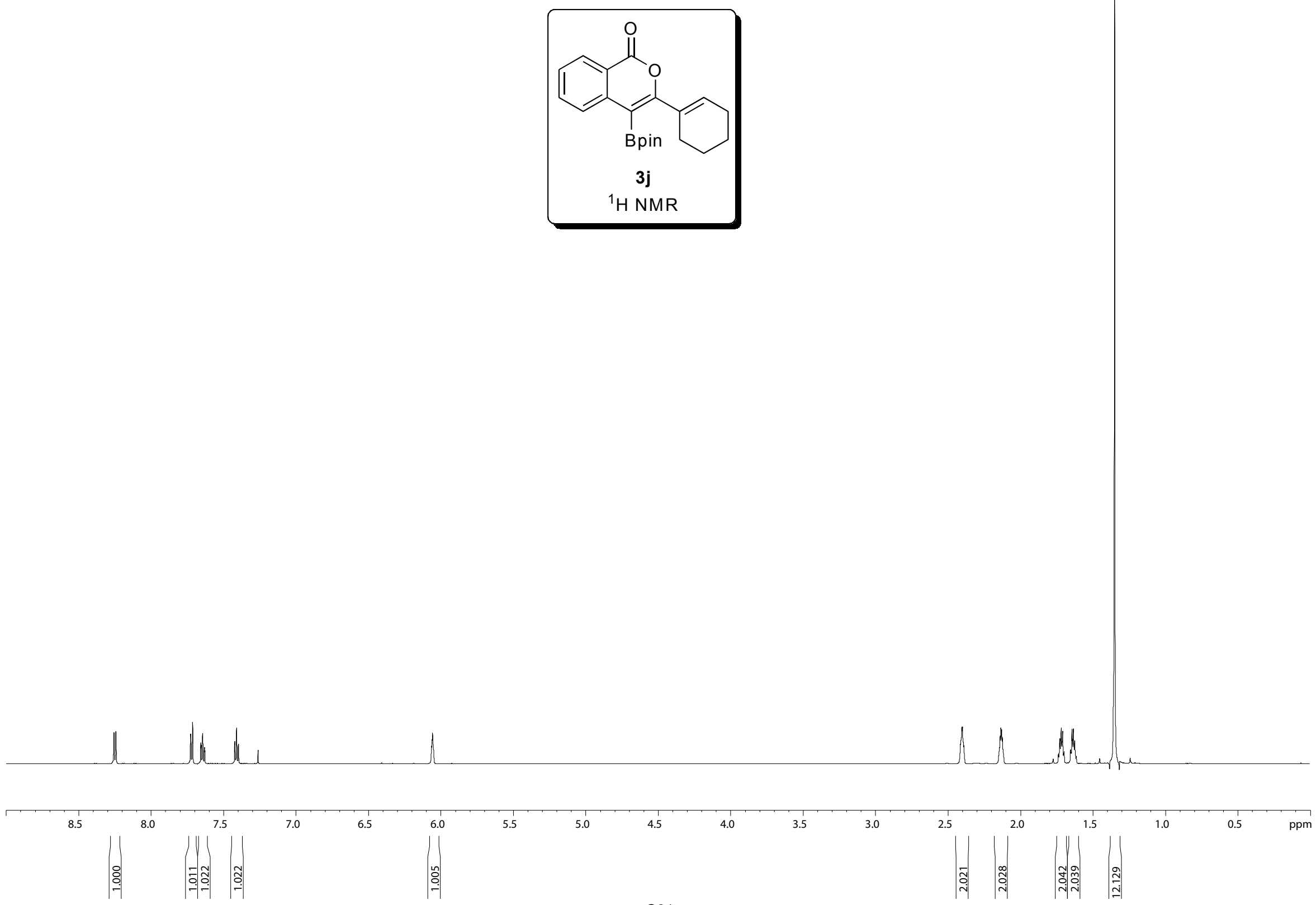

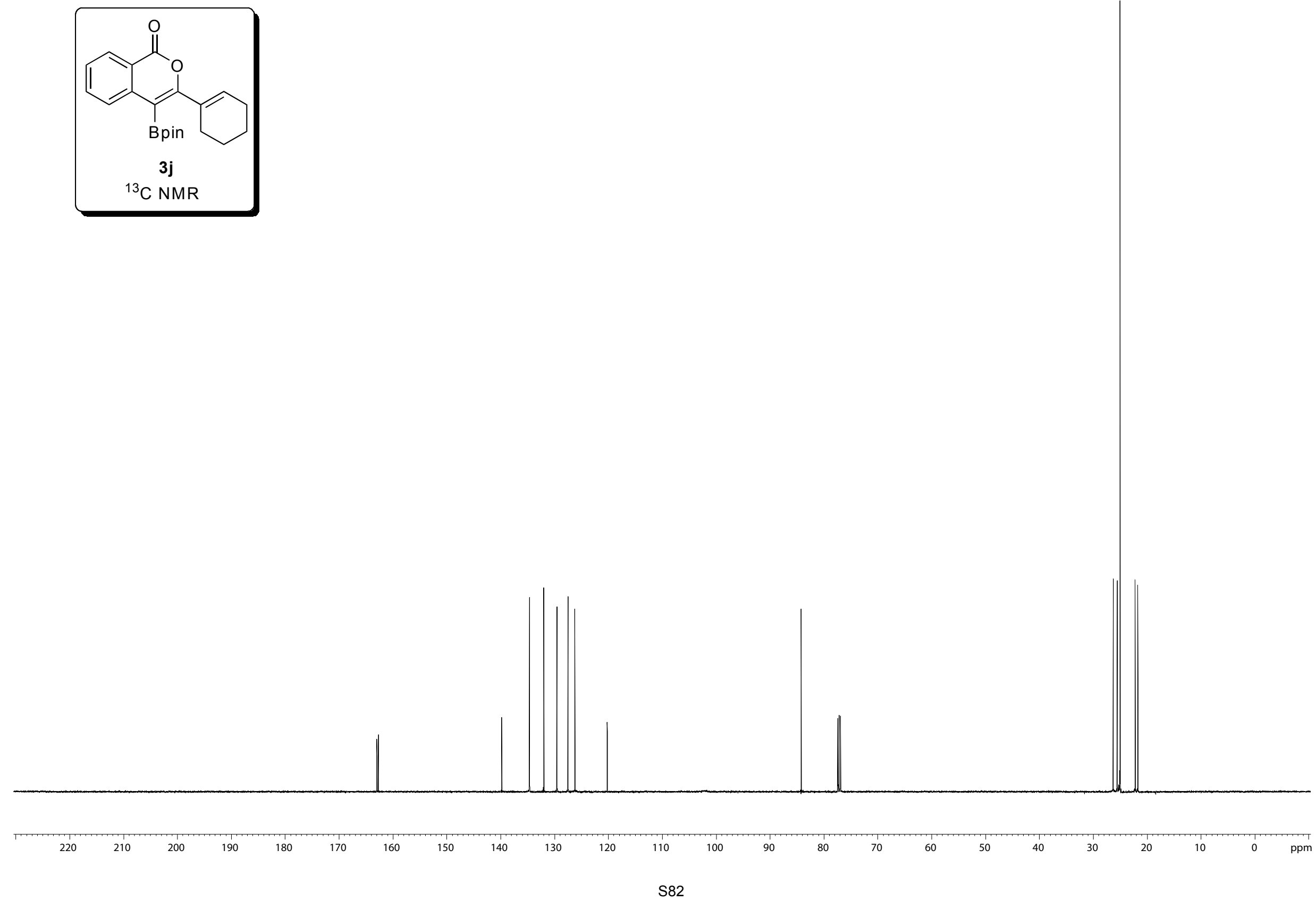


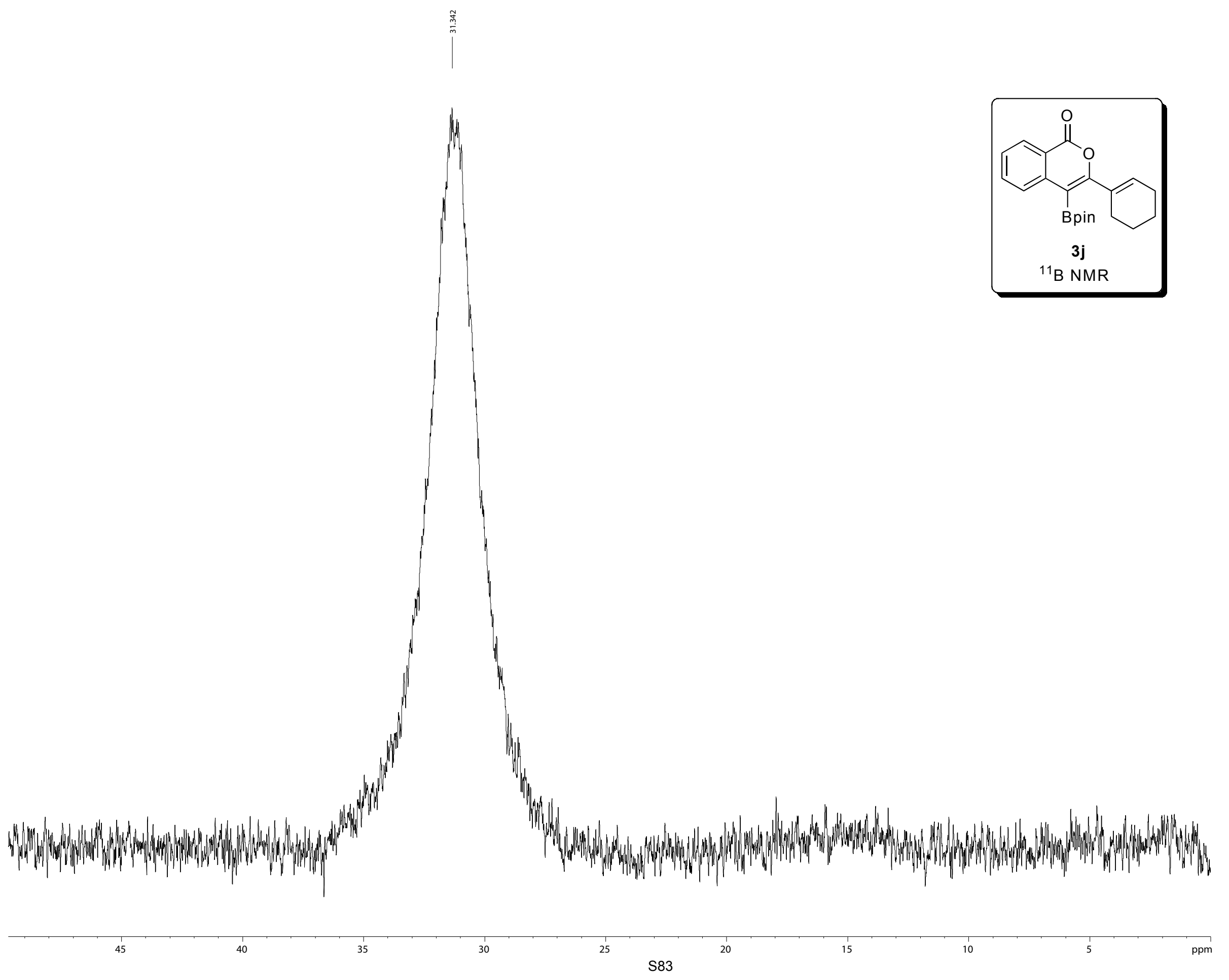




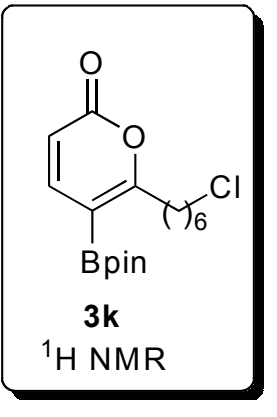

Nin

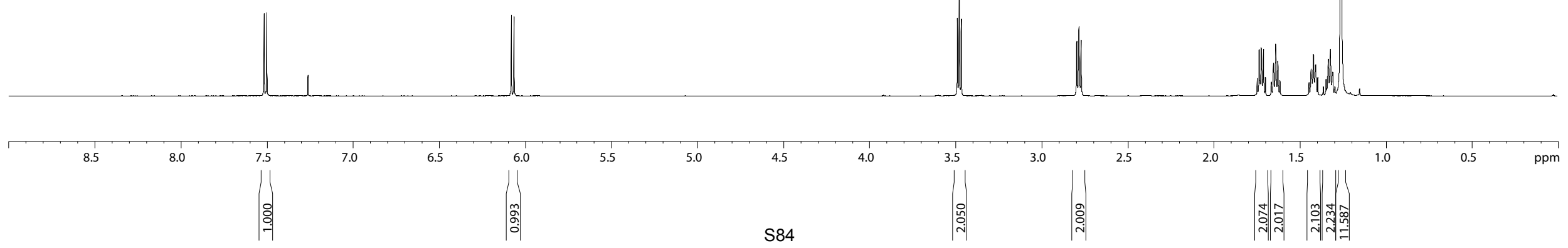




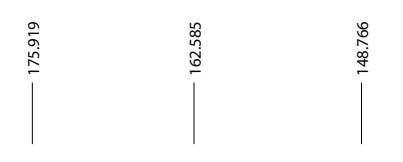
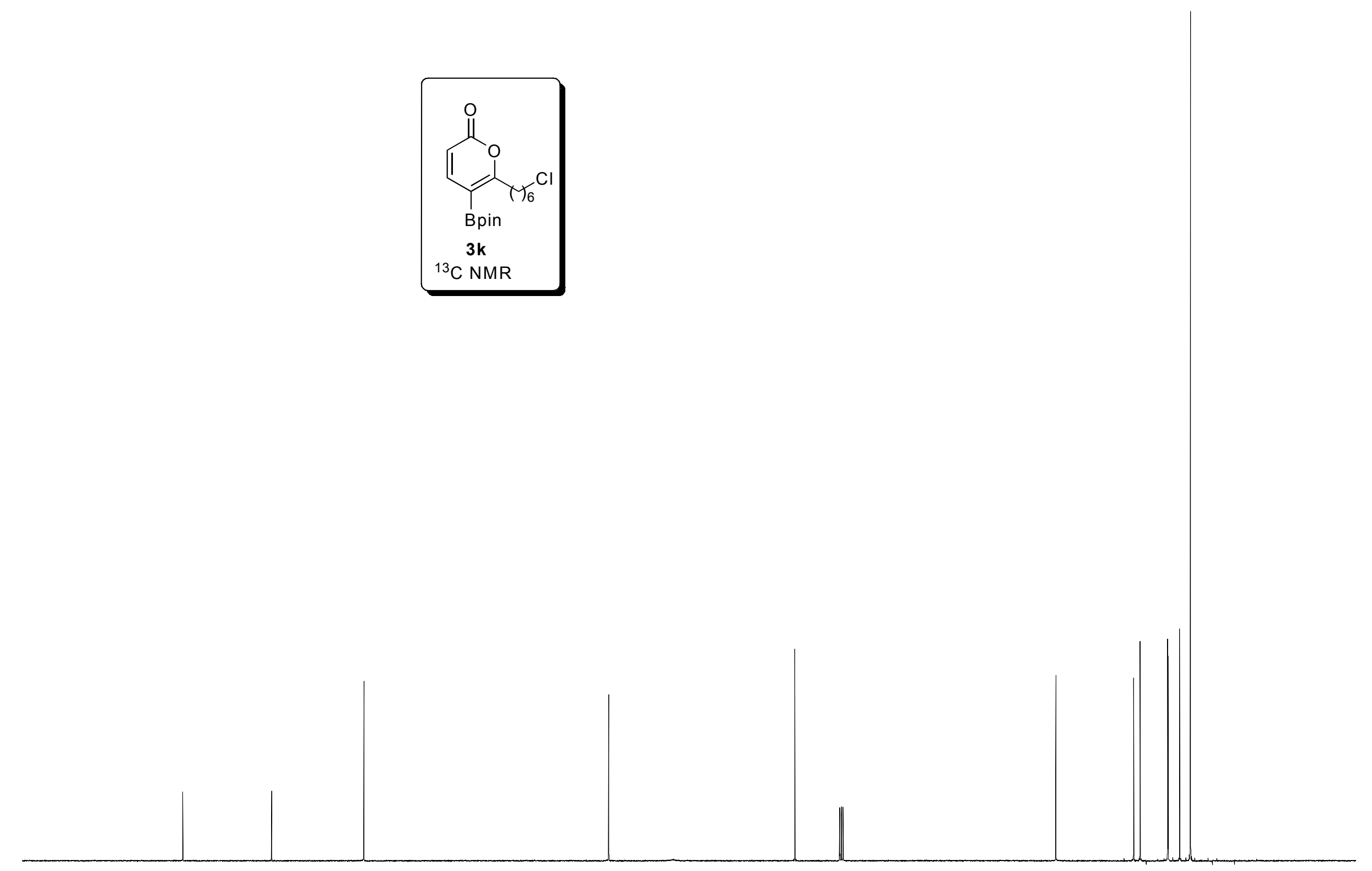

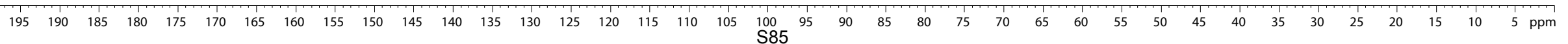




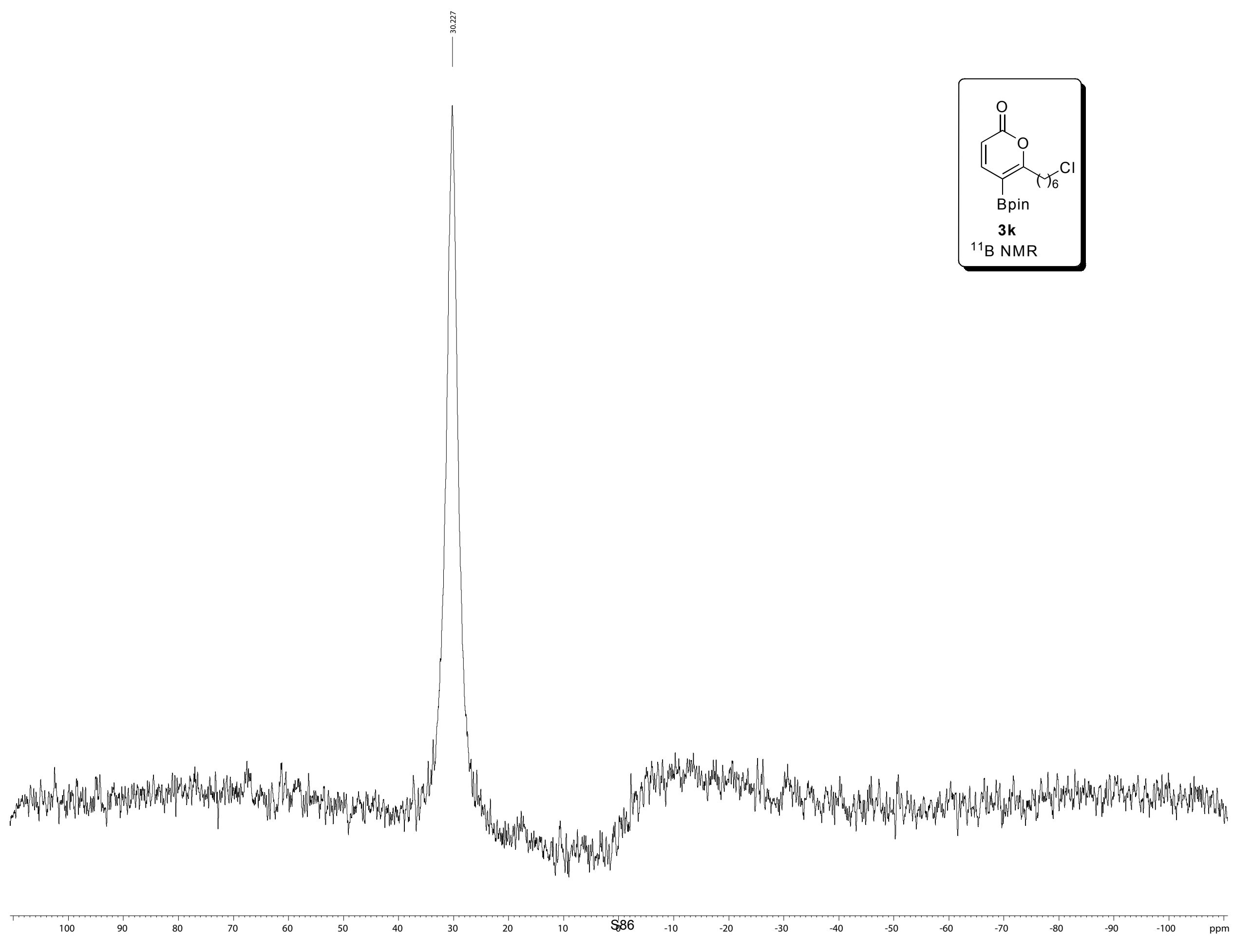



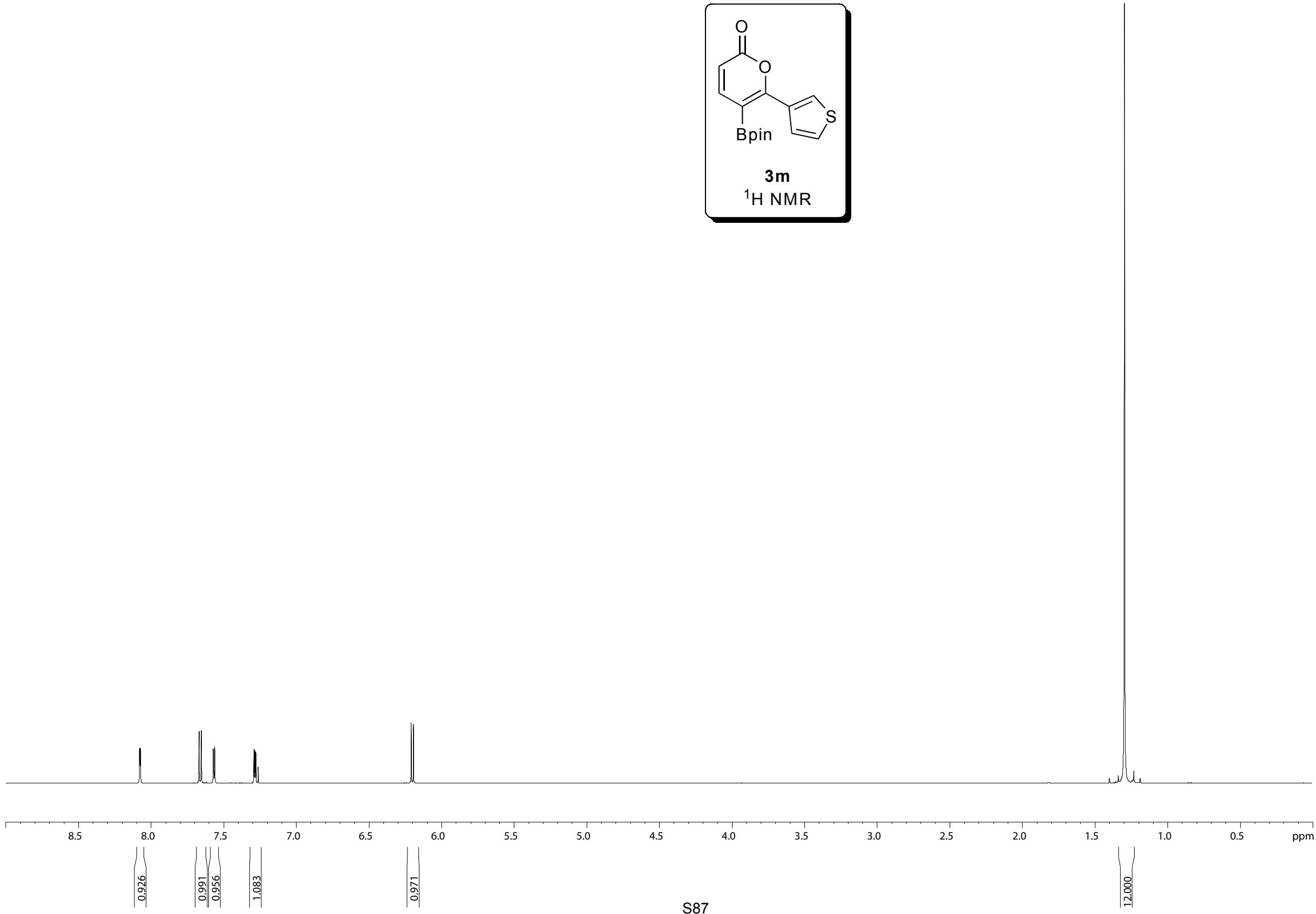

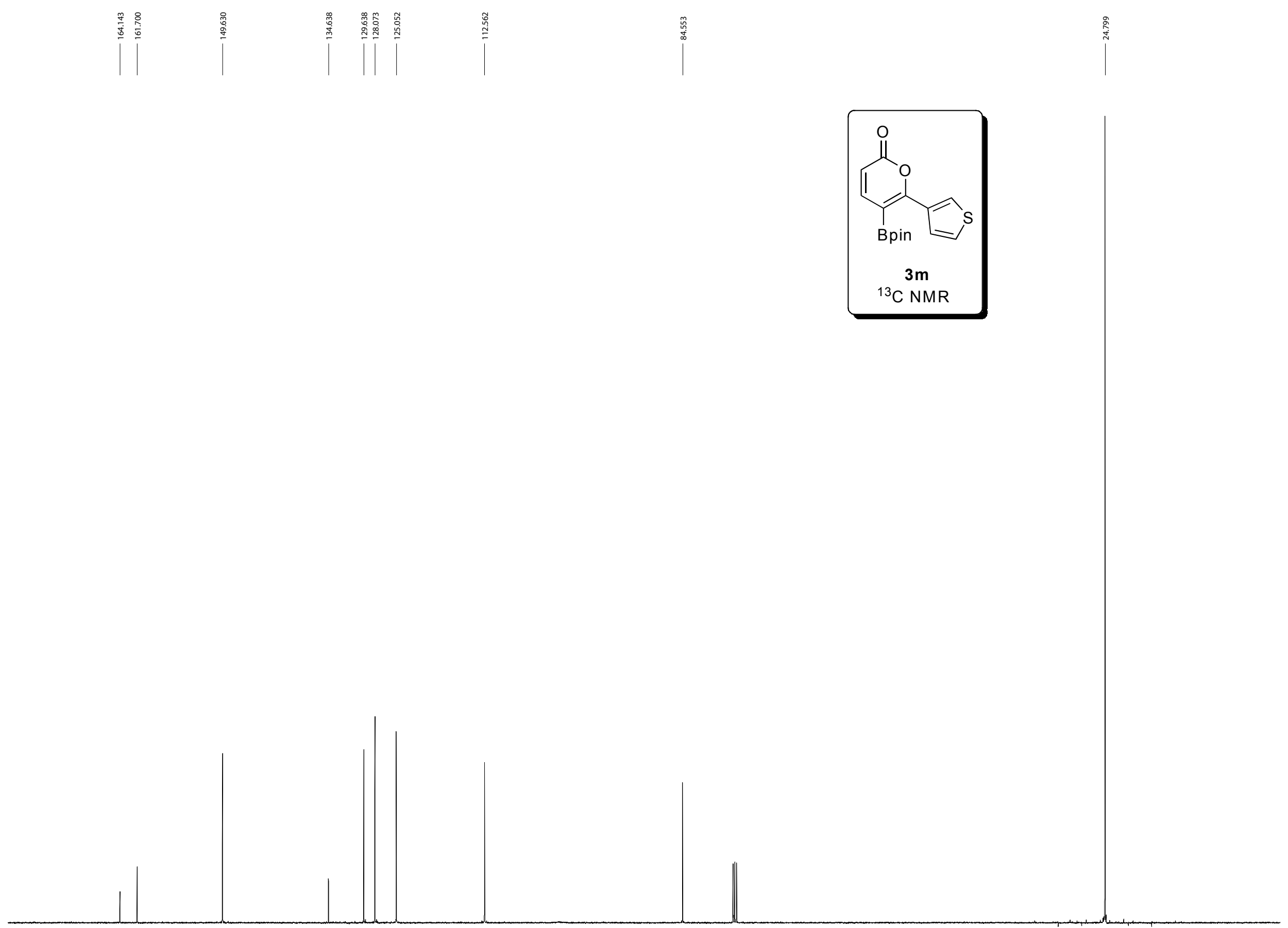


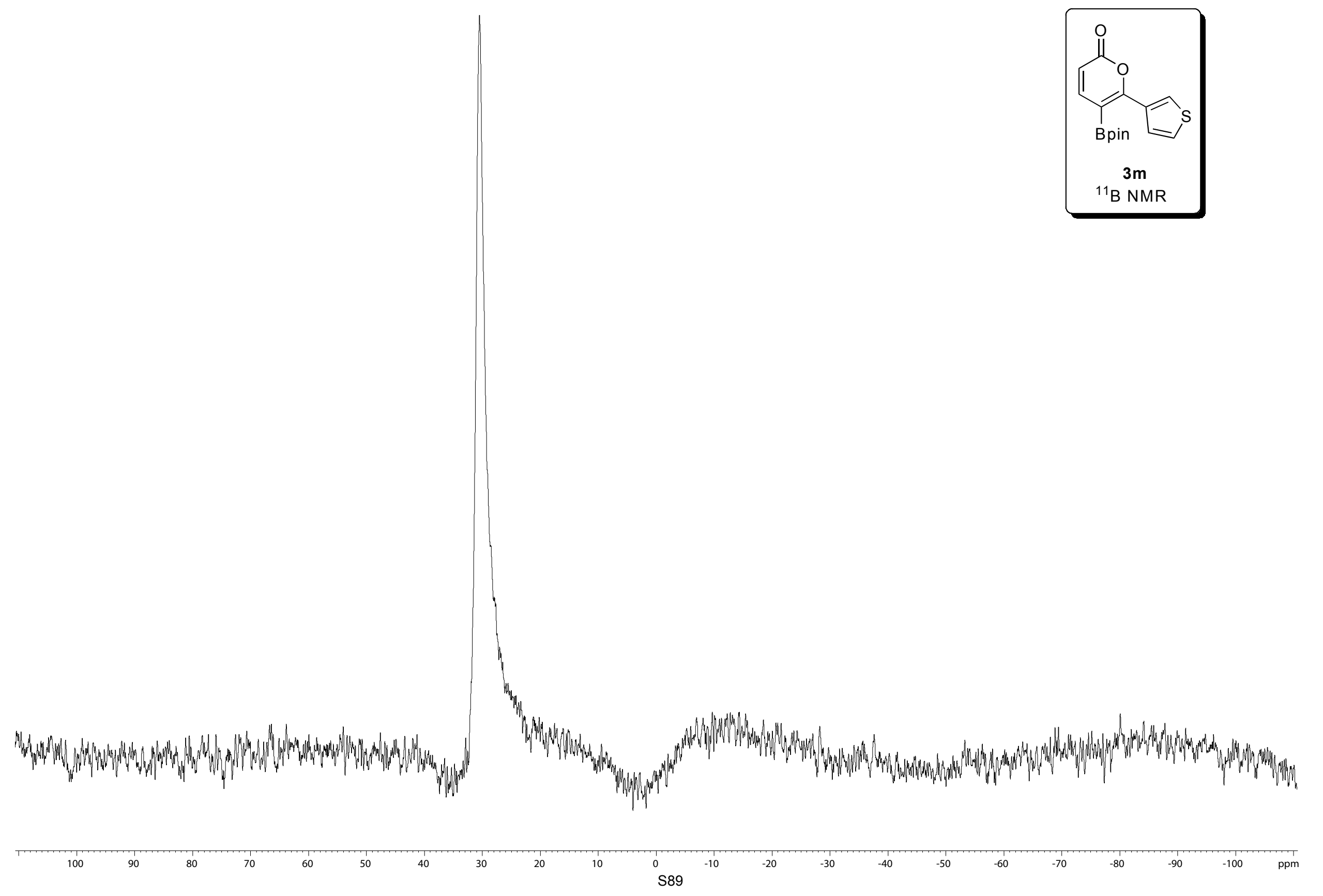



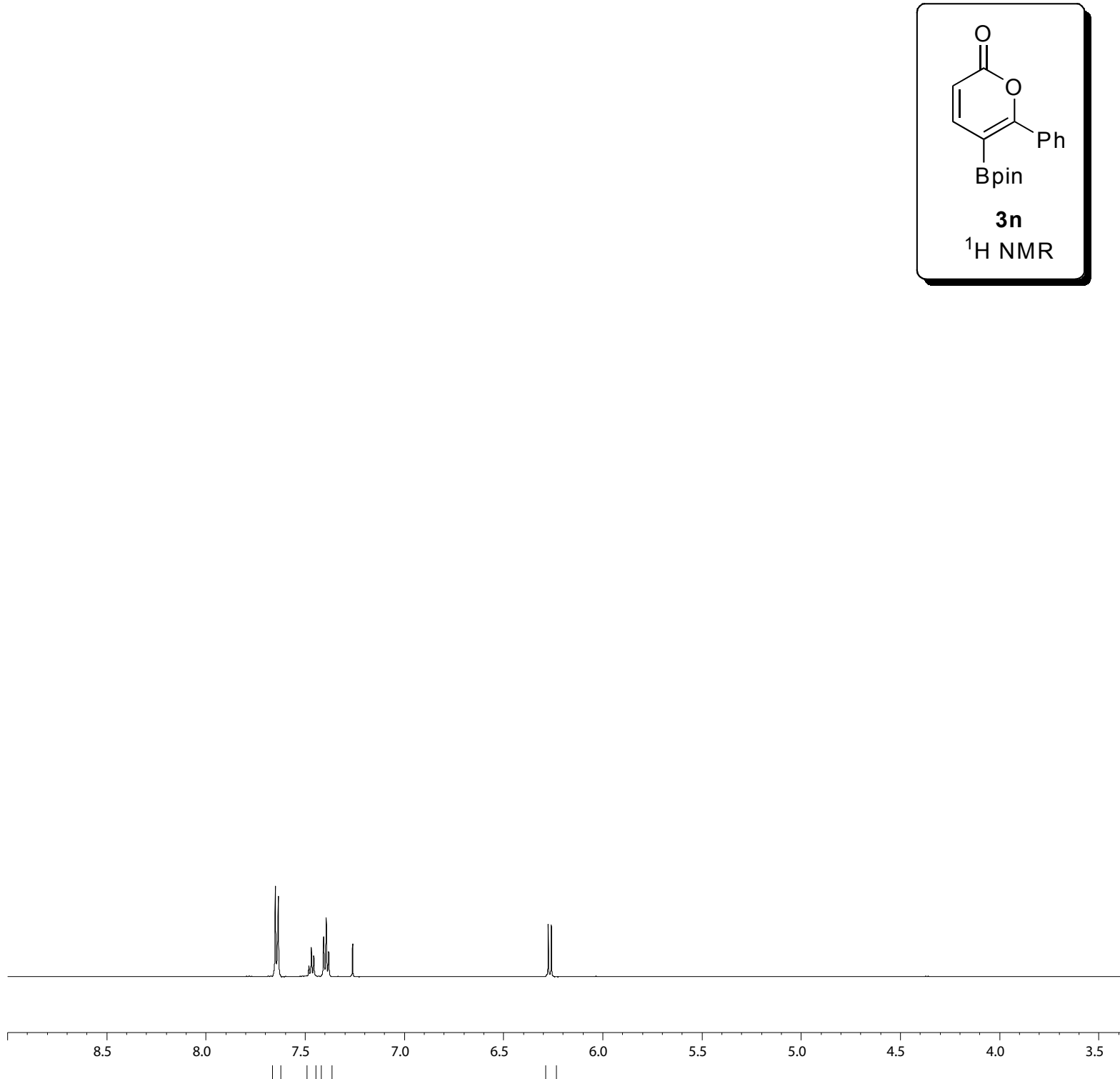
圈 


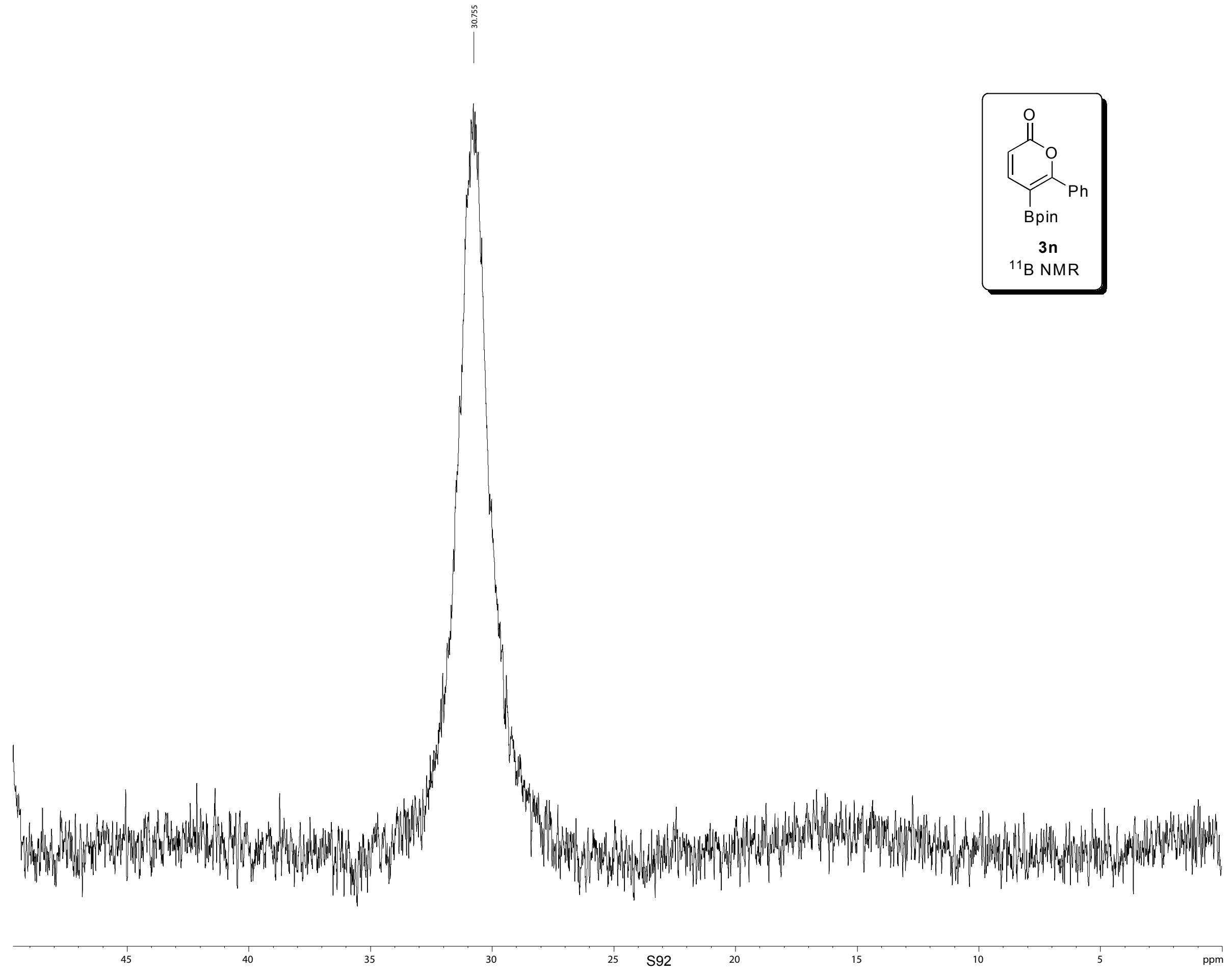



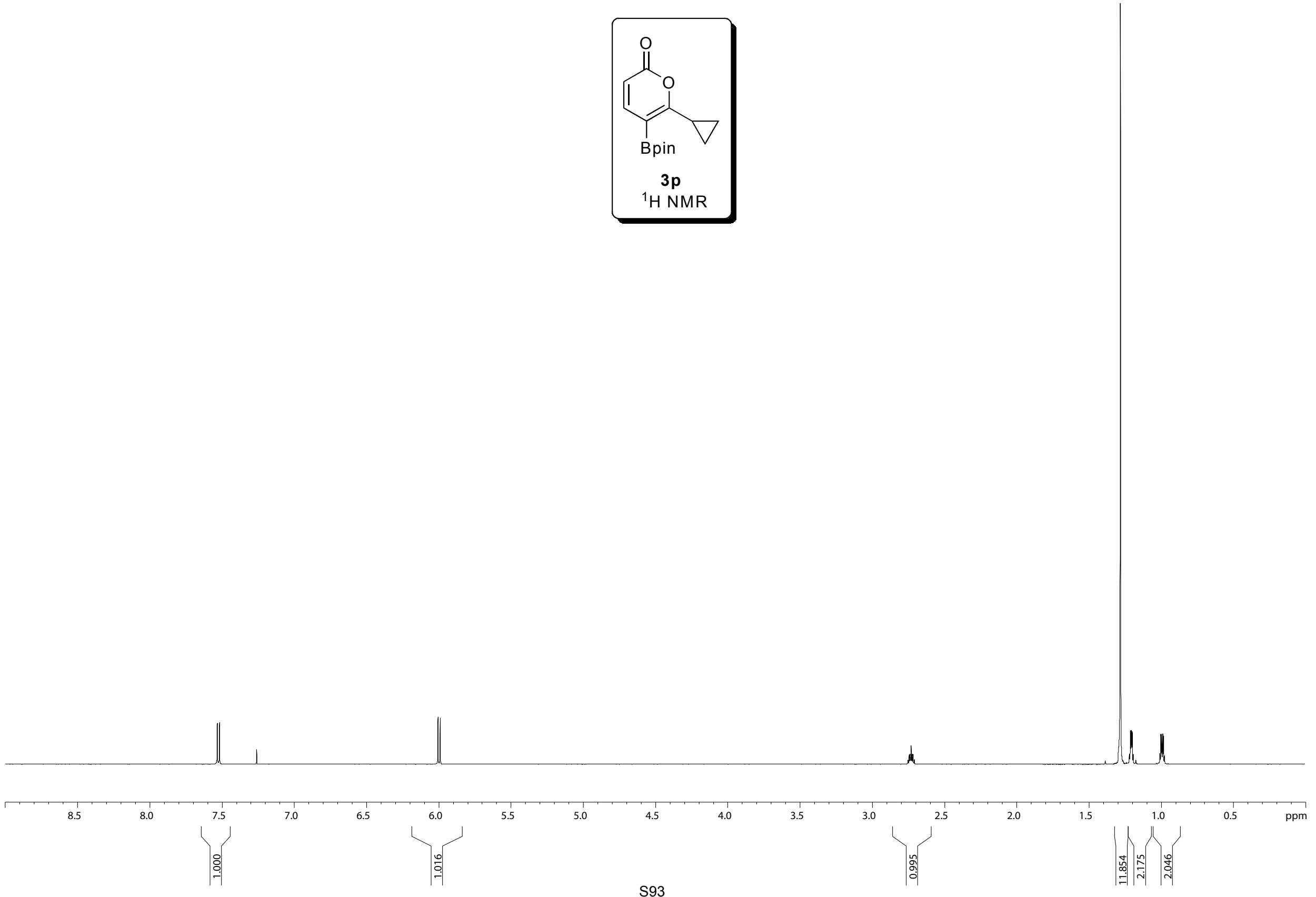


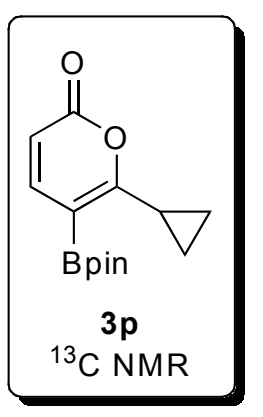




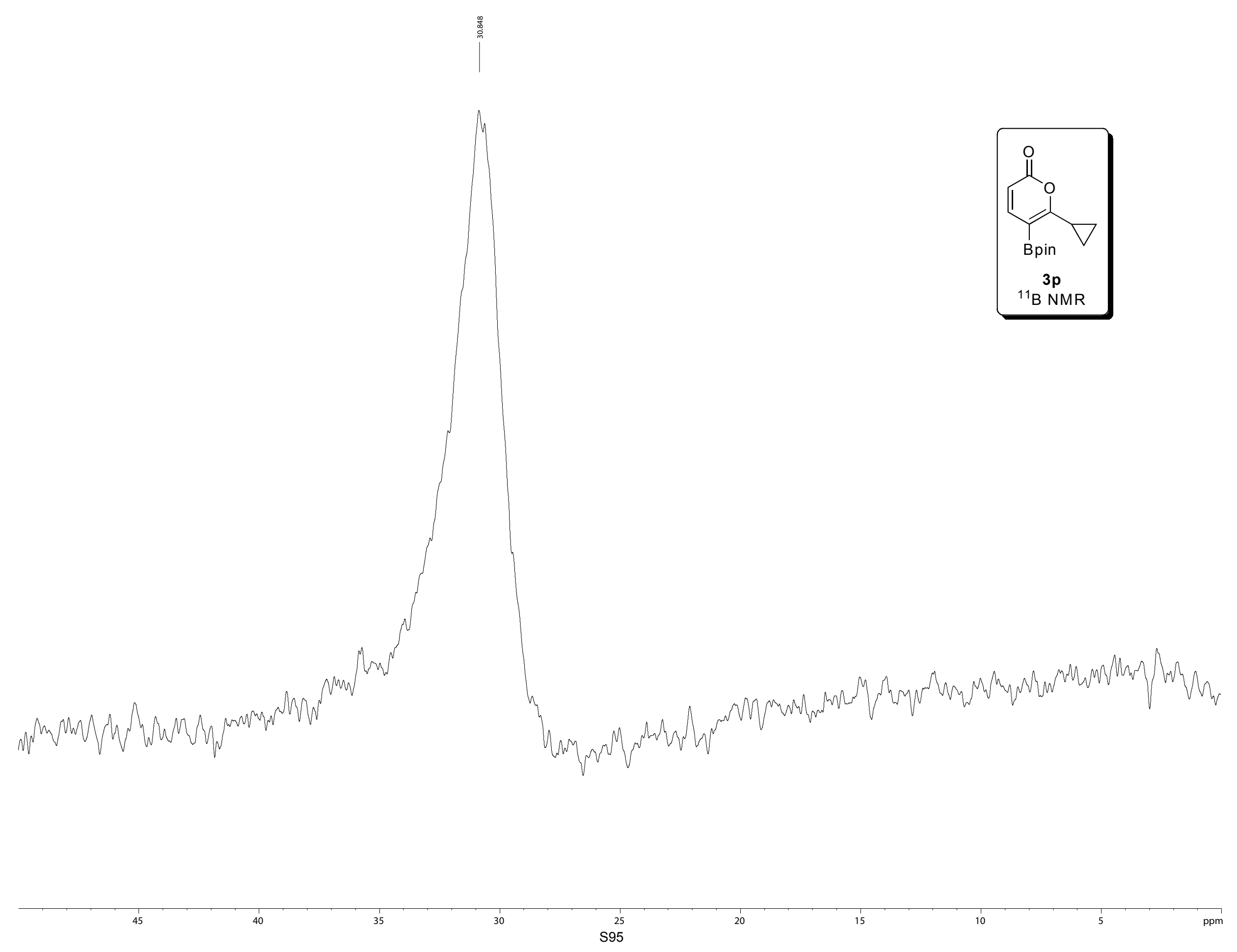



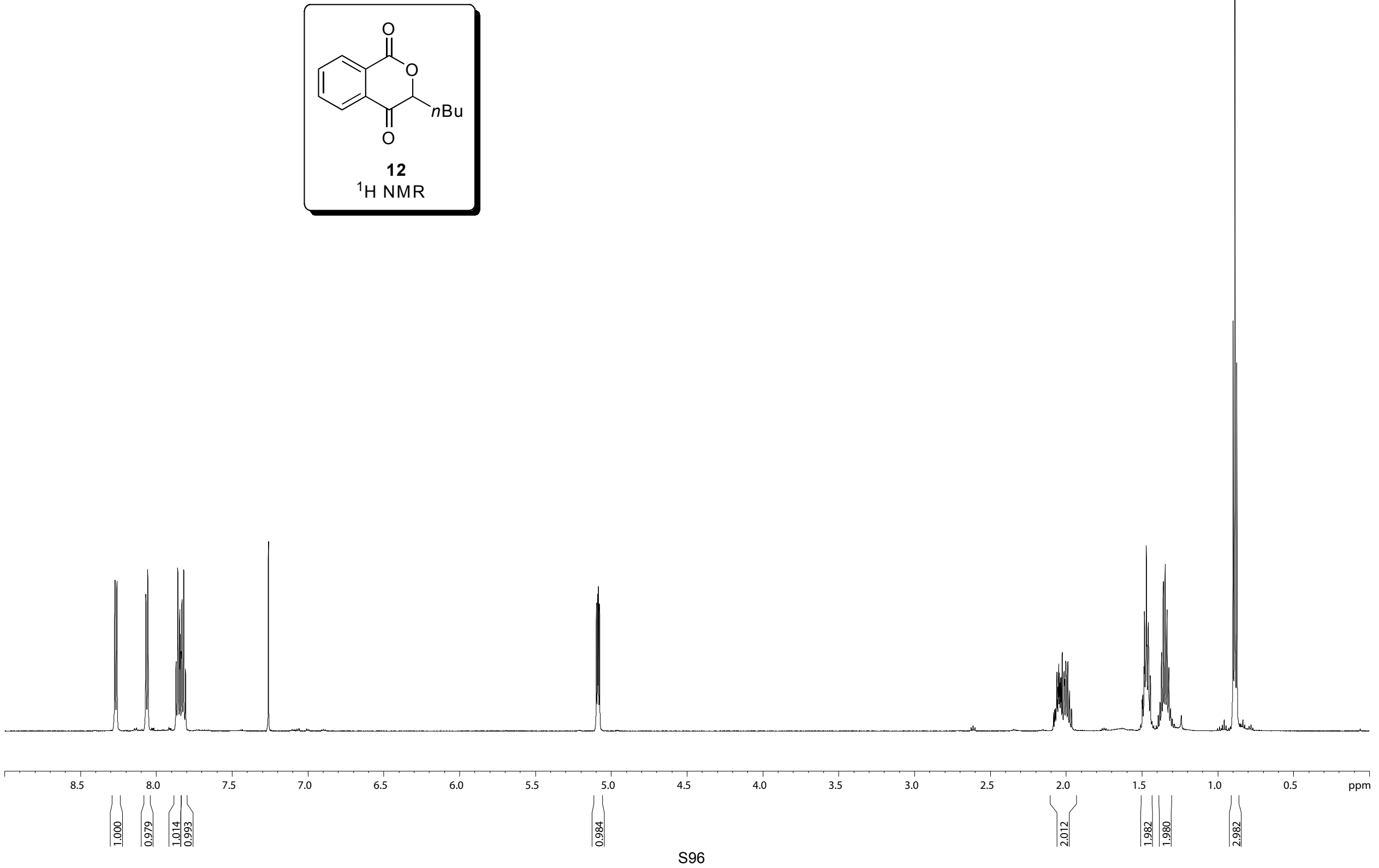

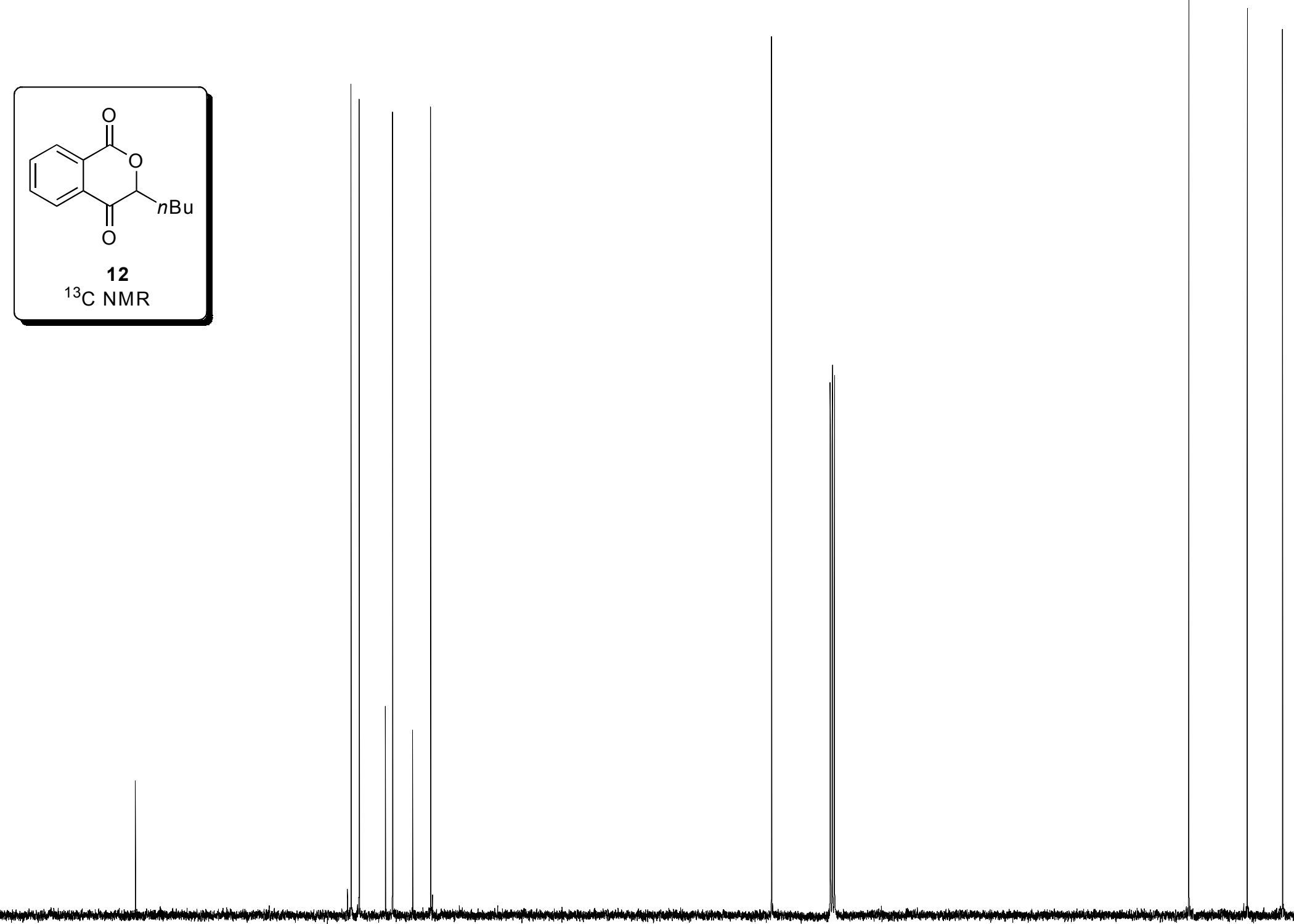

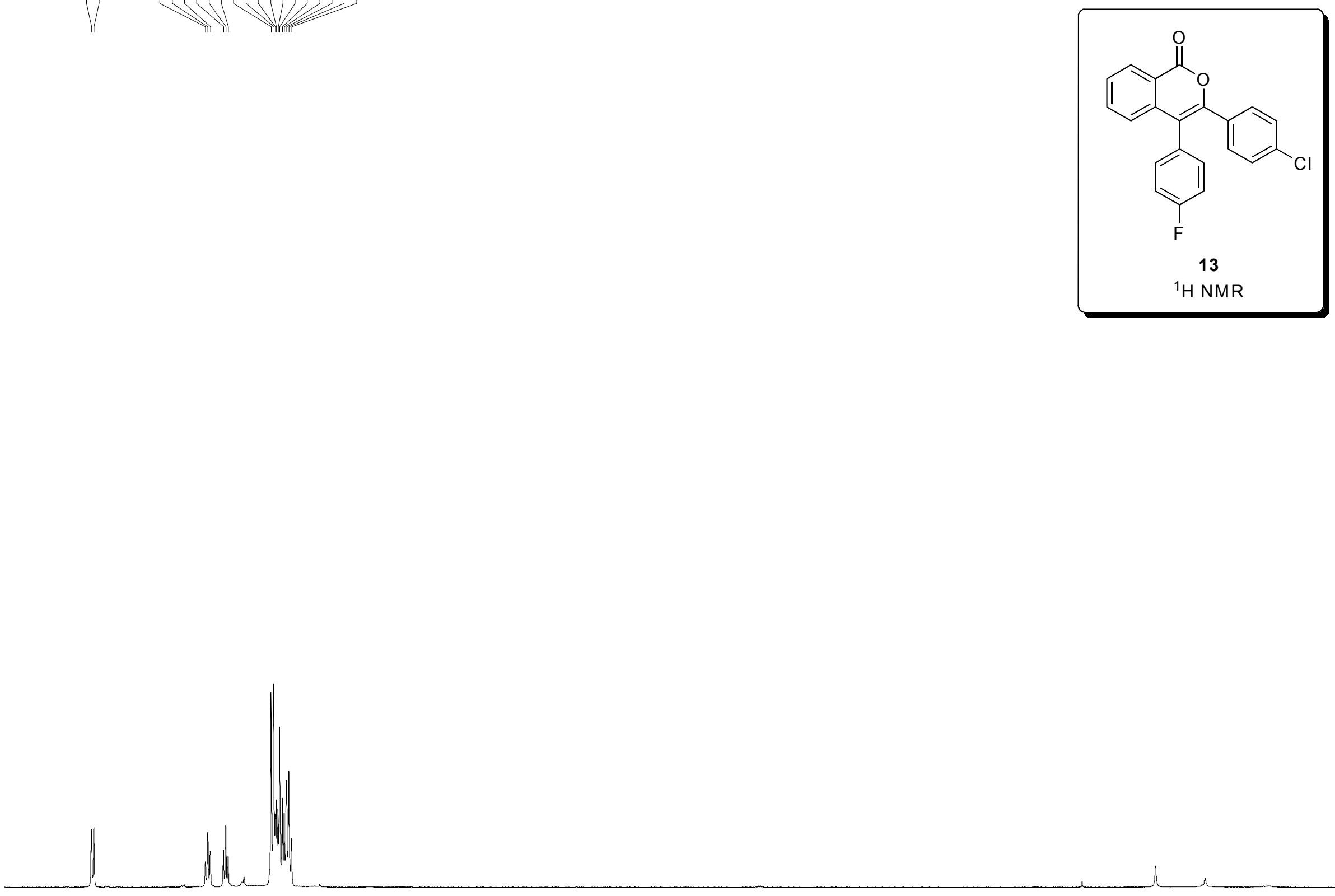

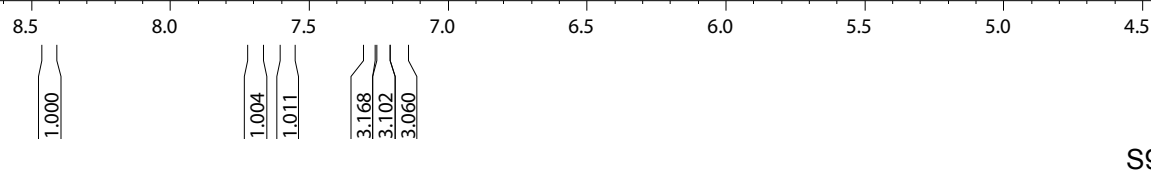




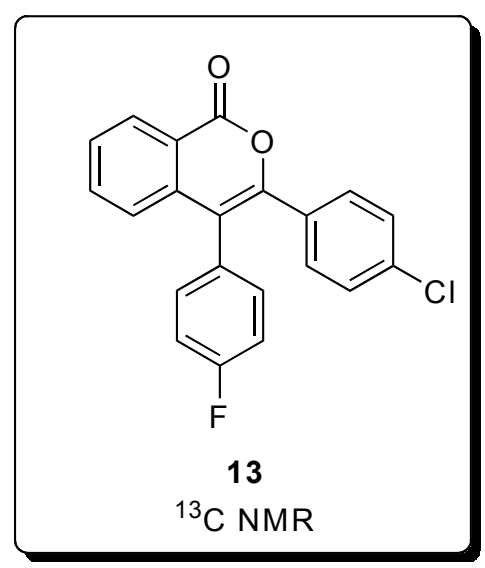




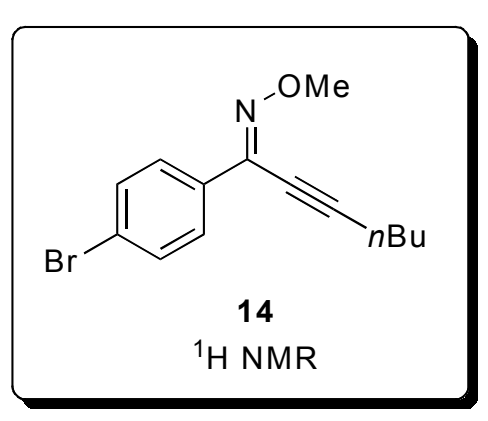

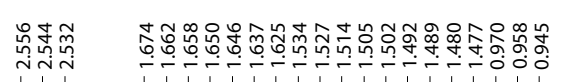

V

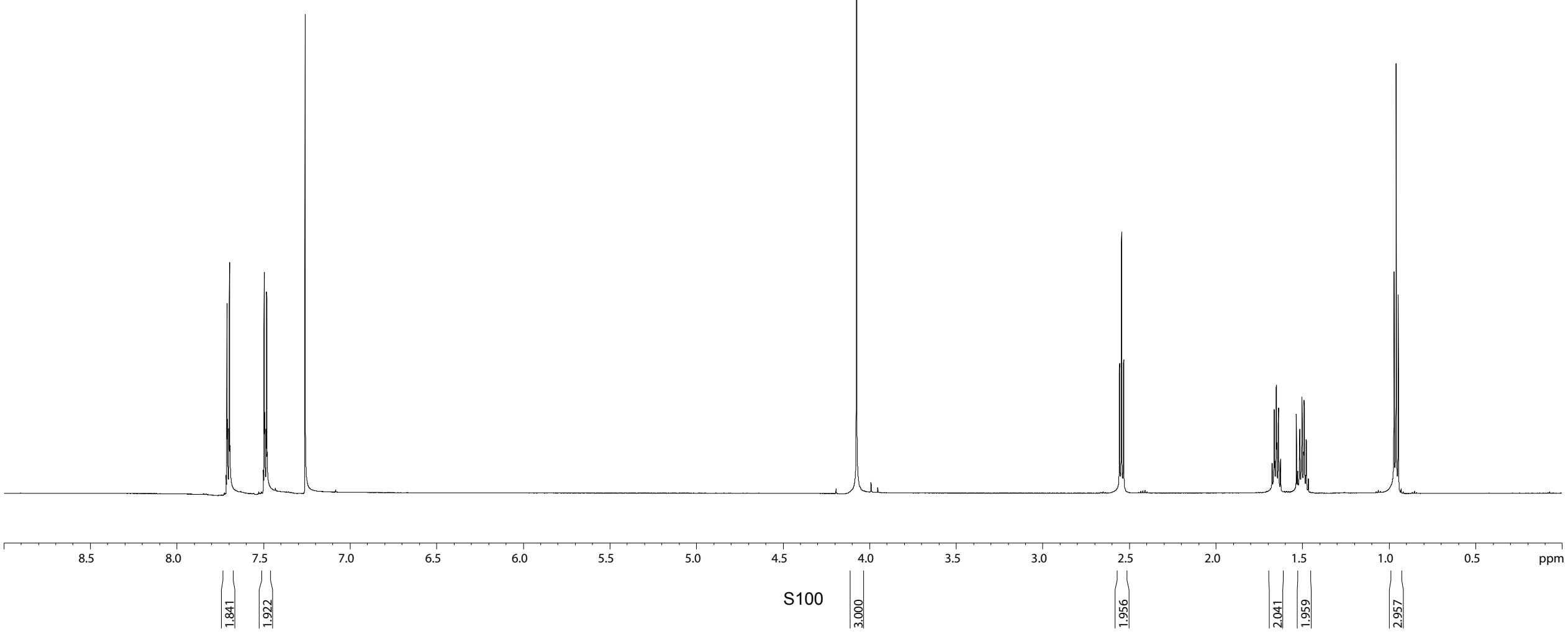




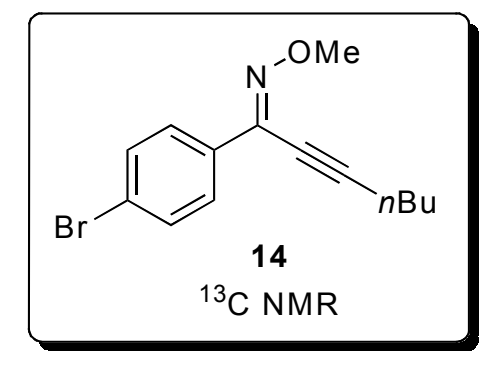

${ }^{14}$

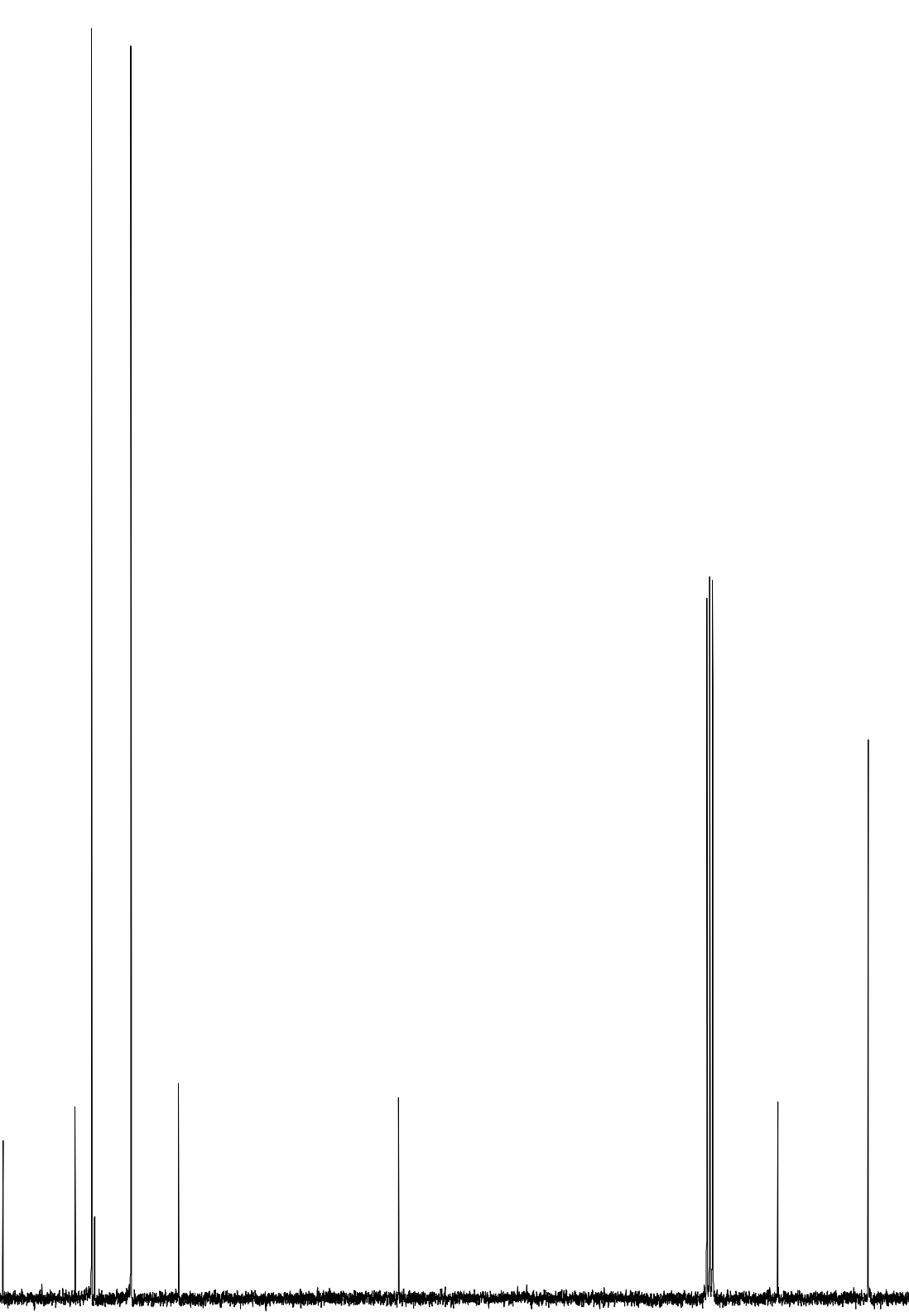



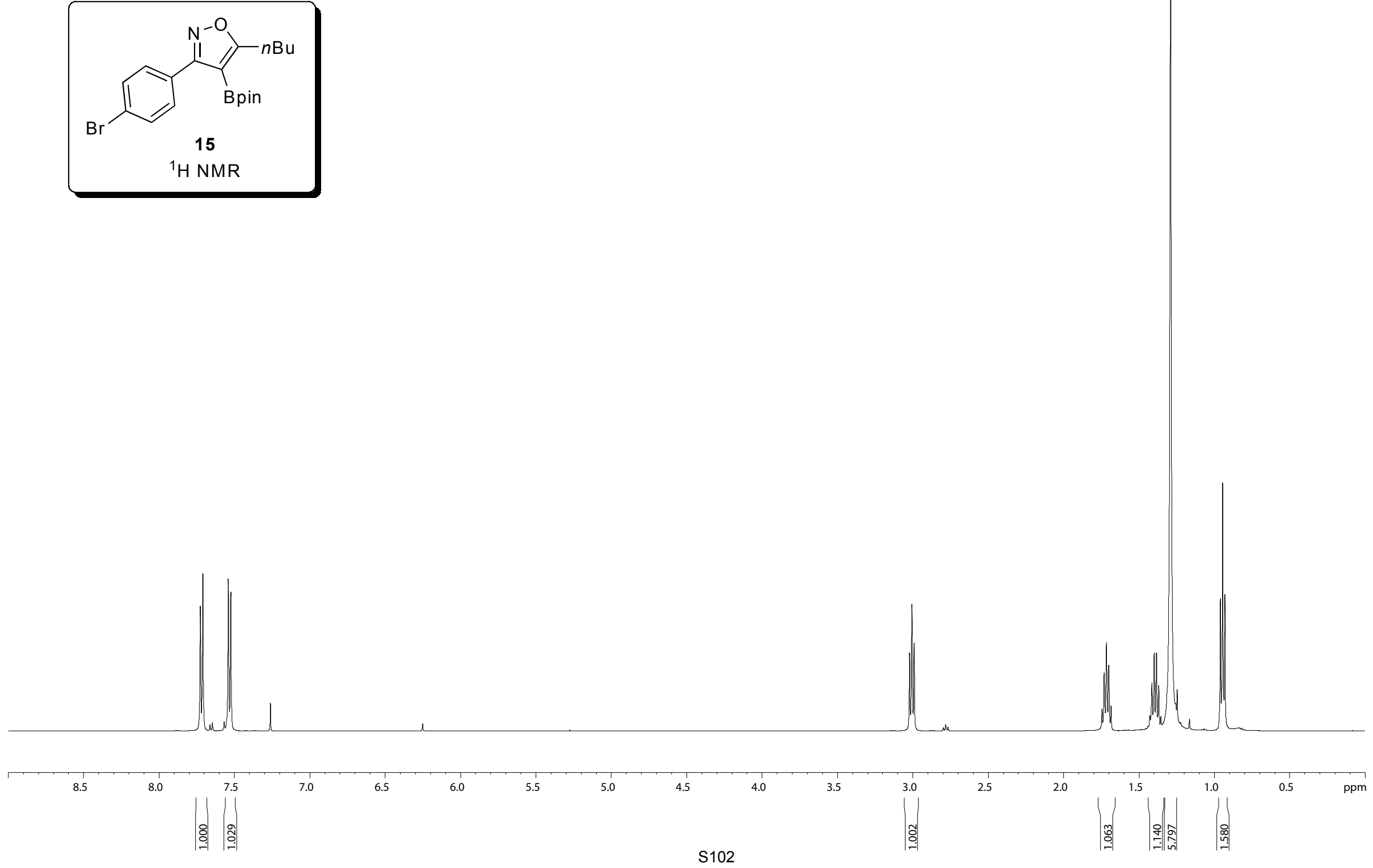


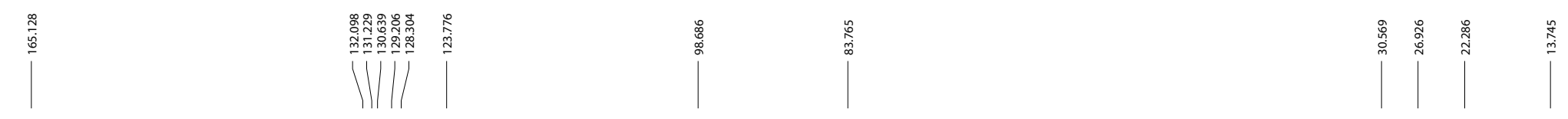
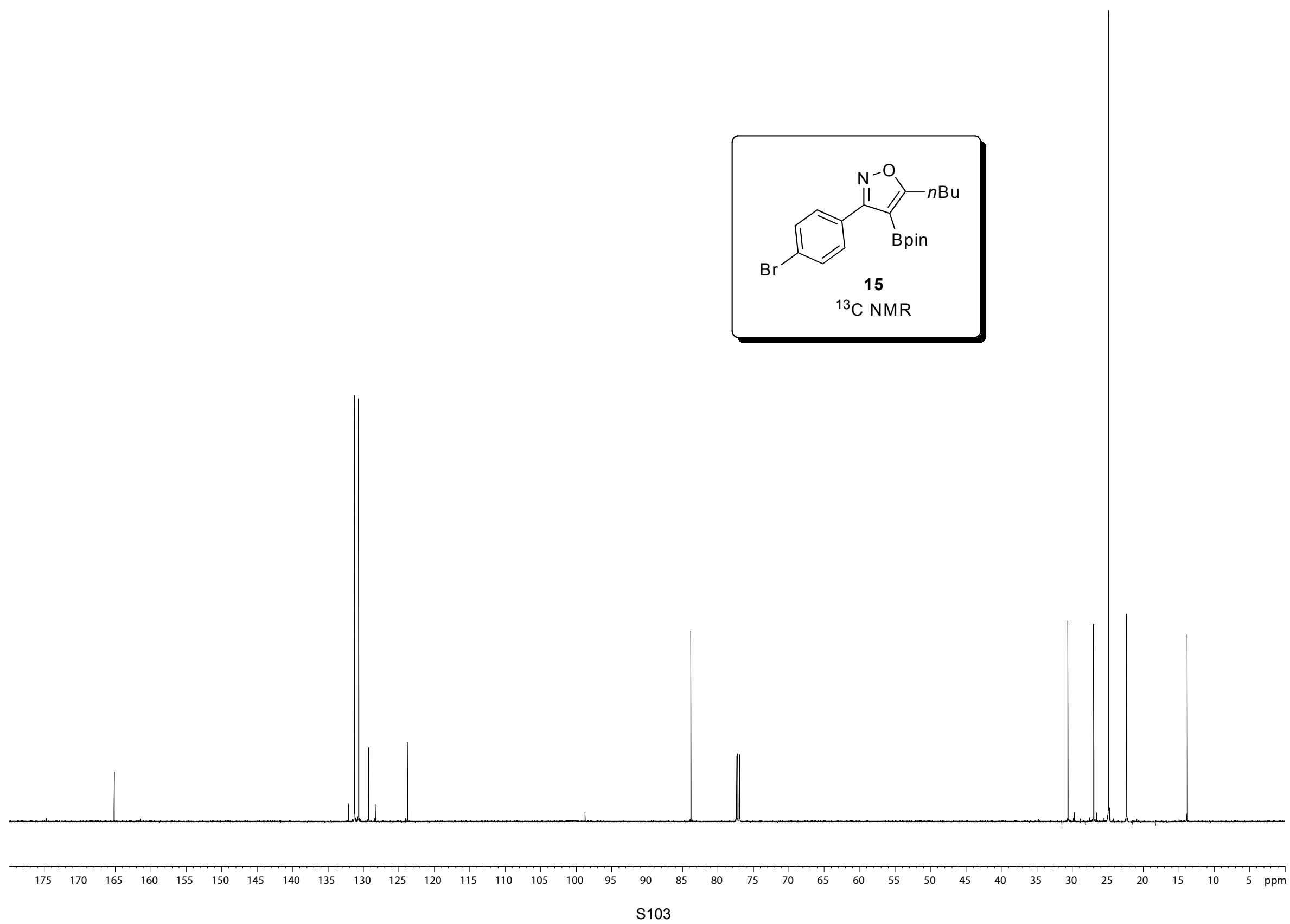


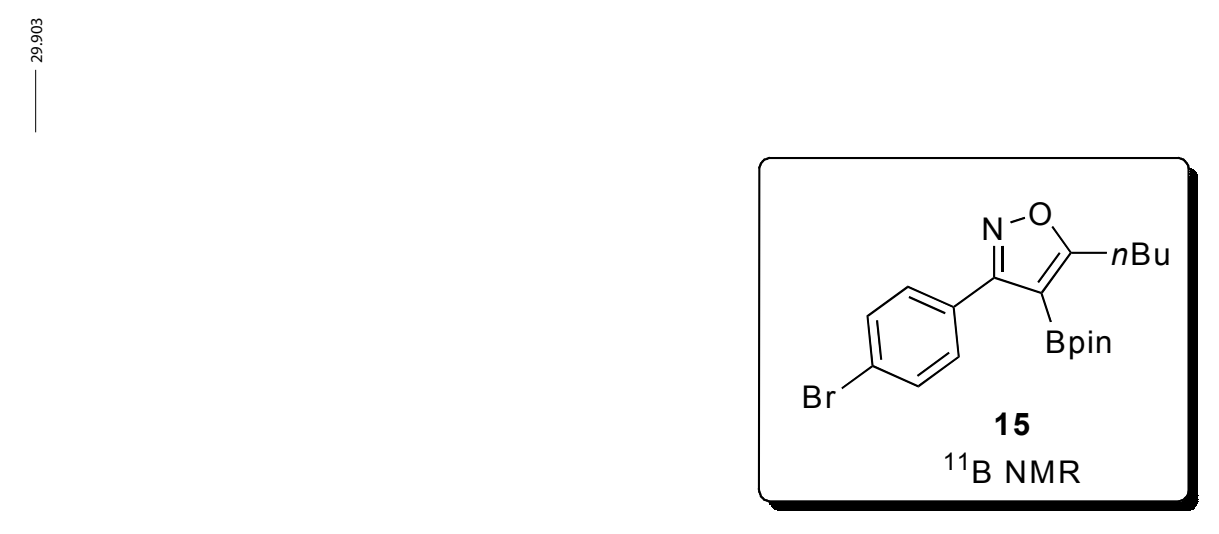

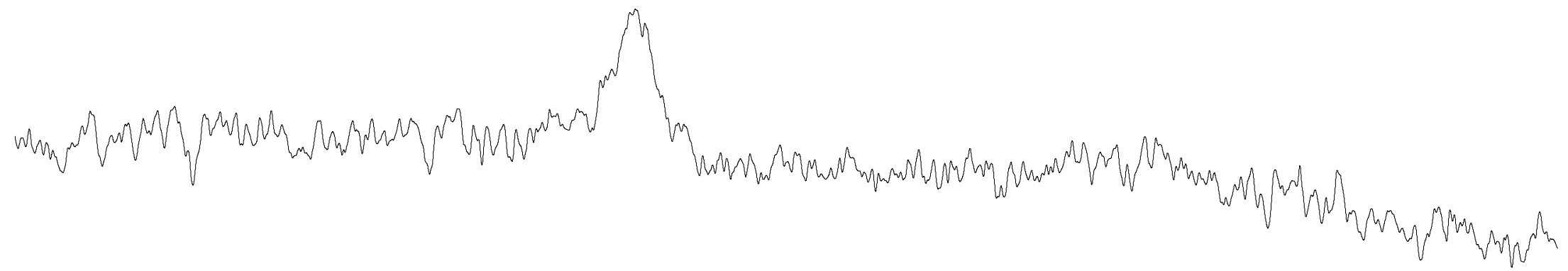




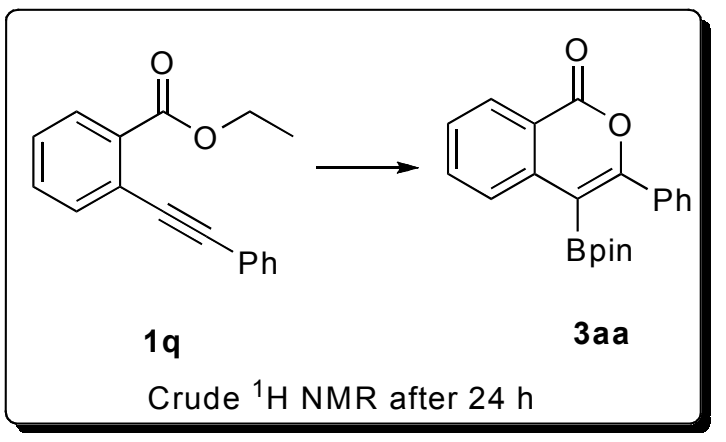

85

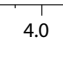

S105

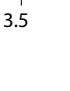

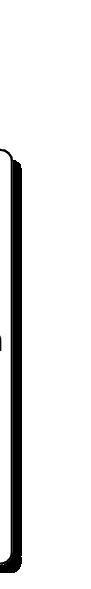
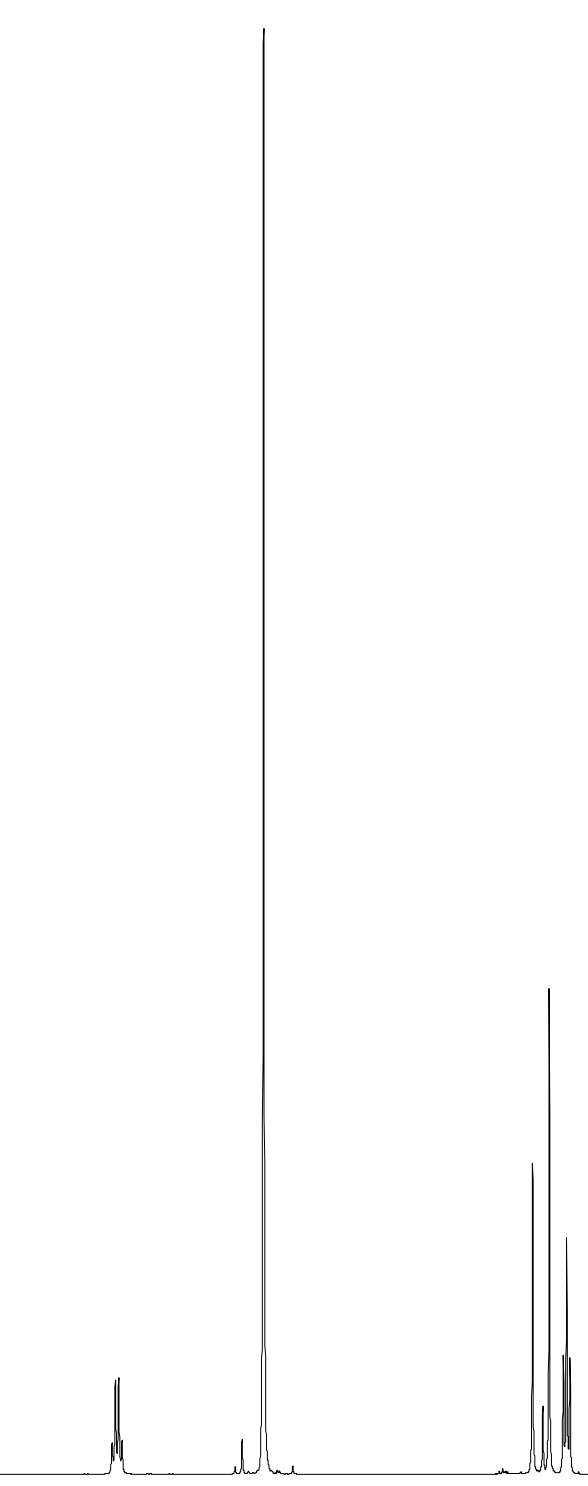

-




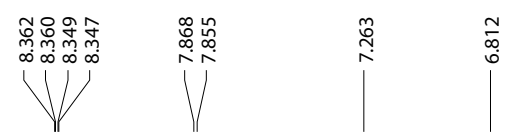

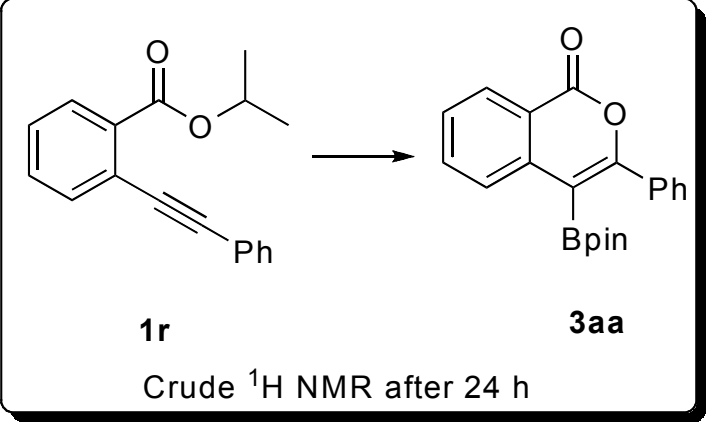

Crude ${ }^{1} \mathrm{H}$ NMR after $24 \mathrm{~h}$

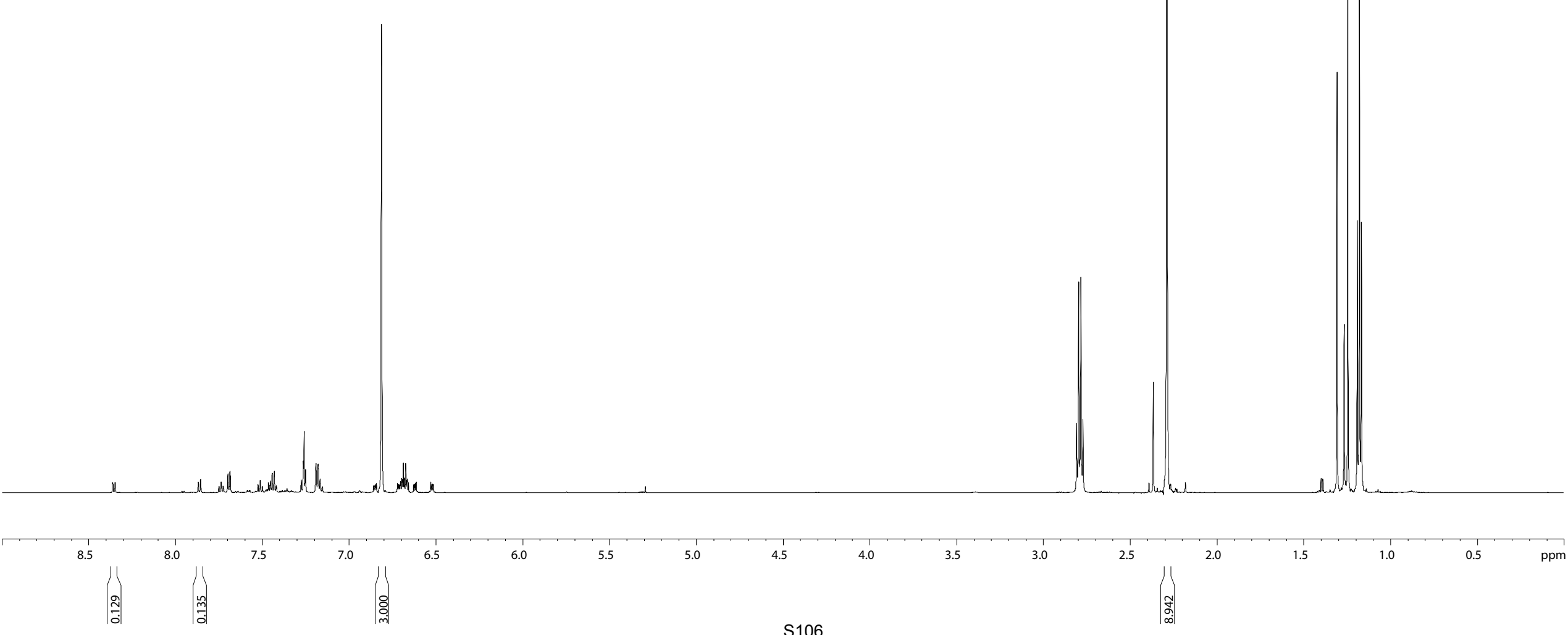



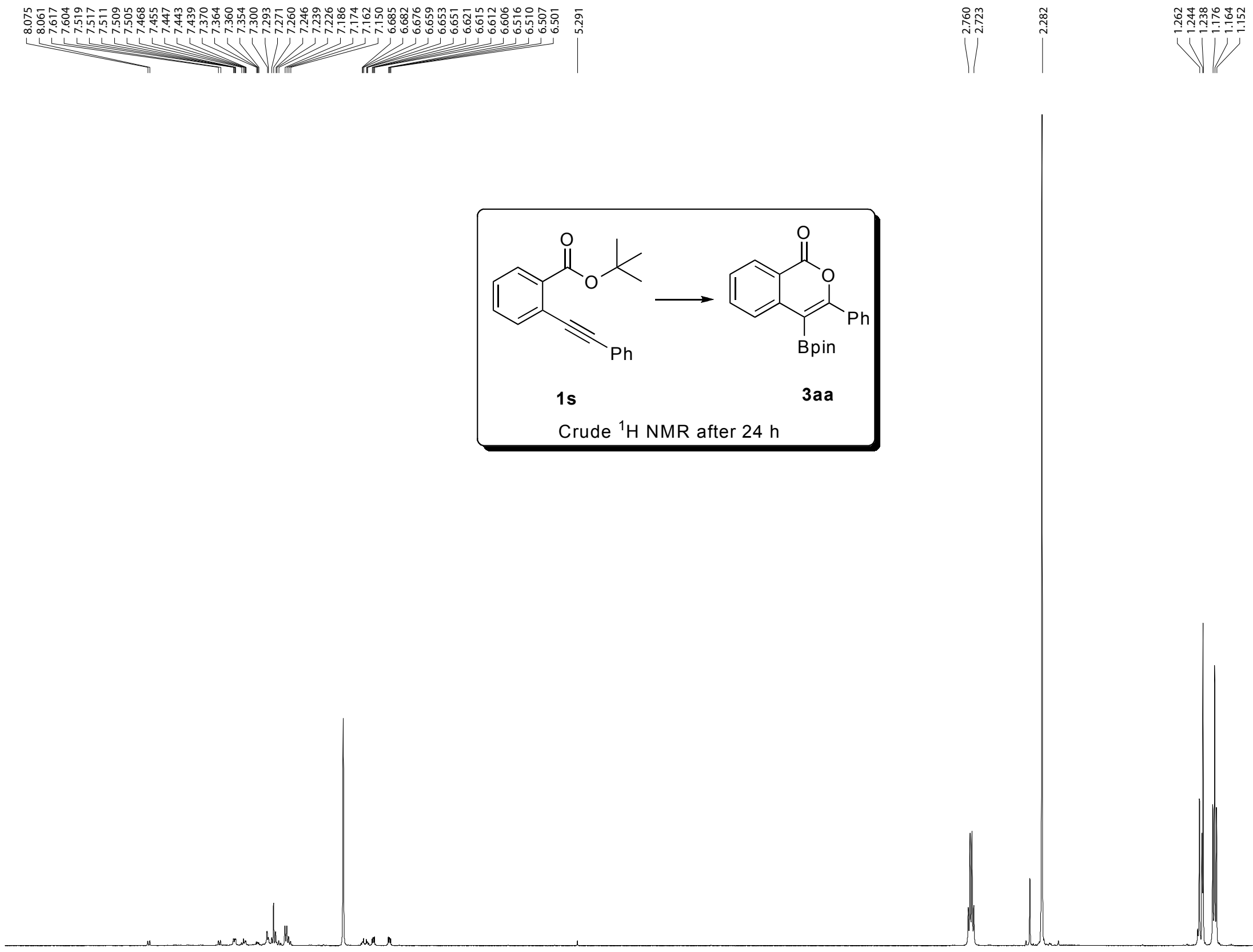

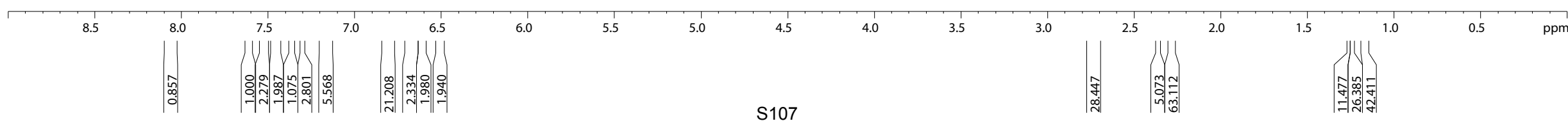



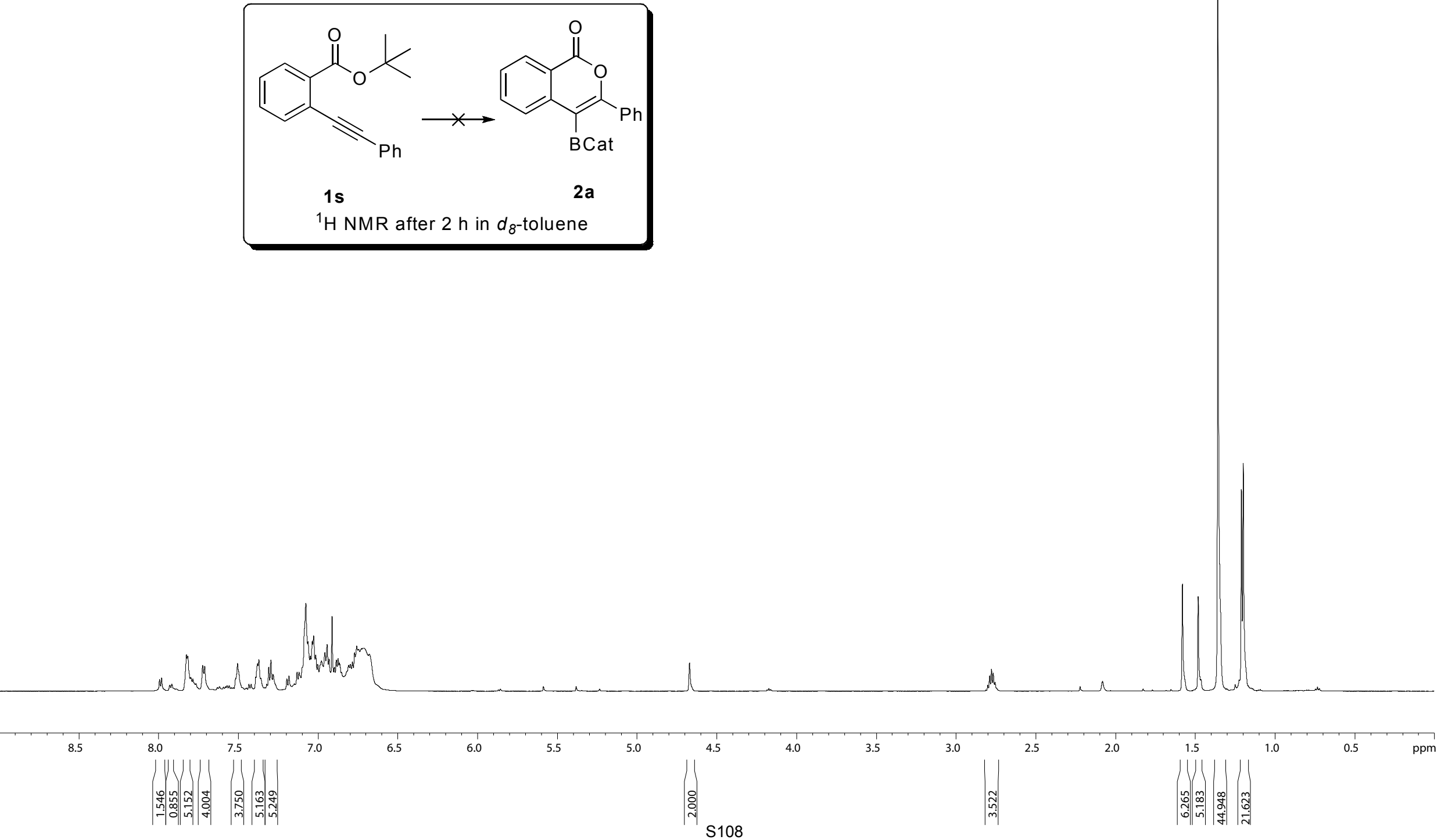


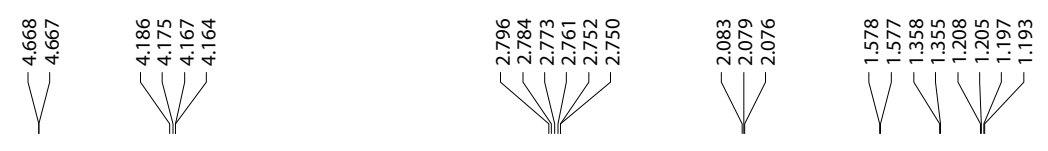
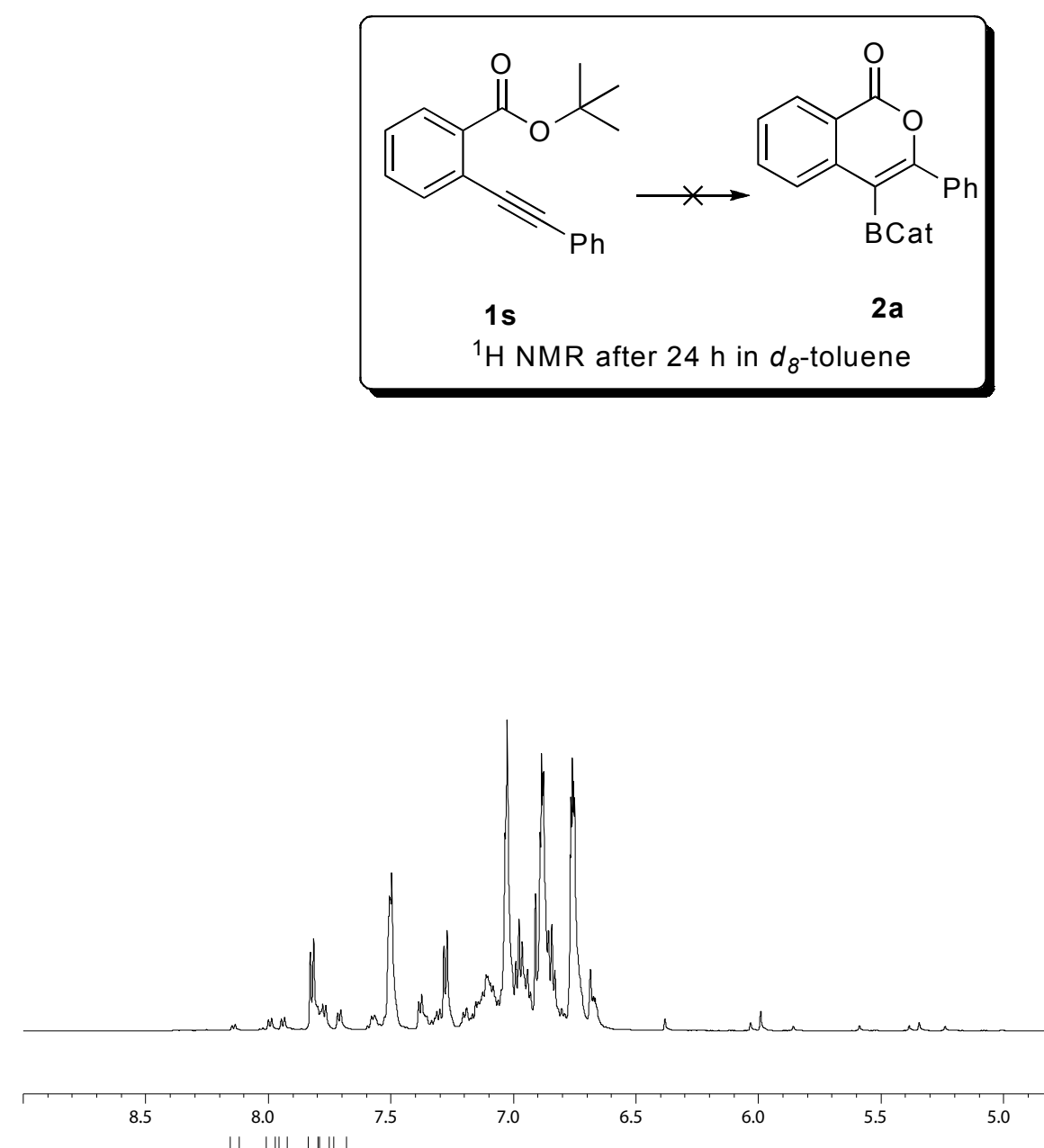

\%

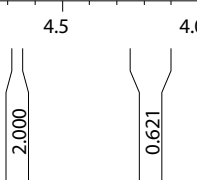

